UNIVERSIDADE DE SÃO PAULO

FACULDADE DE ECONOMIA, ADMINISTRAÇÃO E CONTABILIDADE

DEPARTAMENTO DE ECONOMIA

PROGRAMA DE PÓS-GRADUAÇÃO EM ECONOMIA

ESSAYS IN POLITICAL ECONOMY

ENSAIOS EM ECONOMIA POLÍTICA

Thomaz Mingatos Fernandes Gemignani

Orientador: Prof. Dr. Ricardo de Abreu Madeira

SÃO PAULO 
Prof. Dr. Marco Antonio Zago

Reitor da Universidade de São Paulo

Prof. Dr. Adalberto Américo Fischmann

Diretor da Faculdade de Economia, Administração e Contabilidade

Prof. Dr. Hélio Nogueira da Cruz

Chefe do Departamento de Economia

Prof. Dr. Márcio Issao Nakane

Coordenador do Programa de Pós-Graduação em Economia 
ESSAYS IN POLITICAL ECONOMY

\section{ENSAIOS EM ECONOMIA POLÍTICA}

Tese apresentada ao Departamento de Economia da Faculdade de Economia, Administração e Contabilidade da Universidade de São Paulo como requisito parcial para a obtenção do título de Doutor em Ciências.

Orientador: Prof. Dr. Ricardo de Abreu Madeira

Versão Corrigida

(Versão Original disponível na Faculdade de Economia, Administração e Contabilidade)

SÃO PAULO 


\section{FICHA CATALOGRÁFICA}

Elaborada pela Seção de Processamento Técnico do SBD/FEA/USP

Gemignani, Thomaz Mingatos Fernandes

Essays in political economy / Thomaz Mingatos Fernandes Gemignani. - São Paulo, 2015.

$173 \mathrm{p}$.

Tese (Doutorado) - Universidade de São Paulo, 2015.

Orientador: Ricardo de Abreu Madeira.

1. Economia política 2. Reeleição 3. Clientelismo 4. Filiação partidária 5. Econometria I. Universidade de São Paulo. Faculdade de Economia, Administração e Contabilidade. II. Título.

$$
\text { CDD }-330
$$


Aos meus pais, Silvio e Suzana. 


\section{AGRADECIMENTOS}

Em primeiro lugar, agradeço à minha família pela motivação, pelo apoio incondicional (de diversas naturezas) e por todo o empenho em minha formação. Agradeço também à minha namorada, Louise, por sempre tornar os meus dias mais ensolarados. O carinho e a compreensão de todos vocês foram, sem dúvida, imprescindíveis ao término desta jornada.

Agradeço ao meu orientador, Ricardo Madeira, pelo apoio, pela paciência e por toda a confiança em mim depositada ao longo desses anos. Agradeço ainda a todos os professores que contribuíram com a minha formação acadêmica, em particular aos professores Marcos Nakaguma, Marcos Rangel e Fernando Botelho, pela atenção e pelas valiosas sugestões a respeito deste trabalho.

Sou profundamente grato pela convivência com os meus amigos e colegas de pósgraduação, a qual foi fundamental em tornar esse período suportável. Agradeço a companhia e a amizade de Maximiliano Barbosa, Thiago Angelis, Anderson Cardoso, Antônio Bruno Morales e Sérgio Castelani. Em especial, agradeço ao Luís Meloni, à Denise Imori, e ao Eduardo Astorino pelo companheirismo e pela cooperação em toda esta empreitada.

Agradeço ao pessoal da Coordenação de Pós-Graduação do IPE e da Secretaria de Pós-Graduação da FEA pelas orientações, pela cordialidade, e pela competência. Por fim, agradeço à CAPES e ao CNPq pelo auxílio financeiro durante o programa de doutorado, e à FEA-USP por toda a infraestrutura oferecida. 
"Why is it always the innocents who suffer most, when you high lords play your game of thrones?" Lord Varys, A Game of Thrones 


\section{RESUMO}

Esta tese se divide em três partes. A primeira parte lida com a questão de que, em um ambiente político em que o desenvolvimento de uma carreira política possa envolver frequentes transições entre cargos, não se tem claro como a ocupação de uma dada posição eletiva pode fundamentalmente influenciar o desempenho eleitoral subsequente e a formação de uma carreira pelos políticos. São exploradas regressões descontínuas baseadas em eleições brasileiras com o intuito de se estimar o impacto eleitoral de ser o mandatário experimentado por políticos tanto ao concorrerem à reeleição ao cargo que ocupam, quanto ao disputarem outro cargo eletivo. Documenta-se, então, que a incumbência de cargos legislativos aos níveis estadual e federal encontra-se associada a um expressivo efeito positivo sobre a probabilidade de vitória da disputa seguinte pelo mesmo cargo, ao passo que mandatários de governos locais não aparentam ser eleitoralmente beneficiados por tal status, podendo ainda ser prejudicados por tal condição no caso de exibirem pouca experiência política. Além disso, verifica-se que deputados estaduais também usufruem de uma vantagem eleitoral da incumbência ao disputarem o cargo de deputado federal, e rejeita-se que tal efeito, bem como os impactos sobre a probabilidade de ser reeleito a um mesmo cargo, seja devido à seleção em novas candidaturas. À exceção da transição do cargo de deputado estadual para o de deputado federal, no entanto, mandatários de qualquer cargo tendem a ser menos propensos do que seus homólogos derrotados a se candidatar e a vencer eleições para outros cargos. Na segunda parte, investigamos se transações clientelistas podem ser sustentadas através da observação, por parte de partidos políticos e candidatos, do status de filiação partidária dos eleitores. Argumenta-se que, sendo tal filiação um exemplo de demonstração pública de apoio a um partido, tentativas de compra de voto por partidos podem se tornar mais eficazes quando direcionadas a eleitores que sejam filiados, ou no intuito de que venham a sê-lo. Por meio do emprego de dados eleitorais e demográficos acerca de municípios brasileiros, observa-se que eleitores filiados a partidos das coligações municipais do Partido dos Trabalhadores são significativamente mais propensos (relativamente a eleitores em geral) a passar a receber benefícios do Programa Bolsa Família quando da eleição de tais partidos. Investigam-se também determinantes políticos da filiação partidária, e encontra-se que o simples fato de ser o mandatário de governos locais afeta os níveis de filiação ao partido correspondente apenas em situações específicas; por outro lado, a provisão de pagamentos do Bolsa Família apresenta um efeito positivo e robusto sobre a evolução dos índices de filiação. Por fim, a terceira parte investiga o potencial exibido por professores com elevada participação política de influenciar resultados eleitorais ao induzirem os votos de seus alunos. Explora-se tal questão através da utilização de dados sobre filiação partidária e sobre professores de ensino médio de escolas estaduais no estado de São Paulo, Brasil. Combinando-se informações sobre o status de filiação partidária de tais professores com dados sobre resultados eleitorais e características do eleitorado, investiga-se especificamente a relação entre a densidade de professores filiados e o desempenho eleitoral dos partidos em uma dada região. Problemas de endogeneidade, como os possivelmente decorrentes da alocação de professores a escolas, são evitados por meio da exploração de variação na intensidade do efeito proposto de acordo com características do eleitorado em um nível ao qual eleitores (e professores) não são capazes de se selecionar. Os resultados relacionados sugerem um efeito positivo e significante da presença de professores filiados sobre o desempenho eleitoral dos partidos, particularmente em eleições majoritárias. No entanto, a evidência apresentada indica que tal efeito é aparentemente restrito a professores filiados ao Partido dos Trabalhadores, e que tais professores são capazes de alterar as preferências políticas de alunos que compareceriam à votação independentemente de sua influência. 


\begin{abstract}
This thesis is divided into three parts. The first part deals with the issue that in a political environment wherein the development of a political career may encompass frequent transitions between offices, it is usually unclear how winning a given position may ultimately affect subsequent electoral performances and career formation. We exploit regression discontinuity designs in Brazilian elections to estimate the electoral advantage derived by incumbents of various positions both when running for reelection to the same held position, and when trying to win a different elective office. Then, we document that incumbency in legislative offices at state and federal levels is associated with a strong positive effect on the probability of winning the same position in the following election, whereas officeholders in diverse branches of local government do not appear to benefit electorally from their incumbency status and may even be harmed by it when they have relatively little political experience. Moreover, we find that state deputies also receive an incumbency advantage when running for the position of federal deputy, and that such a cross-office effect, along with all incumbency effects on winning the same position, is not due to selection into candidacy. Aside from the transition from state deputy to federal deputy, however, incumbents of any position tend to be less likely than their defeated counterparts to run for, and win, other positions. In the second part, we investigate whether incentive-compatible clientelistic transactions may be sustained through the observation of voters' party-affiliation status by politicians. We argue that since affiliation consists of an instance of public demonstration of support for a given party, vote-buying attempts by parties may be made more effective by targeting voters that are (or in order for them to become) affiliated to them. Using electoral and demographic data on Brazilian municipalities, we find that voters affiliated to parties in the municipal coalition of the Workers' Party are significantly more likely to start receiving benefits from the Bolsa Familia program upon the incumbency of a party in that coalition. We also investigate political determinants of party affiliation and find that while partisan incumbency at the local level appears to affect affiliation only in restricted situations, the provision of payments from the Bolsa Familia has a robust positive effect on affiliation. Lastly, the third part investigates the extent to which teachers with strong partisan stances are capable of influencing electoral outcomes through shaping their students' voting behavior. We address this question by exploiting unique datasets on party-affiliated voters and on public high school teachers in the state of São Paulo, Brazilthrough which we are able to identify teachers' political affiliations. Along with such information, we also make use of very rich datasets on election results and voter characteristics to explore the relationship between the density of affiliated teachers in a given region and electoral outcomes observed for that region. To overcome endogeneity issues such as that of selection in the assignment of teachers to schools and of voters to polling places, for instance, we explore the varying intensity of the hypothesized effect according to electorate characteristics at the polling station level, a very specific site within the polling district to which voters and teachers are suggested not to be able to select themselves. Our results are suggestive of a positive and significant effect of the presence of affiliated teachers on the electoral performance of the corresponding party, especially in elections based on plurality voting systems. However, our evidence also indicates that such an effect is more relevant for (and possibly restricted to) teachers affiliated to the Workers' Party, and that these teachers appear to be altering political preferences of students that would turn out to vote regardless of their influence.
\end{abstract}




\section{TABLE OF CONTENTS}

List of Tables $\quad 5$

\begin{tabular}{ll}
\hline List of Figures & 7
\end{tabular}

1 Political Career Building and the Electoral Effect

of Incumbency: Evidence from Brazil $\quad 9$

1.1 Introduction . . . . . . . . . . . . . . . . . . . . . . 9

1.2 Institutional Background $\ldots \ldots \ldots \ldots \ldots$. . . . . . . . . . . . . 14

1.3 Data . . . . . . . . . . . . . . . . . . . . . . . . . . . 17

1.4 Stylized Facts $\ldots \ldots \ldots \ldots$. . . . . . . . . . . . . . . . . 20

1.4 .1 The Propensity to Stay in Politics. . . . . . . . . . . . . . . . . . 20

1.4 .2 Incumbency Advantage and Office Turnover . . . . . . . . . . . . 23

1.4.3 Career Building: Common Trajectories . . . . . . . . . . . . . . . 25

1.4.4 Party Switching . . . . . . . . . . . . . . . . . . . . . 30

1.5 Empirical Strategy $\ldots \ldots \ldots$. . . . . . . . . . . . . . . . . . . . 31

1.6 Estimation Results $\ldots \ldots \ldots$. . . . . . . . . . . . . . . . . . . . . . . . . . 34

1.6.1 City Councilor . . . . . . . . . . . . . . . . . . 37

1.6 .2 Mayor . . . . . . . . . . . . . . . . . . . . . 42

1.6.3 State Deputy . . . . . . . . . . . . . . . . . . . . . 45

1.6.4 Federal Deputy . . . . . . . . . . . . . . . . . . . . . . . 47

1.7 Bounds on Effects on Winning Conditional on Candidacy . . . . . . . . . 49

1.8 Other Incumbency Effects Conditional on Candidacy . . . . . . . . . . . 55

1.8 .1 Effects on Campaign Spending . . . . . . . . . . . . . . 55

1.8.2 Effects on Party Switching . . . . . . . . . . . . . . . . . 58

1.9 Concluding Remarks . . . . . . . . . . . . . . . . . . 60

References for Chapter $1 . \ldots \ldots \ldots$. . . . . . . . . . . . . 61

\begin{tabular}{|ll}
\hline Appendices to Chapter 1 & 66
\end{tabular}

1.A Data Construction . . . . . . . . . . . . . . . . . . 66

1.A.1 Uniqueness by Election . . . . . . . . . . . . . . . . . . . 66

1.A.2 Matching Candidates across Elections . . . . . . . . . . . . . . . . 67

1.B Additional Figures . . . . . . . . . . . . . . . . . . . . . . . . . . . . . . . . . . . . . . .

1.C Additional Tables . . . . . . . . . . . . . . . . . . . . . . . . . . 75

2 Party Affiliation and Clientelism: Evidence from Brazil $\quad 85$

2.1 Introduction . . . . . . . . . . . . . . . . . . 85

2.2 Institutional Background . . . . . . . . . . . . . . . . . . . . . . . . 90

2.2 .1 Party Affiliation in Brazil . . . . . . . . . . . . . . . . . . . . . 90

2.2 .2 The Bolsa Familia CCT Program . . . . . . . . . . . . . . . . . . 91

$2.2 .3 \quad$ Evidence of Corruption from the Press and Audit Reports . . . . 93

2.3 Data . . . . . . . . . . . . . . . . . . . . . . . . 95

2.4 Empirical Strategies and Results . . . . . . . . . . . . . . . . . 96

2.4 .1 Targeting of Bolsa Familia Payments to Affiliated Voters . . . . . 96 
2.4 .2 Local Government Incumbency and Party Affiliation . . . . . . . 103

2.4 .3 The Impact of Bolsa Familia Coverage on Party Affiliation . . . . 108

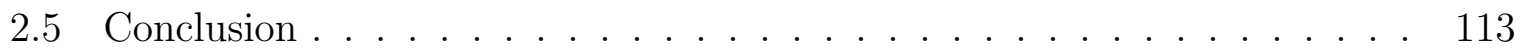

References for Chapter 2 . . . . . . . . . . . . . . . . . . . . . . . . . 114

\begin{tabular}{|lr}
\hline Appendices to Chapter 2 & 117
\end{tabular}

2.A Additional Figures . . . . . . . . . . . . . . . . . . . . . . . . . . . . 117

2.B Additional Tables . . . . . . . . . . . . . . . . . . . . . . . . . . . . . . . 121

3 Political Preaching in the Classroom: Evidence from Party Affiliation

$\begin{array}{ll}\text { of Teachers in Brazilian Public Schools } & \mathbf{1 3 5}\end{array}$

3.1 Introduction . . . . . . . . . . . . . . . . . . . . . . . 135

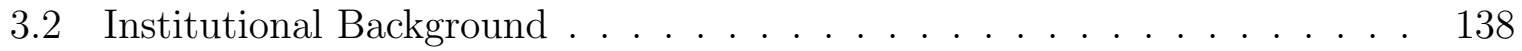

3.2 .1 Voting in Brazil . . . . . . . . . . . . . . . . . . . . . . . . . . . 138

3.2 .2 The Brazilian Public Educational System . . . . . . . . . . . . . . 139

3.2.3 Student and Teacher Placement in São Paulo's Public Schools . . 140

3.3 Data and Estimation Framework ． . . . . . . . . . . . . . . . . 140

3.4 Main Results . . . . . . . . . . . . . . . . . . . . . . . . . . . . . . 145

3.5 Further Exercises . . . . . . . . . . . . . . . . . . . . . . . . . . . . . . . 149

3.5 .1 Robustness Checks . . . . . . . . . . . . . . . . . . . . 149

3.5 .2 Effects on Turnout . . . . . . . . . . . . . . . . . . . . . 151

3.6 Conclusion . . . . . . . . . . . . . . . . . . . . . . . . . . . . . . 152

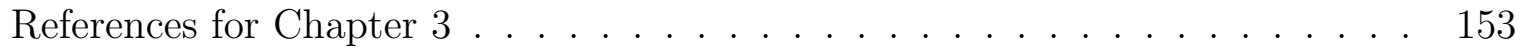

\begin{tabular}{lr}
\hline Appendices to Chapter 3 & 156
\end{tabular}

3.A Additional Tables . . . . . . . . . . . . . . . . . . . . . . . . . . . . 156

3.B Additional Figures $\ldots \ldots \ldots$. . . . . . . . . . . . . . . . . . 160 


\section{LIST OF TABLES}

Table 1.1: $\quad$ Number of Candidates by Position and Election Year . . . . . . . 19

Table 1.2: $\quad$ Probability of Running Again Before Term Ends (\%), by Outcome 21

Table 1.3: $\quad$ Probability of Running at Midterm (\%) . . . . . . . . . . 23

Table 1.4: $\quad$ Success Rate, by Position and Previous Candidacy Result . . . . 24

Table 1.5: $\quad$ Density of Elected Candidates Across Previous Candidacy Result 25

Table 1.6: Common Trajectories of Candidates Usually Holding Office . . . 28

Table 1.7: $\quad$ Frequent Continuous Paths . . . . . . . . . . . . . . . . 29

Table 1.8: $\quad$ Party Switching (\%), by Previous Candidacy Status . . . . . . . 30

Table 1.9: $\quad$ City Councilor - Incumbency Effects on Candidacy/Victory . . . 38

Table 1.10: City Councilor - Incumbency Effects by Recent Political Experience 39

Table 1.11: $\quad$ City Councilor - Incumbency Effects by Electorate Size 1 . . . . 40

Table 1.12: City Councilor - Incumbency Effects by Electorate Size 2 . . . . 41

Table 1.13: City Councilor - Incumbency Effects by Electoral Competition . 41

Table 1.14: $\quad$ First-Term Mayor - Incumbency Effects on Candidacy/Victory . 42

Table 1.15: $\quad$ First-Term Mayor - Incumbency Effects by Recent Political Expe-

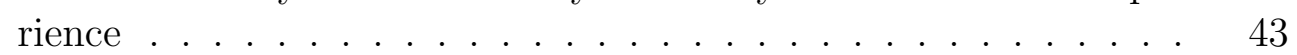

Table 1.16: Mayor - Incumbency Effects by Term . . . . . . . . . . . . . . . 44

Table 1.17: $\quad$ State Deputy - Incumbency Effects on Candidacy/Victory . . . . 45

Table 1.18: $\quad$ State Deputy - Incumbency Effects by Electoral Competition . . 46

Table 1.19: $\quad$ Federal Deputy - Incumbency Effects on Candidacy/Victory. . . . 48

Table 1.20: Incumbency Effects on Winning Conditional on Running - City

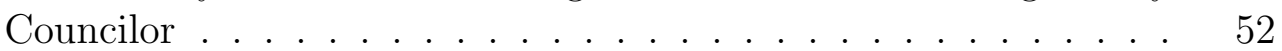

Table 1.21: Incumbency Effects on Winning Conditional on Running - FirstTerm Mayor . . . . . . . . . . . . . . . . . . . 53

Table 1.22: $\quad$ Incumbency Effects on Winning Conditional on Running - State and Federal Deputies . . . . . . . . . . . . . . . 54

Table 1.23: $\quad$ Effects on Campaign Spending - City Councilor . . . . . . . . . . . 55

Table 1.24: $\quad$ Effects on Campaign Spending - First-Term Mayor . . . . . . . . . 56

Table 1.25: $\quad$ Effects on Campaign Spending - State and Federal Deputies . . . 57

Table 1.26: Incumbency Effects on Party Switching . . . . . . . . . . . . . . 59

Table 1.A1: Incidence of Duplicated Registration Numbers, by Year. . . . . . 67

Table 1.A2: Fuzzy Merge Examples of Matched Observations . . . . . . . . . 68

Table 1.A3: Incidence of Individuals with Various Registration Numbers, by Position . . . . . . . . . . . . . . . . . . . 69

Table 1.C1: Migration across Offices and Retirement from Politics . . . . . . 75

Table 1.C2: Tests of Quasi-Random Assignment - City Councilor . . . . . . . 76

Table 1.C3: Tests of Quasi-Random Assignment - First-Term Mayor . . . . . 77

Table 1.C4: Tests of Quasi-Random Assignment - State Deputy . . . . . . . . . 78

Table 1.C5: Tests of Quasi-Random Assignment - Federal Deputy . . . . . . 79

Table 1.C6: Incumbency Effects on Candidacy and Winning - Federal Deputy, with Controls . . . . . . . . . . . . . . . . 80 
Table 1.C7: City Councilor - Incumbency Effects on Candidacy/Victory at Other Positions . . . . . . . . . . . . . . . . 81

Table 1.C8: First-Term Mayor - Incumbency Effects on Candidacy/Victory at Other Positions . . . . . . . . . . . . . . . . 82

Table 1.C9: State Deputy - Incumbency Effects on Candidacy/Victory at Other

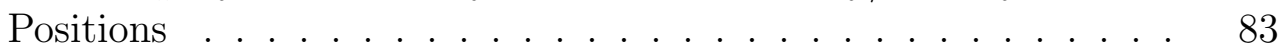

Table 1.C10: Federal Deputy - Incumbency Effects on Candidacy/Victory at Other Positions . . . . . . . . . . . . . . . . . 84

Table 2.1: $\quad$ PT Coalition Incumbency Effects on Bolsa Familia Targeting to Affiliated Voters . . . . . . . . . . . . . . . . . . 99

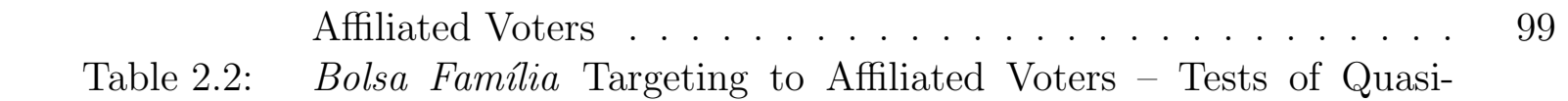

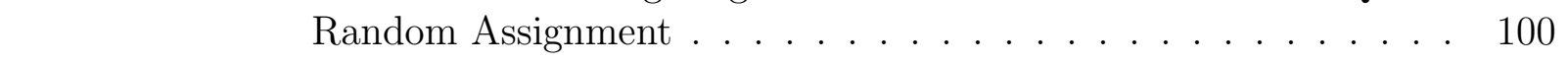

Table 2.3: $\quad B F$ Targeting to Affiliated Voters, by Population Size - Baseline

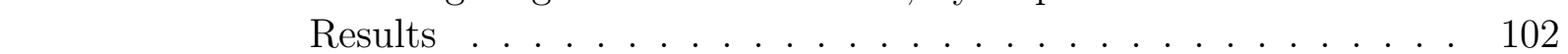

Table 2.4: $\quad B F$ Targeting to Affiliated Voters, by Population Size - Placebo

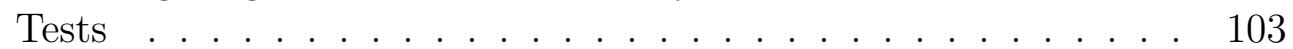

Table 2.5: $\quad$ Incumbency Effects on Voter Affiliation - Baseline Results . . . . 106

Table 2.6: $\quad$ Incumbency Effects on Voter Affiliation, by Literacy Rate (1/2) . 107

Table 2.7: $\quad$ Incumbency Effects on Voter Affiliation, by Literacy Rate (2/2) . 108

Table 2.8: $\quad$ Effect of Bolsa Familia on Party Affiliation - Baseline Results . . 111

Table 2.9: $\quad$ First Stage - Bolsa Família Beneficiaries (\%) Regressed on Instru-

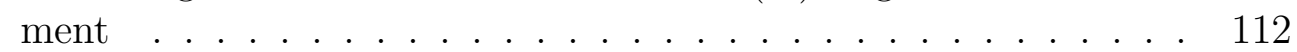

Table 2.10: $\quad$ Effect of Bolsa Familia on Party Affiliation - Robustness Checks 113

Table 2.B1: Summary Statistics for 2008-2012 Municipal Elections - PT Coalition Samples . . . . . . . . . . . . . . . . . . . . . 121

Table 2.B2: $\quad B F$ Targeting to Affiliated Voters - Validity Checks, by Population

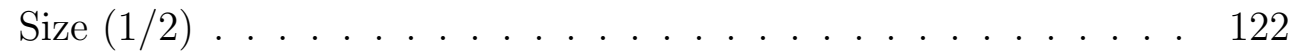

Table 2.B3: $\quad B F$ Targeting to Affiliated Voters - Validity Checks, by Population Size $(2 / 2) \ldots \ldots \ldots \ldots \ldots \ldots \ldots \ldots \ldots$

Table 2.B4: Summary Statistics for 1996-2008 Election Samples . . . . . . . 124

Table 2.B5: Incumbency Effects on Voter Affiliation - Validity Checks - PMDB 125

Table 2.B6: Incumbency Effects on Voter Affiliation - Validity Checks - PSDB 126

Table 2.B7: Incumbency Effects on Voter Affiliation - Validity Checks - PT] . 127

Table 2.B8: Incumbency Effects on Voter Affiliation - Validity Checks, by Literacy Rate - PMDB (1/2) . . . . . . . . . . . . . . . . . . 128

Table 2.B9: Incumbency Effects on Voter Affiliation - Validity Checks, by Literacy Rate - PMDB (2/2)] . . . . . . . . . . . . . . . . . . 129

Table 2.B10: Incumbency Effects on Voter Affiliation - Validity Checks, by Lit-

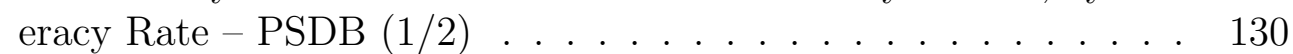

Table 2.B11: Incumbency Effects on Voter Affiliation - Validity Checks, by Literacy Rate - PSDB (2/2) . . . . . . . . . . . . . 131

Table 2.B12: Incumbency Effects on Voter Affiliation - Validity Checks, by Literacy Rate - PT (1/2) . . . . . . . . . . . . . . . . . . . 132

Table 2.B13: Incumbency Effects on Voter Affiliation - Validity Checks, by Literacy Rate - PT (2/2) . . . . . . . . . . . . . . . . . 133

Table 2.B14: Summary Statistics for All Municipalities, 2004-2012 . . . . . . . 134

Table 3.1: $\quad$ Share of Teachers Affiliated to Each Party . . . . . . . . . . . . . . 142 
Table 3.2: $\quad$ Effect of Teachers Affiliated to the PT on the Vote Share at the 2010 Presidential Election . . . . . . . . . . . . . . . . . . . . . 145

Table 3.3: $\quad$ Effect of Affiliated Teachers on Each Party's Vote Share in Different Elections . . . . . . . . . . . . . . . . . . . . 147

Table 3.4: $\quad$ Effect of Affiliated Teachers on Each Party's Vote Share in Different Elections - Placebo Group . . . . . . . . . . . . . . . . . 150

Table 3.5: $\quad$ Effect of Affiliated Teachers on Voter Turnout . . . . . . . . . . . . 152

Table 3.A1: Distribution of TSE Districts across Municipalities . . . . . . . . 156

Table 3.A2: Distribution of Municipalities across TSE Districts . . . . . . . . 156

Table 3.A3: Summary Statistics by Estimating Sample - 1/3 . . . . . . . . . 157

Table 3.A4: Summary Statistics by Estimating Sample $-2 / 3$. . . . . . . . . 158

Table 3.A5: Summary Statistics by Estimating Sample - 3/3 . . . . . . . . . 159 


\section{LIST OF FIGURES}

Figure 1.1: $\quad$ Inferred Trajectories - Absolute Frequencies . . . . . . . . . . . 26

Figure 1.2: $\quad$ Inferred Trajectories - Relative Frequencies . . . . . . . . . . . . 27

Figure 1.B1: McCrary Test - Distribution of Vote Share Margins, 1998-2010

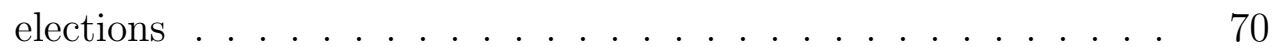

Figure 1.B2: Graphical Representation of Main Results - City Councilor . . . 71

Figure 1.B3: Graphical Representation of Main Results - First-Term Mayor . $\quad 72$

Figure 1.B4: Graphical Representation of Main Results - State Deputy . . . . 73

Figure 1.B5: Graphical Representation of Main Results - Federal Deputy . . 74

Figure 2.1: $\quad$ Share of Voters Affiliated to a Political Party in 2010 (\%), by

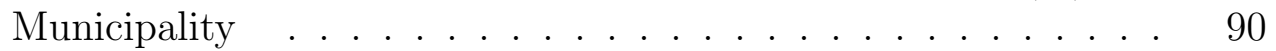

Figure 2.A1: McCrary Test - Distribution of Vote Share Margins, 2008-2012

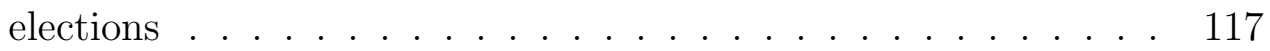

Figure 2.A2: Shares of Affiliates among New Beneficiaries . . . . . . . . . . . 118

Figure 2.A3: McCrary Test - Distribution of Vote Share Margins, 1996-2008 elections . . . . . . . . . . . . . . . . 119

Figure 2.A4: Electorate Becoming Affiliated (\%), by Party . . . . . . . . . . . 120

Figure 3.1: $\quad$ Administrative Hierarchy of Electoral Procedures in Brazil . . . 139

Figure 3.B1: Municipalities in the State of São Paulo. Highlighted: City of São Paulo ............................ 160

Figure 3.B2: Polling Districts in the City of São Paulo . . . . . . . . . . . . . 160

Figure 3.B3: A Public School Employed as a Polling Place . . . . . . . . . . . . 161

Figure 3.B4: A Public School Classroom Used as a Polling Station . . . . . . 161 


\section{Political Career Building and the Electoral Effect of Incumbency: Evidence from Brazil}

\section{$1.1 \quad$ Introduction}

In the last few decades, the widely noted electoral success of incumbents in established democracies has led scholars in the social sciences to broadly undertake the study of the assumed intrinsic advantage of holding a political office during reelection campaigns. A vast amount of empirical evidence on such advantage (received by both candidates and parties) has since been found, accompanied by numerous explanations for its existence, including incumbents' exclusive access to perquisites of office such as opportunities to perform constituency services, franking privileges, and higher visibility due to their inherent newsworthiness and disproportionate access to the media (Erikson (1971), Fiorina (1977), Krehbiel and Wright (1983), Ansolabehere et al. (2000) ). ${ }^{1}$ Also, it has been suggested that incumbency status serves as a cue in voting decisions when partisan ties are relatively weak and a candidate's party affiliation carries little weight (Erikson (1972), Nelson (1978) ). ${ }^{2,3}$

Regardless of the underlying mechanisms, the mere possibility of such an electoral advantage and its consequences for the duration of political careers has frequently kindled a debate over certain features of political and electoral systems all over the world, especially concerning term limits. On the one side, sympathizers with the Aristotelian position that a democratic citizenship is only fully achieved by the reciprocity of "ruling and being ruled by turn" argue that the power of incumbency and the common desire of politicians to pursue lifelong political careers significantly inhibits office turnover. They emphasize the fact that the advantage enjoyed by incumbents helps entrench political power and leads to unfair electoral contests that may favor low-quality over high-quality candidates; moreover, it is frequently suggested that career politicians lose touch with

\footnotetext{
${ }^{1}$ In the context of the Brazilian legislature, Boas and Hidalgo (2011) discuss a extreme case in which higher levels of media access are achieved by officeholders effectively gaining control of the media as a result of incumbency. In addition, they find that such direct influence over communication media increases candidates' probabilities of victory.

${ }^{2}$ These mechanisms, in turn, also strengthen arguments for the rather indirect effect referring to the ability of incumbents to deter potential challengers (even those of higher quality), who would be less inclined to contest elective seats upon knowing that incumbents are able to use office resources to improve their electoral prospects (Levitt and Wolfram (1997), Cox and Katz (1996)).

${ }^{3}$ For empirical evidence on the electoral advantage of incumbency, see also Lee (2008) and Ferreira and Gyourko (2009) for the United States, Ade et al. (2014) and Freier (2011) for Germany, and Redmond and Regan (2015) for Ireland.
} 
their constituents and with the public good. ${ }^{4}$ On the other side, defenders of the institution of reelection hold the notion that continuation in office - and the practice of governance by career politicians - is a critical condition for the promotion of the institutional strength of certain branches of government (as discussed by Polsby (1968) and Jones et al. (2002), for instance), and suggest that incumbents tend to perform better when facing the possibility of running for reelection. ${ }^{5}$

It is noticeable, however, that academic debates and policy discussions alike traditionally evaluate the electoral role of incumbency regarding only reelection to the same position. While this approach may seem adequate for the political scenarios analyzed by the earlier studies on the topic (mostly based on the U.S. Congress, for which reelection rates are historically very high), it is arguably less likely to be so for others, in which turnover rates are more significant. ${ }^{6}$ Specifically, for political environments wherein the development and continuity of a political career may involve (or possibly even require) relatively frequent transitions between different elective positions, the consideration of incumbency effects restricted to persistence in the same office may be a misguided strategy when investigating the accumulation of political power by professional politicians and the effective allocation of office resources to reelection campaigns. This would be the case, for instance, whenever incumbents of a given position are not reelected for it as a result of having moved to more attractive offices instead.

In this chapter, therefore, we investigate whether incumbents receive an electoral advantage from holding office not only when seeking reelection to the same position, but also when running for other offices. In doing so, our work particularly allows the assessment of more comprehensive impacts of incumbency status on candidates' electoral performances and future career decisions. We apply a regression discontinuity (RD) design to estimate the electoral effects of incumbency of four different positions contested in Brazilian elections: city councilor, mayor, state deputy, and federal deputy. We make use of a unique dataset with electoral information on candidates who entered races from 1998 to 2014, including all candidacies filed by each candidate in that period. For each given position, candidates who narrowly won are compared to those who narrowly lost in terms of their

\footnotetext{
${ }^{4}$ Accordingly, Grossman and Helpman (1996) argue that the electoral advantage of incumbency may induce officeholders to cater more to the concerns of special interest groups to the detriment of the welfare of the average voter, and that term limits are likely to diminish such influence.

${ }^{5}$ For instance, Ferraz and Finan (2011) find evidence that electoral accountability induced by the possibility of reelection constrains corruption practices of incumbent politicians, while De Janvry et al. (2012) study the implementation of a conditional cash transfer program targeted at the reduction of school dropout rates in Brazil, and find that the program's impact was larger in municipalities ruled by mayors who faced the possibility of reelection.

${ }^{6}$ Among others, Carey (2002), Jones et al. (2002), and Morgenstern (2002) argue that legislators in new democracies in Latin America are less likely to pursue long-term legislative careers than their U.S. Congress counterparts, for example.
} 
probabilities of winning the subsequent election for the same position as well as according to their chances of winning subsequent elections for other positions. In addition, we provide estimates of the corresponding incumbency effects on the probabilities of running in such subsequent elections, which enables us to evaluate the extent to which observed effects on winning may simply be due to a "scare-off" factor.

To our knowledge, our work is the first to specifically investigate impacts from the incumbency of a certain position on the probability of running for, and winning, another position. Nonetheless, our subset of results regarding incumbency effects on reelection to the same position may be seen as a parallel contribution to the literature in itself. In sharp contrast to the large body of research concerning established democracies, evidence on that traditional effect for developing countries has pointed to a negative or insignificant impact of incumbency in terms of electoral outcomes; however, that evidence is still scarce and the few existing studies may suffer from serious methodological issues that hinder causal interpretations of their results. For example, Uppal (2009) applies an $\mathrm{RD}$ design to estimate incumbency effects in Indian state legislative elections and finds a strong negative effect on the probability of being reelected to the same position, but only after restricting the analysis to candidates who run again. However, even in an RD setting such sample selection could lead to biased results if the decision to run again were endogenous to incumbency status (Lee (2008) $).{ }^{7}$ A similar issue is present in the work by Brambor and Ceneviva (2011), who find that Brazilian mayors face a significant incumbency disadvantage in seeking reelection. In turn, Klašnja and Titiunik (2013) apply an RD design to explore the incumbency advantage received by a small collection of parties in Brazilian mayoral elections. They find evidence of a strong negative effect on the probability of a party winning the following election (to that same position) and suggest that this is driven by the combination of a weak party system along with the imposition of constraints on electoral horizons (term limits) for individual candidates. ${ }^{8}$ Thus, the interpretation of such a partisan incumbency effect is ultimately built in terms of the electoral behavior of individual candidates rather than parties. Moreover, we note that the finding that parties receive an electoral disadvantage from incumbency in no way elucidates the question of whether incumbent candidates employ their offices' resources in their reelection campaigns, for instance. For these reasons, we opt to base our work on the analysis of incumbency effects faced by candidates.

Regarding the effects on reelection to the same position, we find that incumbency as a

\footnotetext{
${ }^{7}$ For instance, we could reasonably assume that candidates with better future electoral odds are more likely to run again. Alternatively, for a given election, it might be the case that narrow winners are more likely than narrow losers to retire from politics shortly.

${ }^{8}$ See also Linden (2004) and Aidt et al. (2011) for India, Miguel and Zahidi (2004) for Ghana, and Macdonald (2014) for Zambia; all these studies use close election RD designs.
} 
city councilor is associated with a decrease in the probability of winning the following election of around 5 percentage points (p.p.), despite also corresponding to an increase in the probability of running in that election by around 10 p.p. Similarly, our results suggest that incumbency as a mayor (with the possibility of reelection) decreases the probability of winning the next mayoral election and slightly increases the probability of running at that election; these results, however, are usually statistically insignificant. On the other hand, our main estimates indicate that incumbency as a state deputy increases both the probability of running in the following state assembly election (by 11.5 p.p.) and the probability of winning that election (by around 13 p.p.). Moreover, candidates for the position of federal deputy who barely win are around 14 p.p. more likely to run for that position again and almost 30 p.p. more likely to win relative to narrow losers. By considering the effects of the incumbency of positions that cover distinct levels (municipalities and states) and different branches (executive and legislative) of government, we are better able to evaluate the adequacy of some hypotheses proposed in previous research for mechanisms driving the corresponding results. For instance, the fact that negative effects on winning are verified for some positions but not for others indicates that they are not likely to be a result of political or economic instability, a suggestion frequently made in studies that find an incumbency disadvantage (Aidt et al. (2011), Uppal (2009)). Furthermore, given that negative effects are found for legislative positions (city councilor), which are not restricted by term limits, we suggest that the negative impacts found by Klašnja and Titiunik (2013) for incumbent mayors may also be driven by reasons other than solely the impossibility of reelection. In fact, further exploration reveals that negative effects of incumbency are only faced by inexperienced city councilors and mayors, who arguably possess less ability to take advantage of holding office.

As our main contribution, however, we find evidence that incumbency of some positions may offer an electoral advantage even when an incumbent is running for a distinct position. For example, our results suggest that incumbency as a city councilor increases the probability of winning any other position within four years by around 0.5 p.p. Despite the low magnitude, this effect is actually sizable given that the position of city councilor is arguably inferior to most elective positions and that less than $1 \%$ of candidates who lose elections for city councils end up winning another position in the following elections. Moreover, we observe that candidates for the position of state deputy who narrowly win are 1.47 p.p. (more than 200\%) more likely than those who narrowly lose to be successful in the following election for the position of federal deputy. On the other hand, we find that the effects of incumbency of a given position on the probabilities of running for, and winning, another given position tend to be negative when these two positions do not seem to show a clear-cut hierarchical relationship with respect to political career building; in 
other words, in those cases the act of running for a position different than that pursued in the last contested election occurs more frequently as a result of having lost rather than having won the preceding race.

In addition, we assess whether some of the incumbency effects on winning the same position, and on winning other positions, are simply driven by incumbents being more prone to run in subsequent elections. We adapt a methodology devised by Lee (2009) and Anagol and Fujiwara (2015) to obtain bounds on the effects on winning conditional on running. We then find that incumbency as a city councilor or as a mayor decreases the probability of winning the same position conditional on running for it, since the corresponding upper bounds are negative. As in the case of unconditional effects, however, we see that these negative conditional effects appear to be restricted to inexperienced incumbents, while experienced ones do not seem to receive any relevant impacts from incumbency. Also, our results indicate that incumbency either as a state deputy or as a federal deputy is associated with an increase in the probability of winning the same position conditional on running, as the corresponding lower bounds are positive. Thus, incumbency of these positions increases not only candidates' propensities to run for them again, but also their chances of winning conditional on running. Regarding conditional effects on winning another position, we also find that incumbency as a state deputy increases the probability of winning the position of federal deputy in the following election, conditional on running for it. Lastly, the same methodology is employed in some extensions, wherein we investigate conditional effects of incumbency on other aspects of electoral competition and political careers, namely campaign spending and party switching.

In investigating the role of incumbency status in transitions between offices, our work also relates to the literature on the study of political ambition and political career choices, which has mostly focused on congressional career building. In seminal work, Schlesinger (1966) classifies politicians in terms of their ambitions and evaluates how U.S. legislators' behavior is affected by their desire to withdraw from public office, to build a career out of a particular office, or to attain a more important office. ${ }^{9}$ Also, Rohde (1979) and Brace (1984) build ambition theory into decision-theoretical models for studying progressive ambition in the U.S. House of Representatives. ${ }^{10}$ On the other hand, most research on legislative turnover has assumed that incumbents' ambitions consist mostly of aspiring for reelection to the same office and establishing seniority systems (Mayhew (1974), Hall and Van Houweling (1995), Herrick and Nixon (1996), Epstein et al. (1997)). Regarding the Brazilian political context, Samuels $(1998,2000)$ argues that Brazilian legislators in

\footnotetext{
${ }^{9}$ Herrick and Moore (1993) argue for the need that the typology proposed by Schlesinger $(1966)$ be extended to include intrainstitutional ambition.

${ }^{10}$ See also Kiewiet and Zeng (1993) for a simultaneous consideration of the issues of political ambition and retirement in the U.S. House of Representatives.
} 
the lower house of Congress display high turnover rates and relatively unstable career paths as a result of a generalized ambition to secure an executive branch office. Alternatively, empirical evidence on the notion that such progressive ambition is actually quite unusual among these legislators is provided by Leoni et al. (2004) and Pereira and Rennó (2007). Aside from considering positions other than that of federal deputy, our study of incumbency effects contributes to that literature in providing a characterization of future political career decisions, not only for incumbents, but also for defeated candidates.

The remainder of the chapter is organized as follows. Section 1.2 discusses the institutional background of the Brazilian electoral system, and Section 1.3 describes the data. Stylized facts regarding incumbency advantage and political career paths in Brazil are presented in Section 1.4. Section 1.5 discusses the empirical methodology. Our main results are presented in Sections 1.6 and 1.7, and Section 1.8 analyzes some extensions. Section 1.9 concludes the chapter.

\section{$1.2 \quad$ Institutional Background}

Brazil is a presidential federation of more than 5,500 municipalities - Brazil's smallest administrative units - distributed across 26 states and the Federal District. ${ }^{11,12}$ Each municipality has its own elected mayor (Prefeito) and a relatively weak legislature (Câmara de Vereadores), which adds up to almost 60,000 city councilors nationwide. ${ }^{13}$ Similarly, each state has a unicameral state assembly (Assembleia Legislativa), adding up to a total of 1,059 state deputies nationwide, and a governor (Governador). Elections for both the federal senate and for the lower chamber of congress are also performed at the state level. Each state is entitled to three seats in the senate, while the number of seats as federal deputies for each state (within a total of 513) depends upon the number of seats of the corresponding state assembly, which is itself determined according to the state population (as the number of city councilors in a local legislature depends on the population in the municipality).

Chiefs of subnational executive offices (mayors and governors) tend to receive more media attention and political credit relative to their legislative counterparts, partly because they enjoy considerable discretionary power over important political nominations and pork-

\footnotetext{
${ }^{11}$ The number of Brazilian municipalities has slightly increased over the last decades: in 2000, there were 5,561 municipalities in Brazil, in 2014, 5,570.

${ }^{12}$ Henceforth, the Federal District will be treated as one of 27 states, given their similarity in relation to electoral rules and form of government. Likewise, members of the legislative assembly of the Federal District are treated as ordinary state deputies.

${ }^{13}$ On the relative weakness of Brazilian local legislatures, see Couto and Abrucio $(1995)$.
} 
barrel funds - especially in large constituencies (Samuels (1998), Montero (2005), Ames (2009)). For that reason, it has been argued that these positions present themselves as an attractive destination for some legislators (Samuels $(1998,2000)) .{ }^{14}$ The set of elective positions in Brazil also includes (and is fully completed by) vice-mayors (one per municipality), vice-governors (one per state), alternate senators (two per elected senator), and the presidency and vice-presidency. ${ }^{15}$

Brazilian federal law dictates that elections for each position occur every four years, and that all state and federal elections are held on the same date. ${ }^{16}$ Local elections are also held simultaneously across municipalities, but are staggered by two years relative to general elections. Thus, this structure forces elected officials concerned with developing a political career to face new candidacy decisions every two years. In particular, such timing may arguably be seen as a key factor for explaining a possibly high frequency of transitions between offices in Brazil, as it allows candidates to engage in contests more frequently (which they may desire in order to increase their interactions with voters), and as office-seeking candidates may then be more tempted to run for and take a less desirable office if they can run again for a more attractive office two years later (rather than four). However, while officials elected to legislative positions are not restricted by term limits and do not need to relinquish their mandates to run again (for any position), those elected to executive offices are only entitled to run for the same position (in the same constituency) for one consecutive term, and have to step down if they want to run for another position. ${ }^{17}$ Therefore, an incumbent of an executive office who wishes to maintain a relatively uninterrupted political career (in elective positions) will eventually have to switch to another level of government or to a legislative position. On the other hand, unlimited non-consecutive reelection is always allowed. It is also worthwhile noting the fact that all constituencies (municipality or state) related to a given election (at the local or general level) are subject to the same election rules, which gives a fair degree of homogeneity to the Brazilian electoral and political institutional backgrounds, allowing for an adequate scenario for the empirical investigation of political careers.

The Federal Constitution and electoral law also establish some requirements that citizens must meet in order to be eligible to run for an elective position and to take office. In particular, all candidates must have been affiliated to a political party for at least one

\footnotetext{
${ }^{14}$ In particular, municipalities have benefited from a generalized process of decentralization of policy responsibilities. See, for example, Gemignani and Madeira (2015).

${ }^{15}$ Candidates for mayor and vice-mayor run on the same ticket, and the same happens for candidates for governor and vice-governor, and for senator and alternate senator.

${ }^{16}$ Elections are always held in the month of October of even years, and elected candidates take office at the beginning of the following year.

${ }^{17}$ For the period under analysis, a mayor in his or her second term was able to run for a third consecutive term as mayor in a different municipality, as long as he/she resigned at least six months before the new election.
} 
year at the time of election, while parties may require even longer periods of affiliation as a condition of candidacy. ${ }^{18}$ Moreover, eligibility for an elective position is also subject to minimum age requirements that vary according to the specified positions. Candidates elected for positions on city councils are required to be at least 18 years old by the time of inauguration, while elected mayors, vice-mayors, state deputies, and federal deputies must be at least 21. Officials elected for governor and vice-governor must be 30 or older, and elected senators, alternate senators, presidents, and vice-presidents must be at least 35.

While elective positions in executive offices are filled under a plurality rule, ${ }^{19}$ all legislators (except for senators) are elected under an open-list proportional representation system. ${ }^{20}$ Moreover, parties may form coalitions before elections irrespective of the corresponding electoral system. Under the proportional representation system, however, forming a coalition provides parties with an additional advantage: while single parties may put forward a maximum number of candidates equal to 1.5 times the number of seats in the corresponding legislative body, coalitions may put forward twice as many candidates as there are seats. ${ }^{21}$ Also, each voter may cast a vote for a party or for a particular candidate, and traditionally tends to choose the latter option. ${ }^{22}$ Regarding the definition of which candidates are elected for each position under these rules, each coalition is treated as a party and seats are allocated to parties/coalitions in proportion to their percentage of the vote using a procedure equivalent to the D'Hondt method. Then, the seats allocated to each party/coalition are awarded to the best-performing candidates on their lists (i.e. according to the rank-order of the candidates' personal votes rather than from an ordering imposed by the parties).

These features of the Brazilian electoral system coupled with low levels of party identi-

\footnotetext{
${ }^{18}$ Some exceptions are former magistrates and members of the armed forces, who need only to have been affiliated for six months. Active members of government-related groups such as those are prohibited by the Constitution from affiliating to a political party.

${ }^{19}$ A simple plurality rule is used for mayoral elections in municipalities with fewer than 200,000 voters, while a two-ballot system is used in municipalities with larger numbers of voters and in all elections for governor and president.

${ }^{20}$ Senators are elected on a majority basis. Also, as opposed to the other elective positions, senators serve eight-year terms. Elections for senator are then staggered so that one-third of the senate is up for election in one election and two-thirds are renewed at the next election. In each case, a voter casts a number of votes equal to the number of seats up for election, and the (one or two) candidates with the greatest numbers of votes are elected in a single round.

${ }^{21}$ A given party may form part of different coalitions in elections for different positions, but the diversity of coalitions across positions related to the same level of government is somewhat restricted. For instance, two parties who are part of different coalitions for a city council election in a given municipality may not be part of the same coalition disputing the mayoral election in that municipality.

${ }^{22}$ Voting is facultative in Brazil for citizens aged 16-17 or over 70 (on election day), and for illiterate people. For all literate citizens aged 18-70, voting is mandatory and unjustified voting abstention results in fines or other legal penalties.
} 
fication and political interest among the electorate, ${ }^{23}$ have long underpinned arguments explaining the general weakness of parties in Brazil, as individual candidates and officials are given incentives to pursue individualistic campaign and career strategies rather than to highlight characteristics of their party, and parties display little ability to discipline their elected members (Ames (2002), Power and Roberts (1995), Mainwaring (1991, 1993), Kinzo and Dunkerley (2003)). In particular, this focus on individual self-promotion may take place even to the detriment of party loyalty. ${ }^{24}$ As argued by Desposato (2006) and Melo (2000), party switching is a persistent and endemic phenomenon in Brazil's Chamber of Deputies, and its timing is suggestive of its being shaped by career concerns. This largely shared notion of a weakly institutionalized Brazilian party system also motivates us to investigate the particular issue of how political career decisions are reflected in the party loyalty (or lack thereof) displayed by candidates and incumbents (as measured by party switching).

\subsection{Data}

The main outcomes investigated in this chapter refer to whether a candidate for a given elective position runs in, and wins, a subsequent election for the same position as well as for other (elective) positions. In light of the discussion presented above on the candidatecentered (non-partisan) nature of Brazilian elections and on the pervasiveness of party switching, we focus on candidates - rather than parties - as the unit of analysis. In particular, as evidenced by Klašnja and Titiunik (2013), important (and somewhat diverging) results on the effects of party incumbency frequently found in the literature may actually be driven by a particular underlying behavior of the corresponding candidates, as the main restrictions on running for election (such as term limits) apply to candidates, not the parties. When proportional representation elections are concerned, focusing on candidates also leads to a clearer and more natural definition of incumbency than when parties are considered. Moreover, the relatively high number of party mergers and splits, as well as name changes, that have taken place in Brazil in recent decades further complicates analyses that attempt to measure party outcomes across time, possibly making them less comparable.

\footnotetext{
${ }^{23}$ Interestingly, the low level of interest in politics and parties presented by citizens occurs in spite of the astonishingly high number of parties in Brazil (32 in early 2015).

${ }^{24}$ The legal establishment of penalties such as the loss of mandate for party switching (or disaffiliation) by an incumbent was removed by a constitutional amendment in 1985, in light of the ongoing process of redemocratization in Brazil. In 2007, the Brazilian electoral authority (Tribunal Superior Eleitoral) promulgated a law reinstituting mandate loss as a sanction for unjustified party disloyalty by incumbents elected under proportional representation rules. However, a disloyal incumbent may lose his or her mandate only after a ruling on a lawsuit to be filed by the corresponding party.
} 
To assess the effects of incumbency on a candidate's political career, we constructed a unique dataset based on publicly available information from the federal electoral authorityTribunal Superior Eleitoral (TSE) — covering all elections in the 1998-2014 period (four rounds of local elections: 2000, 2004, 2008 and 2012, and five rounds of general elections: 1998, 2002, 2006 and 2010). ${ }^{25}$ For all years, the TSE provides the candidate's name, the position contested and corresponding electoral district, and the candidate's electoral outcome (number of votes and winning status) and party affiliation. Data on candidates' campaign expenditures are also available since 2002. Most importantly, for the years in our dataset the electoral authority also provides each candidate's voter registration number (Título Eleitoral), a government-issued document unique to each voter, which was used to track candidates across elections. ${ }^{26}$ The most relevant issues faced while performing this matching (such as the occurrence of non-unique registration numbers) - and how they were dealt with - are discussed in detail in the appendices. We then define a candidate as running for a specific subsequent election if he or she is matched to a candidate in that election's candidate list; in that definition, we do not restrict subsequent candidacies to refer to the same constituency as that of the baseline candidacy. ${ }^{27}$ Table 1.1 summarizes the number of candidates running for each position in the period covered by the data. Overall, our dataset comprises information on 1,751,830 candidacies related to $1,184,420$ distinct individuals.

In addition, we make use of data at the constituency-position level (also from the TSE) on electorate sizes, party coalitions, and the number of votes received by each party to construct precise measures of vote margins for candidates running under proportional representation rules. Moreover, we rely on other political and demographic data from the Brazilian Institute of Geography and Statistics-Instituto Brasileiro de Geografia e Estatistica (IBGE) - and from the TSE to assess the validity of our RD analysis as well as to search for heterogeneity in the incumbency effects under analysis. These data include information on constituencies' Gini coefficients, Human Development Index, longitude and latitude, ${ }^{28}$ number of seats per elective position, and on candidates' dates of birth, education levels, occupations, and marital status.

\footnotetext{
${ }^{25}$ These data were collected from the electoral authority's website: http://www.tse.jus.br. Supplemental elections held outside regular official dates are rare and were not included in the sample.

${ }^{26}$ Information on elections before 1998 is also available from the federal authority's website, but for those elections voter registration numbers are missing, as are most instances of candidates' dates of birth. Also, performing a matching based solely on the candidates' names would be computationally too cumbersome, and conditioning subsequent candidacies to be related to the same district as the "baseline" candidacy could be too restrictive for some positions. For these reasons, these data were not included in the sample.

${ }^{27}$ Analogously, the matching outcome is used to determine whether candidates are incumbents and which incumbents of executive offices are in their second consecutive terms.

${ }^{28}$ The longitude and latitude of each state were considered to be that of the corresponding capital city.
} 


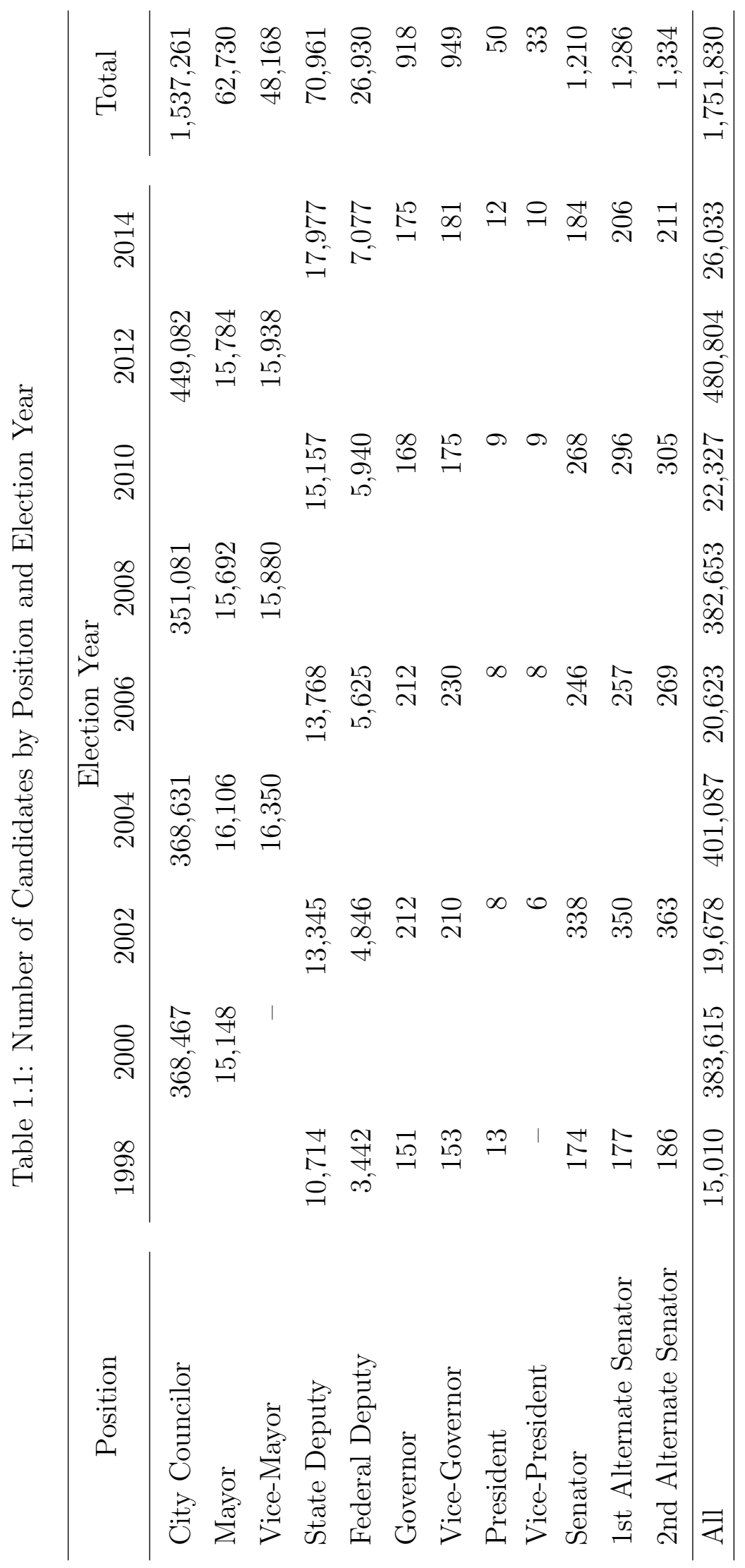




\subsection{Stylized Facts}

Before providing an analysis of incumbency effects on political career decisions with a causal interpretation, we dedicate this section to presenting some stylized facts verified from the data. We begin by investigating candidates' propensities to run again as a measure of their willingness to stay in politics. Then, we provide some statistics to give an indication of the electoral advantage stemming from holding office, and to illustrate the degree of office renewal (based on turnover rates). We also describe the most frequent trajectories followed by candidates while developing their political careers, and briefly discuss the extent of party switching in new candidacy decisions.

\subsubsection{The Propensity to Stay in Politics}

First, for each elective position $p_{0}$, we investigate the probability that a candidate running at $t$ will decide to run again (for any position) in the time frame defined by $p_{0}$ 's term duration (eight years for the position of senator and four years for all other elective positions). We contrast the corresponding probabilities shown by subgroups of candidates that alternately won or lost an election for each given position in order to assess whether there is any indication of a connection between incumbency status and the propensity to run again. Moreover, that comparison is made by making use of two distinct samples of candidacies: besides using a sample that pools candidacies in the data ("Pooling Candidacies"), we also employ a restricted subsample consisting of candidacies that amount to a first try at the given position by the corresponding individual ("1st-Timers"). For instance, if a certain candidate ran for the position of city councilor in 2000 and 2004, his or her 2004 candidacy is considered in the former but not in the latter sample; also, his or her 2000 candidacy is considered in the pooling sample, but only included in the "1st-Timers" sample if we are able to determine that the candidate did not run for city council prior to 2000 (regardless of whether he or she did run for another position before that year). We note, however, that the determination of a candidacy as first-time is based solely on considering the candidate's age along with the minimum age requirements for candidacy to each position, which means we are not able to uncover all cases of first-time candidacies (to each position). ${ }^{29}$

Table 1.2 provides the corresponding statistics. We observe that, for each sample of candidacies and for each given position, winning candidates tend to show a higher probability

\footnotetext{
${ }^{29}$ For instance, we are unable to assess whether a 30-year-old candidate running for mayor in 2000 is doing so for the first time, as he or she could have run for this position in an election absent from the data (e.g. in 1996).
} 
of running again than losers. The exceptions consist of candidacies for a second (consecutive) term in a given executive position (second-term mayor and second-term governor); for these positions, however, winning for a second time would prevent the corresponding candidate from running for the same position for a third consecutive term, so these results should be expected. We see, for instance, that more than $80 \%$ of the successful candidacies (i.e. candidacies whereby the corresponding candidates were elected) for city council were followed by a new candidacy within four years, whereas for failed attempts at that position the same happened in only $30 \%$ of cases. Also, all of the candidates who ran for the position of federal deputy for the first time and won ran again within four years, while fewer than half of those who ran for that position for the first time and lost did so.

Table 1.2: Probability of Running Again Before Term Ends (\%), by Outcome

\begin{tabular}{|c|c|c|c|c|c|c|}
\hline \multirow{3}{*}{$\begin{array}{l}\text { Position of } \\
\text { Candidacy }\end{array}$} & \multicolumn{4}{|c|}{ Running again before term ends $(\%)$} & \multicolumn{2}{|c|}{$\begin{array}{c}\text { Winner/Loser } \\
\text { Prob. Ratio }\end{array}$} \\
\hline & \multicolumn{2}{|c|}{ Pooling Candidacies } & \multicolumn{2}{|c|}{ 1st-Timers } & \multirow{2}{*}{$\begin{array}{c}\text { Pooling } \\
\text { Candidacies }\end{array}$} & \multirow{2}{*}{ 1st-Timers } \\
\hline & Winner & Loser & Winner & Loser & & \\
\hline City Councilor & 82.60 & 30.26 & 74.96 & 21.36 & 2.73 & 3.51 \\
\hline 1st-Term Mayor & 75.03 & 52.59 & 76.06 & 52.01 & 1.43 & 1.46 \\
\hline 2nd-Term Mayor & 3.07 & 48.37 & & & 0.06 & \\
\hline State Deputy & 92.33 & 47.86 & 93.14 & 39.14 & 1.93 & 2.38 \\
\hline Federal Deputy & 92.20 & 51.45 & 100.00 & 44.85 & 1.79 & 2.23 \\
\hline 1st-Term Governor & 80.36 & 67.66 & 100.00 & 67.06 & 1.19 & 1.49 \\
\hline 2nd-Term Governor & $64.00 \dagger$ & $90.00 \dagger$ & & & 0.71 & \\
\hline Senator & 87.16 & 67.18 & 100.00 & 70.11 & 1.30 & 1.43 \\
\hline All & 78.93 & 32.21 & 74.74 & 24.18 & 2.45 & 3.09 \\
\hline
\end{tabular}

The "Pooling Candidacies" sample pools observations on candidacies related to elections for the Senate held prior to 2008 and to elections for other positions held prior to 2012. The "1st-Timers" sample encompasses only those candidacies that amount to a first try at the specified position by the corresponding individual. $\dagger$ indicates that the corresponding statistic is based on fewer than 30 observations.

Moreover, the last two columns in that table show that the higher propensity to run again displayed by winning candidates is relatively larger when only first-time candidacies for each position are taken into account. For instance, successful candidacies for state deputy are $93 \%$ more likely than failed candidacies to be followed by another candidacy (from the corresponding individual) within four years, whereas candidates who run for state deputy for the first time and win are $138 \%$ more likely to run again in that time frame than candidates who run for that position for the first time and lose. For all positions, such a difference may be due to a higher probability of giving up on a political career by losing candidates who are running for the first time relative to losing candidates in general; that 
is, candidates may be more discouraged from staying in politics upon failing in their first attempt at a given position than upon failing in other moments of their (already initiated) careers. Also, the higher propensity to run again upon winning a given position for the first time relative to winning it in any attempt is consistent with higher retirement rates (concerning political activities) among older candidates.

Next, we investigate the probability that a candidate elected for each position will retire from politics (at least in the near future), run again for the same position at the end of his or her mandate, or run for another position before his or her mandate ends. We again provide statistics for two samples of candidacies (mandates): one that pools all successful candidacies in the data, and a sample of those successful candidacies that led to a first victory at the corresponding position; Table 1.C1 in the appendices provides the associated results. Our data shows that around $12 \%$ of victories are followed by a candidacy to another position, but also that this proportion varies greatly across positions. Officials elected to executive offices exhibit lower chances of running for another position before their terms end, which reflects the cost of stepping down that they must bear if they want to do so. For instance, less than $1 \%$ of successful candidacies for a first (non-consecutive) term as mayor are followed by a candidacy to another position, whereas almost $60 \%$ of successful candidacies for senator lead to the decision to migrate to another office. It also appears that the choice by incumbents to run for another office is strengthened upon gaining further experience in the same position, since candidacies related to a victory for the first time ("1st-Time Mandates") tend to be less frequently followed by candidacies to a distinct position than candidacies related to victories in general ("Pooling Mandates"). ${ }^{30}$

In addition, to gain further understanding of the configuration of migration across offices in Brazil, we explore the extent to which elected candidates run for election again at midterm. ${ }^{31}$ As shown in Table 1.3 , candidates elected to executive positions very rarely choose to run for another position at midterm (which reflects their previously discussed low propensities to run for another position before their mandates end). The same situation applies to candidates elected as city councilors, whereas those elected for other legislative positions exhibit fairly high probabilities of running at midterm. In addition, candidates elected to a certain position for the first time ("1st-Time Mandates") are usually only slightly less likely to run at midterm than candidates who win that position irrespective of having won it before. In relation to the position of city councilor, however, successful candidacies overall are more than twice as likely to be followed by a candidacy

\footnotetext{
${ }^{30}$ As for first-time candidacies, we are only able to identify a subset of actual first-time victories for each position.

${ }^{31}$ We define an election to be held at the midterm of a given mandate if and only if it happens at least one year before the end (and one year after the beginning) of that mandate. Thus, for instance, the 2008 mayoral elections are midterm elections for candidates elected for the Senate in 2002.
} 
at midterm than successful candidacies corresponding to a first-time victory.

Table 1.3: Probability of Running at Midterm (\%)

\begin{tabular}{lcc}
\hline & \multicolumn{2}{c}{ Running at Midterm (\%) } \\
\cline { 2 - 3 } Position Won & Pooling Mandates & 1st-Time Mandates \\
\hline City Councilor & 2.13 & 0.90 \\
1st-Term Mayor & 0.15 & 0.00 \\
2nd-Term Mayor & 0.84 & \\
State Deputy & 17.28 & 15.53 \\
Federal Deputy & 16.67 & 13.33 \\
1st-Term Governor & 0.00 & $0.00 \dagger$ \\
2nd-Term Governor & $0.00 \dagger$ & $72.73 \dagger$ \\
Senator & 46.79 & 1.20 \\
\hline All & 2.68 & \\
\hline
\end{tabular}

The "Pooling Mandates" sample pools observations on successful candidacies related to elections for the Senate held prior to 2010 and to elections for other positions held prior to 2014. The "1st-Term Mandate" sample encompasses only those candidacies that amount to a first victory at the specified position by the corresponding individual. $\dagger$ indicates that the corresponding statistic is based on fewer than 30 observations.

\subsubsection{Incumbency Advantage and Office Turnover}

Next, we explore whether our data presents any indication of an association between incumbency status and an electoral advantage for candidates when running again. Table 1.4 provides the average rate of electoral success (i.e. the probability of being elected) achieved by some groups of candidates that partition the set of candidates eventually running for each position according to candidates' previous electoral attempts and corresponding performances. ${ }^{32}$ For candidates running for a given position, we consider the success rate among those whose last observed candidacy was filed for a different position and where the candidate lost, those who last ran for the same (currently contested) position and lost, those who last ran for another position and won, and those whose last observed candidacy was related to the same position and led to a victory. In these definitions, each candidate's last observed candidacy is restricted to having occurred no more than eight years before the considered candidacy; if a given candidacy is not preceded

\footnotetext{
${ }^{32}$ The corresponding statistics are obtained by pooling observations on candidacies across electoral years, so a given candidate running more than once in the period under analysis contributes with multiple observations.
} 
by another candidacy from the corresponding individual in that period, it is regarded as a first candidacy observed for that individual. The success rates among first observed candidacies are presented in the last column.

Table 1.4: Success Rate, by Position and Previous Candidacy Result

\begin{tabular}{lccccc}
\hline \multirow{2}{*}{$\begin{array}{l}\text { Position of } \\
\text { Candidacy }\end{array}$} & \multicolumn{2}{c}{ Result at Last Observed Candidacy (within 8 years) } & \multirow{2}{*}{$\begin{array}{c}\text { 1st Observed } \\
\text { Candidacy }\end{array}$} \\
\cline { 2 - 5 } $\begin{array}{c}\text { Lost Another } \\
\text { Position }\end{array}$ & $\begin{array}{c}\text { Lost Same } \\
\text { Position }\end{array}$ & $\begin{array}{c}\text { Won Another } \\
\text { Position }\end{array}$ & $\begin{array}{c}\text { Won Same } \\
\text { Position }\end{array}$ & \\
\hline City Councilor & 20.08 & 13.12 & 44.31 & 54.14 & 7.12 \\
Mayor & 18.43 & 40.78 & 33.32 & 55.34 & 26.78 \\
State Deputy & 3.34 & 8.18 & 11.15 & 70.51 & 1.87 \\
Federal Deputy & 3.88 & 5.95 & 18.03 & 70.55 & 2.25 \\
Governor & 4.78 & 21.05 & 21.94 & 64.44 & 0.93 \\
Senator & 8.31 & $20.69 \dagger$ & 35.33 & 58.06 & 3.43 \\
\hline All & 13.94 & 13.81 & 31.76 & 55.11 & 7.66 \\
\hline
\end{tabular}

The results are obtained upon pooling candidacies from 2006 to 2014 . $\dagger$ indicates that the corresponding statistic is based on fewer than 30 observations.

We observe that, generally speaking, candidacies preceded by a defeated candidacy to another position are less likely to succeed than those preceded by a losing candidacy to the same position, which might suggest that a candidate's chance of winning a given position depends on the number of times he or she has consecutively run for that position. Similarly, the latter class of candidacies is itself associated with lower success rates relative to candidacies preceded by a successful candidacy to another position. In turn, for each position, candidacies preceded by a winning candidacy to the same position present the highest success rates among all classes of candidacies. Candidates who are elected to a given position and whose following candidacy is filed for that same position are more than $50 \%$ likely to win again; the highest reelection rates are observed for state and federal deputies, who are more than $70 \%$ likely to win the same position again (conditional on running). In particular, we find that being elected for a given position is associated with higher success rates when running again for the same position as well as when running again for another position. Lastly, we see that first observed candidacies tend to present the lowest success rates across all classes of candidacies, which further reinforces the role of experience (in electoral races) in improving electoral results.

In light of the discussion above, it is also of interest to examine how the correlations of electoral success with incumbency status and with experience in running translate into office turnover rates or, more generally, into the extent of migration across offices. As shown in Table 1.5, candidates elected to all legislative positions (for which there are no 
restrictions on reelection) but that of senator most likely come from winning the same position at their last contested races. For any position, however, the proportion of elected candidates who were also elected for the same position at their last race is always lower than $50 \%$, which points to much lower office turnover rates than those observed for the U.S., for instance. Also, with the exception of city councils, all offices present a significant share of elected officials coming from incumbency of another office. For instance, more than $60 \%$ of candidates elected to a first (non-consecutive) term as governors and almost $50 \%$ of elected senators come from holding another office.

Table 1.5: Density of Elected Candidates Across Previous Candidacy Result

\begin{tabular}{lccccc}
\hline \multirow{2}{*}{ Position Won } & \multicolumn{3}{c}{ Result at Last Observed Candidacy (within 8 years) } & 1st Observed \\
\cline { 2 - 5 } & $\begin{array}{c}\text { Lost Another } \\
\text { Position }\end{array}$ & $\begin{array}{c}\text { Lost Same } \\
\text { Position }\end{array}$ & $\begin{array}{c}\text { Won Another } \\
\text { Position }\end{array}$ & $\begin{array}{c}\text { Won Same } \\
\text { Position }\end{array}$ & Candidacy \\
\hline City Councilor & 3.71 & 25.59 & 0.68 & 38.23 & 31.79 \\
1st-Term Mayor & 10.23 & 27.52 & 25.22 & 7.51 & 29.52 \\
State Deputy & 16.53 & 9.63 & 15.93 & 45.61 & 12.31 \\
Federal Deputy & 18.26 & 5.07 & 20.66 & 45.29 & 10.72 \\
1st-Term Governor & 18.18 & 14.55 & 61.82 & 3.64 & 1.82 \\
Senator & 23.85 & 5.50 & 48.62 & 16.51 & 5.50 \\
\hline All & 5.69 & 22.70 & 4.76 & 36.57 & 30.28 \\
\hline
\end{tabular}

The results are obtained upon pooling successful candidacies from 2006 to 2014 . $\dagger$ indicates that the corresponding statistic is based on fewer than 30 observations.

\subsubsection{Career Building: Common Trajectories}

In this section, we turn to illustrating the most common transitions between offices made by elected candidates during their political careers. More specifically, for candidates elected to a given office at some point in time and who also manage to win their following race, we explore which positions are most frequently won at such subsequent race. Similarly, for the pool of candidates elected for a given position at some point who had also won their previous race, we investigate which positions were more frequently won at the preceding race. ${ }^{33}$ These concepts allow us to develop a notion of which positions are the most common destinations of candidates elected to each office, as well as of these candidates' most frequent political "origins." A depiction of the most frequent trajectories derived from these specifications is presented in Figure 1.1 .34

\footnotetext{
${ }^{33}$ In that analysis, no restrictions are imposed is made regarding the interval between the two corresponding candidacies by each individual.

${ }^{34}$ When assessing the most frequent destinations from a given position, only (pooled) observations on candidacies for that position happening before a certain (position-specific) year are considered. This
} 
Figure 1.1: Inferred Trajectories - Absolute Frequencies

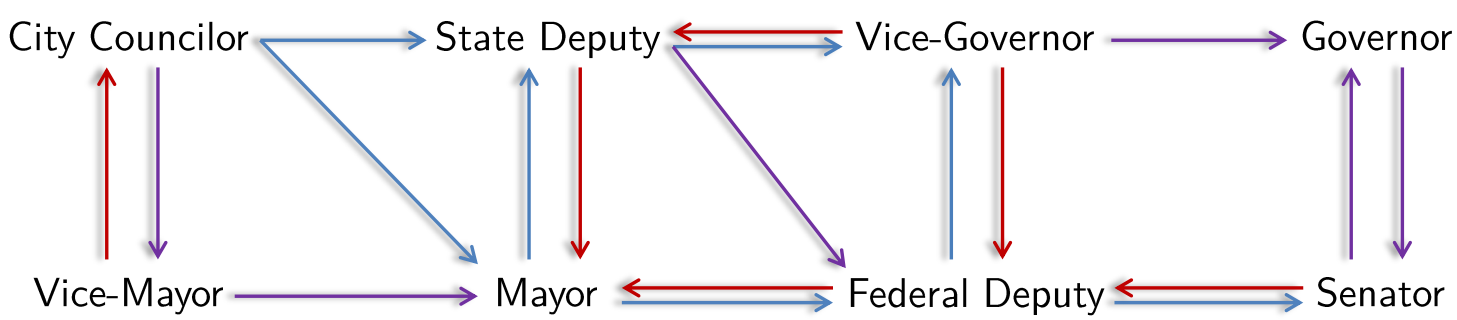

$\mathrm{A} \longrightarrow \mathrm{B}$ : Among those elected to position B that were also successful in their previous candidacy, A is one of the 3 most frequent previously occupied positions.

$\mathrm{A} \longrightarrow \mathrm{B}$ : Among those elected to position A that were also successful in their following candidacy, B is one of the 3 most frequent subsequently occupied positions.

$\mathrm{A} \longrightarrow \mathrm{B}: \mathrm{A} \longrightarrow \mathrm{B}$ and $\mathrm{A} \longrightarrow \mathrm{B}$

For each position, we consider the corresponding three most frequent destinations and the three most frequent origins, which are allowed to contain the considered position itself. However, the transition between a fixed position and a destination, or between an origin and the given position, must have occurred for at least $2 \%$ of the candidates ever elected for that position in order to be represented. Also, arrows indicating transitions to the same position are omitted for tidiness. A red arrow from position A to position $\mathrm{B}$ indicates that among candidates elected for position $\mathrm{A}$ that also won their following race, $\mathrm{B}$ is one of the most frequent positions of destination. Similarly, a light-blue arrow from A to B indicates that candidates elected for position B were more likely previously holding position A. Thus, we see that, for instance, candidates elected as vice-mayors who subsequently choose to migrate to another position tend to do so with regard to the position of city councilor. Also, candidates elected as state deputies who also won their previous race usually depart from the positions of city councilor or mayor, and candidates elected as vice-governors frequently migrate to the position of federal deputy as well as from that position. Moreover, a purple arrow from A to B indicates the combination of a red arrow and a light-blue arrow from the former to the latter. So, for instance, candidates elected as state deputies usually move to the position of federal deputy, and it

is done so to achieve a fairer comparison of the frequencies of all possible transitions. By considering observations on successful candidacies for governor from 2010, for instance, we would possibly understate the extent to which candidates elected for that position migrate to the position of mayor, since governors elected in 2010 would have to resign in order to run for mayor in 2012. Alternatively, the results achieved by including observations on candidacies for city councils from 2012 would probably understate the extent to which city councilors migrate to the position of mayor while overestimating the frequencies of transitions to positions at the state or federal levels Thus, for each position we only consider observations of candidacies before $2015-(x+2)$, where $x$ is the term duration associated with the corresponding position. For a similar reason, when exploring the most frequent positions of departure only observations on candidacies after 2004 are considered. 
is also true that candidates (holding any position) who migrate to the position of federal deputy frequently depart from the position of state deputy.

We note, however, that the above construction does not take into account differences in the number of seats between offices. In particular, one consequence is that positions associated with larger numbers of seats are more likely to appear as destinations from (and departures to) a given position than positions with lower numbers of seats. As an example, if the positions of governor and federal deputy were equally desired by incumbent state deputies, or even if the position of governor where slightly more coveted than that of federal deputy, the latter would probably be a destination more frequently than the former, since there are far fewer seats for governor than there are for federal deputy. Yet, we do not find that the position of city councilor (the one associated with the highest number of seats) is a frequent destination from (and departure to) all other positions, so that the representation in Figure 1.1 still reflects career paths that are influenced by some sort of hierarchy between positions. Nonetheless, we also present in Figure 1.2 an alternative depiction of relevant transitions between offices wherein the corresponding notion of frequency accounts for the number of seats for each position.

Figure 1.2: Inferred Trajectories - Relative Frequencies

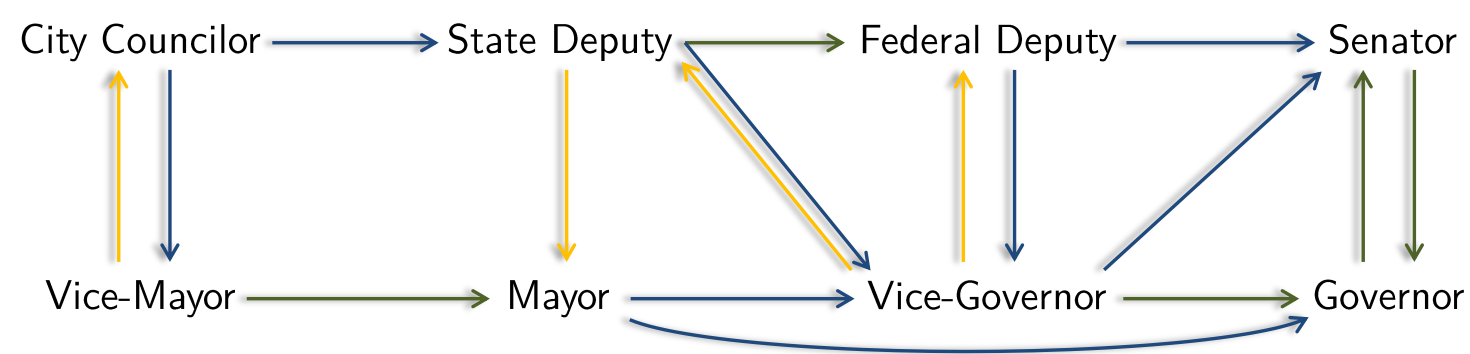
$\mathrm{A} \longrightarrow \mathrm{B}:$ Among those elected to position $\mathrm{B}, \mathrm{A}$ is one of the 3 most previously occupied positions relative to the number of seats.
$\mathrm{A} \longrightarrow \mathrm{B}$ : Among those elected to position A, B is one of the 3 most subsequently occupied positions relative to the number of seats.
$\mathrm{A} \longrightarrow \mathrm{B}: \mathrm{A} \longrightarrow \mathrm{B}$ and $\mathrm{A} \longrightarrow \mathrm{B}$

In that characterization, a yellow arrow from position $\mathrm{A}$ to position $\mathrm{B}$ indicates that among candidates elected to position $\mathrm{B}$, those that came from holding position A composed a relatively large proportion of the whole group of incumbents in position A compared to the proportions of incumbents in other positions that migrated to B. Additionally, a dark-blue arrow from A to B means that the share of seats for position B taken by candidates migrating from $\mathrm{A}$ is usually higher than the shares of seats for other positions taken by these same candidates. A green arrow represents the combination of a yellow and a dark-blue arrow of equal direction. We then observe that pairs of positions that 
displayed some kind of link under the previous setup tend to remain connected in that alternative arrangement. The most important difference is perhaps the fact that when accounting for the number of seats associated with each position, migrations from the position of mayor to those of vice-governor and governor now appear to be more relevant than the previously verified transitions between the positions of mayor and federal deputy.

Alternatively to exploring one-step transitions between offices, we also consider the entire political trajectories exhibited by candidates who managed to hold an elective position for most of the period observed in the data. For each of the positions of city councilor, mayor, state deputy, and federal deputy, Table 1.6 displays the most frequent paths followed by candidates who were elected in the first electoral year in the data corresponding to the given position (1998 for state and federal deputy, and 2000 for city councilor and mayor) and won subsequent elections sufficiently so as to have been out of office for no more than two consecutive years until 2016. For candidates elected for city council in 2000 and displaying such "almost-continuous" paths, we observe that almost $80 \%$ remain in the position of city councilor all the way through, whereas around $11 \%$ and $3.5 \%$ migrate at some point to the positions of vice-mayor and mayor, respectively (and keep being elected for these positions until the end of the observed time interval). For those candidates elected as mayors in 2000 and usually holding office, the most frequent migrations are made to the positions of state deputy and federal deputy; in addition, we note that eventually migrating to the position of state deputy and then back to mayor is also fairly common. Moreover, frequently elected candidates whose (observed) starting position was

Table 1.6: Common Trajectories of Candidates Usually Holding Office

\begin{tabular}{lccc}
\hline Position of & Trajectory & Frequency $(\%)$ & Obs. \\
\hline \multirow{2}{*}{ Cbserved Start } & City Councilor & 78.15 & 4,446 \\
& City Councilor $\rightarrow$ Vice-Mayor & 11.09 & 631 \\
& City Councilor $\rightarrow$ Mayor & 3.52 & 200 \\
Mayor & Mayor $\rightarrow$ State Deputy & 41.10 & 60 \\
& Mayor $\rightarrow$ Federal Deputy & 15.07 & 22 \\
& Mayor $\rightarrow$ State Deputy $\rightarrow$ Mayor & 9.59 & 14 \\
State Deputy & State Deputy & 50.70 & 144 \\
& State Deputy $\rightarrow$ Federal Deputy & 17.61 & 50 \\
& State Deputy $\rightarrow$ Mayor & 5.99 & 17 \\
Federal Deputy & Federal Deputy & 55.00 & 77 \\
& Federal Deputy $\rightarrow$ Senator & 10.71 & 15 \\
& Federal Deputy $\rightarrow$ Mayor & 7.14 & 10 \\
\hline
\end{tabular}


that of state deputy tend to stay at that position in $50 \%$ of the cases, and the most frequent transitions to other offices involve the positions of federal deputy and mayor. Similarly, more than half of the candidates elected as federal deputies in 1998 who were frequently elected subsequently remain in that position, and the two most common types of migration to other offices are to the positions of senator and mayor.

Next, we forgo the two-year tolerance regarding the continuity in elected candidates' mandates and explore the most common trajectories displayed by candidates who were elected in the first years observed in our data and who kept winning elections frequently so to have been out of office for no more than twelve consecutive months. That is, we consider the paths taken by candidates who were out of office only for the time between the end of a mandate in one year and the beginning of another mandate in the following year. The corresponding results are presented in Table 1.7. As expected, under such restrictions the most frequent paths for candidates starting as mayors are quite different than those discussed above, since "continuous" paths for mayors involve either migrating to the position of city councilor (arguably an inferior position) or standing down at midterm in order to run for general elections. In particular, the most common path concerning elected candidates first observed as mayors are based on migrating to the position of governor and then to that of senator. However, observations on continuous trajectories following incumbency as a mayor are scarce, which indicates a very low propensity among mayors to stand down. On the other hand, the most frequent trajectories following incumbency of other positions are the same as those presented in Table 1.6.

Table 1.7: Frequent Continuous Paths

\begin{tabular}{lccc}
\hline Position of & Continuous Trajectory & Frequency $(\%)$ & Obs. \\
\hline \multirow{3}{*}{ City Councilor } & City Councilor & 80.02 & 4,446 \\
& City Councilor $\rightarrow$ Vice-Mayor & 11.07 & 615 \\
& City Councilor $\rightarrow$ Mayor & 3.58 & 199 \\
Mayor & Mayor $\rightarrow$ Governor $\rightarrow$ Senator & 20.00 & 3 \\
& Mayor $\rightarrow$ State Deputy $\rightarrow$ Federal Deputy & 13.33 & 2 \\
& Mayor $\rightarrow$ State Deputy & 13.33 & 2 \\
State Deputy & State Deputy & 59.18 & 87 \\
& State Deputy $\rightarrow$ Federal Deputy & 22.45 & 33 \\
Federal Deputy & State Deputy $\rightarrow$ Mayor & 6.80 & 10 \\
& Federal Deputy & 60.00 & 48 \\
& Federal Deputy $\rightarrow$ Senator & 16.25 & 13 \\
& Federal Deputy $\rightarrow$ Mayor & 7.50 & 6 \\
\hline
\end{tabular}




\subsubsection{Party Switching}

Lastly, we explore the issue of party loyalty by candidates through measuring the proportion of candidates who change their affiliations between two consecutive candidacies. In doing so, we also investigate whether there seems to exist some connection between being elected and the propensity to switch parties before running again. Table 1.8 below provides the corresponding statistics for candidates running for each main position and according to their previous electoral results.

For candidates running for city council, for instance, we observe that around $30 \%$ of those who won that same position at their last contested race where affiliated to a different party back then. On the other hand, more than $55 \%$ of candidates running for the position of city councilor who lost that position at their previous race switched their affiliations between the two races. Similarly, around $41 \%$ of candidates for city council who won a different position at their previous race did so under a different party, whereas almost $44 \%$ of those who last ran for a different position and lost changed their affiliations between races.

Table 1.8: Party Switching (\%), by Previous Candidacy Status

\begin{tabular}{lcccc}
\hline \multirow{2}{*}{$\begin{array}{l}\text { Position of } \\
\text { Candidacy }\end{array}$} & \multicolumn{4}{c}{ Result at Last Observed Candidacy (within 8 years) } \\
\cline { 2 - 5 } & $\begin{array}{c}\text { Lost Another } \\
\text { Position }\end{array}$ & $\begin{array}{c}\text { Lost Same } \\
\text { Position }\end{array}$ & $\begin{array}{c}\text { Won Another } \\
\text { Position }\end{array}$ & $\begin{array}{c}\text { Won Same } \\
\text { Position }\end{array}$ \\
\hline City Councilor & 43.94 & 55.46 & 40.86 & 30.37 \\
Mayor & 46.04 & 38.90 & 36.08 & 30.76 \\
State Deputy & 35.71 & 52.63 & 25.57 & 28.13 \\
Federal Deputy & 35.99 & 45.39 & 23.19 & 22.47 \\
Governor & 25.84 & 21.05 & 19.35 & 15.56 \\
Senator & 22.36 & $20.69 \dagger$ & 21.33 & 22.58 \\
\hline All & 40.26 & 54.88 & 32.41 & 30.33 \\
\hline
\end{tabular}

See notes to Table 1.4

As a general matter, we find that the incidence of party switching in Brazilian politics is usually quite high, regardless of candidates' electoral performances, which suggests that ideological stances are not very strong among candidates and incumbents. Also, we see that among candidates running for each given position, those who won the same position at their preceding race are usually less likely to have switched parties than those who lost that position at the last contested race. Similarly, among candidates running for a given position, those who won another position in their last races are less prone to 
switching parties than those who lost another position in their preceding races. In other words, the circumstance of being elected appears to be related to a lower probability of candidates switching their affiliations, which itself suggests that considerations of party loyalty by candidates may be at least partly guided by opportunistic reasons rather than by identification with a party's principles.

Moreover, we note in particular that the differences between the probabilities associated with the two groups of candidates who ran for the same position at the preceding race are especially striking when we consider candidates running for positions under proportional representation rules (i.e. city councilor, state deputy, and federal deputy). In those cases, candidates who lost the same position at their last disputed race are almost twice as likely to have switched parties than those who won the same position in the preceding race. Since the electoral fate of a candidate running under proportional representation systems is relatively more dependent upon the performance of the party as a whole (and not only based on that of the candidate alone), we conjecture that party switching may be particularly motivated by candidates attributing their defeats to poor performances by their parties. On the other hand, it might also be the case that some low-performing candidates are excluded from their parties' future lists of candidates, so running again would require becoming affiliated to a different (and perhaps more lenient) party.

\subsection{Empirical Strategy}

The estimation of causal effects of incumbency traditionally involves diverse methodological challenges that, despite being well known by now, are not always properly dealt with (even in recent studies) and remain non trivial in certain contexts. Since incumbents of elective positions hold that status as a result of performing better than (at least some of) their competitors in previous elections, it should come as no surprise that they are able to maintain whatever idiosyncratic traits granted them such past success and to keep exhibiting some advantages relative to defeated candidates, especially when an electoral advantage (in future elections) is considered. In other words, a causal interpretation of a relationship between incumbency status and electoral performance is often precluded by confounding factors such as the fact that incumbents tend to be higher quality candidates and that decisions on political careers (in particular, on running again) are made strategically according to candidates' electoral prospects.

To circumvent those issues, our analysis of the causal effects of incumbency on "crossoffice" career choices and electoral success relies on a regression discontinuity design. This approach exploits the fact that while political agents may surely influence election results 
(e.g. through campaign activities and vote-buying), they do not possess complete control over electoral outcomes. A random chance component of the vote share, for instance, may be illustrated by the weather on election day or by the occurrence of traffic jams. Thus, inherent uncertainty in the final vote count is usually a plausible notion. ${ }^{35}$

For a given elective position under a simple plurality rule (e.g. mayoral elections in small constituencies), let the vote share margin of victory $M_{i, l, c, t}$ equal the vote share obtained by candidate $i$ from coalition $l$-running in an election at time $t$ in constituency $c$ minus the vote share attributed to $i$ 's best-performing adversary (in an election at $t$ in constituency $c$ ); the presence of coalition index $l$ is moot at this point, but will become important in unifying the notation shortly. Thus, if $i$ is the winning candidate, $M_{i, l, c, t}$ will be equal to $i$ 's vote share minus the vote share of the corresponding second-place candidate. Alternatively, if $i$ is any losing candidate, $M_{i, l, c, t}$ will be equal to $i$ 's vote share minus that of the elected candidate. Also, let $I_{i, l, c, t}$ denote the incumbency status of candidate $i$ from coalition $l$ following the election at $t$ in constituency $c$. Aside from candidates tied in first place, each candidate's incumbency status is completely determined by his or her corresponding vote share margin $M_{i, l, c, t}$ and may be described in the following manner: $I_{i, l, c, t}=1$ if $M_{i, l, c, t}>0$ and $I_{i, l, c, t}=0$ if $M_{i, l, c, t}<0$; This discontinuous deterministic relationship is the core of regression discontinuity designs regarding incumbency effects. Moreover, the same relationship and the same definitions above also apply to runoff elections decided in the first round.

For proportional representation elections, on the other hand, the analogous definitions of vote share margins and incumbency status indicators would not lead to the same relationship between these two variables, at least in the Brazilian case. As explained in Section 1.2, under those rules seats are first distributed to parties or coalitions (according to their total number of votes), and only then awarded to the best-ranking candidates within each winning party/coalition. In particular, this means that a low-performing candidate may be elected whereas a better-performing candidate (running at the same time and in the same constituency) from another party/coalition is not. Nonetheless, we are still able to define an adequate vote share margin for candidates running for office under a proportional representation system by comparing candidates within the same coalition. In what follows, we take the same approach as that of Boas and Hidalgo (2011). Formally, let $s_{l}$ denote the number of seats won by coalition $l$ (constituency and time indexes are omitted for clarity) and let $v_{i, l}$ be the vote share received by candidate $i$ from coalition $l$ (relative to the corresponding district). Without loss of generality, we normalize candidate index $i$ to denote each candidate's intracoalition rank. Then, candidate $i$ is elected if and only if $i \leq s_{l}$. In this setting, candidate $i$ 's vote share

\footnotetext{
${ }^{35}$ Exceptions include cases of electoral fraud, for instance.
} 
margin, $M_{i, l}$, may be defined as:

$$
M_{i, l}= \begin{cases}v_{i, l}-v_{s_{l}+1, l} & \text { if } i \leq s_{l} \\ v_{i, l}-v_{s_{l}, l} & \text { if } i>s_{l}\end{cases}
$$

That is, if $i$ is an elected candidate, $i$ 's vote share margin will be equal to his or her vote share minus that of his or her best-performing losing adversary from the same coalition. Similarly, if $i$ is a losing candidate, $i$ 's vote share margin will be his or her vote share minus that of his or her worst-performing winning adversary from the same coalition. This definition captures the idea that the vote share margin reflects, all else being equal, the share of votes that, once won (lost) by a losing (winning) candidate, would have changed his/her incumbency status. Thus, under this setting we once more have that $I_{i, l, c, t}=1$ if $M_{i, l, c, t}>0$ and $I_{i, l, c, t}=0$ if $M_{i, l, c, t}<0 .{ }^{36}$ Moreover, the definitions of the vote share margin both for plurality elections (decided in a single round) and for elections under proportional representation rules intuitively imply that the random choice component of the vote share would play a more decisive role in determining election results the smaller the candidates' vote share margins. In other words, the incumbency status of candidates that barely won or barely lost a certain election is expected to be as good as random, rather than resulting from differences in background characteristics (which would bias our estimates of incumbency effects).

As well established in the RD design literature (e.g. Lee (2008)), the discontinuous nature of the (deterministic) relationship between incumbency (treatment) status and vote share margin coupled with continuity assumptions on the density of the vote share margin allows the estimation of causal incumbency effects at $M_{i, l, c, t}=0$. The treatment effect of narrowly winning a given elective position on outcome $Y_{i, l, c, t}$ is given by:

$$
T E=E\left[Y_{i, l, c, t}(1) \mid M_{i, l, c, t}=0\right]-E\left[Y_{i, l, c, t}(0) \mid M_{i, l, c, t}=0\right]
$$

where $Y_{i, l, c, t}(1)$ and $Y_{i, l, c, t}(0)$ denote the outcome of interest for candidate $i$ from coalition $l$ (once again, coalition index $l$ is moot for elections under plurality rules) in constituency $c$ and election year $t$ when $i$ is a winner and a loser of the given position, respectively.

Estimation of the treatment effects on each of the outcomes of interest follows the guidelines set by Imbens and Lemieux (2008) and Imbens and Kalyanaraman (2012), and is performed non-parametrically by local linear regression with a sample of candidates run-

\footnotetext{
${ }^{36}$ For all positions, ties in vote shares are broken by crediting older candidates with higher rankings. We then drop candidates with a zero vote margin from the sample, as their inclusion would potentially introduce an age imbalance among close winners and close losers.
} 
ning for each position. This amounts to estimating regressions of $Y_{i, l, c, t}$ on $M_{i, l, c, t}$ for each side of the discontinuity by using only data satisfying $M_{i, l, c, t} \in[-h, 0)$ and $M_{i, l, c, t} \in(0, h]$, where $h$ is the bandwidth. Also, a rectangular kernel is used in the estimation, as suggested by Lee and Lemieux (2010). In this case, our local linear regression estimates are equivalent to OLS estimates of the equation

$$
Y_{i, l, c, t}=\alpha+\beta I_{i, l, c, t}+\gamma M_{i, l, c, t}+\delta M_{i, l, c, t} I_{i, l, c, t}+\epsilon_{i, l, c, t}
$$

where $\beta$ is the treatment effect. For each considered elective position, the corresponding sample pools observations of candidates running for that position in the 1998-2010 period, and standard errors are clustered at the constituency level.

A critical point is the choice for the bandwidth value, $h$. The narrower the window used in the estimation, the less precise should be the estimates, as the number of observations is reduced. On the other hand, the "as good as random" assumption - and, thus, a smaller bias - is more likely to be valid for smaller windows around the zero vote share margin cutpoint. Determination of $h$ follows the procedure suggested by Imbens and Kalyanaraman $(2012)$ for an optimal bandwidth choice. ${ }^{37}$ The resulting bandwidth (IKBW, henceforth) is fully data-driven and consequently different for each outcome variable $Y$. To reinforce the local intuition of the RD design, the largest possible IKBW is capped at $10 \%$ of the vote share for elections under simple plurality rules, and at $0.4 \%$ for elections under proportional representation rules. To probe the robustness of the results to bandwidth choices, we also estimate each treatment effect using discontinuity samples defined by $h=1 \%, h=5 \%$, and $h=10 \%$ for elections based on plurality rules, and $h=0.05 \%$, $h=0.1 \%$, and $h=0.2 \%$ for proportional representation elections.

\subsection{Estimation Results}

Our investigation of the electoral effects of holding office is centered on incumbency as a city councilor, as a mayor, as a state deputy, and as a federal deputy. In particular, when exploring the effects of incumbency as a mayor, we mostly focus on candidates who are running for a first term (i.e. those who are not incumbent mayors), whereas incumbent mayors assume a secondary role. This is motivated by the fact that mayors running for a second consecutive term are subjected to different institutional rules (due to term limits) that probably affect their career decisions; thus, considering them without distinction relative to candidates who are not incumbent mayors would possibly confound

\footnotetext{
${ }^{37}$ The bandwidth choice proposed by Imbens and Kalyanaraman $(2012)$ is optimal in the sense of minimizing (an approximation of) the mean squared error of the corresponding estimator.
} 
our analysis. We also restrict the study to elections that were decided in a single round, since any definition of vote share margins of victory for elections decided after two rounds would arguably lead either to a poor measure of candidate comparability or to an unclear, non-deterministic relationship with incumbency status. We withdraw other elective positions from consideration either because they do not precisely correspond to officeholders (e.g. vice-mayor), or because they are associated with a relatively low number of seats (e.g. senator) and, hence, few observations in the data, which would not produce sufficient statistical power for RD estimates to be meaningful.

Before reporting the main results of this section, we perform some robustness checks on the adequacy of our RD approach. To assess the validity of the "as good as random" assumption, we evaluate the continuity of the density of the forcing variable (i.e. the vote share margin) at the zero cutpoint using the test suggested by McCrary (2008). Evidence of a significant discontinuity at that cutpoint could indicate, for instance, that some candidates are able to manipulate their final vote shares to an extent sufficient to change their incumbency status. In that case, incumbency could no longer be seen as a (quasi-) random treatment, even among candidates who barely won or barely lost. However, as shown in Figure 1.B1 in the appendices, the null hypothesis of continuity of that density is not rejected for any position.

Also, to obtain further assurance that candidates above and below the discontinuity threshold do not differ on important background characteristics that could affect their incumbency status, we estimate the effects of taking office on pre-determined demographic and political variables. Tables 1.C2 1.C5 in the appendices present the results for each position. As expected, the corresponding estimates tend to be statistically insignificant overall. For the positions of city councilor, (first-term) mayor, and state deputy, estimates for each given outcome are statistically significant at the $5 \%$ level in at most one of the four specifications discussed above (i.e. using the IKBW and three other discontinuity samples). ${ }^{38}$ On the other hand, our samples of federal deputies who barely won or lost display a higher degree of imbalance by treatment status in those characteristics, and for five variables the estimates are statistically significant at the $5 \%$ level in two or more specifications. The effects of incumbency as a federal deputy are then reestimated after introducing these variables as controls in model (1.2). The corresponding estimates are displayed in Table 1.C6 in the appendices and show us that our results are not significantly altered after accounting for imbalance in those dimensions. ${ }^{39}$

\footnotetext{
${ }^{38}$ It is important to note that, since we do not restrict our samples of barely winners/losers only to the worst elected candidate and the best-performing loser (within the corresponding coalition, in the case of proportional representation elections), the balance found for variables determined at the constituency level is not achieved by construction.

${ }^{39}$ As another robustness check, we also estimated the main effects of incumbency of proportional representation positions (and corresponding balance statistics) using an inflated vote share margin that
} 
We now proceed to the presentation and discussion of our main results. For each of the four considered positions, we first analyze the impact of incumbency on whether a candidate runs for any position in the next four years, and on whether a candidate wins any position in the next four years, unconditional on running again in that period; that is, a candidate who does not run in a given subsequent election is coded as a loser in that election. These outcomes intuitively translate into candidates' desire to pursue (or remain in) a political career in general, as well as into their success in doing so; in particular, this unconditional measure of victory may be interpreted as the probability that a candidate will be holding an elective office in the near future. In addition, the consideration of incumbency effects on future candidacy may shed some light on the likelihood that the corresponding effects on winning would still be verified after conditioning on running (instead of simply reflect some kind of selection into candidacy); incumbency effects on winning conditional on future candidacy are considered in the next section.

Then, to obtain a better understanding of the extent to which incumbency affects the degree of (desired) migration across offices, we break down each of these effects into the impacts of incumbency on whether a candidate runs for, and wins, the same position (in four years), and on whether a candidate runs for, and wins, another position (within four years). Graphical counterparts to the corresponding estimation results are provided in the appendices. We also explore whether the latter effects are contingent on certain political and demographic dimensions that may arguably perform an important role in candidates' electoral success and career choice; namely, we investigate the presence of effect heterogeneity according to the size of the constituency's electorate, the degree of electoral competition at $t$ (measured by the ratio of the number of candidates to the number of seats), and whether a candidate has recent political experience (defined here as having won any election in the past four years). ${ }^{40}$ The dimensions of electorate size and political experience are likely to be linked with the amount of resources that incumbents are able to use to win again; for instance, incumbents running in large constituencies might have higher campaign budgets, and experienced incumbents are likely to have more coverage in the media. Also, as argued by Leoni et al. (2004), for example, incumbents' choices of which office to run for may be affected by the degree of competition associated with the held position; in that case, one might imagine that incumbents who barely

punishes candidates whose margin of victory is large relative to their vote share (e.g., winning by $0.001 \%$ of the total votes in the constituency while having received only $0.01 \%$ of those votes). This inflated margin was calculated by multiplying the original vote share margin, $M_{i, l}$ (omitting constituency and time indexes), by $v_{i, l} /\left(v_{i, l}-M_{i, l}\right)$ for winning candidates, and by $\left(v_{i, l}-M_{i, l}\right) / v_{i, l}$ for losing candidates. Main results under such inflated margin were very similar to those obtained under the original margin. The balance in pre-determined characteristics was slightly worse for the position of city councilor, and slightly better for federal deputies. The corresponding estimates are available from the author upon request.

${ }^{40}$ However, we restrict that discussion to those instances where evidence on effect heterogeneity is found to be statistically significant for most specifications. 
won after facing great competition are more likely to subsequently run for a less fiercely contested position.

Lastly, in evaluating incumbency effects on the configuration of career paths, we choose to adopt a somewhat agnostic stance regarding the establishment of a hierarchical structure around the diverse positions; some exceptions are considered in the next sections. In particular, unlike Samuels $(1998,2000)$, we do not as a general rule assume that federal deputies (for instance) value extra-congressional positions (such as that of mayor) more highly. At this point, instead of defining subsets of "higher" and "lower" offices relative to each considered position (and which transitions between offices should be seen as "progressive" or "regressive"), we explore the impacts of incumbency of each position on running for and on winning each of the other three positions within four years. ${ }^{41}$

\subsubsection{City Councilor}

Panel A of Table 1.9 presents our main estimates of the impact of being elected as a city councilor on whether the candidate runs again within four years and whether the candidate wins another election within four years. Similarly, Panel B of the same table displays the effect of incumbency of that position on whether the candidate runs for the same position, whether the candidate wins the same position, whether the candidate runs for another position, and whether the candidate wins another position. The "Loser Mean" column presents estimated values of the averages of the dependent variables for candidates who lost with a zero vote share margin; technically, each of those values corresponds to the estimated constant term in model (1.2) using the IKBW, which is in turn reported in column "IKBW" along with the sample size of the optimal bandwidth specification (in brackets).

Firstly, our results indicate that candidates for the position of city councilor who narrowly won are around 10-11 percentage points (p.p.) more likely to run again within four years than candidates who narrowly lost. Such a higher propensity to run again stemming from incumbency is also verified when we separately consider the effects on running for the same position and for another position. The point estimates obtained by employing the optimal bandwidth (column (1)) suggest that being elected as a city councilor is associated with a 10.27 p.p. increase in the probability of running again for the same position and a 3.3 p.p. increase in the probability of running for another position. Although the latter effect indicates a lower magnitude, it is actually sizeable given that only $5.42 \%$ of candidates

\footnotetext{
${ }^{41}$ We have also explored the effects of incumbency of a given position on running for and on winning each of the other main positions in an interval of six years. The corresponding results are qualitatively very similar to those corresponding to intervals of four years, and are omitted for brevity.
} 
who narrowly lost run for another position within four years, and that other positions are related to far lower numbers of seats.

Table 1.9: City Councilor - Incumbency Effects on Candidacy/Victory

\begin{tabular}{|c|c|c|c|c|c|c|}
\hline & $\begin{array}{l}\text { Loser } \\
\text { Mean }\end{array}$ & $\begin{array}{c}\text { IKBW } \\
\{\text { obs }\}\end{array}$ & $(1)$ & $(2)$ & $(3)$ & $(4)$ \\
\hline \multicolumn{7}{|l|}{ Panel $A$} \\
\hline Candidacy w/in 4 years $(\%)$ & 73.36 & $\begin{array}{c}0.259 \\
\{59,056\}\end{array}$ & $\begin{array}{c}11.35^{* * *} \\
(0.77)\end{array}$ & $\begin{array}{c}9.69 * * * \\
(1.92)\end{array}$ & $\begin{array}{c}10.75^{* * *} \\
(1.31)\end{array}$ & $\begin{array}{c}11.57^{* * *} \\
(0.83)\end{array}$ \\
\hline Winning w/in 4 years $(\%)$ & 32.98 & $\begin{array}{c}0.208 \\
\{46,431\}\end{array}$ & $\begin{array}{c}-3.87 * * * \\
(1.00)\end{array}$ & $\begin{array}{c}-5.19 * * \\
(2.34)\end{array}$ & $\begin{array}{c}-5.67^{* * * *} \\
(1.50)\end{array}$ & $\begin{array}{c}-3.90 * * * \\
(1.01)\end{array}$ \\
\hline \multicolumn{7}{|l|}{ Panel B } \\
\hline $\begin{array}{l}\text { Candidacy for the same } \\
\text { pos. w/in } 4 \text { years }(\%)\end{array}$ & 70.16 & $\begin{array}{c}0.234 \\
\{52,803\}\end{array}$ & $\begin{array}{c}10.27^{* * * *} \\
(0.88)\end{array}$ & $\begin{array}{c}8.07 * * * \\
(2.13)\end{array}$ & $\begin{array}{c}9.12^{* * *} \\
(1.38)\end{array}$ & $\begin{array}{c}10.26^{* * *} \\
(0.88)\end{array}$ \\
\hline $\begin{array}{l}\text { Winning the same } \\
\text { pos. w/in } 4 \text { years }(\%)\end{array}$ & 32.02 & $\begin{array}{c}0.207 \\
\{46,192\}\end{array}$ & $\begin{array}{c}-4.32^{* * *} \\
(0.99)\end{array}$ & $\begin{array}{c}-5.25^{* *} \\
(2.33)\end{array}$ & $\begin{array}{c}-5.87^{* * * *} \\
(1.48)\end{array}$ & $\begin{array}{c}-4.25^{* * * *} \\
(1.00)\end{array}$ \\
\hline $\begin{array}{l}\text { Candidacy for another } \\
\text { pos. w/in } 4 \text { years }(\%)\end{array}$ & 5.42 & $\begin{array}{c}0.354 \\
\{83,544\}\end{array}$ & $\begin{array}{c}3.30^{* * *} \\
(0.53)\end{array}$ & $\begin{array}{c}6.12^{* * *} \\
(1.32)\end{array}$ & $\begin{array}{c}4.66^{* * *} \\
(0.84)\end{array}$ & $\begin{array}{c}3.79^{* * *} \\
(0.58)\end{array}$ \\
\hline $\begin{array}{l}\text { Winning another } \\
\text { pos. w/in } 4 \text { years }(\%)\end{array}$ & 0.84 & $\begin{array}{c}0.400 \\
\{96,054\}\end{array}$ & $\begin{array}{c}0.50^{* * *} \\
(0.14)\end{array}$ & $\begin{array}{c}0.06 \\
(0.46)\end{array}$ & $\begin{array}{c}0.18 \\
(0.30)\end{array}$ & $\begin{array}{l}0.38^{*} \\
(0.20)\end{array}$ \\
\hline Bandwidth & & & IKBW & $0.05 \%$ & $0.1 \%$ & $0.2 \%$ \\
\hline Observations & & & - & 9,738 & 20,949 & 44,546 \\
\hline
\end{tabular}

Standard errors (in parenthesis) are robust to clustering at the constituency level. The unit of observation is a candidate, pooling election years from 1998 to 2010. Each figure in columns (1)-(4) is from a separate local linear regression with the specified bandwidth. The IKBW column provides the optimal bandwidth according to Imbens and Kalyanaraman (2012), with the associated number of observations in brackets. "Loser Mean" is the estimated value of the dependent value for a defeated candidate with a zero vote share margin, according to the IKBW specification. ${ }^{*}, * *$, and $* * *$ indicate significance at the $10 \%, 5 \%$ and $1 \%$ levels, respectively.

Moreover, we find that incumbency as a city councilor has a significant negative effect on the probability of winning: narrow winners are around 4-5 p.p. less likely than narrow losers to win any position within four years. Interestingly, our results show that this composite effect is driven by a negative incumbency effect (of similar size) on the probability of winning the same position, while the estimated effect on the probability to win another position is always positive (but usually statistically insignificant). In particular, given the positive effects on running discussed above, this finding suggests that incumbency must have a negative effect on winning even among those candidates who end up running again for the same position. Aside from the effect on winning another position, all the other effects are statistically significant at the $5 \%$ level and present similar magnitudes across specifications. Also, the results presented in Table 1.C7 (in the appendices) show that the positive effect of being elected for city council on candidacy for another position applies separately to running for mayor, for state deputy, and for federal deputy; the corresponding effects on winning each of these positions within four years are once again usually 
statistically insignificant.

We then turn to investigating whether the effects of incumbency are more relevant for some groups of candidates. Panels A and B of Table 1.10 provide estimates of the effect on winning the same position in four years obtained by alternately considering the subsample of candidates without recent political experience and the subsample of candidates with recent political experience, respectively. These results show that the significant negative effect previously found is restricted to candidates without recent experience, whereas the corresponding effect for experienced candidates is always statistically insignificant, smaller in magnitude, and has different signs across our four specifications. Among candidates without recent experience, our results suggest that barely winners are 8-11 p.p. (around $25 \%$ ) less likely than barely losers to win the same position after four years. A tentative explanation is that the lack of political experience not only prevents (barely) elected candidates from taking full advantage of office in order to beat their adversaries (including barely losers who run again for the same position), but also leads to the implementation of relatively unpopular and electorally harmful policies; thus, given the decision to run again, losers are likely to become better evaluated than their elected counterparts. The null hypothesis of equality in the treatment effects for the two groups of candidates is rejected in three out of four specifications.

Table 1.10: City Councilor - Incumbency Effects by Recent Political Experience

\begin{tabular}{lcccccc}
\hline \multicolumn{1}{l}{$\begin{array}{c}\text { Loser } \\
\text { Mean }\end{array}$} & $\begin{array}{c}\text { IKBW } \\
\text { \{obs }\}\end{array}$ & $(1)$ & $(2)$ & $(3)$ & $(4)$ \\
\hline $\begin{array}{l}\text { Panel A: Candidates without Recent Experience } \\
\text { Winning the same }\end{array}$ & 38.34 & 0.259 & $-8.29^{* * *}$ & $-9.51^{* *}$ & $-11.42^{* * *}$ & $-8.66^{* * *}$ \\
pos. w/in 4 years (\%) & & $\{24,731\}$ & $(1.76)$ & $(3.78)$ & $(2.30)$ & $(1.67)$ \\
Observations & & - & 3,901 & 8,484 & 18,455 \\
Panel B: Candidates with Recent Experience & & & & \\
Winning the same & 30.63 & 0.396 & 1.71 & -4.15 & -0.74 & -0.05 \\
pos. w/in 4 years (\%) & & $\{16,172\}$ & $(1.49)$ & $(5.17)$ & $(3.23)$ & $(2.15)$ \\
Observations & & & - & 1,876 & 3,967 & 8,196 \\
Test of Equality in TE (p-value) & & & 0.000 & 0.400 & 0.006 & 0.001 \\
Bandwidth & & & IKBW & $0.05 \%$ & $0.1 \%$ & $0.2 \%$ \\
\hline
\end{tabular}

All notes to Table 1.9 apply, except that only observations from 2002 to 2010 are used, since data on recent political experience is missing for candidates running in 1998-2000.

We also explore whether the effects of incumbency are heterogeneous among candidates running in municipalities with different electorate sizes. Panels A and B of Table 1.11 present the effects of incumbency on the probability of running for another position, estimated by dividing the sample into two categories: municipalities with electorate sizes below and above the median in the corresponding electoral year. Similarly, Panels A 
Table 1.11: City Councilor - Incumbency Effects by Electorate Size 1

\begin{tabular}{|c|c|c|c|c|c|c|}
\hline & $\begin{array}{l}\text { Loser } \\
\text { Mean }\end{array}$ & $\begin{array}{c}\text { IKBW } \\
\{\text { obs }\}\end{array}$ & $(1)$ & $(2)$ & $(3)$ & $(4)$ \\
\hline \multicolumn{7}{|c|}{ Panel A: Electoral Units with Below-Median Electorate } \\
\hline $\begin{array}{l}\text { Candidacy for another } \\
\text { pos. w/in } 4 \text { years }(\%)\end{array}$ & 2.88 & $\begin{array}{c}0.400 \\
\{26,094\}\end{array}$ & $\begin{array}{c}0.48 \\
(0.47)\end{array}$ & $\begin{array}{l}-1.38 \\
(3.00)\end{array}$ & $\begin{array}{c}0.15 \\
(1.31)\end{array}$ & $\begin{array}{c}0.11 \\
(0.74)\end{array}$ \\
\hline Observations & & & - & 2,202 & 5,586 & 12,457 \\
\hline \multicolumn{7}{|c|}{ Panel B: Electoral Units with Above-Median Electorate } \\
\hline $\begin{array}{l}\text { Candidacy for another } \\
\text { pos. w/in } 4 \text { years }(\%) \\
\text { Observations }\end{array}$ & 6.14 & $\begin{array}{c}0.400 \\
\{69,960\}\end{array}$ & $\begin{array}{c}4.36^{* * *} \\
(0.70) \\
-\end{array}$ & $\begin{array}{c}6.66^{* * *} \\
(1.42) \\
7.536\end{array}$ & $\begin{array}{c}5.52^{* * *} \\
(0.98) \\
15.363\end{array}$ & $\begin{array}{c}4.91^{* * *} \\
(0.72) \\
32.089\end{array}$ \\
\hline $\begin{array}{l}\text { Test of Equality in TE } \\
\text { (p-value) }\end{array}$ & & & 0.000 & 0.015 & 0.001 & 0.000 \\
\hline Bandwidth & & & IKBW & $0.05 \%$ & $0.1 \%$ & $0.2 \%$ \\
\hline
\end{tabular}

All notes to Table 1.9 apply.

and B of Table 1.12 report the estimated effects on winning another position for each of these subsamples. For both of these outcomes, our findings suggest that the corresponding positive effects displayed in Table 1.9 are actually restricted to municipalities with relatively large electorate sizes. For candidates running in municipalities with smaller electorates, incumbency effects on running for and on winning another position have smaller magnitudes and are statistically insignificant. At the $5 \%$ level, the null hypothesis of equality in the effect on running for another position is rejected in all occasions, and the null hypothesis of equality in the effect on winning another position is rejected in two specifications. Since election for any other position usually involves the need to obtain a significantly higher number of votes than that necessary for being elected for city council (either because the number of seats is smaller, as in elections for mayor, or because the corresponding constituency is the state rather than the municipality), these results are consistent with the view that city councilors elected in large municipalities tend to feel better able to win other positions (and are more prone to run for them), as they have already been elected with a large number of votes. For candidates running for the position of city councilor in relatively large municipalities, our results obtained under the optimal bandwidth suggest incumbency is associated with a 4.36 p.p. increase in the probability of running for another position (over a $6.14 \%$ loser mean), and with a 0.68 p.p. increase in the probability of winning another position within four years (over a $0.79 \%$ loser mean).

In addition, we find that the degree of electoral competition at the city council election may influence the importance of winning that election in the decision to run for another 
Table 1.12: City Councilor - Incumbency Effects by Electorate Size 2

\begin{tabular}{|c|c|c|c|c|c|c|}
\hline & $\begin{array}{l}\text { Loser } \\
\text { Mean }\end{array}$ & $\begin{array}{l}\text { IKBW } \\
\{\mathrm{obs}\}\end{array}$ & $(1)$ & $(2)$ & $(3)$ & $(4)$ \\
\hline \multicolumn{7}{|c|}{ Panel A: Electoral Units with Below-Median Electorate } \\
\hline $\begin{array}{l}\text { Winning another } \\
\text { pos. w/in } 4 \text { years }(\%)\end{array}$ & 0.97 & $\begin{array}{c}0.400 \\
\{26,094\}\end{array}$ & $\begin{array}{c}0.03 \\
(0.27)\end{array}$ & $\begin{array}{l}-3.06 \\
(1.99)\end{array}$ & $\begin{array}{l}-0.89 \\
(0.77)\end{array}$ & $\begin{array}{l}-0.53 \\
(0.42)\end{array}$ \\
\hline Observations & & & - & 2,202 & 5,586 & 12,457 \\
\hline \multicolumn{7}{|c|}{ Panel B: Electoral Units with Above-Median Electorate } \\
\hline $\begin{array}{l}\text { Winning another } \\
\text { pos. w/in } 4 \text { years }(\%)\end{array}$ & 0.79 & $\begin{array}{c}0.400 \\
\{69,960\}\end{array}$ & $\begin{array}{c}0.68^{* * *} \\
(0.16)\end{array}$ & $\begin{array}{c}0.30 \\
(0.47)\end{array}$ & $\begin{array}{c}0.39 \\
(0.32)\end{array}$ & $\begin{array}{c}0.66^{* * *} \\
(0.22)\end{array}$ \\
\hline Observations & & & - & 7,536 & 15,363 & 32,089 \\
\hline $\begin{array}{l}\text { Test of Equality in TE } \\
\text { (p-value) }\end{array}$ & & & 0.038 & 0.101 & 0.126 & 0.013 \\
\hline Bandwidth & & & IKBW & $0.05 \%$ & $0.1 \%$ & $0.2 \%$ \\
\hline
\end{tabular}

All notes to Table 1.9 apply.

position within four years. Table 1.13 provides the results obtained from estimating that incumbency effect for the subsamples of electoral units (municipalities) in which the corresponding elections presented candidates-per-seat ratios below and above the median in the corresponding year. Those estimates suggest that the effect of being elected on running for another position is larger for candidates winning in municipalities with a high level of competition. This scenario may reflect the possibility that candidates who win very competitive races are more likely to run for another (superior) position, since their chances of success are probably higher than those presented by candidates who win less

Table 1.13: City Councilor - Incumbency Effects by Electoral Competition

\begin{tabular}{|c|c|c|c|c|c|c|}
\hline & $\begin{array}{l}\text { Loser } \\
\text { Mean }\end{array}$ & $\begin{array}{c}\text { IKBW } \\
\{\text { obs }\}\end{array}$ & (1) & $(2)$ & $(3)$ & $(4)$ \\
\hline \multicolumn{7}{|c|}{ Panel A: Electoral Units with Below-Median Candidates per Seat } \\
\hline $\begin{array}{l}\text { Candidacy for another } \\
\text { pos. w/in } 4 \text { years }(\%) \\
\text { Observations }\end{array}$ & 2.22 & $\begin{array}{c}0.400 \\
\{24,260\}\end{array}$ & $\begin{array}{c}1.15^{* *} \\
(0.45) \\
-\end{array}$ & $\begin{array}{l}3.76^{*} \\
(2.05) \\
2,187\end{array}$ & $\begin{array}{l}2.09^{*} \\
(1.08) \\
5,299\end{array}$ & $\begin{array}{l}1.11 \\
(0.68) \\
11,614\end{array}$ \\
\hline \multicolumn{7}{|c|}{ Panel B: Electoral Units with Above-Median Candidates per Seat } \\
\hline $\begin{array}{l}\text { Candidacy for another } \\
\text { pos. w/in } 4 \text { years (\%) } \\
\text { Observations }\end{array}$ & 6.27 & $\begin{array}{c}0.400 \\
\{71,794\}\end{array}$ & $\begin{array}{c}4.09 * * * \\
(0.69) \\
-\end{array}$ & $\begin{array}{c}6.47^{* * *} \\
(1.50) \\
7,551\end{array}$ & $\begin{array}{c}5.18^{* * *} \\
(1.01) \\
15,650\end{array}$ & $\begin{array}{c}4.62^{* * *} \\
(0.73) \\
32,932\end{array}$ \\
\hline Test of Equality in TE (p-value) & & & 0.000 & 0.286 & 0.037 & 0.000 \\
\hline Bandwidth & & & IKBW & $0.05 \%$ & $0.1 \%$ & $0.2 \%$ \\
\hline
\end{tabular}

All notes to Table 1.9 apply. 
competitive elections. The null hypothesis of equality in that treatment effect for these two groups of candidates is once again rejected in three specifications at the $5 \%$ level. On the other hand, we do not find statistically significant evidence of heterogeneity of the effect on winning another position according to the level of electoral competition (the corresponding results are, therefore, omitted).

\subsubsection{Mayor}

In relation to the effects of incumbency as a first-term mayor, the results displayed in Table 1.14 suggest that being elected for that position incurs both a lower probability of running again and a lower chance of holding office after four years. According to the optimal bandwidth specification, barely winners are less likely than barely losers to run again and to win within four years by 10.91 p.p. and 20.72 p.p., respectively; however, estimates for the impact on running again are largely insignificant in other specifications.

Table 1.14: First-Term Mayor - Incumbency Effects on Candidacy/Victory

\begin{tabular}{|c|c|c|c|c|c|c|}
\hline & $\begin{array}{l}\text { Loser } \\
\text { Mean }\end{array}$ & $\begin{array}{c}\text { IKBW } \\
\{\text { obs }\}\end{array}$ & (1) & $(2)$ & $(3)$ & $(4)$ \\
\hline \multicolumn{7}{|l|}{ Panel $A$} \\
\hline Candidacy w/in 4 years (\%) & 78.42 & $\begin{array}{c}1.747 \\
\{1,384\}\end{array}$ & $\begin{array}{c}-10.91^{* *} \\
(4.80)\end{array}$ & $\begin{array}{l}-8.27 \\
(6.65)\end{array}$ & $\begin{array}{l}-4.07 \\
(2.84)\end{array}$ & $\begin{array}{l}-1.01 \\
(2.03)\end{array}$ \\
\hline Winning w/in 4 years (\%) & 54.4 & $\begin{array}{c}1.437 \\
\{1,165\}\end{array}$ & $\begin{array}{c}-20.72^{* * *} \\
(6.61)\end{array}$ & $\begin{array}{c}-21.87^{* * * *} \\
(8.01)\end{array}$ & $\begin{array}{c}-12.39 * * * \\
(3.47)\end{array}$ & $\begin{array}{c}-9.09^{* * *} \\
(2.46)\end{array}$ \\
\hline \multicolumn{7}{|l|}{ Panel B } \\
\hline $\begin{array}{l}\text { Candidacy for the same } \\
\text { pos. w/in } 4 \text { years }(\%)\end{array}$ & 64.38 & $\begin{array}{c}1.777 \\
\{1,410\}\end{array}$ & $\begin{array}{c}1.94 \\
(5.30)\end{array}$ & $\begin{array}{l}3.75 \\
(7.41)\end{array}$ & $\begin{array}{c}8.51^{* * *} \\
(3.11)\end{array}$ & $\begin{array}{c}13.25^{* * *} \\
(2.18)\end{array}$ \\
\hline $\begin{array}{l}\text { Winning the same } \\
\text { pos. w/in } 4 \text { years }(\%)\end{array}$ & 45.55 & $\begin{array}{c}1.361 \\
\{1,108\}\end{array}$ & $\begin{array}{r}-11.19 \\
(6.95)\end{array}$ & $\begin{array}{r}-12.32 \\
(8.24)\end{array}$ & $\begin{array}{l}-3.60 \\
(3.44)\end{array}$ & $\begin{array}{l}-0.15 \\
(2.42)\end{array}$ \\
\hline $\begin{array}{l}\text { Candidacy for another } \\
\text { pos. w/in } 4 \text { years }(\%)\end{array}$ & 15.42 & $\begin{array}{c}1.641 \\
\{1,308\}\end{array}$ & $\begin{array}{c}-14.45^{* * *} \\
(3.00)\end{array}$ & $\begin{array}{c}-14.21^{* * *} \\
(4.04)\end{array}$ & $\begin{array}{c}-15.45^{* * *} \\
(1.72)\end{array}$ & $\begin{array}{c}-17.12^{* * *} \\
(1.24)\end{array}$ \\
\hline $\begin{array}{l}\text { Winning another } \\
\text { pos. w/in } 4 \text { years }(\%)\end{array}$ & 9.94 & $\begin{array}{c}1.455 \\
\{1,180\}\end{array}$ & $\begin{array}{c}-9.90 * * * \\
(2.41)\end{array}$ & $\begin{array}{c}-10.07^{* * *} \\
(3.00)\end{array}$ & $\begin{array}{c}-8.99 * * * \\
(1.31)\end{array}$ & $\begin{array}{c}-9.31^{* * *} \\
(0.92)\end{array}$ \\
\hline Bandwidth & & & IKBW & $1 \%$ & $5 \%$ & $10 \%$ \\
\hline Observations & & & - & 838 & 4,293 & 8,013 \\
\hline
\end{tabular}

All notes to Table 1.10 apply.

As in the case of candidates for city councils, being elected as a mayor is associated with a lower chance of winning the same position after four years (although the corresponding estimates are statistically insignificant) despite also leading to a higher propensity to run again for the same position (although only larger bandwidths lead to significant estimates). On the other hand, in this case both the effect on running again for another 
position and the effect on winning another position are also negative and statistically significant. Hence, incumbency as a mayor in a first term appears to promote attempts to run for a second consecutive term as a mayor at the same time that it prevents candidates from running for (and being elected to) another position within four years. Barely winners are around 14-17 p.p. less likely to run for another position and around 9-10 p.p. less likely to win another position relative to barely losers. Table 1.C8 in the appendices provides evidence indicating that these negative effects are common to the propensities to run for and to win the positions of city councilor, state deputy, and federal deputy considered separately (in the last, however, the corresponding estimates are usually statistically insignificant). Such negative effects may occur partly by virtue of the requirement that mayors step down in order to run again, which could turn migration to other offices into an especially risky option for incumbent mayors, particularly if considered at midterm. In that case, mayors not only risk losing two years in office, but also compromising their reputations with the electorate for not fulfilling their mandates. On the other hand, stepping down to run for city council is less likely to involve the same issues since, in doing so, mayors would only need to stand down close to the end of the mayoral term. Thus, the finding of a negative effect on running for (and winning) the position of city councilor indicates that this position tends to be even less valued (relative to the position of mayor) by incumbents than by losers.

Table 1.15: First-Term Mayor - Incumbency Effects by Recent Political Experience

\begin{tabular}{llllll}
\hline Loser & IKBW & & & & \\
Mean & fobs $\}$ & $(1)$ & $(2)$ & $(3)$ & $(4)$ \\
\hline
\end{tabular}

Panel A: Candidates without Recent Experience

Winning the same

pos. w/in 4 years $(\%)$

Observations

$\begin{array}{ccc}46.19 & 1.466 & -14.52^{* *} \\ & \{967\} & (7.13)\end{array}$

$-$

$\begin{array}{ccc}-13.08 & -6.63 * & -2.51 \\ (8.73) & (3.70) & (2.61) \\ 679 & 3.484 & 6.534\end{array}$

$\begin{array}{lll}(8.73) & (3.70) \quad(2.61)\end{array}$

$679 \quad 3,484 \quad 6,534$

Panel B: Candidates with Recent Experience

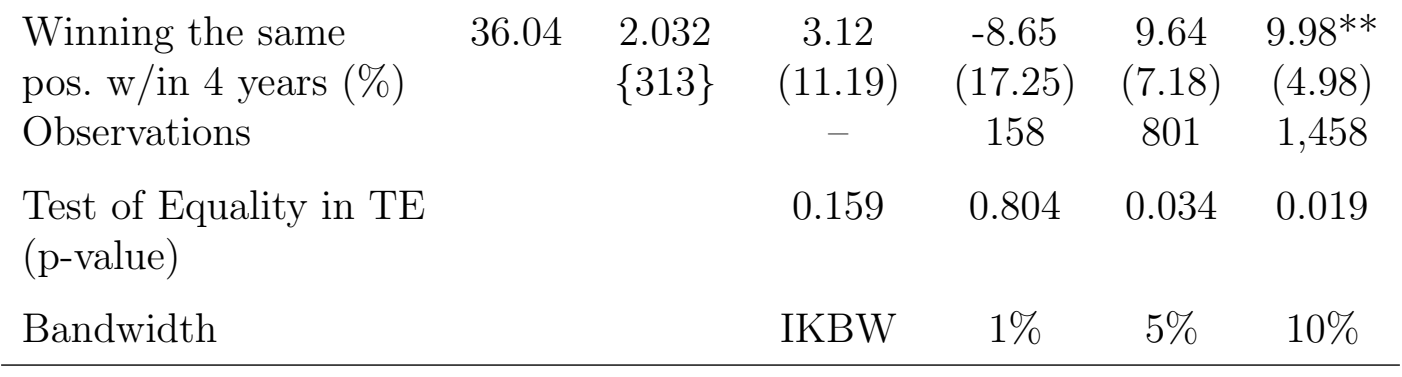

All notes to Table 1.10 apply.

In addition, Table 1.15 provides some evidence that the negative impact of incumbency as a first-term mayor on winning the same position in the next election is once again restricted to candidates without recent political experience (analogously to the results 
found for city councilors). Estimates obtained under the subsample of inexperienced candidates (Panel A) are always negative, whereas those for candidates with recent political experience tend to be positive (albeit largely statistically insignificant). In the present case, however, the null hypothesis of equality in the treatment effects for these two groups of candidates is rejected in only two specifications (those associated with the largest bandwidths). ${ }^{42}$

Lastly, we evaluate if being elected as a mayor may have distinct impacts on future candidacies and on political careers according to whether the corresponding victory leads the winning candidate to a first or a second (consecutive) mayoral term. In light of the above-mentioned fact that reelected mayors may not run for a third consecutive mayoral term, it is reasonable to expect that their following career decisions be different from those made by elected candidates who were not already incumbent mayors. Table 1.16 shows the effects on winning another position within four years, estimated alternately under the subsamples of candidates running for a first (non-consecutive) term (Panel A), and for a second (consecutive) term (Panel B); in particular, Panel A of that table replicates the results on winning another position presented in Table 1.14. We observe that while

Table 1.16: Mayor - Incumbency Effects by Term

\begin{tabular}{ccccccc}
\hline Loser & IKBW & & & & \\
Mean & \{obs $\}$ & $(1)$ & $(2)$ & $(3)$ & $(4)$ \\
\hline
\end{tabular}

Panel A: Candidates Running for a 1st Term

$\begin{array}{lcccccc}\text { Winning another } & 9.94 & 1.455 & -9.90^{* * *} & -10.07^{* * *} & -8.99^{* * *} & -9.31^{* * *} \\ \text { pos. w/in 4 years }(\%) & & \{1,180\} & (2.41) & (3.00) & (1.31) & (0.92) \\ \text { Observations } & & & - & 838 & 4,293 & 8,013\end{array}$

Panel B: Candidates Running for a 2nd Term

\begin{tabular}{|c|c|c|c|c|c|}
\hline $\begin{array}{l}\text { Winning another } \\
\text { pos. w/in } 4 \text { years }(\%)\end{array}$ & $\begin{array}{l}1.386 \\
\{317\}\end{array}$ & $\begin{array}{c}2.43 \\
(3.97)\end{array}$ & $\begin{array}{c}0.34 \\
(4.32)\end{array}$ & $\begin{array}{l}-1.68 \\
(2.10)\end{array}$ & $\begin{array}{l}-1.45 \\
(1.41)\end{array}$ \\
\hline Observations & & - & 235 & 1,173 & 2,247 \\
\hline $\begin{array}{l}\text { Test of Equality in TE } \\
\text { (p-value) }\end{array}$ & & 0.008 & 0.046 & 0.003 & 0.000 \\
\hline Bandwidth & & IKBW & $1 \%$ & $5 \%$ & $10 \%$ \\
\hline
\end{tabular}

All notes to Table 1.10 apply.

\footnotetext{
${ }^{42}$ Regarding incumbency as a first-term mayor, we have also found evidence of heterogeneity in the effects on running for and/or on winning another position according to candidates' recent political experience and to electorate sizes. However, for each of these dimensions, the associated instances of heterogeneity appear to be actually driven by a corresponding heterogeneity in the propensities to run for and to win another position across the losing candidates (i.e. in the loser means) of the related subsamples, whereas elected candidates in any subsample always show almost null propensities to run for and to win another position. For this reason, the corresponding results are omitted but are available from the author upon request.
} 
the incumbency effect on winning another position is negative and statistically significant for candidates who are not already holding office as mayors, the corresponding effect (of being reelected) for incumbent mayors has no clear sign and is statistically insignificant in all four specifications. In other words, candidates who run for a first term as mayor and win are less likely than their losing counterparts to win another position within four years, whereas incumbent mayors who are reelected for a second term show the same propensity to win another position relative to incumbent mayors who run for a second (consecutive) mayoral term and lose. At the $5 \%$ level, the null hypothesis of heterogeneity in the treatment effects for these two groups of candidates is rejected in all specifications.

\subsubsection{State Deputy}

Next, we consider the effects of incumbency as a state deputy. As shown in Panel A of Table 1.17, being elected to that position seems to have a small positive effect on the probability of running again within four years. Under the optimal bandwidth specification, we find statistically significant evidence that narrow winners are 5 p.p. more likely than narrow losers to run again (for any position). On the other hand, this effect does not translate into a relevant impact on the probability of winning again within four years, as the corresponding estimates have very low magnitudes, are always statistically insignif-

Table 1.17: State Deputy - Incumbency Effects on Candidacy/Victory

\begin{tabular}{|c|c|c|c|c|c|c|}
\hline & $\begin{array}{l}\text { Loser } \\
\text { Mean }\end{array}$ & $\begin{array}{c}\text { IKBW } \\
\{\text { obs }\}\end{array}$ & $(1)$ & $(2)$ & $(3)$ & $(4)$ \\
\hline \multicolumn{7}{|l|}{ Panel $A$} \\
\hline Candidacy $\mathrm{w} /$ in 4 years $(\%)$ & 88.10 & $\begin{array}{c}0.189 \\
\{6,152\}\end{array}$ & $\begin{array}{c}5.70^{* * *} \\
(1.99)\end{array}$ & $\begin{array}{c}2.23 \\
(3.18)\end{array}$ & $\begin{array}{l}3.92^{*} \\
(2.02)\end{array}$ & $\begin{array}{l}5.32^{* *} \\
(1.97)\end{array}$ \\
\hline Winning w/in 4 years $(\%)$ & 44.75 & $\begin{array}{c}0.152 \\
\{4,528\}\end{array}$ & $\begin{array}{l}-0.11 \\
(3.77)\end{array}$ & $\begin{array}{l}-1.81 \\
(5.28)\end{array}$ & $\begin{array}{l}-3.73 \\
(2.77)\end{array}$ & $\begin{array}{c}3.11 \\
(3.38)\end{array}$ \\
\hline \multicolumn{7}{|l|}{ Panel B } \\
\hline $\begin{array}{l}\text { Candidacy for the same } \\
\text { pos. w/in } 4 \text { years }(\%)\end{array}$ & 67.89 & $\begin{array}{c}0.106 \\
\{2,913\}\end{array}$ & $\begin{array}{c}11.52^{* * *} \\
(3.16)\end{array}$ & $\begin{array}{c}2.66 \\
(4.75)\end{array}$ & $\begin{array}{c}10.87^{* * *} \\
(3.40)\end{array}$ & $\begin{array}{c}21.52^{* * *} \\
(5.15)\end{array}$ \\
\hline $\begin{array}{l}\text { Winning the same } \\
\text { pos. w/in } 4 \text { years }(\%)\end{array}$ & 27.38 & $\begin{array}{c}0.124 \\
\{3,515\}\end{array}$ & $\begin{array}{c}13.17^{* * *} \\
(3.83)\end{array}$ & $\begin{array}{c}9.68^{* * *} \\
(3.13)\end{array}$ & $\begin{array}{c}8.65^{* *} \\
(3.21)\end{array}$ & $\begin{array}{c}20.10^{* * *} \\
(4.78)\end{array}$ \\
\hline $\begin{array}{l}\text { Candidacy for another } \\
\text { pos. w/in } 4 \text { years }(\%)\end{array}$ & 52.92 & $\begin{array}{c}0.291 \\
\{11,869\}\end{array}$ & $\begin{array}{c}-27.83^{* * *} \\
(4.56)\end{array}$ & $\begin{array}{c}-9.50 * * \\
(3.76)\end{array}$ & $\begin{array}{c}-17.12^{* * *} \\
(3.39)\end{array}$ & $\begin{array}{c}-23.71^{* * *} \\
(4.99)\end{array}$ \\
\hline $\begin{array}{l}\text { Winning another } \\
\text { pos. w/in } 4 \text { years }(\%)\end{array}$ & 26.71 & $\begin{array}{c}0.259 \\
\{10,088\}\end{array}$ & $\begin{array}{c}-20.16^{* * *} \\
(1.89)\end{array}$ & $\begin{array}{c}-12.43^{* *} \\
(5.52)\end{array}$ & $\begin{array}{c}-14.38^{* * *} \\
(3.72)\end{array}$ & $\begin{array}{c}-19.27^{* * * *} \\
(3.04)\end{array}$ \\
\hline Bandwidth & & & IKBW & $0.05 \%$ & $0.1 \%$ & $0.2 \%$ \\
\hline Observations & & & - & 1,357 & 2,763 & 6,665 \\
\hline
\end{tabular}

All notes to Table 1.9 apply. 
Table 1.18: State Deputy - Incumbency Effects by Electoral Competition

\begin{tabular}{|c|c|c|c|c|c|c|}
\hline & $\begin{array}{l}\text { Loser } \\
\text { Mean }\end{array}$ & $\begin{array}{l}\text { IKBW } \\
\{\text { obs }\}\end{array}$ & $(1)$ & (2) & $(3)$ & $(4)$ \\
\hline \multicolumn{7}{|c|}{ Panel A: Electoral Units with Below-Median Candidates per Seat } \\
\hline $\begin{array}{l}\text { Candidacy for another } \\
\text { pos. w/in } 4 \text { years }(\%)\end{array}$ & 35.19 & $\begin{array}{c}0.207 \\
\{2,159\}\end{array}$ & $\begin{array}{c}-11.55^{* * *} \\
(3.66)\end{array}$ & $\begin{array}{l}-3.38 \\
(9.11)\end{array}$ & $\begin{array}{l}-8.68 \\
(6.21)\end{array}$ & $\begin{array}{c}-10.26^{* *} \\
(3.59)\end{array}$ \\
\hline Observations & & & - & 527 & 1,020 & 2,065 \\
\hline \multicolumn{7}{|c|}{ Panel B: Electoral Units with Above-Median Candidates per Seat } \\
\hline $\begin{array}{l}\text { Candidacy for another } \\
\text { pos. w/in } 4 \text { years }(\%)\end{array}$ & 54.29 & $\begin{array}{c}0.207 \\
\{4,851\}\end{array}$ & $\begin{array}{c}-30.61^{* * *} \\
(4.50)\end{array}$ & $\begin{array}{c}-14.77^{* * *} \\
(3.06)\end{array}$ & $\begin{array}{c}-22.73^{* * *} \\
(3.01)\end{array}$ & $\begin{array}{c}-30.77^{* * *} \\
(4.71)\end{array}$ \\
\hline Observations & & & - & 830 & 1,743 & 4,600 \\
\hline Test of Equality in TE (p-value) & & & 0.001 & 0.249 & 0.045 & 0.001 \\
\hline Bandwidth & & & IKBW & $0.05 \%$ & $0.1 \%$ & $0.2 \%$ \\
\hline
\end{tabular}

All notes to Table 1.9 apply.

icant and do not present a clear sign. In other words, the probability that candidates (narrowly) elected as state deputies will be holding some office after four years is the same as that presented by candidates who ran for that position and narrowly lost. As made explicit in Panel $\mathrm{B}$ of the same table, this finding arises from the fact that while incumbency as a state deputy is associated with significantly higher propensities to run for and to win that same position after four years, it is also linked to significant negative impacts on running for and on winning another position in that time frame. The point estimates obtained by employing the IKBW indicate that, relative to narrow losers, narrow winners are more likely to run for and to win the position of state deputy by 11.5 p.p. and 13 p.p. respectively, and less likely to run for and to win another position by 28 p.p. and 20 p.p. respectively. These two sets of opposite effects happen to cancel out, and lead to aggregate effects on running and winning that are close to zero.

However, we also find that such negative effects on the probabilities of running for and of winning another position do not apply for all positions. Table 1.C9 in the appendices reveals that, although incumbency as a state deputy is associated with statistically significant negative impacts on the likelihood of running for and of winning the positions of either city councilor or mayor, barely elected state deputies are more likely than barely losers to run for and to win the position of federal deputy after four years (though the estimates corresponding to the latter outcomes are statistically significant in only a few specifications). In particular, we find under the optimal bandwidth specification that barely winners are 1.47 p.p. more likely than barely losers to be elected as federal deputies in four years, actually a sizeable effect given that only $0.67 \%$ of barely losers manage to win that position in four years. 
Furthermore, our results suggest that the relevance of the incumbency status in affecting the probability of running for another position depends on the degree of electoral competition in the corresponding state deputy election. As displayed in Table 1.18 , that effect of incumbency is negative for both competition-based groups of candidates, but the reduction in the probability of running for another position attributed to incumbency is more pronounced for candidates that run (at time $t$ ) in elections with relatively high levels of competition. Under the optimal bandwidth specification, we find that in less competitive elections barely winners are 11.5 p.p. less likely than barely losers to run for another position within four years, whereas barely winners of elections with a relatively high degree of competition are 31 p.p. less likely than their losing counterparts to run for another position in that time frame. The null hypothesis of equality in the treatment effects is rejected at the $5 \%$ level in three specifications. In light of the fact that the average propensity to run for another position displayed by winning candidates of both groups is similar (and close to 24\%), such heterogeneity may be attributed to differences in the corresponding probabilities among losing candidates of each group. Such a difference, in turn, could be because higher levels of competition in the election for state assembly lead to less optimistic prospects for losers concerning a future victory in that same position, so these losing candidates are less motivated to run again for the same position and may opt to try running for another position instead.

\subsubsection{Federal Deputy}

Lastly, we discuss the results concerning the effects of incumbency as a federal deputy. We observe from the estimates presented in Table 1.19 that being elected to that position is associated with a fairly significant positive impact on the probability of winning an election within four years, which happens despite the fact that the effect on the propensity to run again is much smaller in magnitude and usually statistically insignificant. As in the case of state deputies, these composite effects combine positive impacts on the chances to run for and to win the same position, with negative effects on the probabilities of running for and of winning another position within four years; in the present case, however, the negative impact on the probability of winning another position is not high enough to completely counterbalance the positive effect on winning the same position, so barely winners tend to exhibit higher chances of (still) being in charge of some elective office after four years than barely losers.

The point estimates associated with the IKBW specification indicate that barely winners are more likely than barely losers to run for, and to win, the same position by 14 p.p. and 29 p.p., respectively. In particular, the latter figure represents the largest estimated 
Table 1.19: Federal Deputy - Incumbency Effects on Candidacy/Victory

\begin{tabular}{|c|c|c|c|c|c|c|}
\hline & $\begin{array}{l}\text { Loser } \\
\text { Mean }\end{array}$ & $\begin{array}{c}\text { IKBW } \\
\{\text { obs }\}\end{array}$ & (1) & $(2)$ & $(3)$ & (4) \\
\hline \multicolumn{7}{|l|}{ Panel $A$} \\
\hline Candidacy w/in 4 years (\%) & 87.80 & $\begin{array}{c}0.231 \\
\{1,595\}\end{array}$ & $\begin{array}{c}5.21 \\
(4.00)\end{array}$ & $\begin{array}{c}2.83 \\
(4.87)\end{array}$ & $\begin{array}{l}5.79^{*} \\
(3.00)\end{array}$ & $\begin{array}{l}1.91 \\
(4.86)\end{array}$ \\
\hline Winning w/in 4 years (\%) & 37.18 & $\begin{array}{c}0.248 \\
\{1,749\}\end{array}$ & $\begin{array}{c}16.45^{* *} \\
(6.18)\end{array}$ & $\begin{array}{c}4.44 \\
(11.51)\end{array}$ & $\begin{array}{c}15.45^{*} \\
(8.08)\end{array}$ & $\begin{array}{l}14.80^{*} \\
(7.95)\end{array}$ \\
\hline \multicolumn{7}{|l|}{ Panel B } \\
\hline $\begin{array}{l}\text { Candidacy for the same } \\
\text { pos. w/in } 4 \text { years }(\%)\end{array}$ & 65.09 & $\begin{array}{c}0.194 \\
\{1,283\}\end{array}$ & $\begin{array}{c}13.91^{* *} \\
(6.19)\end{array}$ & $\begin{array}{c}3.41 \\
(5.79)\end{array}$ & $\begin{array}{l}7.11 \\
(6.54)\end{array}$ & $\begin{array}{c}13.64^{* *} \\
(5.93)\end{array}$ \\
\hline $\begin{array}{l}\text { Winning the same } \\
\text { pos. w/in } 4 \text { years }(\%)\end{array}$ & 17.19 & $\begin{array}{c}0.262 \\
\{1,890\}\end{array}$ & $\begin{array}{c}29.19^{* * *} \\
(4.09)\end{array}$ & $\begin{array}{c}15.66 \\
(10.10)\end{array}$ & $\begin{array}{l}19.55^{* * *} \\
(6.36)\end{array}$ & $\begin{array}{c}26.00^{* * *} \\
(5.53)\end{array}$ \\
\hline $\begin{array}{l}\text { Candidacy for another } \\
\text { pos. w/in } 4 \text { years }(\%)\end{array}$ & 52.46 & $\begin{array}{c}0.400 \\
\{3,275\}\end{array}$ & $\begin{array}{c}-29.55^{* * *} \\
(4.46)\end{array}$ & $\begin{array}{c}-19.44^{* *} \\
(6.99)\end{array}$ & $\begin{array}{c}-18.68^{* * *} \\
(6.08)\end{array}$ & $\begin{array}{c}-23.97^{* * *} \\
(6.64)\end{array}$ \\
\hline $\begin{array}{l}\text { Winning another } \\
\text { pos. w/in } 4 \text { years }(\%)\end{array}$ & 19.68 & $\begin{array}{c}0.360 \\
\{2,857\}\end{array}$ & $\begin{array}{c}-13.79^{* * *} \\
(2.19)\end{array}$ & $\begin{array}{c}-12.03^{* *} \\
(4.59)\end{array}$ & $\begin{array}{l}-5.57 \\
(5.31)\end{array}$ & $\begin{array}{c}-12.31^{* *} \\
(4.84)\end{array}$ \\
\hline Bandwidth & & & IKBW & $0.05 \%$ & $0.1 \%$ & $0.2 \%$ \\
\hline Observations & & & - & 284 & 555 & 1,341 \\
\hline
\end{tabular}

All notes to Table 1.9 apply.

effect of incumbency on the probability of winning the same position across all of the four positions considered in our analysis, and corresponds to a $170 \%$ increase in that probability. Also, we find that, relative to barely losers, barely winners are almost 30 p.p. less likely to run for another position, and 14 p.p. less likely to win elections for another position in that time frame.

Moreover, Table 1.C10 in the appendices shows that the negative effect found in the probabilities to run for and to win another position also apply when we separately consider the impacts on candidacy and on victory in each of the other three main positions, although the estimates related to some of these outcomes are usually statistically insignificant. Also, unlike the preceding cases, we do not find robust statistically significant evidence of heterogeneity in the effects of incumbency as a federal deputy according to any of the political and demographic dimensions previously explored, which may be due to the relatively low number of observations on candidates for that position. ${ }^{43}$

\footnotetext{
${ }^{43}$ Regarding the incumbency effect on winning the same position after four years, for instance, we find that candidates with recent political experience are associated with point estimates with larger magnitudes relative to the corresponding estimates obtained for inexperienced candidates. However, the null hypothesis of equality in the treatment effects for these two groups of candidates is not rejected in any specification at the $5 \%$ level, and is only rejected in two specifications at the $10 \%$ level.
} 


\subsection{Bounds on Effects on Winning Conditional on Candidacy}

The preceding estimation of the diverse significant effects of holding office on winning subsequent elections raises the question of whether these impacts simply and solely reflect the circumstance that incumbents are more (or less) likely to run in them or, rather, if incumbency status does indeed lead to an electoral advantage (or disadvantage) even among those candidates who run again. While the consideration of incumbency effects on subsequent candidacies in the last section may provide some intuition on the matter, it does not allow us to infer the magnitudes of the effects on winning conditional on candidacy, even when the effects on running are insignificant.

This is due to the fact that even if narrow winners and narrow losers are, on average, similar, the same is much less likely to be true once only those who run again are considered, since the decision to file a new candidacy is probably dependent upon the candidate's future electoral prospects (being, therefore, endogenous). In other words, the issue of (non-random) selection into running again possibly makes treated and control individuals systematically different conditional on filing a new candidacy, even if the preceding treatment were randomly assigned. Thus, conditioning the estimation of incumbency effects on winning to candidates who run again would lead to biased results even under a regression discontinuity setup. ${ }^{44}$ For this reason, attempts at estimating these conditional effects (with a causal interpretation) would usually require addressing the issue of nonrandom sample selection by imposing exclusion restrictions on determinants of candidacy and winning probabilities.

Alternatively, we employ a method devised by Anagol and Fujiwara (2015) and Lee (2009) to obtain bounds on incumbency effects on the chance of winning a given subsequent election, conditional on running in it. The definitions and notation below follow closely those of Anagol and Fujiwara (2015). Let $I$ denote if a candidate won an elective position at time $t$, and let $R_{0}$ and $R_{1}$ be binary indicators on whether the candidate runs in a given subsequent election when $I=0$ or $I=1$, respectively. That is, $R_{0}$ and $R_{1}$ are potential outcome indicators in the sense that, for instance, $R_{1}$ reflects the candidate's decision to run again had he/she won at $t$ irrespective of whether he/she actually won. Naturally, only one of these outcomes is observed for each individual; denoting the observed outcome by $R$, we have that $R=I R_{1}+(1-I) R_{0}$. Likewise, let $W_{0}$ and $W_{1}$ be binary indicators on whether the candidate would win the given subsequent election, had he/she chosen to run in it, when $I=0$ or $I=1$, respectively. Then only $W \equiv R\left[I W_{1}+(1-I) W_{0}\right]$ is observed for each candidate; in particular, if a candidate does not run $(R=0)$, then

\footnotetext{
${ }^{44}$ See, for instance, Heckman $\sqrt{1979)}$ and Angrist and Pischke $(2008)$.
} 
he/she does not win $(W=0)$. That is, $W$ corresponds to the unconditional measure of victory explored in the last section.

Consider a sample of candidates who run for position $p_{0}$ at $t$, and let $p_{1}$ denote a position up for election at some point in $[t+1, t+4]$. Candidates in that sample may then be divided into the following mutually exclusive and collectively exhaustive groups: $(i)$ "always-takers," those who run for $p_{1}$ within four years regardless of their incumbency status following election at $t,(i i)$ "compliers," those who choose to run for $p_{1}$ within four years only upon being elected at $t$, (iii) "never-takers," those who do not run for $p_{1}$ within four years, and (iv) "defiers," those who would run for $p_{1}$ within four years if non-elected at $t$, but not if elected.

Following Lee (2009), the required assumptions for computing bounds of the desired conditional causal effects in our context are that $\left(W_{0}, W_{1}, R_{0}, R_{1}\right)$ is independent of $I$ (conditional on barely losing/winning), and that there are no defiers, so incumbency assignment can only affect sample selection in one direction. ${ }^{45}$ The latter assumption implies that all candidates who are elected for $p_{0}$ at $t$ and who choose not to run for $p_{1}$ within four years would also make that choice had they not been elected; also, all candidates who (run and) are not elected for $p_{0}$ at $t$ and who choose to run for $p_{1}$ within four years would also run had they been elected (at $t$ ). In our context, however, this assumption is not likely to be reasonable for all possible pairs of positions $\left(p_{0}, p_{1}\right)$. Among candidates who run for mayor at $t$ and lose, for instance, there is likely to be a significant fraction of individuals who choose to run for city councilor (or state deputy) within four years and who would not make that decision had they been elected. Thus, we consider this assumption to be valid in three scenarios: (a) whenever $p_{0}=p_{1}$, (b) if $p_{0}$ is the position of city councilor and $p_{1}$ is any other position, and (c) if $p_{0}$ and $p_{1}$ are the positions of state deputy and federal deputy, respectively.

Under the assumption of "no-defiers," we have the following equality: ${ }^{46}$

$$
\begin{aligned}
& \text { Effect on winning, cond. on being always-taker/complier } \\
& \overbrace{E\left(W_{1}-W_{0} \mid M=0, R_{1}=1\right)}^{=}= \\
& \underbrace{E\left(R_{1} \mid M=0\right)}_{\text {lim }_{M \downarrow 0} E(R \mid M)}[\underbrace{E\left(W_{1} R_{1}-W_{0} R_{0} \mid M=0\right)}_{\text {RD effect on } W}-\underbrace{\operatorname{Pr}\left(R_{1}>R_{0} \mid M=0\right)}_{\text {RD effect on } R} \cdot \underbrace{E\left(W_{0} \mid M=0, R_{1}>R_{0}\right)}_{\text {Unobservable }}]
\end{aligned}
$$

The term on the left represents an average effect of incumbency on the probability of

\footnotetext{
${ }^{45}$ Both the terminology used for defining the partitioning of the population into subgroups (alwaystakers, compliers, etc.) and the "no-defiers" assumption are commonly employed in studies related to imperfect compliance of treatment (Angrist et al. (1996)). The difference is that in those studies they refer to how an instrument affects treatment status, whereas here they allude to how treatment affects sample selection.

${ }^{46}$ For the corresponding derivations, the reader is referred to Anagol and Fujiwara $(2015)$.
} 
winning had the corresponding candidates chosen to run, and this is the sense in which we refer to that effect as one conditional on running; in particular, it should not be mistaken for an effect of incumbency obtained upon conditioning the sample to those candidates who actually ran again. Naturally, it is conditioned only to candidates who would eventually run again (always-takers and compliers), as such an effect would be meaningless when related to other candidates (never-takers). Notice also that the first three terms on the right were estimated in our previous regression discontinuity exercises. The only unobservable term is $E\left(W_{0} \mid M=0, R_{1}>R_{0}\right)$, which represents the probability of winning position $p_{1}$ within four years after (hypothetically) losing position $p_{0}$ at $t$ for a close winner or loser complier. Then, given certain assumptions on the smallest and largest values that this probability may take, we are able to estimate lower and upper bounds (along with corresponding standard errors) on the conditional effects of incumbency.

For a given conditional effect of incumbency (i.e. given $p_{0}$ and $p_{1}$ ), the upper bound is calculated by inputting $E\left(W_{0} \mid M=0, R_{1}>R_{0}\right)=0$ in equation 1.3 ; that is, by assuming that a close (winner or loser) complier would never win position $p_{1}$ had he/she run for $p_{0}$ at $t$ and lost. In that case, incumbency could only have a non-negative effect on winning for such a candidate. Similarly, a lower bound could be estimated by assuming that $E\left(W_{0} \mid M=0, R_{1}>R_{0}\right)=1$; however, we find that hypothesis to be unreasonably extreme. Rather, we assume that such probability is at most the same as that presented by candidates who barely lost election for $p_{0}$ at $t$ and who actually ran for $p_{1}$ within four years. In essence, this means that lower bounds are calculated by implicitly assuming that losing candidates who decide to run do so precisely because they have a greater conditional probability of winning (relative to candidates of a similar quality who do not run) ${ }^{47}$ All estimates of bounds on incumbency effects conditional on running presented here are based on the estimates obtained for each of the observed terms (as well as for the approximation on the unobserved term, in the case of lower bounds) under the optimal bandwidth specification; the corresponding standard errors are derived under the delta method.

Table 1.20 presents the results concerning the conditional effects of incumbency as a city councilor. We observe that the previously suggested hypothesis that being elected for that position incurs, on average, an electoral disadvantage is reinforced by the fact that even the upper bound on the conditional effect on winning is negative and statistically significant. That estimate suggests that, conditional on running again for the same posi-

\footnotetext{
${ }^{47}$ Anagol and Fujiwara $(2015)$ assume that $E\left(W_{0} \mid M=0, R_{1}>R_{0}\right)$ is at most the probability of winning of treated individuals who chose to run. We find this hypothesis to be inadequate in our context as the preceding results suggest that incumbency may be associated with a negative effect in some scenarios.
} 
tion, narrow winners are (at best) 5.37 p.p. less likely to win than narrow losers. However, despite the fact that the same qualitative conclusion applies to inexperienced candidates alone (associated with an even lower upper bound of -10.12 p.p.), we see that it is not valid for candidates with recent experience (Panels B1 and B2). As shown in Panel B2, the point estimate of the upper bound related to experienced candidates is positive and statistically insignificant; hence, we cannot assess the sign of the conditional effect on winning for that group. In any case, both lower and upper bound estimates present low magnitudes, so for that group of candidates incumbency is unlikely to have a relevant effect on winning conditional on running for the same position again. A similar situation occurs when we look at the bounds on the effect on winning conditional on running for another position, considering the whole sample of candidates for city council (Panel A). While the estimated upper bound is positive and statistically significant, we do not reject the null hypothesis that the lower bound is equal to zero.

Table 1.20: Incumbency Effects on Winning Conditional on Running - City Councilor

(1)

Lower Bound Upper Bound

Panel A: Baseline Results

Winning w/in 4 years (\%) |

Running for the same position

$-11.23^{* * *}$

$-5.37 * * *$

Winning w/in 4 years (\%) |

Running for another position

Panel B1: Candidates without Recent Experience

Winning w/in 4 years (\%) |

$-15.68^{* * *}$

$-10.12^{* * *}$

Running for the same position

Panel B2: Candidates with Recent Experience

Winning w/in 4 years (\%) |

Running for the same position

Lower and upper bounds are based on estimates of the terms in the right-hand side of equation 1.3 obtained under the optimal bandwidth specification. Standard errors (in parenthesis) are computed under the delta method. *, **, and *** indicate significance at the $10 \%, 5 \%$ and $1 \%$ levels, respectively.

In turn, estimates of bounds on the corresponding effects of incumbency as a mayor are provided in Table 1.21. As with our results regarding city councilors, we also find evidence that being elected as a mayor has a negative effect on winning that same position four years later, conditional on running for it. In this case, though, we do not reject the hypothesis that such effect is different from zero, since the associated upper bound is statistically insignificant (Panel A). However, by considering subgroups of mayoral 
Table 1.21: Incumbency Effects on Winning Conditional on Running - First-Term Mayor

(1)

Lower Bound Upper Bound

Panel A: Baseline Results

Winning w/in 4 years (\%) |

$-18.94^{* *} \quad-16.87$

Running for the same position

Panel B1: Candidates without Recent Experience

Winning w/in 4 years (\%) |

$-21.48^{* *}$

Running for the same position

Panel B2: Candidates with Recent Experience

Winning w/in 4 years (\%) |

Running for the same position

Panel C1: Electoral Units with Below-Median Electorate

Winning w/in 4 years (\%) |

$-21.59^{* *}$

Running for the same position

Panel C2: Electoral Units with Above-Median Electorate

Winning w/in 4 years (\%) |

Running for the same position

$(10.76)$

See notes to Table 1.20 .

candidates according to recent political experience (Panels B1 and B2), we find that both lower and upper bounds on that effect for inexperienced candidates are statistically significant (at the $10 \%$ level) and very close in magnitude, suggesting that (inexperienced) barely winners are around 21 p.p. less likely than (inexperienced) barely losers to win the same position four years later, conditional on running for it. On the other hand, both bounds on the effect for candidates with recent experience are positive, but statistically insignificant. Similarly, when alternately considering subgroups of candidates according to the electorate size of the municipality (Panels C1 and C2), our estimates suggest that candidates who run in relatively small municipalities are subject to a negative incumbency effect (bounded between -27 p.p. and -22 p.p.) on winning conditional on running again for the same position. Both estimated bounds corresponding to candidates in relatively large municipalities are also negative, but much lower in magnitude and statistically insignificant. In particular, such difference in the results for these two groups of candidates is consistent with the idea that elected officials in small constituencies are subject to a more intense pressure and scrutiny from the electorate relative to those elected in large constituencies (Seabright (1996)). 
Lastly, Table 1.22 presents the results for the lower and upper bounds on the conditional effects of incumbency either as a state deputy or as a federal deputy. For each of these positions, our estimates indicate that the effect on winning conditional on running for the same position four years later is positive and statistically significant, as the same is true for both corresponding lower and upper bounds. Among state deputies, we find that barely winners are around 10-17 p.p. more likely than barely losers to win the same position conditional on running for it. As for federal deputies, the point estimates indicate that barely winners are at least 32 p.p. more likely than barely losers to win that same position four years later conditional on running again, a very significant effect. Contrary to the recent empirical research on the electoral effects of incumbency in Brazil (more generally, in developing countries), these results provide novel evidence on an incumbency advantage rather than a disadvantage. Moreover, we find evidence that incumbency as a state deputy is also associated with a sizeable positive impact on the probability of winning an election for the position of federal deputy conditional on running. Our results suggest that barely winners are around 22-23 p.p. more likely than barely losers to be elected as federal deputies four years later, conditional on running. This finding represents the most clear instance among all of our results that incumbency of a given position may generate an electoral advantage not only in winning the same position again, but also in winning elections for other (higher) offices.

Table 1.22: Incumbency Effects on Winning Conditional on Running - State and Federal Deputies

(1)

Lower Bound Upper Bound

Panel A: State Deputy

Winning w/in 4 years (\%) |

$10.37^{* *}$

Running for the same position

$16.58^{* * *}$

Winning w/in 4 years $(\%) \mid$

$22.39 * * *$

Running for federal deputy

$22.95^{* * *}$

Panel B: Federal Deputy

Winning w/in 4 years (\%) |

$31.90^{* * *}$

$36.96^{* * *}$

Running for the same position

$(5.24)$

See notes to Table 1.20 . 


\subsection{Other Incumbency Effects Conditional on Candidacy}

\subsubsection{Effects on Campaign Spending}

In this section, we make use of the same approach adopted in the last section to estimate bounds on the effect of incumbency on the amount of campaign spending in a given subsequent election. ${ }^{48}$ Since campaign expenditures are only defined for those who decide to run, we refrain from explicitly noting in the following discussion that our estimates correspond to an effect that is conditional on running. Aside from being of interest in its own right, such an effect may constitute a channel through which the previously explored impacts on winning occur, since an electoral advantage possibly enjoyed by incumbents may be the result of a greater ability to gather campaign funds and to use them in attracting the votes of impressionable voters. However, our results must be interpreted with some caution as data on campaign expenditures contain a fairly large proportion of missing values, and may also be subjected to a high level of misreporting by candidates.

Table 1.23 displays the results corresponding to the effect of being elected as a city councilor. First, we observe that incumbency is associated with a significant increase

Table 1.23: Effects on Campaign Spending - City Councilor

\begin{tabular}{lcc}
\hline & $(1)$ & $(2)$ \\
& Lower Bound & Upper Bound \\
\hline Panel A: Baseline Results & & \\
Campaign spending | & $1,885.64^{* * *}$ & $2,714.93^{* * *}$ \\
Running for the same position & $(515.66)$ & $(672.78)$ \\
& & \\
Campaign spending | & $1,839.45$ & $15,937.92^{* * *}$ \\
Running for another position & $(3,147.64)$ & $(2,923.27)$ \\
& & \\
Panel B1: Candidates without Recent Experience & & \\
Campaign spending | & $1,420.76^{* * *}$ & $2,280.47^{* * *}$ \\
Running for the same position & $(478.08)$ & $(575.96)$ \\
Panel B2: Candidates with Recent Experience & & \\
Campaign spending | & $3,646.98^{* * *}$ & $4,615.44^{* * *}$ \\
Running for the same position & $(984.51)$ & $(1,172.74)$ \\
\hline
\end{tabular}

See notes to Table 1.20 .

\footnotetext{
${ }^{48}$ The results in the present section have been replicated by considering the amount of funds raised rather than that spent by candidates in their political campaigns. As expected, both sets of results are qualitatively identical.
} 
in campaign expenditures when running again for that position. The lower and upper bounds are estimated to be around 1,900 and 2,700 reais, respectively, and both are statistically significant. ${ }^{49}$ Also, exactly the same conclusion is reached when we consider that effect for candidates either with or without recent political experience, though the estimated bounds associated with experienced candidates show more than twice the magnitude of the corresponding bounds related to inexperienced candidates. In particular, this finding enables us to rule out the suggestion that the electoral disadvantage from incumbency found for inexperienced candidates running for city council possibly stems from a lower level of campaign funds collected by incumbents relative to runners-up. On the other hand, we find no conclusive evidence of the incumbency effect on campaign spending when running for another position. While the corresponding upper bound is fairly large and statistically significant (pointing to an increase of almost 16 thousand reais in expenditures), the associated lower bound is much smaller in magnitude and statistically insignificant.

Table 1.24: Effects on Campaign Spending - First-Term Mayor

\begin{tabular}{lcc}
\hline & $\begin{array}{c}(1) \\
\text { Lower Bound }\end{array}$ & $\begin{array}{c}(2) \\
\text { Upper Bound }\end{array}$ \\
\hline Panel A: Baseline Results & & \\
Campaign spending | & $15,742.61^{*}$ & $17,177.54^{* *}$ \\
Running for the same position & $(8,090.33)$ & $(7,229.09)$ \\
& & \\
Panel B1: Candidates without Recent Experience & & \\
Campaign spending | & $10,303.36$ & $10,180.48^{*}$ \\
Running for the same position & $(6,597.66)$ & $(5,410.07)$ \\
Panel B2: Candidates with Recent Experience & & \\
Campaign spending | & $46,455.06$ & $47,717.88$ \\
Running for the same position & $(33,365.49)$ & $(32,300.99)$ \\
& & \\
Panel C1: Electoral Units with Below-Median Electorate & \\
Campaign spending | & $7,997.68^{* * *}$ & $6,722.24^{* * *}$ \\
Running for the same position & $(2,833.99)$ & $(2,057.07)$ \\
Panel C2: Electoral Units with Above-Median Electorate & \\
Campaign spending | & $20,880.82$ & $26,711.62^{* *}$ \\
Running for the same position & $(14,984.00)$ & $(12,933.45)$ \\
\hline
\end{tabular}

See notes to Table 1.20 .

In addition, the estimated bounds on the effect of incumbency as a first-term mayor on

\footnotetext{
${ }^{49}$ Campaign spending is measured in reais of 2000 , when 1.80 real was approximately equivalent to one U.S. dollar.
} 
campaign expenditures when running again for that position are presented in Table 1.24 . The point estimates in Panel A suggest that such incumbency increases expenditures by approximately 16-17 thousand reais, and both lower and upper bounds are statistically significant. By separately considering subsamples of candidates defined according to their political experience, we also note that the estimates associated with experienced candidates are a lot larger than those referring to inexperienced ones, but for both groups the lower bound estimate is statistically insignificant; thus, we cannot reject the hypothesis that incumbency has no effect on the level of campaign expenditures for candidates running again for the position of mayor. Analogous conclusions are drawn when we analyze the corresponding effect for candidates who contested mayoral elections at $t$ in municipalities with either relatively small or relatively large electorate sizes (Panels C1 and C2). Although the estimated bounds associated with candidates running in large municipalities are not statistically different from zero, we find that for candidates in small municipalities, both lower and upper bounds are statistically significant. Thus, we conclude that for this subset of candidates as well, the (previously found) negative incumbency effect on winning is not driven by lower levels of campaign expenditures resulting from holding office.

Next, we consider the effects on campaign expenditures from incumbency as a state deputy and as a federal deputy; Table 1.25 displays the corresponding results. Regarding incumbency as a state deputy, we find evidence of a positive and significant effect on the levels of campaign expenditures when running again for that position (and that increase is bounded between 39 thousand and 57 thousand reais, approximately), and also when running for the position of federal deputy, where the corresponding estimates point to an increase in expenditures by approximately 150 thousand reais, a much larger effect.

Table 1.25: Effects on Campaign Spending - State and Federal Deputies

Lower Bound Upper Bound

Panel A: State Deputy

Campaign spending | $39,600.74^{* * *} \quad 57,453.28^{* * *}$

Running for the same position

Campaign spending | $147,951.89^{* * *} \quad 152,030.50 * * *$

Running for federal deputy

Panel B: Federal Deputy

Campaign spending |

$92,172.04$

$143,206.33^{* *}$

Running for the same position

$(62,148.61)$

$(71,969.00)$

See notes to Table 1.20 . 
For federal deputies, in turn, the estimated upper bound on the effect on expenditures when running for the same position is statistically significant and similar to the estimates referring to the effect of incumbency as a state deputy on expenditures when running for federal deputy. However, the corresponding lower bound is statistically insignificant, hence we may not come to a definite conclusion in relation to the relevance of incumbency as a federal deputy on the ability to gather campaign funds to run for that position.

\subsubsection{Effects on Party Switching}

We now turn to investigating the incumbency effect on the probability of switching one's affiliation to another party. Despite the fact that candidates' (or, more generally, affiliated voters') political affiliations may be observed at any point in time, we are interested here in evaluating the connection between party switching and political career building, so we focus on analyzing the effect of holding office on the propensity to switch parties conditional on running again. ${ }^{50}$ This is accomplished by once again using the approach presented in Section 1.7, with one slight modification. We recall that in estimating a lower bound on the conditional effect on winning, the term $E\left(W_{0} \mid M=0, R_{1}>R_{0}\right)$ (i.e. the probability that a close complier would win a given position $p_{1}$ had he/she run for $p_{0}$ at $t$ and lost) in equation (1.3) was assumed to be at most the probability of winning presented by candidates who (narrowly) lost an election for position $p_{0}$ at $t$ and who actually ran for $p_{1}$ within four years; an analogous assumption was made when analyzing the conditional effect on campaign spending. However, we have no reason to believe that the probability of switching parties presented by that subset of compliers upon losing $p_{0}$ at $t$ should be smaller than the corresponding probability presented by any other group of candidates who run for $p_{0}$ at $t$ and for $p_{1}$ in $[t+1, t+4]$. Thus, in constructing the lower bound on the conditional effect on switching parties, we make the (most pessimistic) assumption that such probability equals one. As argued below, this assumption does not compromise our main qualitative conclusions, which are largely based on upper bound estimates.

The corresponding results are provided in Table 1.26. First, we observe from Panel A that incumbency as a city councilor is associated with a negative effect on party switching conditional on running again for the same position, since the related upper bound estimate is statistically significant and indicates that barely losers are at least 3 p.p. more likely than barely winners to switch parties in that situation. Regarding the effect conditional on running for another position, on the other hand, we do not find any conclusive evidence, as the estimated upper bound is statistically insignificant.

\footnotetext{
${ }^{50}$ In this spirit, our indicator of party switching is based on party affiliations exhibited in election years.
} 
In connection with the results for city councilors, we also find that incumbency as a mayor has a negative effect on the propensity to switch parties conditional on running again for the same position (in four years). As shown in Panel B, barely losers of mayoral elections are at least 13.26 p.p. more likely than barely winners to change parties when running for that position again after four years. However, we note that while the same conclusions are valid for candidates without recent political experience, experienced candidates are associated with lower and upper bounds estimates that are both positive but statistically insignificant, hence we do not reach any conclusions on the sign of that effect for that class of candidates. In particular, these results suggest the possibility that candidates at

Table 1.26: Incumbency Effects on Party Switching

(1)

Lower Bound Upper Bound

Panel A: City Councilor

Switching parties w/in 4 years (\%) |

$-15.82^{* * *}$

Running for the same position

$-37.67^{* * *}$

Switching parties w/in 4 years (\%) |

Running for another position

Panel B: First-Term Mayor

Switching parties w/in 4 years (\%) |

Running for the same position

Candidates without Recent Experience

Switching parties w/in 4 years (\%) |

Running for the same position

Candidates with Recent Experience

Switching parties w/in 4 years (\%) |

Running for the same position

Panel C: State Deputy

Switching parties w/in 4 years (\%) |

Running for the same position

Switching parties w/in 4 years $(\%) \mid$

Running for federal deputy

Panel D: Federal Deputy

Switching parties w/in 4 years (\%) |

$9.67^{* * *}$

Running for the same position 
the beginning of their political careers (e.g. candidates for city council and inexperienced candidates for mayor) may place the blame for their electoral defeats on their parties, and see party switching as a low-cost (in relation to their reputations) means to improve their electoral prospects and to succeed in their careers.

Similarly, when considering the effects of incumbency as a state deputy (Panel C), we find that barely losers are at least 21.06 p.p. more likely than barely winners to switch parties when running for the position of federal deputy. Nonetheless, the upper bound on the effect on switching parties conditional on running again for the same position is statistically insignificant, so we do not reject the hypothesis that such effect is equal to zero. In the same way, regarding candidates for federal deputy, there is no conclusive evidence on the incumbency effect on the probability of changing parties conditional on running again, since the corresponding estimates for the lower and upper bounds show different signs.

\subsection{Concluding Remarks}

In this article, we examine whether Brazilian politicians derive an incumbency advantage from holding office when running for reelection to the same held position as well as in the event of attempting to attain another elective office. We make use of quasi-random variation in the incumbency status of candidates for several positions to identify the causal electoral effects of incumbency, which is done through a regression discontinuity design based on close elections.

First, our results show that while incumbency of local offices is associated with negative or null impacts on the probability of being reelected to the same position - consistent with previous research on incumbency effects in developing countries - incumbents of legislative positions at the state and federal levels receive a positive and significant electoral advantage from officeholding when running for reelection. Thus, for the Brazilian context, we refute the commonly proposed hypothesis that incumbency disadvantages in new democracies may be a result of political or economic instabilities (at the national level). Moreover, in considering distinct local positions for different branches of government and subject to different electoral rules, we argue that the lack of positive incumbency effects for local offices may not be explained solely in terms of office-specific institutional constraints such as term limits. Rather, further exploration suggests that adverse effects of incumbency are only faced by relatively inexperienced officeholders, who arguably show some inability to respond to their constituents' needs and to take advantage of office resources in their reelection campaigns. Lastly, our investigation into cross-office incumbency ef- 
fects reveals that state deputies also derive an electoral advantage from incumbency when running for the lower house of congress. Along with the impacts from incumbency of state and federal legislative offices on winning the same position, this specific cross-office effect remains positive and large even after conditioning on running again.

In light of the recently escalating desire for electoral reforms manifested by civil society in Brazil, we particularly hope our analysis may provide further insight into the inner workings of political ambition and career formation, as well as on the level of accumulation of political power in that democracy. In particular, to the extent that the imposition of term limits (and electoral policies in general) is based on considerations about incumbency effects, our findings suggest that policymakers should be more concerned with career formation by legislators at higher levels of government than by local incumbents; in that sense, the imposition of constraints on transitions between elective offices could especially promote significant changes in the configuration of political activities and in relations between offices.

The results of this chapter also raise some interesting questions. As noted by Redmond and Regan (2015), candidates elected under proportional representation systems (such as legislators, in our case) are not as likely as those elected under plurality systems to rely upon some perquisites of office such as high media exposure and the ability to (individually) claim credit for the provision of public goods. Given the disparity between estimates for the different positions, it would thus be worthwhile investigating which officeholding benefits are available to (and effectively used in reelection campaigns by) incumbents of certain offices but not for others. Similarly, it becomes natural to wonder whether an electoral advantage received by incumbents when running for the same position is derived from the same benefits that are exploited in deriving an advantage when running for another office. Also, a more comprehensive assessment of the extent to which a political system encourages democratic participation should consider not only determinants of persistence in a political career but also the elements underlying people's decisions to become politicians. We leave these lines of questioning for future research.

\section{References for Chapter 1}

Ade, Florian, Ronny Freier, and Christian Odendahl (2014). "Incumbency effects in government and opposition: Evidence from Germany". European Journal of Political Economy, 36, pp. 117-134.

Aidt, Toke, Miriam A. Golden, and Devesh Tiwari (2011). "Incumbents and Criminals in the Indian National Legislature". Working Paper. 
Ames, Barry (2002). "Party Discipline in the Chamber of Deputies". In: Legislative Politics in Latin America. Ed. by S. Morgenstern and B. Nacif. New York: Cambridge University Press.

- (2009). The Deadlock of Democracy in Brazil. Ann Arbor: University of Michigan Press.

Anagol, Santosh and Thomas Fujiwara (2015). "The Runner-Up Effect". Working Paper. Angrist, Joshua D. and Jörn-Steffen Pischke (2008). Mostly Harmless Econometrics: An Empiricist's Companion. Princeton University Press.

Angrist, Joshua D., Guido W. Imbens, and Donald B. Rubin (1996). "Identification of Causal Effects Using Instrumental Variables". Journal of the American Statistical Association, 91(434), pp. 444-455.

Ansolabehere, Stephen, James M. Snyder Jr, and Charles Stewart III (2000). "Old Voters,

New Voters, and the Personal Vote: Using Redistricting to Measure the Incumbency Advantage". American Journal of Political Science, 44(1), pp. 17-34.

Blasnik, Michael (2010). "RECLINK: Stata Module to Probabilistically Match Records". Statistical Software Components.

Boas, Taylor C. and F. Daniel Hidalgo (2011). "Controlling the Airwaves: Incumbency Advantage and Community Radio in Brazil". American Journal of Political Science, 55(4), pp. 869-885.

Brace, Paul (1984). "Progressive Ambition in the House: A Probabilistic Approach". The Journal of Politics, 46(2), pp. 556-571.

Brambor, Thomas and Ricardo Ceneviva (2011). "Incumbency Advantage in Brazilian Mayoral Elections". Working Paper.

Carey, John (2002). "Parties, Coalitions, and the Chilean Congress in the 1990s". In: Legislative Politics in Latin America. Ed. by S. Morgenstern and B. Nacif. New York: Cambridge University Press.

Couto, Cláudio Gonçalves and Fernando Luiz Abrucio (1995). "Governando a Cidade? A Força e a Fraqueza da Câmara Municipal". São Paulo em Perspectiva, 9(2), pp. 57-65. Cox, Gary W. and Jonathan N. Katz (1996). "Why Did the Incumbency Advantage in U.S. House Elections Grow?" American Journal of Political Science, 40(2), pp. 478497.

De Janvry, Alain, Frederico Finan, and Elisabeth Sadoulet (2012). "Local Electoral Incentives and Decentralized Program Performance". Review of Economics and Statistics, 94(3), pp. 672-685.

Desposato, Scott W. (2006). "Parties for Rent? Ambition, Ideology, and Party Switching in Brazil's Chamber of Deputies". American Journal of Political Science, 50(1), pp. $62-$ 80 . 
Epstein, David, David Brady, Sadafumi Kawato, and Sharyn O. Halloran (1997). "A Comparative Approach to Legislative Organization: Careerism and Seniority in the United States and Japan". American Journal of Political Science, 41(3), pp. 965-998. Erikson, Robert S. (1971). "The Advantage of Incumbency in Congressional Elections". Polity, 3(3), pp. 395-405.

- (1972). "Malapportionment, Gerrymandering, and Party Fortunes in Congressional Elections". American Political Science Review, 66(4), pp. 1234-1245.

Ferraz, Claudio and Frederico Finan (2011). "Electoral Accountability and Corruption: Evidence from the Audits of Local Governments". American Economic Review, 101(4), pp. 1274-1311.

Ferreira, Fernando and Joseph Gyourko (2009). "Do Political Parties Matter? Evidence from U.S. Cities". The Quarterly Journal of Economics, 124(1), pp. 399-422.

Fiorina, Morris P. (1977). "The Case of the Vanishing Marginals: The Bureaucracy Did It". American Political Science Review, 71(1), pp. 177-181.

Freier, Ronny (2011). "Incumbency as the major advantage: The electoral advantage for parties of incumbent mayors". Working Paper.

Gemignani, Thomaz M. F. and Ricardo A. Madeira (2015). "Political Learning and Officials' Motivations: An Empirical Analysis of the Education Reform in the State of São Paulo". Working Paper.

Grossman, Gene M. and Elhanan Helpman (1996). "Electoral Competition and Special Interest Politics". The Review of Economic Studies, 63(2), pp. 265-286.

Hall, Richard L. and Robert P. Van Houweling (1995). "Avarice and Ambition in Congress: Representatives' Decisions to Run or Retire from the U.S. House". American Political Science Review, 89(1), pp. 121-136.

Heckman, James J. (1979). "Sample Selection Bias as a Specification Error". Econometrica, 47(1), pp. 153-162.

Herrick, Rebekah and Michael K. Moore (1993). "Political Ambition's Effect on Legislative Behavior: Schlesinger's Typology Reconsidered and Revised". The Journal of Politics, 55(3), pp. 765-776.

Herrick, Rebekah and David L. Nixon (1996). "Is There Life after Congress? Patterns and Determinants of Post-Congressional Careers". Legislative Studies Quarterly, 21(4), pp. 489-499.

Imbens, Guido W. and Karthik Kalyanaraman (2012). "Optimal Bandwidth Choice for the Regression Discontinuity Estimator". Review of Economic Studies, 79(3), pp. 933959.

Imbens, Guido W. and Thomas Lemieux (2008). "Regression Discontinuity Designs: A Guide to Practice". Journal of Econometrics, 142(2), pp. 615-635.

Jones, Mark P., Sebastian Saiegh, Pablo T. Spiller, and Mariano Tommasi (2002). "Amateur Legislators-Professional Politicians: The Consequences of Party-Centered Elec- 
toral Rules in a Federal System". American Journal of Political Science, 46(3), pp. 656669.

Kiewiet, D. Roderick and Langche Zeng (1993). "An Analysis of Congressional Career Decisions, 1947-1986". American Political Science Review, 87(4), pp. 928-941.

Kinzo, Maria D. and James Dunkerley (2003). Brazil Since 1985: Economy, Polity and Society. London: Institute of Latin American Studies, University of London.

Klašnja, Marko and Rocío Titiunik (2013). "Incumbency Disadvantage In Weak Party Systems: Evidence from Brazil". Working Paper.

Krehbiel, Keith and John R. Wright (1983). "The Incumbency Effect in Congressional Elections: A Test of Two Explanations". American Journal of Political Science, 27(1), pp. $140-157$.

Lee, David S. (2008). "Randomized experiments from non-random selection in U.S. House elections". Journal of Econometrics, 142(2), pp. 675-697.

- (2009). "Training, Wages, and Sample Selection: Estimating Sharp Bounds on Treatment Effects". The Review of Economic Studies, 76(3), pp. 1071-1102.

Lee, David S. and Thomas Lemieux (2010). "Regression Discontinuity Designs in Economics". Journal of Economic Literature, 48(2), pp. 281-355.

Leoni, Eduardo, Carlos Pereira, and Lúcio Rennó (2004). "Political Survival Strategies: Political Career Decisions in the Brazilian Chamber of Deputies". Journal of Latin American Studies, 36(1), pp. 109-130.

Levitt, Steven D. and Catherine D. Wolfram (1997). "Decomposing the Sources of Incumbency Advantage in the U.S. House". Legislative Studies Quarterly, 22(1), pp. 4560 .

Linden, Leigh (2004). "Are incumbents really advantaged? The preference for non-incumbents in Indian national elections". Unpublished Paper.

Macdonald, Bobbie (2014). "Incumbency Disadvantages in African Politics? Regression Discontinuity Evidence from Zambian Elections". Working Paper.

Mainwaring, Scott (1991). "Politicians, Parties, and Electoral Systems: Brazil in Comparative Perspective". Comparative Politics, 24(1), pp. 21-43.

— (1993). "Brazilian Party Underdevelopment in Comparative Perspective". Political Science Quarterly, 107(4), pp. 677-707.

Mayhew, David R. (1974). Congress: The Electoral Connection. Yale University Press.

McCrary, Justin (2008). "Manipulation of the running variable in the regression discontinuity design: A density test". Journal of Econometrics, 142(2), pp. 698-714.

Melo, Carlos Ranulfo Felix (2000). "Partidos e Migração Partidária na Câmara dos Deputados". Dados, 43(2).

Miguel, Edward and Farhan Zahidi (2004). "Do Politicians Reward their Supporters? Public Spending and Incumbency Advantage". Working Paper. 
Montero, Alfred P. (2005). Brazilian Politics: Reforming a Democratic State in a Changing World. Massachusetts: Polity Press.

Morgenstern, Scott (2002). "Towards a Model of Latin American Legislatures". In: Legislative Politics in Latin America. Ed. by S. Morgenstern and B. Nacif. New York: Cambridge University Press.

Nelson, Candice J. (1978). "The Effect of Incumbency on Voting in Congressional Elections, 1964-1974". Political Science Quarterly, 93(4), pp. 665-678.

Pereira, Carlos and Lúcio Rennó (2007). "O que é que o reeleito tem? O retorno: o esboço de uma teoria da reeleição no Brasil". Revista de Economia Política, 27(4), pp. 664683.

Polsby, Nelson W. (1968). "The Institutionalization of the U.S. House of Representatives". American Political Science Review, 62(1), pp. 144-168.

Power, Timothy J. and J. Timmons Roberts (1995). "Compulsory Voting, Invalid Ballots, and Abstention in Brazil". Political Research Quarterly, 48(4), pp. 795-826.

Redmond, Paul and John Regan (2015). "Incumbency advantage in a proportional electoral system: A regression discontinuity analysis of Irish elections". European Journal of Political Economy, 38, pp. 244-256.

Rohde, David W. (1979). "Risk-Bearing and Progressive Ambition: The Case of Members of the United States House of Representatives". American Journal of Political Science, 23(1), pp. 1-26.

Samuels, David J. (1998). "Political Ambition in Brazil, 1945-95: Theory and Evidence". Working Paper.

- (2000). "Ambition and Competition: Explaining Legislative Turnover in Brazil". Legislative Studies Quarterly, 25(3), pp. 481-497.

Schlesinger, Joseph A. (1966). Ambition and Politics: Political Careers in the United States. Chicago: Rand McNally.

Seabright, Paul (1996). "Accountability and Decentralisation in Government: An Incomplete Contracts Model". European Economic Review, 40(1), pp. 61-89.

Uppal, Yogesh (2009). "The Disadvantaged Incumbents: Estimating Incumbency Effects in Indian State Legislatures". Public Choice, 138(1), pp. 9-27. 


\section{Appendices to Chapter 1}

\section{A Data Construction}

This appendix describes in further detail the main challenges and procedures undertaken in constructing our panel of Brazilian election candidates. The original data for each election year was obtained from the website of the federal electoral authority (TSE). ${ }^{51}$

\section{A.1 Uniqueness by Election}

The first main issue arises from the fact that, regarding the database for a given election year, candidates' registration numbers may not uniquely identify observations. Inspection of the data reveals that this is due to two reasons: first, it is possible that two or more distinct candidates are associated with the same registration number (as a result of administrative errors). Also, and especially for the earlier years, the corresponding datasets presented some instances of missing values for registration numbers. Second, duplicates are also associated with candidates who filed more than one candidacy request (having abandoned or canceled previous requests).

These circumstances were dealt with by initially evaluating names and birth dates of individuals with the same registration number. Observations associated with the same registration number but displaying candidates' names and/or birth dates that were not sufficiently close were treated as referring to different candidates and given new (unique) values for the registration number; original values of registration numbers were kept under a different variable for future reference. Thus, for instance, the two observations from the 2012 dataset with registration number 53821380264 were treated as referring to the same candidate as the candidate's name was the same in both of them and the two corresponding values for birth dates differed only by what seemed to be a typographical error (26/08/1967 versus 26/08/1976). ${ }^{52}$ As another example, the two observations from the 2010 dataset with registration number 14109411872 (and birth date 01/02/1973) were treated as being associated with the same candidate, despite the fact that the can-

\footnotetext{
${ }^{51}$ http://www.tse.jus.br.

${ }^{52}$ Dates are displayed in the day/month/year format.
} 
didate's names were slightly different: "Soeli Dias de Oliveira Schneider" versus "Sueli Dias de Oliveira." On the other hand, the two observations with registration number 10839831864 (and birth date 31/01/1967) from the 2008 dataset were considered as referring to distinct candidates, as the candidates' names were completely different: "Maristela Mariana Ferreira de Alcantara" versus "Newton de Freitas Miotto."

Then, we proceeded to discarding the remaining duplicated observations - according to the (updated) registration number - so that only one observation per candidate would remain. Among the observations with the same registration number, priority (in remaining in the dataset) was given to those with non-missing data on electoral results and other characteristics of the candidates, and also took into account the correspondent candidacy status (accepted, rejected, canceled, etc.). In case duplicates remained after consideration of such aspects, the choice for the observation to be kept (from those with duplicated registration numbers) was based on the candidacy number generated by the electoral authority internal system. Table 1.A1 provides a description of the number of observations in each of the candidacy datasets before and after the aforementioned procedures, as well as the proportions of unique observations in the final datasets that had their registration numbers altered.

Table 1.A1: Incidence of Duplicated Registration Numbers, by Year

\begin{tabular}{|c|c|c|c|c|}
\hline \multirow{3}{*}{$\begin{array}{l}\text { Election } \\
\text { Year }\end{array}$} & (1) & $(2)$ & \multirow{3}{*}{$\begin{array}{l}\text { (3) } \\
\text { Number of } \\
\text { Altered Reg. } \\
\text { Numbers }\end{array}$} & \multirow{3}{*}{$\begin{array}{c}(4) \\
(3) /(2)(\%)\end{array}$} \\
\hline & \multicolumn{2}{|c|}{ Number of Observations } & & \\
\hline & Raw Data & $\begin{array}{l}\text { Discarding } \\
\text { Duplicates }\end{array}$ & & \\
\hline 1998 & 15,126 & 15,010 & 87 & 0.580 \\
\hline 2000 & 383,665 & 383,615 & 1,049 & 0.273 \\
\hline 2002 & 19,839 & 19,680 & 664 & 3.374 \\
\hline 2004 & 401,617 & 401,088 & 1,445 & 0.360 \\
\hline 2006 & 20,746 & 20,623 & 24 & 0.116 \\
\hline 2008 & 383,410 & 382,653 & 112 & 0.029 \\
\hline 2010 & 22,538 & 22,327 & 8 & 0.036 \\
\hline 2012 & 482,870 & 480,804 & 8 & 0.002 \\
\hline 2014 & 26,172 & 26,033 & 2 & 0.008 \\
\hline
\end{tabular}

\section{A.2 Matching Candidates across Elections}

Another important issue is matching candidates across election years, especially in light of the problems discussed above concerning candidates' registration numbers. Instead 


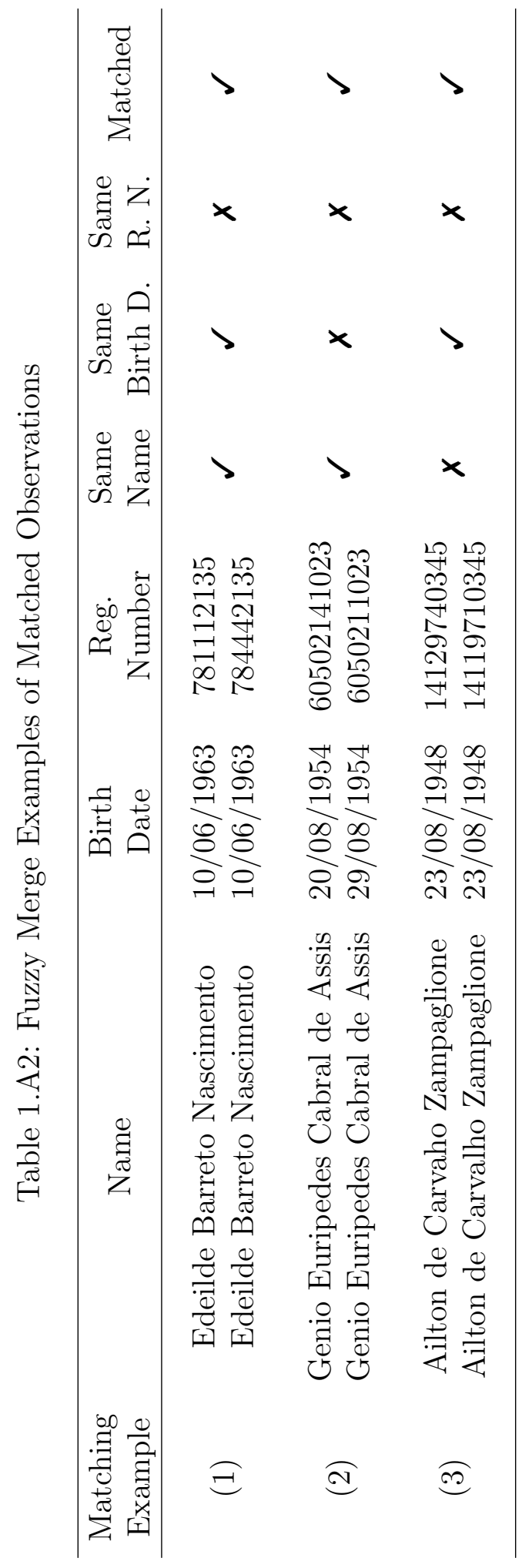


of relying on perfect matches of registration numbers to link candidates across time, we opted to implement this matching through a fuzzy merge procedure simultaneously considering candidates' registration numbers, names, and birth dates. This was done by using Stata command Reclink (Blasnik (2010)). Then, the decision over whether two linked observations did indeed refer to the same person was solely based on the generated matching score. Certain groups of linked individuals were defined according to the dimensions along which the corresponding matching was perfect or not, and different thresholds were adopted for each of those groups. For some groups, a second score was in some cases generated in order to evaluate the proximity of the information on candidates' birth municipalities and nicknames in the already linked observations. In those cases, this secondary score was used in conjunction with the primary score in evaluating the adequacy of performed matches. Table 1.A2 describes some examples of observations (from distinct elections) that were regarded as proper matches despite the fact that the corresponding candidates' registration numbers were not exactly the same. The final dataset contains $1,751,830$ observations at the election year/candidate level corresponding to $1,184,420$ individuals, of which $3,139(0.27 \%)$ present more than one distinct (original) registration number in the various elections for which they eventually run.

Lastly, in order to assess whether the occurrence of multiple-number individuals may be especially high for some positions, Table $1 . \mathrm{A} 3$ presents the number of people who eventually ran for each of the most relevant positions in the data, as well as the corresponding proportion of individuals with more than one registration number. While that proportion is somewhat more significant for state governors, it does not seem to be so for the positions considered in our RD analysis; hence, the particular procedures employed for matching candidates across elections and ensuring uniqueness at each election dataset are not expected to have an important role in driving our results.

Table 1.A3: Incidence of Individuals with Various Registration Numbers, by Position

\begin{tabular}{lccc}
\hline Position & $\begin{array}{c}\text { N. of eventual } \\
\text { candidates }\end{array}$ & $\begin{array}{c}\text { Eventual candidates w/ } \\
\text { more than one R.N. }\end{array}$ & $(2) /(1)(\%)$ \\
\hline City Councilor & $1,096,339$ & 2,876 & 0.26 \\
Mayor & 42,535 & 338 & 0.79 \\
State Deputy & 57,102 & 429 & 0.75 \\
Federal Deputy & 21,887 & 182 & 0.83 \\
State Governor & 730 & 18 & 2.47 \\
Senator & 1,065 & 18 & 1.69 \\
President & 34 & 0 & 0.00 \\
\hline All & $1,184,420$ & 3,139 & 0.27 \\
\hline
\end{tabular}




\section{B Additional Figures}

Figure 1.B1: McCrary Test - Distribution of Vote Share Margins, 1998-2010 elections
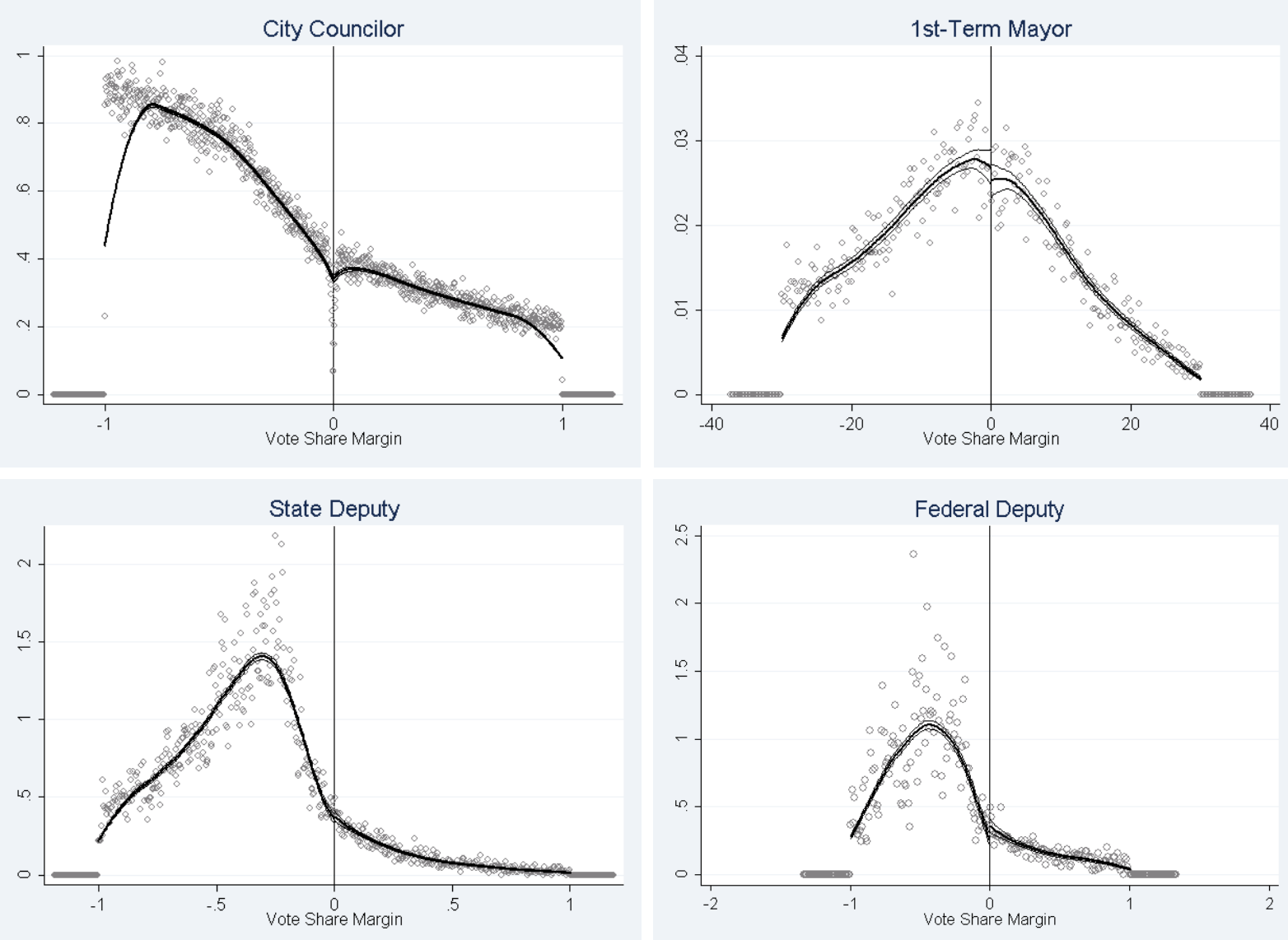

This figure is based on McCrary (2008) and derived from data on elections from 1998 to 2010. Solid thick lines represent estimates of the densities of vote share margins in each sample, and $95 \%$ confidence intervals are denoted by thin lines. 
Figure 1.B2: Graphical Representation of Main Results - City Councilor
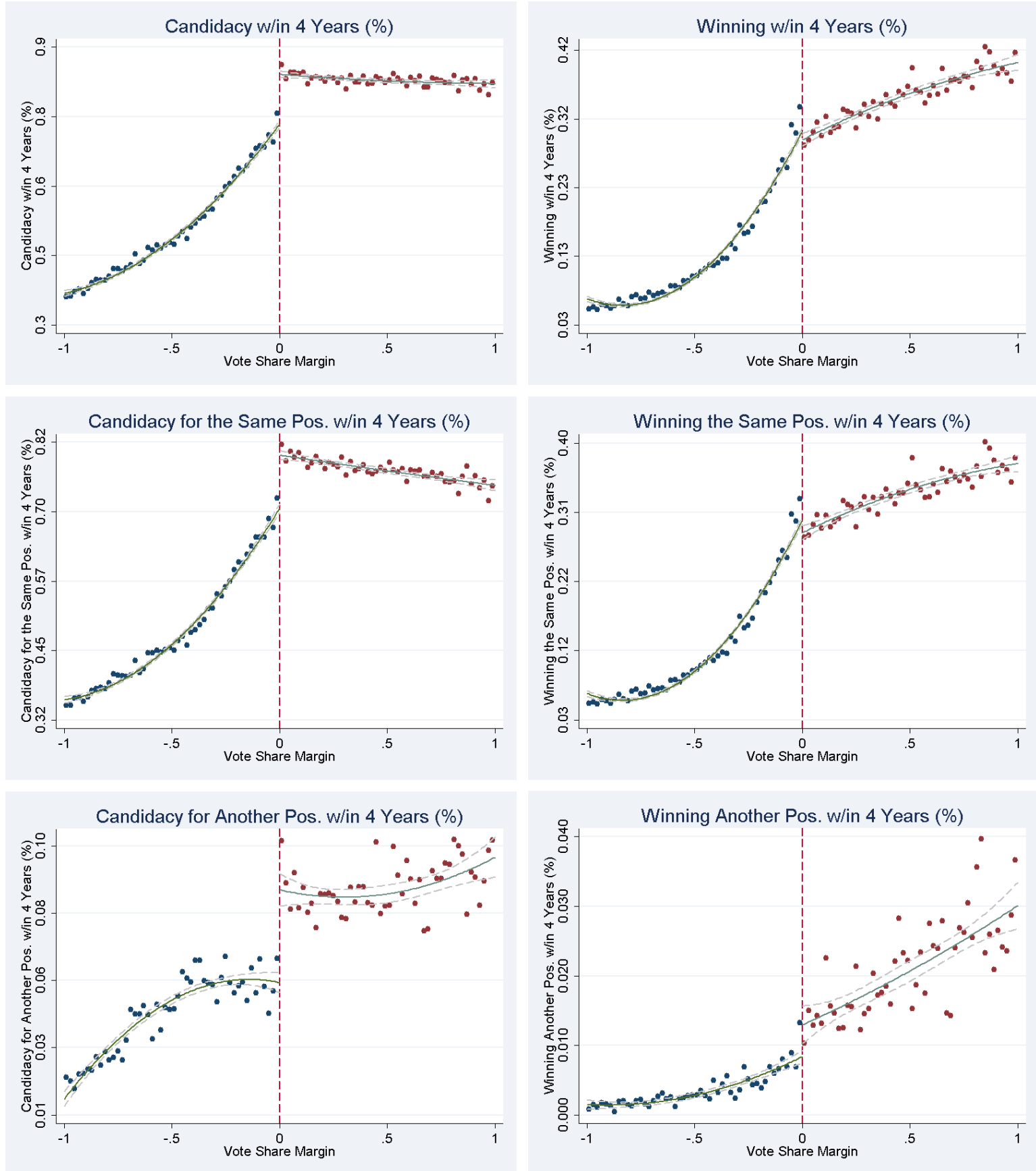

The dots represent mean values of the corresponding variables within $0.02 \%$ intervals of the vote share margin. Solid lines are fitted values of quadratic polynomial regressions on each side of the discontinuity threshold and dashed lines represent $95 \%$ confidence intervals. 
Figure 1.B3: Graphical Representation of Main Results - First-Term Mayor
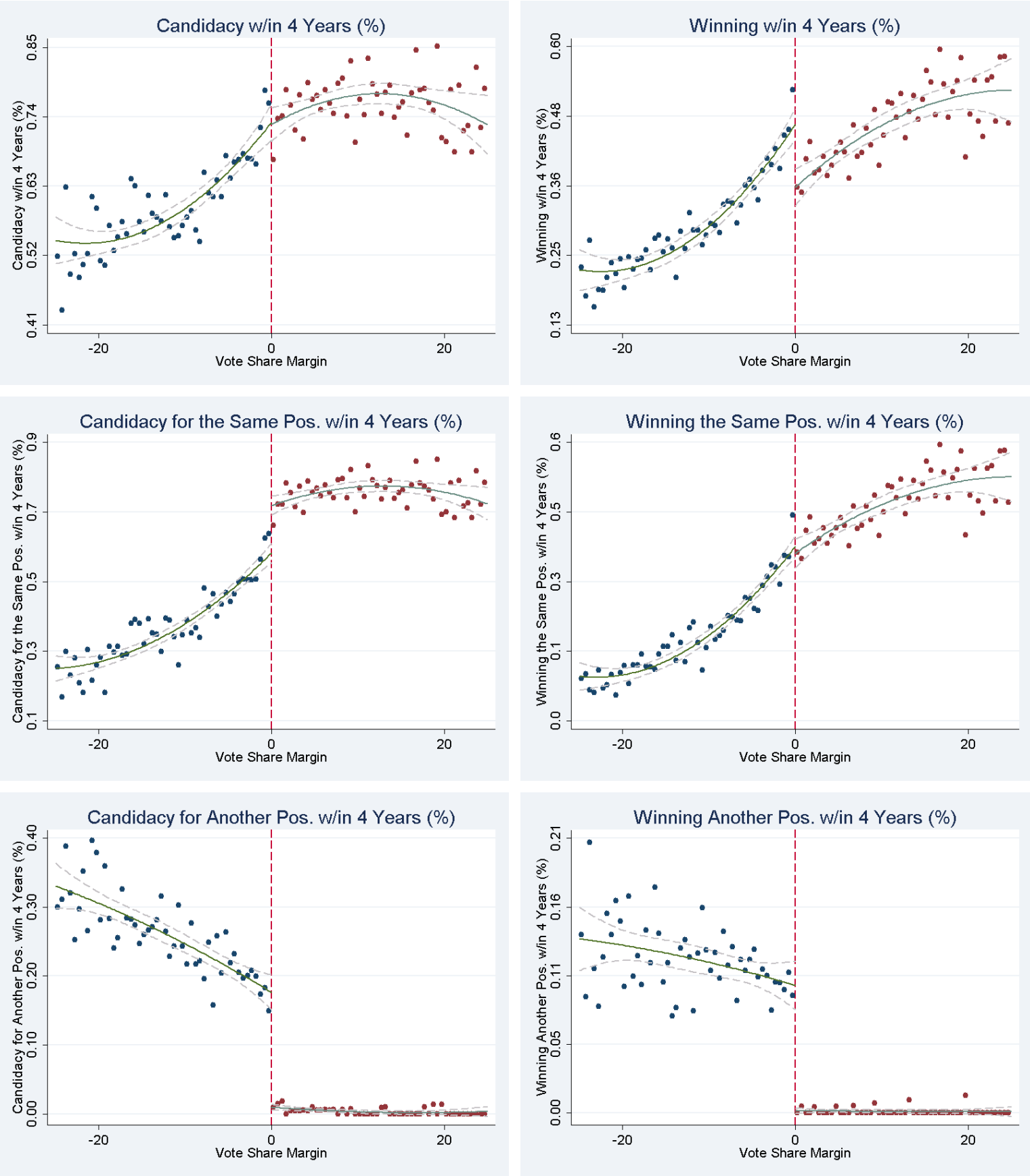

The dots represent mean values of the corresponding variables within $0.5 \%$ intervals of the vote share margin. Solid lines are fitted values of quadratic polynomial regressions on each side of the discontinuity threshold and dashed lines represent $95 \%$ confidence intervals. 
Figure 1.B4: Graphical Representation of Main Results - State Deputy
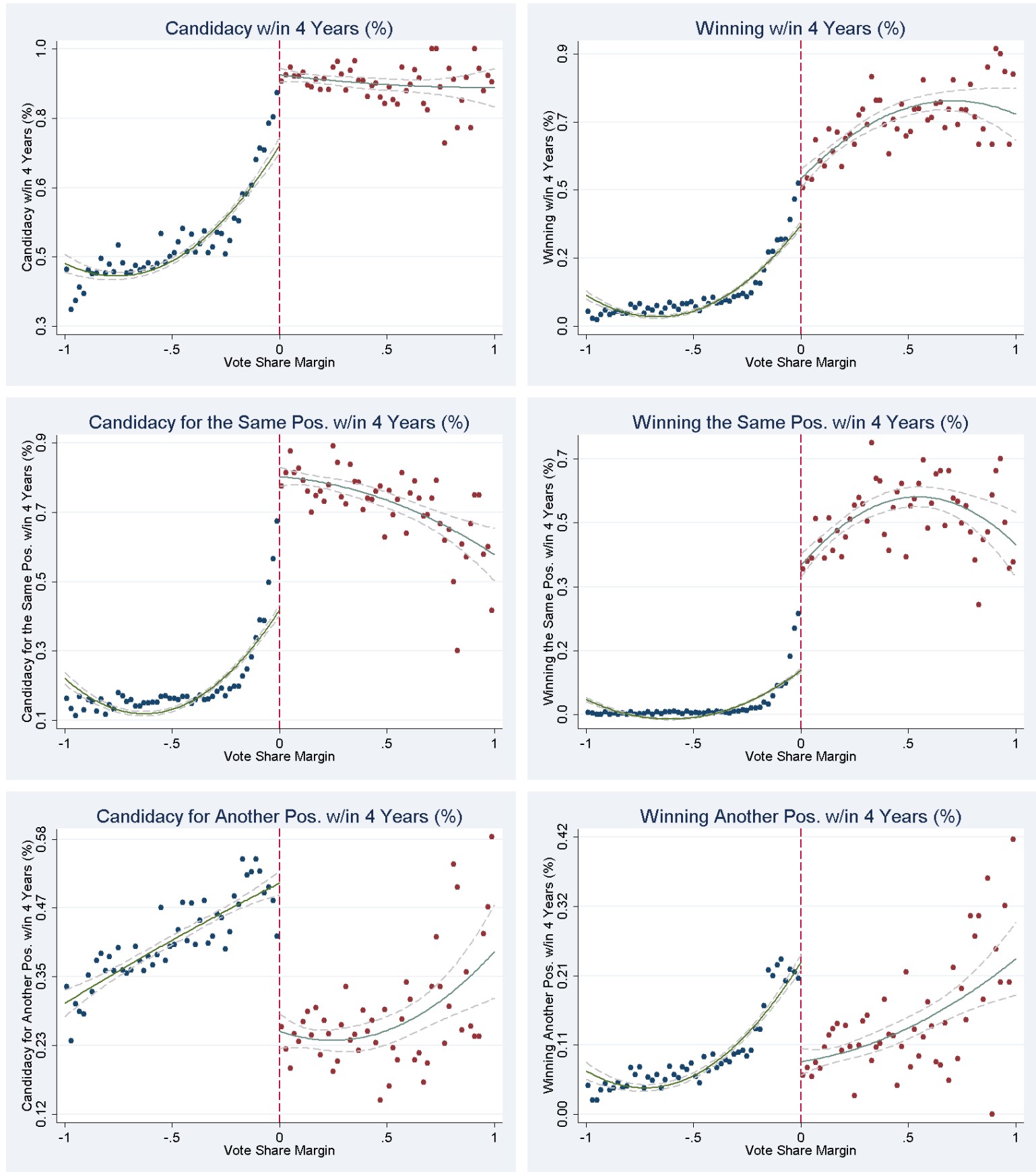

The dots represent mean values of the corresponding variables within $0.02 \%$ intervals of the vote share margin. Solid lines are fitted values of quadratic polynomial regressions on each side of the discontinuity threshold and dashed lines represent $95 \%$ confidence intervals. 
Figure 1.B5: Graphical Representation of Main Results - Federal Deputy
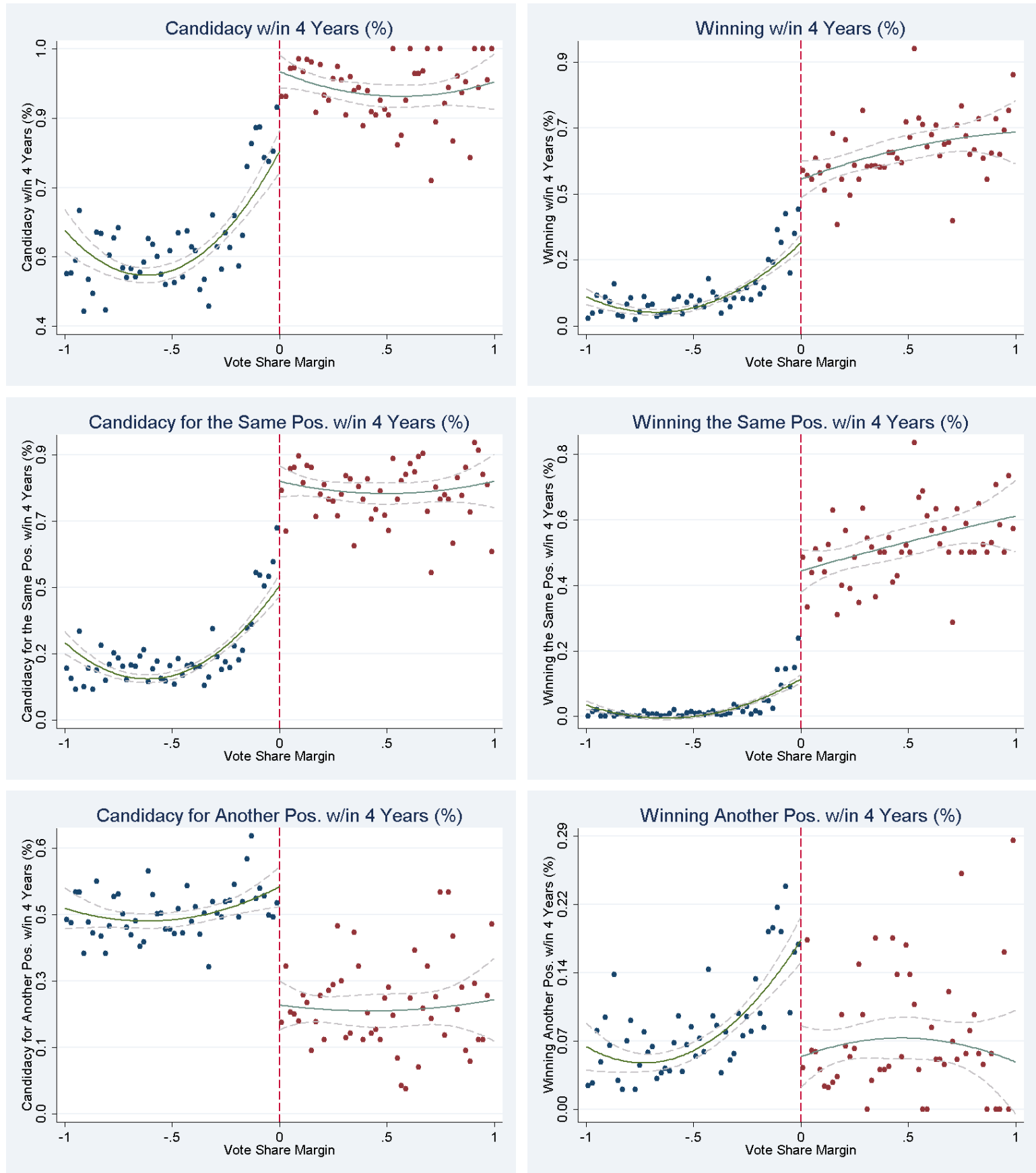

The dots represent mean values of the corresponding variables within $0.02 \%$ intervals of the vote share margin. Solid lines are fitted values of quadratic polynomial regressions on each side of the discontinuity threshold and dashed lines represent $95 \%$ confidence intervals. 


\section{C Additional Tables}

Table 1.C1: Migration across Offices and Retirement from Politics

\begin{tabular}{|c|c|c|c|}
\hline \multirow[b]{2}{*}{ Position Won } & \multirow{2}{*}{$\begin{array}{l}\text { Running Again } \\
\text { Before Term } \\
\text { Ends }\end{array}$} & \multicolumn{2}{|c|}{ Frequency (\%) } \\
\hline & & $\begin{array}{c}\text { Pooling } \\
\text { Mandates }\end{array}$ & $\begin{array}{l}\text { 1st-Time } \\
\text { Mandates }\end{array}$ \\
\hline \multirow{3}{*}{ City Councilor } & No & 17.40 & 23.66 \\
\hline & Yes, for the same position & 72.02 & 66.11 \\
\hline & Yes, for another position & 10.58 & 10.23 \\
\hline \multirow{3}{*}{ 1st-Term Mayor } & No & 24.97 & 23.40 \\
\hline & Yes, for the same position & 74.30 & 76.60 \\
\hline & Yes, for another position & 0.73 & 0.00 \\
\hline \multirow{3}{*}{ 2nd-Term Mayor } & No & 96.93 & \\
\hline & Yes, for the same position & 1.28 & \\
\hline & Yes, for another position & 1.79 & \\
\hline \multirow{3}{*}{ State Deputy } & No & 7.67 & 6.80 \\
\hline & Yes, for the same position & 65.72 & 69.90 \\
\hline & Yes, for another position & 26.61 & 23.30 \\
\hline \multirow{3}{*}{ Federal Deputy } & No & 7.80 & 0.00 \\
\hline & Yes, for the same position & 64.28 & 83.33 \\
\hline & Yes, for another position & 27.92 & 16.67 \\
\hline \multirow{3}{*}{ 1st-Term Governor } & No & 19.64 & $0.00 \dagger$ \\
\hline & Yes, for the same position & 67.86 & $75.00 \dagger$ \\
\hline & Yes, for another position & 12.50 & $25.00 \dagger$ \\
\hline \multirow{3}{*}{ 2nd-Term Governor } & No & $36.00 \dagger$ & \\
\hline & Yes, for the same position & $0.00 \dagger$ & \\
\hline & Yes, for another position & $64.00 \dagger$ & \\
\hline \multirow{3}{*}{ Senator } & No & 12.84 & $0.00 \dagger$ \\
\hline & Yes, for the same position & 28.44 & $18.18 \dagger$ \\
\hline & Yes, for another position & 58.72 & $81.82 \dagger$ \\
\hline \multirow{3}{*}{ All } & No & 21.07 & 23.94 \\
\hline & Yes, for the same position & 67.20 & 63.74 \\
\hline & Yes, for another position & 11.73 & 12.32 \\
\hline
\end{tabular}

See the notes to Table 1.2 
Table 1.C2: Tests of Quasi-Random Assignment - City Councilor

\begin{tabular}{|c|c|c|c|c|c|c|}
\hline & $\begin{array}{l}\text { Loser } \\
\text { Mean }\end{array}$ & $\begin{array}{l}\text { IKBW } \\
\{\text { obs }\}\end{array}$ & (1) & (2) & $(3)$ & (4) \\
\hline Gini & 0.554 & $\begin{array}{c}0.212 \\
\{47,425\}\end{array}$ & $\begin{array}{c}0.00013 \\
(0.00049)\end{array}$ & $\begin{array}{c}0.00049 \\
(0.00082)\end{array}$ & $\begin{array}{c}0.00012 \\
(0.00093)\end{array}$ & $\begin{array}{c}0.00017 \\
(0.00048)\end{array}$ \\
\hline HDI & 0.562 & $\begin{array}{c}0.197 \\
\{43,774\}\end{array}$ & $\begin{array}{c}0.00117 \\
(0.00089)\end{array}$ & $\begin{array}{c}-0.00399^{* *} \\
(0.00162)\end{array}$ & $\begin{array}{c}5.97 \mathrm{e}-05 \\
(0.00228)\end{array}$ & $\begin{array}{c}0.00123 \\
(0.00091)\end{array}$ \\
\hline Longitude & -46.30 & $\begin{array}{c}0.400 \\
\{96,054\}\end{array}$ & $\begin{array}{c}0.103 \\
(0.0770)\end{array}$ & $\begin{array}{c}0.0312 \\
(0.0774)\end{array}$ & $\begin{array}{c}0.0274 \\
(0.0661)\end{array}$ & $\begin{array}{c}0.0488 \\
(0.0470)\end{array}$ \\
\hline Latitude & -16.93 & $\begin{array}{c}0.400 \\
\{96,054\}\end{array}$ & $\begin{array}{l}0.0101 \\
(0.106)\end{array}$ & $\begin{array}{c}0.106 \\
(0.114)\end{array}$ & $\begin{array}{c}-0.0612 \\
(0.113)\end{array}$ & $\begin{array}{c}-0.0387 \\
(0.0640)\end{array}$ \\
\hline Log Electorate & 10.25 & $\begin{array}{c}0.145 \\
\{31,308\}\end{array}$ & $\begin{array}{l}-0.0375 \\
(0.0332)\end{array}$ & $\begin{array}{l}-0.0443 \\
(0.0357)\end{array}$ & $\begin{array}{c}0.0106 \\
(0.0714)\end{array}$ & $\begin{array}{c}0.0301^{*} \\
(0.0180)\end{array}$ \\
\hline Occupation: Agriculture (\%) & 12.29 & $\begin{array}{c}0.323 \\
\{75,548\}\end{array}$ & $\begin{array}{l}-0.42 \\
(0.45)\end{array}$ & $\begin{array}{c}1.56 \\
(1.20)\end{array}$ & $\begin{array}{c}0.37 \\
(0.82)\end{array}$ & $\begin{array}{c}0.02 \\
(0.57)\end{array}$ \\
\hline Occupation: Teaching (\%) & 6.04 & $\begin{array}{c}0.400 \\
\{96,054\}\end{array}$ & $\begin{array}{c}0.33 \\
(0.32)\end{array}$ & $\begin{array}{l}-1.52 \\
(1.11)\end{array}$ & $\begin{array}{l}-0.02 \\
(0.70)\end{array}$ & $\begin{array}{l}-0.45 \\
(0.45)\end{array}$ \\
\hline Secondary Education (\%) & 55.97 & $\begin{array}{c}0.356 \\
\{84,105\}\end{array}$ & $\begin{array}{l}-0.11 \\
(0.69)\end{array}$ & $\begin{array}{l}-0.49 \\
(2.23)\end{array}$ & $\begin{array}{c}0.26 \\
(1.43)\end{array}$ & $\begin{array}{l}-0.65 \\
(0.90)\end{array}$ \\
\hline Single (\%) & 18.67 & $\begin{array}{c}0.400 \\
\{96,054\}\end{array}$ & $\begin{array}{l}-0.85 \\
(0.56)\end{array}$ & $\begin{array}{l}-0.95 \\
(1.77)\end{array}$ & $\begin{array}{l}-1.40 \\
(1.18)\end{array}$ & $\begin{array}{l}-1.40^{*} \\
(0.80)\end{array}$ \\
\hline Age (years) & 43.85 & $\begin{array}{c}0.400 \\
\{96,054\}\end{array}$ & $\begin{array}{c}0.101 \\
(0.139)\end{array}$ & $\begin{array}{c}0.404 \\
(0.440)\end{array}$ & $\begin{array}{r}-0.0617 \\
(0.292)\end{array}$ & $\begin{array}{c}0.126 \\
(0.196)\end{array}$ \\
\hline Party: PMDB (\%) & 14.69 & $\begin{array}{c}0.383 \\
\{91,298\}\end{array}$ & $\begin{array}{l}-0.61^{*} \\
(0.35)\end{array}$ & $\begin{array}{l}-0.86 \\
(0.93)\end{array}$ & $\begin{array}{l}-0.36 \\
(0.66)\end{array}$ & $\begin{array}{l}-0.27 \\
(0.43)\end{array}$ \\
\hline Party: PSDB (\%) & 10.94 & $\begin{array}{c}0.400 \\
\{96,054\}\end{array}$ & $\begin{array}{c}0.75^{* *} \\
(0.37)\end{array}$ & $\begin{array}{c}0.86 \\
(0.84)\end{array}$ & $\begin{array}{c}0.21 \\
(0.60)\end{array}$ & $\begin{array}{c}0.51 \\
(0.42)\end{array}$ \\
\hline Party: PT (\%) & 8.00 & $\begin{array}{c}0.400 \\
\{96,054\}\end{array}$ & $\begin{array}{c}0.19 \\
(0.34)\end{array}$ & $\begin{array}{c}1.28 \\
(0.82)\end{array}$ & $\begin{array}{c}0.17 \\
(0.53)\end{array}$ & $\begin{array}{l}-0.34 \\
(0.35)\end{array}$ \\
\hline Number of Seats & 12.54 & $\begin{array}{c}0.299 \\
\{69,433\}\end{array}$ & $\begin{array}{c}0.392 \\
(0.282)\end{array}$ & $\begin{array}{l}-0.376 \\
(0.239)\end{array}$ & $\begin{array}{c}-0.0776 \\
(0.505)\end{array}$ & $\begin{array}{c}0.167^{*} \\
(0.0979)\end{array}$ \\
\hline $\begin{array}{l}\text { Number of Candidates } \\
\text { in the Coalition }\end{array}$ & 19.21 & $\begin{array}{c}0.252 \\
\{57,389\}\end{array}$ & $\begin{array}{c}0.385 \\
(0.686)\end{array}$ & $\begin{array}{r}-0.0822 \\
(0.182)\end{array}$ & $\begin{array}{c}0.276 \\
(0.686)\end{array}$ & $\begin{array}{c}0.234 \\
(0.173)\end{array}$ \\
\hline $\begin{array}{l}\text { Number of Candidates } \\
\text { in the Electoral Unit }\end{array}$ & 133.2 & $\begin{array}{c}0.295 \\
\{68,392\}\end{array}$ & $\begin{array}{c}9.513 \\
(8.683)\end{array}$ & $\begin{array}{l}-7.888 \\
(5.227)\end{array}$ & $\begin{array}{c}0.708 \\
(12.61)\end{array}$ & $\begin{array}{l}4.522^{*} \\
(2.372)\end{array}$ \\
\hline $\begin{array}{l}\text { Bandwidth } \\
\text { Observations }\end{array}$ & & & $\begin{array}{c}\text { IKBW } \\
-\end{array}$ & $\begin{array}{c}0.05 \% \\
9,738\end{array}$ & $\begin{array}{c}0.1 \% \\
20,949\end{array}$ & $\begin{array}{c}0.2 \% \\
44,546\end{array}$ \\
\hline
\end{tabular}

All notes to Table 1.9 apply. 
Table 1.C3: Tests of Quasi-Random Assignment - First-Term Mayor

\begin{tabular}{|c|c|c|c|c|c|c|}
\hline & $\begin{array}{l}\text { Loser } \\
\text { Mean }\end{array}$ & $\begin{array}{c}\text { IKBW } \\
\{\text { obs }\}\end{array}$ & (1) & (2) & (3) & (4) \\
\hline Gini & 0.553 & $\begin{array}{l}0.964 \\
\{821\}\end{array}$ & $\begin{array}{l}0.000600 \\
(0.00590)\end{array}$ & $\begin{array}{c}3.43 \mathrm{e}-05 \\
(0.00607)\end{array}$ & $\begin{array}{c}0.00523^{* *} \\
(0.00239)\end{array}$ & $\begin{array}{l}-5.75 \mathrm{e}-05 \\
(0.00174)\end{array}$ \\
\hline HDI & 0.508 & $\begin{array}{l}1.178 \\
\{962\}\end{array}$ & $\begin{array}{c}0.00669 \\
(0.00775)\end{array}$ & $\begin{array}{l}0.000403 \\
(0.00853)\end{array}$ & $\begin{array}{c}0.00219 \\
(0.00346)\end{array}$ & $\begin{array}{c}0.00361 \\
(0.00247)\end{array}$ \\
\hline Longitude & -46.52 & $\begin{array}{c}3.980 \\
\{3,379\}\end{array}$ & $\begin{array}{c}0.153 \\
(0.248)\end{array}$ & $\begin{array}{c}0.291 \\
(0.492)\end{array}$ & $\begin{array}{l}-0.0158 \\
(0.222)\end{array}$ & $\begin{array}{l}-0.162 \\
(0.155)\end{array}$ \\
\hline Latitude & -16.54 & $\begin{array}{c}4.088 \\
\{3,478\}\end{array}$ & $\begin{array}{l}-0.0871 \\
(0.332)\end{array}$ & $\begin{array}{l}0.0289 \\
(0.726)\end{array}$ & $\begin{array}{l}-0.213 \\
(0.297)\end{array}$ & $\begin{array}{l}-0.242 \\
(0.213)\end{array}$ \\
\hline Log Electorate & 9.024 & $\begin{array}{c}1.963 \\
\{1,594\}\end{array}$ & $\begin{array}{l}-0.0205 \\
(0.0487)\end{array}$ & $\begin{array}{l}-0.0603 \\
(0.0725)\end{array}$ & $\begin{array}{l}-0.00677 \\
(0.0324)\end{array}$ & $\begin{array}{c}0.0268 \\
(0.0240)\end{array}$ \\
\hline Occupation: Agriculture (\%) & 13.4 & $\begin{array}{c}1.627 \\
\{1,298\}\end{array}$ & $\begin{array}{l}-0.12 \\
(3.51)\end{array}$ & $\begin{array}{l}1.85 \\
(4.58)\end{array}$ & $\begin{array}{c}0.48 \\
(1.88)\end{array}$ & $\begin{array}{c}0.88 \\
(1.34)\end{array}$ \\
\hline Occupation: Teaching (\%) & 5.86 & $\begin{array}{c}1.422 \\
\{1,151\}\end{array}$ & $\begin{array}{c}0.15 \\
(2.65)\end{array}$ & $\begin{array}{c}3.67 \\
(3.28)\end{array}$ & $\begin{array}{c}1.09 \\
(1.49)\end{array}$ & $\begin{array}{l}1.29 \\
(1.04)\end{array}$ \\
\hline Secondary Education (\%) & 76.49 & $\begin{array}{c}1.769 \\
\{1,402\}\end{array}$ & $\begin{array}{l}-3.58 \\
(4.48)\end{array}$ & $\begin{array}{l}-3.14 \\
(6.09)\end{array}$ & $\begin{array}{c}0.30 \\
(2.62)\end{array}$ & $\begin{array}{c}1.38 \\
(1.86)\end{array}$ \\
\hline Single $(\%)$ & 7.65 & $\begin{array}{c}1.365 \\
\{1,109\}\end{array}$ & $\begin{array}{l}-2.75 \\
(3.65)\end{array}$ & $\begin{array}{l}-3.50 \\
(4.09)\end{array}$ & $\begin{array}{l}-3.71^{*} \\
(1.91)\end{array}$ & $\begin{array}{l}-2.48^{*} \\
(1.40)\end{array}$ \\
\hline Age (years) & 47.57 & $\begin{array}{c}4.308 \\
\{3,665\}\end{array}$ & $\begin{array}{c}0.410 \\
(0.670)\end{array}$ & $\begin{array}{c}0.260 \\
(1.507)\end{array}$ & $\begin{array}{c}0.465 \\
(0.618)\end{array}$ & $\begin{array}{c}0.207 \\
(0.439)\end{array}$ \\
\hline Party: PMDB (\%) & 23.32 & $\begin{array}{c}1.396 \\
\{1,124\}\end{array}$ & $\begin{array}{c}0.49 \\
(5.64)\end{array}$ & $\begin{array}{l}-6.38 \\
(6.92)\end{array}$ & $\begin{array}{l}-1.29 \\
(2.70)\end{array}$ & $\begin{array}{l}-1.94 \\
(1.88)\end{array}$ \\
\hline Party: PSDB (\%) & 13.38 & $\begin{array}{c}1.697 \\
\{1,347\}\end{array}$ & $\begin{array}{l}1.50 \\
(3.94)\end{array}$ & $\begin{array}{l}-0.07 \\
(5.20)\end{array}$ & $\begin{array}{l}3.95^{*} \\
(2.26)\end{array}$ & $\begin{array}{l}3.02^{*} \\
(1.60)\end{array}$ \\
\hline Party: PT (\%) & 9.34 & $\begin{array}{c}1.403 \\
\{1,138\}\end{array}$ & $\begin{array}{c}4.37 \\
(3.58)\end{array}$ & $\begin{array}{c}5.98 \\
(4.57)\end{array}$ & $\begin{array}{c}1.26 \\
(1.88)\end{array}$ & $\begin{array}{c}1.87 \\
(1.29)\end{array}$ \\
\hline $\begin{array}{l}\text { Number of Candidates } \\
\text { in the Electoral Unit }\end{array}$ & 2.730 & $\begin{array}{c}1.903 \\
\{1,529\}\end{array}$ & $\begin{array}{l}-0.0623 \\
(0.0490)\end{array}$ & $\begin{array}{c}-0.138^{* *} \\
(0.0664)\end{array}$ & $\begin{array}{l}0.00460 \\
(0.0351)\end{array}$ & $\begin{array}{c}0.0127 \\
(0.0250)\end{array}$ \\
\hline Bandwidth & & & & $1 \%$ & $5 \%$ & $10 \%$ \\
\hline Observations & & & & 838 & 4,293 & 8,013 \\
\hline
\end{tabular}

All notes to Table 1.10 apply. 
Table 1.C4: Tests of Quasi-Random Assignment - State Deputy

\begin{tabular}{|c|c|c|c|c|c|c|}
\hline & $\begin{array}{l}\text { Loser } \\
\text { Mean }\end{array}$ & $\begin{array}{l}\text { IKBW } \\
\text { obs }\}\end{array}$ & (1) & $(2)$ & (3) & (4) \\
\hline Gini & 0.604 & $\begin{array}{c}0.121 \\
\{3,408\}\end{array}$ & $\begin{array}{c}-0.00199 \\
(0.00141)\end{array}$ & $\begin{array}{c}-0.00039 \\
(0.00149)\end{array}$ & $\begin{array}{c}-0.00232 \\
(0.00170)\end{array}$ & $\begin{array}{c}0.00144 \\
(0.00270)\end{array}$ \\
\hline HDI & 0.605 & $\begin{array}{c}0.167 \\
\{5,067\}\end{array}$ & $\begin{array}{l}-0.00097 \\
(0.00504)\end{array}$ & $\begin{array}{c}0.0104^{*} \\
(0.00540)\end{array}$ & $\begin{array}{c}0.00414 \\
(0.00689)\end{array}$ & $\begin{array}{c}0.00849 \\
(0.00550)\end{array}$ \\
\hline Longitude & -46.13 & $\begin{array}{c}0.298 \\
\{12,268\}\end{array}$ & $\begin{array}{c}0.446 \\
(0.295)\end{array}$ & $\begin{array}{c}0.374 \\
(0.432)\end{array}$ & $\begin{array}{c}0.383 \\
(0.439)\end{array}$ & $\begin{array}{c}0.262 \\
(0.309)\end{array}$ \\
\hline Latitude & -17.26 & $\begin{array}{c}0.167 \\
\{5,062\}\end{array}$ & $\begin{array}{c}0.371 \\
(0.394)\end{array}$ & $\begin{array}{l}-0.269 \\
(0.388)\end{array}$ & $\begin{array}{c}0.249 \\
(0.300)\end{array}$ & $\begin{array}{c}0.229 \\
(0.416)\end{array}$ \\
\hline Log Electorate & 15.62 & $\begin{array}{c}0.120 \\
\{3,357\}\end{array}$ & $\begin{array}{c}0.0135 \\
(0.0682)\end{array}$ & $\begin{array}{c}0.114^{* *} \\
(0.0449)\end{array}$ & $\begin{array}{c}0.0207 \\
(0.0704)\end{array}$ & $\begin{array}{c}0.00749 \\
(0.0776)\end{array}$ \\
\hline Occupation: Agriculture (\%) & 0.75 & $\begin{array}{c}0.400 \\
\{17,506\}\end{array}$ & $\begin{array}{c}0.22 \\
(0.38)\end{array}$ & $\begin{array}{l}-1.69 \\
(1.17)\end{array}$ & $\begin{array}{l}-1.25 \\
(0.94)\end{array}$ & $\begin{array}{l}-0.32 \\
(0.55)\end{array}$ \\
\hline Occupation: Teaching (\%) & 5.04 & $\begin{array}{c}0.400 \\
\{17,506\}\end{array}$ & $\begin{array}{l}-1.21 \\
(0.73)\end{array}$ & $\begin{array}{l}-1.03 \\
(1.71)\end{array}$ & $\begin{array}{l}-0.88 \\
(1.34)\end{array}$ & $\begin{array}{l}-0.27 \\
(1.04)\end{array}$ \\
\hline Secondary Education (\%) & 92.91 & $\begin{array}{c}0.229 \\
\{8,281\}\end{array}$ & $\begin{array}{l}-0.39 \\
(1.30)\end{array}$ & $\begin{array}{c}0.59 \\
(2.61)\end{array}$ & $\begin{array}{c}0.40 \\
(2.02)\end{array}$ & $\begin{array}{c}0.49 \\
(1.38)\end{array}$ \\
\hline Single $(\%)$ & 12.22 & $\begin{array}{c}0.240 \\
\{8,910\}\end{array}$ & $\begin{array}{c}0.65 \\
(1.44)\end{array}$ & $\begin{array}{c}3.39 \\
(5.40)\end{array}$ & $\begin{array}{l}-0.57 \\
(3.49)\end{array}$ & $\begin{array}{l}-0.70 \\
(1.83)\end{array}$ \\
\hline Age (years) & 47.25 & $\begin{array}{c}0.400 \\
\{17,506\}\end{array}$ & $\begin{array}{c}0.670 \\
(0.412)\end{array}$ & $\begin{array}{l}-1.523 \\
(0.912)\end{array}$ & $\begin{array}{l}-0.576 \\
(0.690)\end{array}$ & $\begin{array}{l}-0.261 \\
(0.416)\end{array}$ \\
\hline Party: PMDB (\%) & 8.96 & $\begin{array}{c}0.266 \\
\{10,607\}\end{array}$ & $\begin{array}{l}3.59^{*} \\
(1.87)\end{array}$ & $\begin{array}{c}3.67 \\
(2.18)\end{array}$ & $\begin{array}{l}3.55^{*} \\
(1.75)\end{array}$ & $\begin{array}{c}3.36^{* *} \\
(1.41)\end{array}$ \\
\hline Party: PSDB (\%) & 11.96 & $\begin{array}{c}0.233 \\
\{8,529\}\end{array}$ & $\begin{array}{l}-0.05 \\
(1.02)\end{array}$ & $\begin{array}{l}-3.26 \\
(1.94)\end{array}$ & $\begin{array}{l}-1.70 \\
(1.92)\end{array}$ & $\begin{array}{l}-0.63 \\
(1.29)\end{array}$ \\
\hline Party: PT (\%) & 10.91 & $\begin{array}{c}0.345 \\
\{14,878\}\end{array}$ & $\begin{array}{l}2.15 \\
(2.17)\end{array}$ & $\begin{array}{c}0.09 \\
(2.08)\end{array}$ & $\begin{array}{l}-0.17 \\
(1.87)\end{array}$ & $\begin{array}{c}0.81 \\
(1.63)\end{array}$ \\
\hline Number of Seats & 58.15 & $\begin{array}{c}0.115 \\
\{3,193\}\end{array}$ & $\begin{array}{l}-0.370 \\
(1.407)\end{array}$ & $\begin{array}{c}1.994^{* *} \\
(0.873)\end{array}$ & $\begin{array}{c}-0.261 \\
(1.282)\end{array}$ & $\begin{array}{c}-0.538 \\
(1.961)\end{array}$ \\
\hline $\begin{array}{l}\text { Number of Candidates } \\
\text { in the Coalition }\end{array}$ & 69.60 & $\begin{array}{c}0.129 \\
\{3,663\}\end{array}$ & $\begin{array}{c}1.039 \\
(1.243)\end{array}$ & $\begin{array}{l}-2.523 \\
(2.949)\end{array}$ & $\begin{array}{c}2.011 \\
(1.880)\end{array}$ & $\begin{array}{c}4.333^{* * *} \\
(0.801)\end{array}$ \\
\hline $\begin{array}{l}\text { Number of Candidates } \\
\text { in the Electoral Unit }\end{array}$ & 731.2 & $\begin{array}{c}0.130 \\
\{3,684\}\end{array}$ & $\begin{array}{l}-18.34 \\
(36.85)\end{array}$ & $\begin{array}{l}33.41^{*} \\
(17.79)\end{array}$ & $\begin{array}{l}-10.61 \\
(23.45)\end{array}$ & $\begin{array}{l}-19.10 \\
(27.32)\end{array}$ \\
\hline Bandwidth & & & & $0.05 \%$ & $0.1 \%$ & $0.2 \%$ \\
\hline Observations & & & & 1,357 & 2,763 & 6,665 \\
\hline
\end{tabular}

All notes to Table 1.9 apply. 
Table 1.C5: Tests of Quasi-Random Assignment - Federal Deputy

\begin{tabular}{|c|c|c|c|c|c|c|}
\hline & $\begin{array}{l}\text { Loser } \\
\text { Mean }\end{array}$ & $\begin{array}{c}\text { IKBW } \\
\{\text { obs }\}\end{array}$ & (1) & $(2)$ & (3) & $(4)$ \\
\hline Gini & 0.590 & $\begin{array}{c}0.321 \\
\{2,497\}\end{array}$ & $\begin{array}{c}0.00256 \\
(0.00229)\end{array}$ & $\begin{array}{c}0.00019 \\
(0.00184)\end{array}$ & $\begin{array}{c}0.00114 \\
(0.00216)\end{array}$ & $\begin{array}{c}0.00197 \\
(0.00154)\end{array}$ \\
\hline HDI & 0.650 & $\begin{array}{c}0.336 \\
\{2,664\}\end{array}$ & $\begin{array}{c}-0.0185^{* *} \\
(0.00797)\end{array}$ & $\begin{array}{c}0.00793 \\
(0.00834)\end{array}$ & $\begin{array}{c}-0.00531 \\
(0.00927)\end{array}$ & $\begin{array}{c}-0.0139^{* *} \\
(0.00547)\end{array}$ \\
\hline Longitude & -45.50 & $\begin{array}{c}0.400 \\
\{3,275\}\end{array}$ & $\begin{array}{c}0.184 \\
(0.426)\end{array}$ & $\begin{array}{c}0.547 \\
(0.395)\end{array}$ & $\begin{array}{c}0.344 \\
(0.342)\end{array}$ & $\begin{array}{c}0.105 \\
(0.225)\end{array}$ \\
\hline Latitude & -21.42 & $\begin{array}{c}0.343 \\
\{2,710\}\end{array}$ & $\begin{array}{c}0.905^{* *} \\
(0.387)\end{array}$ & $\begin{array}{c}0.254 \\
(0.421)\end{array}$ & $\begin{array}{c}0.428 \\
(0.444)\end{array}$ & $\begin{array}{c}-0.119 \\
(0.343)\end{array}$ \\
\hline Log Electorate & 16.40 & $\begin{array}{c}0.324 \\
\{2,558\}\end{array}$ & $\begin{array}{c}-0.108^{* *} \\
(0.0497)\end{array}$ & $\begin{array}{l}0.0736^{*} \\
(0.0394)\end{array}$ & $\begin{array}{c}-0.0870^{*} \\
(0.0492)\end{array}$ & $\begin{array}{c}-0.0265 \\
(0.0616)\end{array}$ \\
\hline Occupation: Agriculture (\%) & 0.59 & $\begin{array}{c}0.400 \\
\{3,275\}\end{array}$ & $\begin{array}{l}-0.05 \\
(0.75)\end{array}$ & $\begin{array}{l}-1.70 \\
(1.85)\end{array}$ & $\begin{array}{l}-2.05 \\
(1.45)\end{array}$ & $\begin{array}{l}-0.44 \\
(0.94)\end{array}$ \\
\hline Occupation: Teaching (\%) & 3.69 & $\begin{array}{c}0.400 \\
\{3,275\}\end{array}$ & $\begin{array}{c}2.20 \\
(2.18)\end{array}$ & $\begin{array}{l}-2.86 \\
(4.62)\end{array}$ & $\begin{array}{c}0.39 \\
(3.71)\end{array}$ & $\begin{array}{c}2.58 \\
(4.00)\end{array}$ \\
\hline Secondary Education (\%) & 94.80 & $\begin{array}{c}0.400 \\
\{3,275\}\end{array}$ & $\begin{array}{c}0.40 \\
(2.30)\end{array}$ & $\begin{array}{c}4.76 \\
(3.92)\end{array}$ & $\begin{array}{c}10.55^{* * *} \\
(2.50)\end{array}$ & $\begin{array}{c}2.74^{* *} \\
(1.14)\end{array}$ \\
\hline Single $(\%)$ & 11.39 & $\begin{array}{c}0.400 \\
\{3,275\}\end{array}$ & $\begin{array}{l}-1.54 \\
(3.21)\end{array}$ & $\begin{array}{c}3.63 \\
(4.79)\end{array}$ & $\begin{array}{c}3.55 \\
(3.18)\end{array}$ & $\begin{array}{c}4.25 \\
(2.93)\end{array}$ \\
\hline Age (years) & 49.55 & $\begin{array}{c}0.400 \\
\{3,275\}\end{array}$ & $\begin{array}{c}1.253^{* * *} \\
(0.425)\end{array}$ & $\begin{array}{l}-2.144 \\
(2.222)\end{array}$ & $\begin{array}{c}0.144 \\
(1.825)\end{array}$ & $\begin{array}{l}-0.668 \\
(0.810)\end{array}$ \\
\hline Party: PMDB (\%) & 8.54 & $\begin{array}{c}0.400 \\
\{3,275\}\end{array}$ & $\begin{array}{c}6.34^{* * *} \\
(2.08)\end{array}$ & $\begin{array}{c}1.56 \\
(5.55)\end{array}$ & $\begin{array}{c}1.90 \\
(4.11)\end{array}$ & $\begin{array}{c}3.04 \\
(2.97)\end{array}$ \\
\hline Party: PSDB (\%) & 8.99 & $\begin{array}{c}0.400 \\
\{3,275\}\end{array}$ & $\begin{array}{c}2.30 \\
(2.50)\end{array}$ & $\begin{array}{c}-8.34^{* * *} \\
(2.41)\end{array}$ & $\begin{array}{c}-8.67^{* * *} \\
(2.35)\end{array}$ & $\begin{array}{l}-3.34^{*} \\
(1.71)\end{array}$ \\
\hline Party: PT (\%) & 11.17 & $\begin{array}{c}0.400 \\
\{3,275\}\end{array}$ & $\begin{array}{c}8.23^{* * *} \\
(2.57)\end{array}$ & $\begin{array}{l}-4.76 \\
(6.52)\end{array}$ & $\begin{array}{c}1.54 \\
(3.73)\end{array}$ & $\begin{array}{c}0.50 \\
(3.00)\end{array}$ \\
\hline Number of Seats & 52.50 & $\begin{array}{c}0.313 \\
\{2,415\}\end{array}$ & $\begin{array}{c}-3.792^{* * * *} \\
(1.233)\end{array}$ & $\begin{array}{c}1.617 \\
(1.111)\end{array}$ & $\begin{array}{l}-2.046 \\
(1.333)\end{array}$ & $\begin{array}{c}-0.322 \\
(1.435)\end{array}$ \\
\hline $\begin{array}{l}\text { Number of Candidates } \\
\text { in the Coalition }\end{array}$ & 54.96 & $\begin{array}{c}0.258 \\
\{1,850\}\end{array}$ & $\begin{array}{c}3.456^{* * *} \\
(1.181)\end{array}$ & $\begin{array}{l}-0.810 \\
(2.711)\end{array}$ & $\begin{array}{l}4.559^{* *} \\
(2.077)\end{array}$ & $\begin{array}{c}5.316^{* * *} \\
(1.217)\end{array}$ \\
\hline $\begin{array}{l}\text { Number of Candidates } \\
\text { in the Electoral Unit }\end{array}$ & 589.6 & $\begin{array}{c}0.321 \\
\{2,499\}\end{array}$ & $\begin{array}{c}-76.63^{* * *} \\
(26.81)\end{array}$ & $\begin{array}{l}46.45^{* *} \\
(17.77)\end{array}$ & $\begin{array}{l}-34.59 \\
(29.20)\end{array}$ & $\begin{array}{l}-41.45 \\
(26.14)\end{array}$ \\
\hline Bandwidth & & & & $0.05 \%$ & $0.1 \%$ & $0.2 \%$ \\
\hline Observations & & & & 284 & 555 & 1,341 \\
\hline
\end{tabular}

All notes to Table 1.9 apply. 
Table 1.C6: Incumbency Effects on Candidacy and Winning - Federal Deputy, with Controls

\begin{tabular}{|c|c|c|c|c|c|}
\hline & $\begin{array}{c}\text { IKBW } \\
\{\text { obs }\}\end{array}$ & (1) & (2) & (3) & (4) \\
\hline \multicolumn{6}{|l|}{ Panel $A$} \\
\hline Candidacy $\mathrm{w} /$ in 4 years $(\%)$ & $\begin{array}{c}0.231 \\
\{1,595\}\end{array}$ & $\begin{array}{c}4.91 \\
(3.52)\end{array}$ & $\begin{array}{l}1.76 \\
(4.24)\end{array}$ & $\begin{array}{l}4.79^{*} \\
(2.46)\end{array}$ & $\begin{array}{c}2.07 \\
(4.31)\end{array}$ \\
\hline Winning w/in 4 years $(\%)$ & $\begin{array}{c}0.248 \\
\{1,749\}\end{array}$ & $\begin{array}{c}16.37^{* *} \\
(6.32)\end{array}$ & $\begin{array}{c}3.80 \\
(11.43)\end{array}$ & $\begin{array}{l}13.74 \\
(8.16)\end{array}$ & $\begin{array}{l}14.62^{*} \\
(8.28)\end{array}$ \\
\hline \multicolumn{6}{|l|}{ Panel B } \\
\hline $\begin{array}{l}\text { Candidacy for the same } \\
\text { pos. w/in } 4 \text { years }(\%)\end{array}$ & $\begin{array}{c}0.194 \\
\{1,283\}\end{array}$ & $\begin{array}{c}12.56^{* *} \\
(5.83)\end{array}$ & $\begin{array}{c}3.04 \\
(5.40)\end{array}$ & $\begin{array}{c}5.01 \\
(6.32)\end{array}$ & $\begin{array}{c}12.54^{* *} \\
(5.62)\end{array}$ \\
\hline $\begin{array}{l}\text { Winning the same } \\
\text { pos. w/in } 4 \text { years }(\%)\end{array}$ & $\begin{array}{c}0.262 \\
\{1,890\}\end{array}$ & $\begin{array}{c}28.56^{* * *} \\
(4.08)\end{array}$ & $\begin{array}{l}15.78 \\
(9.54)\end{array}$ & $\begin{array}{c}17.74^{* *} \\
(6.63)\end{array}$ & $\begin{array}{c}25.46^{* * *} \\
(5.71)\end{array}$ \\
\hline $\begin{array}{l}\text { Candidacy for another } \\
\text { pos. w/in } 4 \text { years }(\%)\end{array}$ & $\begin{array}{c}0.400 \\
\{3,275\}\end{array}$ & $\begin{array}{c}-29.40^{* * *} \\
(4.23)\end{array}$ & $\begin{array}{c}-21.15^{* * *} \\
(6.20)\end{array}$ & $\begin{array}{c}-18.30 * * * \\
(5.56)\end{array}$ & $\begin{array}{c}-23.23^{* * *} \\
\quad(6.29)\end{array}$ \\
\hline $\begin{array}{l}\text { Winning another } \\
\text { pos. w/in } 4 \text { years }(\%)\end{array}$ & $\begin{array}{c}0.360 \\
\{2,857\}\end{array}$ & $\begin{array}{c}-13.52^{* * *} \\
(2.14)\end{array}$ & $\begin{array}{c}-12.96^{* *} \\
(4.72)\end{array}$ & $\begin{array}{l}-5.57 \\
(5.38)\end{array}$ & $\begin{array}{c}-12.07^{* *} \\
(5.01)\end{array}$ \\
\hline Bandwidth & & IKBW & $0.05 \%$ & $0.1 \%$ & $0.2 \%$ \\
\hline Observations & & - & 284 & 555 & 1,341 \\
\hline
\end{tabular}

All notes to Table 1.9 apply. 
Table 1.C7: City Councilor - Incumbency Effects on Candidacy/Victory at Other Positions

\begin{tabular}{|c|c|c|c|c|c|c|}
\hline & $\begin{array}{l}\text { Loser } \\
\text { Mean }\end{array}$ & $\begin{array}{l}\text { IKBW } \\
\{\text { obs }\}\end{array}$ & $(1)$ & $(2)$ & $(3)$ & $(4)$ \\
\hline $\begin{array}{l}\text { Candidacy for mayor } \\
\text { within } 4 \text { years }(\%)\end{array}$ & 0.73 & $\begin{array}{c}0.400 \\
\{96,054\}\end{array}$ & $\begin{array}{c}0.45^{* * *} \\
(0.13)\end{array}$ & $\begin{array}{c}0.45 \\
(0.48)\end{array}$ & $\begin{array}{l}0.52^{*} \\
(0.29)\end{array}$ & $\begin{array}{c}0.48^{* *} \\
(0.20)\end{array}$ \\
\hline $\begin{array}{l}\text { Winning as mayor } \\
\text { within } 4 \text { years }(\%)\end{array}$ & 0.14 & $\begin{array}{c}0.374 \\
\{89,074\}\end{array}$ & $\begin{array}{l}-0.02 \\
(0.05)\end{array}$ & $\begin{array}{l}-0.07 \\
(0.14)\end{array}$ & $\begin{array}{l}-0.06 \\
(0.09)\end{array}$ & $\begin{array}{l}-0.03 \\
(0.07)\end{array}$ \\
\hline $\begin{array}{l}\text { Candidacy for state } \\
\text { deputy w/in } 4 \text { years }(\%)\end{array}$ & 2.16 & $\begin{array}{c}0.290 \\
\{67,044\}\end{array}$ & $\begin{array}{c}1.53 * * * \\
(0.49)\end{array}$ & $\begin{array}{l}2.67 * * \\
(1.12)\end{array}$ & $\begin{array}{c}1.82^{* * *} \\
(0.69)\end{array}$ & $\begin{array}{c}1.63^{* * *} \\
(0.47)\end{array}$ \\
\hline $\begin{array}{l}\text { Winning as state } \\
\text { deputy } \mathrm{w} / \text { in } 4 \text { years }(\%)\end{array}$ & 0.19 & $\begin{array}{c}0.249 \\
\{56,710\}\end{array}$ & $\begin{array}{l}-0.10^{*} \\
(0.06)\end{array}$ & $\begin{array}{l}-0.27 \\
(0.17)\end{array}$ & $\begin{array}{r}-0.21^{*} \\
(0.11)\end{array}$ & $\begin{array}{l}-0.09 \\
(0.07)\end{array}$ \\
\hline $\begin{array}{l}\text { Candidacy for federal } \\
\text { deputy w/in } 4 \text { years }(\%)\end{array}$ & 0.75 & $\begin{array}{c}0.386 \\
\{92,174\}\end{array}$ & $\begin{array}{c}0.50 * * * \\
(0.16)\end{array}$ & $\begin{array}{c}1.49 * * * \\
(0.51)\end{array}$ & $\begin{array}{c}1.44^{* * *} \\
(0.33)\end{array}$ & $\begin{array}{c}0.69 * * * \\
(0.21)\end{array}$ \\
\hline $\begin{array}{l}\text { Winning as federal } \\
\text { deputy } \mathrm{w} / \text { in } 4 \text { years }(\%)\end{array}$ & 0.02 & $\begin{array}{c}0.290 \\
\{67,056\}\end{array}$ & $\begin{array}{c}0.06 \\
(0.04)\end{array}$ & $\begin{array}{l}-0.08 \\
(0.06)\end{array}$ & $\begin{array}{c}0.11^{* *} \\
(0.05)\end{array}$ & $\begin{array}{l}0.09^{*} \\
(0.04)\end{array}$ \\
\hline Bandwidth & & & IKBW & $0.05 \%$ & $0.1 \%$ & $0.2 \%$ \\
\hline Observations & & & - & 9,738 & 20,949 & 44,546 \\
\hline
\end{tabular}

All notes to Table 1.9 apply. 
Table 1.C8: First-Term Mayor - Incumbency Effects on Candidacy/Victory at Other Positions

\begin{tabular}{|c|c|c|c|c|c|c|}
\hline & $\begin{array}{l}\text { Loser } \\
\text { Mean }\end{array}$ & $\begin{array}{c}\text { IKBW } \\
\{\mathrm{obs}\}\end{array}$ & (1) & $(2)$ & (3) & (4) \\
\hline $\begin{array}{l}\text { Candidacy for city } \\
\text { councilor w/in } 4 \text { years }(\%)\end{array}$ & 4.78 & $\begin{array}{c}1.350 \\
\{1,099\}\end{array}$ & $\begin{array}{l}-4.19^{*} \\
(2.18)\end{array}$ & $\begin{array}{c}-6.42^{* *} \\
(2.60)\end{array}$ & $\begin{array}{c}-4.42^{* * *} \\
(1.03)\end{array}$ & $\begin{array}{c}-4.75^{* * *} \\
(0.70)\end{array}$ \\
\hline $\begin{array}{l}\text { Winning as city } \\
\text { councilor w/in } 4 \text { years }(\%)\end{array}$ & 2.84 & $\begin{array}{c}1.270 \\
\{1,036\}\end{array}$ & $\begin{array}{l}-2.84^{*} \\
(1.50)\end{array}$ & $\begin{array}{c}-3.19^{*} \\
(1.67)\end{array}$ & $\begin{array}{c}-1.87^{* *} \\
(0.73)\end{array}$ & $\begin{array}{c}-2.66^{* * *} \\
(0.51)\end{array}$ \\
\hline $\begin{array}{l}\text { Candidacy for state } \\
\text { deputy w/in } 4 \text { years }(\%)\end{array}$ & 3.38 & $\begin{array}{l}0.895 \\
\{766\}\end{array}$ & $\begin{array}{l}-3.80^{*} \\
(2.07)\end{array}$ & $\begin{array}{l}-3.34^{*} \\
(1.95)\end{array}$ & $\begin{array}{c}-3.93^{* * *} \\
(0.86)\end{array}$ & $\begin{array}{c}-3.86^{* * *} \\
(0.64)\end{array}$ \\
\hline $\begin{array}{l}\text { Winning as state } \\
\text { deputy } \mathrm{w} / \text { in } 4 \text { years }(\%)\end{array}$ & 1.86 & $\begin{array}{l}1.106 \\
\{912\}\end{array}$ & $\begin{array}{l}-1.86^{*} \\
(0.97)\end{array}$ & $\begin{array}{r}-1.77^{*} \\
(0.99)\end{array}$ & $\begin{array}{c}-1.33 * * * \\
(0.46)\end{array}$ & $\begin{array}{c}-1.28^{* * *} \\
(0.33)\end{array}$ \\
\hline $\begin{array}{l}\text { Candidacy for federal } \\
\text { deputy w/in } 4 \text { years }(\%)\end{array}$ & -0.02 & $\begin{array}{l}0.891 \\
\{763\}\end{array}$ & $\begin{array}{c}0.02 \\
(0.06)\end{array}$ & $\begin{array}{l}-0.18 \\
(0.14)\end{array}$ & $\begin{array}{l}-0.07 \\
(0.34)\end{array}$ & $\begin{array}{l}-0.45^{*} \\
(0.26)\end{array}$ \\
\hline $\begin{array}{l}\text { Winning as federal } \\
\text { deputy w/in } 4 \text { years }(\%)\end{array}$ & 0.00 & $\begin{array}{l}0.662 \\
\{547\}\end{array}$ & $\begin{array}{c}0.00 \\
(0.00)\end{array}$ & $\begin{array}{c}0.00 \\
(0.00)\end{array}$ & $\begin{array}{c}-0.01 \\
(0.16)\end{array}$ & $\begin{array}{l}-0.14 \\
(0.14)\end{array}$ \\
\hline $\begin{array}{l}\text { Bandwidth } \\
\text { Observations }\end{array}$ & & & IKBW & $\begin{array}{l}1 \% \\
838\end{array}$ & $\begin{array}{c}5 \% \\
4293\end{array}$ & $\begin{array}{l}10 \% \\
8.013\end{array}$ \\
\hline
\end{tabular}

All notes to Table 1.10 apply. 
Table 1.C9: State Deputy - Incumbency Effects on Candidacy/Victory at Other Positions

\begin{tabular}{|c|c|c|c|c|c|c|}
\hline & $\begin{array}{l}\text { Loser } \\
\text { Mean }\end{array}$ & $\begin{array}{c}\text { IKBW } \\
\{\text { obs }\}\end{array}$ & $(1)$ & $(2)$ & $(3)$ & (4) \\
\hline $\begin{array}{l}\text { Candidacy for city } \\
\text { councilor w/in } 4 \text { years }(\%)\end{array}$ & 17.71 & $\begin{array}{c}0.170 \\
\{5,209\}\end{array}$ & $\begin{array}{c}-17.13^{* * *} \\
(4.56)\end{array}$ & $\begin{array}{c}-8.09 * * * \\
(2.17)\end{array}$ & $\begin{array}{c}-15.75^{* * *} \\
(4.12)\end{array}$ & $\begin{array}{c}-19.07 * * * \\
(4.77)\end{array}$ \\
\hline $\begin{array}{l}\text { Winning as city } \\
\text { councilor w/in } 4 \text { years }(\%)\end{array}$ & 14.04 & $\begin{array}{c}0.256 \\
\{9,922\}\end{array}$ & $\begin{array}{c}-14.78^{* * *} \\
(1.95)\end{array}$ & $\begin{array}{l}-7.29^{*} \\
(3.62)\end{array}$ & $\begin{array}{c}-10.93^{* * *} \\
(2.05)\end{array}$ & $\begin{array}{c}-12.60 * * * \\
(2.32)\end{array}$ \\
\hline $\begin{array}{l}\text { Candidacy for mayor } \\
\text { within } 4 \text { years }(\%)\end{array}$ & 21.34 & $\begin{array}{c}0.240 \\
\{8,913\}\end{array}$ & $\begin{array}{c}-5.06^{* * *} \\
(1.79)\end{array}$ & $\begin{array}{l}-5.91^{*} \\
(3.23)\end{array}$ & $\begin{array}{l}-3.99 \\
(2.68)\end{array}$ & $\begin{array}{c}-5.04^{* *} \\
(2.05)\end{array}$ \\
\hline $\begin{array}{l}\text { Winning as mayor } \\
\text { within } 4 \text { years }(\%)\end{array}$ & 9.02 & $\begin{array}{c}0.184 \\
\{5,873\}\end{array}$ & $\begin{array}{c}-6.42^{* * *} \\
(1.21)\end{array}$ & $\begin{array}{c}-6.11^{* * * *} \\
(1.68)\end{array}$ & $\begin{array}{c}-4.61^{* * *} \\
(1.51)\end{array}$ & $\begin{array}{c}-6.59 * * * \\
(1.21)\end{array}$ \\
\hline $\begin{array}{l}\text { Candidacy for federal } \\
\text { deputy w/in } 4 \text { years }(\%)\end{array}$ & 6.07 & $\begin{array}{c}0.400 \\
\{17,506\}\end{array}$ & $\begin{array}{c}0.34 \\
(0.86)\end{array}$ & $\begin{array}{c}8.06 * * * \\
(2.33)\end{array}$ & $\begin{array}{l}3.21^{*} \\
(1.81)\end{array}$ & $\begin{array}{l}-0.03 \\
(1.76)\end{array}$ \\
\hline $\begin{array}{l}\text { Winning as federal } \\
\text { deputy } \mathrm{w} / \text { in } 4 \text { years }(\%)\end{array}$ & 0.67 & $\begin{array}{c}0.287 \\
\{11,626\}\end{array}$ & $\begin{array}{c}1.47^{* * *} \\
(0.46)\end{array}$ & $\begin{array}{l}1.80 \\
(1.61)\end{array}$ & $\begin{array}{c}1.56 \\
(1.23)\end{array}$ & $\begin{array}{l}1.20 \\
(0.74)\end{array}$ \\
\hline Bandwidth & & & IKBW & $0.05 \%$ & $0.1 \%$ & $0.2 \%$ \\
\hline Observations & & & - & 1,357 & 2,763 & 6,665 \\
\hline
\end{tabular}

All notes to Table 1.9 apply. 
Table 1.C10: Federal Deputy - Incumbency Effects on Candidacy/Victory at Other Positions

\begin{tabular}{|c|c|c|c|c|c|c|}
\hline & $\begin{array}{l}\text { Loser } \\
\text { Mean }\end{array}$ & $\begin{array}{c}\text { IKBW } \\
\{\mathrm{obs}\}\end{array}$ & (1) & $(2)$ & $(3)$ & (4) \\
\hline $\begin{array}{l}\text { Candidacy for city } \\
\text { councilor w/in } 4 \text { years }(\%)\end{array}$ & 19.85 & $\begin{array}{c}0.331 \\
\{2,634\}\end{array}$ & $\begin{array}{c}-19.41^{* * *} \\
(5.21)\end{array}$ & $\begin{array}{l}-7.03 \\
(5.03)\end{array}$ & $\begin{array}{c}-10.18^{* *} \\
(4.17)\end{array}$ & $\begin{array}{c}-12.73^{* *} \\
(5.63)\end{array}$ \\
\hline $\begin{array}{l}\text { Winning as city } \\
\text { councilor w/in } 4 \text { years }(\%)\end{array}$ & 11.35 & $\begin{array}{c}0.400 \\
\{3,275\}\end{array}$ & $\begin{array}{c}-11.35^{* * *} \\
(2.19)\end{array}$ & $\begin{array}{c}-10.70^{*} \\
(5.88)\end{array}$ & $\begin{array}{c}-6.59^{* *} \\
(2.59)\end{array}$ & $\begin{array}{c}-10.32^{* *} \\
(3.77)\end{array}$ \\
\hline $\begin{array}{l}\text { Candidacy for mayor } \\
\text { within } 4 \text { years }(\%)\end{array}$ & 22.53 & $\begin{array}{c}0.296 \\
\{2,287\}\end{array}$ & $\begin{array}{c}-7.00^{* * *} \\
(2.18)\end{array}$ & $\begin{array}{l}-7.61 \\
(9.67)\end{array}$ & $\begin{array}{l}-5.30 \\
(6.74)\end{array}$ & $\begin{array}{l}-5.71 \\
(4.34)\end{array}$ \\
\hline $\begin{array}{l}\text { Winning as mayor } \\
\text { within } 4 \text { years }(\%)\end{array}$ & 4.87 & $\begin{array}{c}0.400 \\
\{3,275\}\end{array}$ & $\begin{array}{l}-0.13 \\
(1.69)\end{array}$ & $\begin{array}{c}0.39 \\
(5.03)\end{array}$ & $\begin{array}{l}1.90 \\
(3.92)\end{array}$ & $\begin{array}{l}-0.92 \\
(2.54)\end{array}$ \\
\hline $\begin{array}{l}\text { Candidacy for state } \\
\text { deputy w/in } 4 \text { years }(\%)\end{array}$ & 11.02 & $\begin{array}{c}0.400 \\
\{3,275\}\end{array}$ & $\begin{array}{c}-7.17^{* * *} \\
(1.37)\end{array}$ & $\begin{array}{c}0.12 \\
(3.31)\end{array}$ & $\begin{array}{l}-2.62 \\
(2.19)\end{array}$ & $\begin{array}{c}-6.16^{* * *} \\
(2.14)\end{array}$ \\
\hline $\begin{array}{l}\text { Winning as state } \\
\text { deputy } \mathrm{w} / \text { in } 4 \text { years }(\%)\end{array}$ & 1.72 & $\begin{array}{c}0.400 \\
\{3,275\}\end{array}$ & $\begin{array}{c}-0.75 \\
(0.81)\end{array}$ & $\begin{array}{c}-0.31 \\
(1.42)\end{array}$ & $\begin{array}{c}0.07 \\
(1.27)\end{array}$ & $\begin{array}{c}-1.19 * \\
(0.60)\end{array}$ \\
\hline Bandwidth & & & IKBW & $0.05 \%$ & $0.1 \%$ & $0.2 \%$ \\
\hline Observations & & & - & 284 & 555 & 1,341 \\
\hline
\end{tabular}

All notes to Table 1.9 apply. 


\section{Party Affiliation and Clientelism: Evidence from Brazil}

\section{$2.1 \quad$ Introduction}

A large body of literature in both economics and political science extensively documents the notion that developing countries are frequently plagued by political clientelism - the strategic distribution of benefits by political parties and governments to disadvantaged groups in exchange for electoral support-, which undermines their democracies' wellfunctioning and economic development. ${ }^{1}$ The pervasiveness of such political distortion occurs despite a key enforcement problem underlying this vote-buying party-voter linkage in electoral contests with a secret ballot, namely that voters may not want to vote for the corresponding candidates once they have received their benefits. This puzzle has led several authors to suggest a variety of different actions taken by politicians to overcome the problem of identifying which voters voted for them, such as monitoring vote counts in specific jurisdictions (Larreguy (2013), Stokes (2005)) and opting for selective and reversible methods of redistribution (e.g. public sector employment) in order to tie voters' utilities to the candidate's electoral success (Robinson and Verdier (2013)).

The goal of this chapter is to investigate empirically whether - and in what circumstancesparty affiliation ${ }^{2}$ by voters may be used by politicians as an alternative instrument for promoting an incentive-compatible setting regarding clientelistic practices among voters. The basic idea is that as it constitutes an instance of public demonstration of support for a given party, an affiliated voter is unlikely to be offered any rewards by other parties and may even be punished if those other parties should win. In effect, inasmuch as information on party affiliation by voters may be open access information - as in the case we study - it is arguably a more effective way of publicly displaying allegiance to a party than more traditional options reported and explored by the related literature, such as wearing badges and party colors or attending political rallies (Kitschelt and Wilkinson (2007)). Moreover, affiliation possibly increases voters' chances of reward if their party

\footnotetext{
${ }^{1}$ Kitschelt and Wilkinson (2007) highlight the prominence and features of clientelism in institutional descriptions of developing countries and in historical accounts of currently developed countries such as Japan and the U.S. Also see Hicken (2011) for a comprehensive survey of the recent work on clientelism.

${ }^{2}$ The word "affiliation" is used here in the sense of actual membership of a political party and not in the looser sense of merely supporting the party in a general way.
} 
is elected, as it grants them participation in the party's decision-making process over policies and electoral issues, as well as over the appointment of affiliated members to positions in the party's administrative body. Put together, these elements suggest that any clientelistic efforts exerted by parties would be especially effective when focused on inducing voter affiliation or when targeted at already affiliated voters. As such, our work contributes to the literature on political clientelism by providing an investigation into a political institution - that of affiliation to a political party - through which clientelistic practices may be sustained. Despite the fact that party affiliation constitutes a typical feature of political systems worldwide, the connection between affiliation and clientelism (to the best of our knowledge) appears to have been unexplored by the related literature.

In this chapter, we use the Brazilian local political context to assess empirically two major questions regarding party affiliation by voters and its connection to clientelism. First, we explore the more central issue of whether clientelistic practices are carried out by local governments based on voters' affiliation status. Specifically, we investigate whether winning parties in local elections especially target voters previously affiliated to them (as a reward for their fidelity) with the provision of payments from the Bolsa Familia, Brazil's largest conditional cash transfer program and one of the largest in the world. The Bolsa Familia currently covers over 14 million families and costs about $0.4 \%$ of the country's GDP. Despite being federally funded, local governments are responsible for the identification and registration of eligible families. While evidence has been found that the program has had a positive and substantial impact on schooling outcomes and on inequality (Soares and Sátyro (2009), Glewwe and Kassouf (2012)), both the press and public auditing agencies have reported several instances of irregularities in the distribution of benefits. ${ }^{3}$

Estimating a causal effect of partisan incumbency on such clientelistic targeting of benefits may plausibly lead to biased results since the electoral performance of a given party is likely correlated with the political orientation of voters and the levels of affiliation to each party. Moreover, it is possible that the ability (and willingness) to target benefits in such a way greatly varies across incumbent parties, as operation of the program at the federal level has been conducted solely by the Workers' Party (PT) since the program's implementation in 2003. For the same reason, the program is largely regarded as exclusive to the PT and, as such, may be ineffective or even harmful to other parties that attempt to use it in a clientelistic fashion. Thus, we deal with these issues by relying on a regression discontinuity design based on local election outcomes, comparing municipalities in which the candidate from the PT local coalition won or lost by a small margin. ${ }^{4}$ In particular,

\footnotetext{
${ }^{3}$ Further details on this matter are presented in the next section.

${ }^{4}$ In Brazilian local elections parties may form coalitions, but only one candidate per coalition may run for mayor in a given municipality. The decision to consider parties in the PT coalition instead of
} 
this approach enables us to control for unobserved characteristics of the municipality that are correlated with parties' electoral performances and with voter affiliation. Our results indicate that voters affiliated to a party in the PT municipal coalition are much more likely to start receiving Bolsa Familia benefits upon election of a mayoral candidate from that coalition; however, the estimated effects are statistically significant only for municipalities with relatively small populations. At the same time, we also observe that incumbency by a party in the PT coalition is not associated with an increase in the probability that voters affiliated to other parties start receiving the corresponding benefits, which reinforces our interpretation of affiliation-based clientelism.

In light of these findings, we turn to the second question of exploring the potential presented by certain factors under the direct control of locally elected parties and candidates in motivating voter affiliation. Given that such affiliation may assist parties in (subsequently) determining who to target in relation to vote-buying (thus impacting the extent of clientelism), it is worthwhile to assess what drives voter affiliation even if the decision to become affiliated were entirely based on reasons without a clientelistic nature. In this sense, we begin by investigating whether local incumbency by a given political party has, by itself, a causal effect of (locally) raising affiliation to that party. As in the first part of our analysis, estimating such a causal impact is clearly rendered difficult by the fact that a party is more likely to be elected in regions where affiliation to it is relatively higher. In order to circumvent this problem, we once again exploit quasi-experimental variation generated by the electoral system through a regression discontinuity analysis. For three of the parties with the largest numbers of affiliated voters in Brazil, we compare municipalities in which the party narrowly lost or narrowly won mayoral elections. Our estimates suggest that while local incumbency may greatly affect voter affiliation in particular conditions, this influence is far from generalized as statistically significant estimates are more robustly found only for one party and for a specific subsample of municipalities (the ones with lower literacy levels).

The second half of our analysis is then complemented by exploring whether voter affiliation may be induced by local governments through the discretionary provision of payments from the Bolsa Familia. The private character of those transfers coupled with the ability of local governments to define beneficiary families may constitute an even more effective instrument in motivating affiliation than merely holding office. We estimate the contemporaneous impact of receiving Bolsa Familia payments on party affiliation by making use of yearly data on all Brazilian municipalities regarding the proportion of families covered by the program, the share of the municipal population affiliated to a political party, and other municipal characteristics. A plausible concern in this setting would be the existence

dealing with distinct parties separately is made for the purpose of gaining statistical power. 
of unobserved characteristics likely correlated with both Bolsa Familia coverage and the extent of party affiliation in the municipality. The share of people receiving benefits from the program, for instance, is closely related to the incidence of poverty, which is arguably associated with lower levels of education and, in turn, to a lower level of political participation. To overcome these endogeneity issues, we exploit an expansion of the program in an instrumental variables approach. In 2008, the Bolsa Familia was expanded in order to take into account the number of adolescents aged 16 and 17 in the calculation of payments for each family-before that, only the number of students aged 15 or below was considered. Hence, by combining the timing of the expansion with the demographic composition of municipalities, we are able to construct an instrument that allows us to estimate a causal impact of the Bolsa Familia on party affiliation. Our results are suggestive of a positive, robust, and highly significant effect. We note that while this finding alone does not indicate that new affiliations resulting from Bolsa Familia payments are purposely configured according to clientelistic arrangements, it nonetheless suggests that making program payments conditional on affiliation may serve as an effective strategy to be implemented by politicians who eventually become interested in vote-buying.

Our work is closely related to the literature on clientelism and clientelistic networks. Kitschelt and Wilkinson (2007) eloquently describe the abovementioned problem of enforcement and the solutions employed by parties for circumventing it in several contexts. Bardhan and Mookherjee (2012) provide a model that contemplates the influence of both clientelism and elite capture on the allocation of public services and welfare, and generates empirical implications that help explain observed impacts of political reservations in India that are inconsistent with standard models of redistributive politics. Lizzeri and Persico (2001) discuss the trade-off between efficiency and voter targetability leading to the underprovision of public goods under different electoral systems, a result also argued by Robinson and Verdier (2013) and Keefer (2007). Evidence on the potential of clientelistic transactions to influence voting behavior is presented by Stokes (2005), who analyses the results of a survey conducted in Argentina. In addition, Finan and Schechter (2012) conduct a survey in Paraguay with the intermediaries responsible for brokering the clientelistic exchanges between voters and politicians. Their results suggest that politicians with a vote-buying purpose are more likely to target individuals with stronger feelings of intrinsic reciprocity.

Insofar as affiliation to a political party provides citizens with greater access to policyrelated information, our work is also related to the literature on political agency and electoral accountability. Ferejohn (1986), Persson and Tabellini (2002) and Besley (2006) study theoretical models in which information plays a crucial role in forcing incumbent governments to act in the best interest of the public. In these models, as well as in 
those presented by Grossman and Helpman (1996, 1999) and by Baron (1994), voters' information is a relevant factor in determining the extent to which special interest groups are capable of influencing policy outcomes. Moreover, Besley and Burgess (2002) provide empirical evidence suggesting that a more informed and politically active electorate strengthens incentives for governments to be responsive.

Lastly, this chapter contributes to the literature on the determinants and outcomes of political participation and party identification. Extensive research on the association between education and political participation has traditionally reported a strong and positive relationship (Hillygus (2005), Nie et al. (1996), Wolfinger and Rosenstone (1980)), although a more robust investigation of the corresponding causal link has only recently been developed and has led to mixed results: while Milligan et al. (2004) and Glaeser et al. (2007) find a positive association, Persson (2014) and Solis (2014) present evidence suggesting that education has no causal influence on political participation. Banfield (1967) uses the concept of "amoral familism" to argue that strong family ties lead to low civic engagement and low political participation, an idea later reinforced by the empirical findings by Alesina and Giuliano (2011). Gerber et al. (2010) present evidence from experimental data suggesting that the simple procedure of party affiliation by voters is capable of inducing stronger partisanship, and of bringing about changes in planned voting decisions and in political attitudes such as the perception of political events and the evaluation of political institutions. ${ }^{5}$ In turn, the existence of strong partisan ties has been considered by some authors as a foundation for political stability in democracies (Converse and Dupeux (1962), Converse (1969)). ${ }^{6}$

The remainder of the chapter is organized as follows. Section 2.2 provides some background information about party affiliation in Brazil. It also discusses the main features of the Bolsa Familia and reports qualitative evidence on corruption in the program's targeted payments. Section 2.3 describes the data, and Section 2.4 discusses the empirical strategies and presents our main results. Section 2.5 concludes the chapter.

\footnotetext{
${ }^{5}$ The role of party identification in shaping citizens' perceptions of, and interactions with, the political world are also explored by Bartels (2000, 2002), Campbell et al. (1960) and Gerber and Huber (2010).

${ }^{6}$ Also, see Guiso et al. (2004) for evidence on a positive effect of political participation (as a measure of social capital) on financial development.
} 


\section{$2.2 \quad$ Institutional Background}

\subsubsection{Party Affiliation in Brazil}

In early 2015, Brazil had more than 15 million voters affiliated to 32 political parties, accounting for more than $7.5 \%$ of its estimated population. ${ }^{7}$ Figure 2.1 below depicts the heterogeneity in the share of affiliated voters across Brazilian municipalities.

Figure 2.1: Share of Voters Affiliated to a Political Party in 2010 (\%), by Municipality

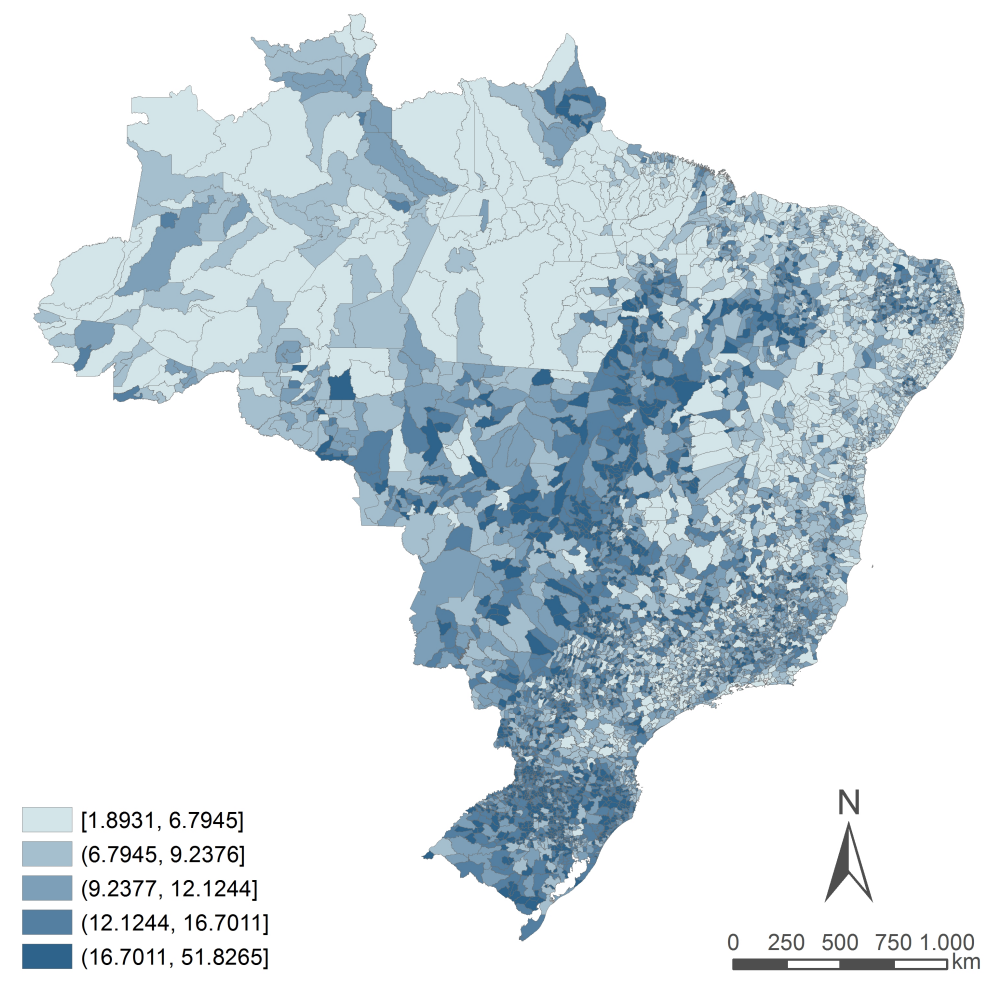

Brazilian legislation dictates that only voters in full possession of their political rights are allowed to affiliate to a political party. In essence, political rights may be lost in the event of loss of Brazilian nationality or annulment of naturalization. These rights may also be suspended in cases of absolute civil inability (e.g. citizens younger than 16 or diagnosed as psychopaths), criminal conviction, refusal to observe generally imposed legal obligations (e.g. military service, for males), and administrative improbity. Moreover, the Constitution prohibits party affiliation by government-related groups like magistrates and active members of the armed forces.

Affiliation to a political party, in its turn, is a necessary condition for eligibility to run for office. While the electoral law establishes that a candidate must in general have been

\footnotetext{
${ }^{7}$ Source: http://www.tse.jus.br/eleitor/estatisticas-de-eleitorado/filiados. Accessed on 02/17/2015.
} 
affiliated to the corresponding party for at least one year at the time of election, political parties may require even longer periods of affiliation as a condition of candidacy. ${ }^{8}$ Parties' bylaws are also required to describe the rights and duties of their members (e.g. diligently participating in the political campaigns of the party's candidates, spreading the party's vision), and may require them to make financial contributions for the maintenance of party activities.

Regarding the party affiliation process, a registered voter is considered affiliated to a party after formally expressing a commitment to comply with the party's principles and bylaws, and having his request evaluated and accepted by a designated executive commission of the party's administrative body. ${ }^{9}$ Twice a year, in the months of April and October, each political party must send a list of all their affiliated members - and corresponding affiliation dates - to electoral authorities for filing and publication purposes, as well as for the observance of the affiliation term requirement for candidates. ${ }^{10}$ Up to 2013, voters affiliated to more than one political party at the same time would have both registrations canceled; since then, however, electoral law dictates that the most recent registration be maintained and the others canceled.

Once voters become affiliated, they are granted fairly broad participation in several aspects of the party's activities and decisions over its own internal functioning and policy stances. By attending party meetings and political conventions, affiliated members are able to vote on matters such as the definition of the party's coalitions and expenditure limits for electoral campaigns, and may also call for internal referendums and request political information. Furthermore, party affiliates may vote for and be elected as pledged delegates or be appointed to positions at various levels of the party's administrative body.

\subsubsection{The Bolsa Família CCT Program}

Bolsa Familia is Brazil's prime federal CCT program and stands among the largest programs of that kind in the world. It was created in 2003 by then President Luiz Inácio Lula da Silva, from the Workers' Party (PT), and consisted primarily of the consolidation and gradual expansion of several pre-existent social support programs (Bolsa Escola, Bolsa Alimentação, Programa de Erradicação do Trabalho Infantil, Vale Gás), which were man-

\footnotetext{
${ }^{8}$ Some exceptions are former magistrates and members of the armed forces, who need only have been affiliated for six months.

${ }^{9}$ New requests for affiliation may also be disputed by ordinary party affiliates for a predetermined period.

${ }^{10}$ In Brazil, the first round of elections is held on the first Sunday of October. Thus, the delivery of lists of affiliated voters in these months allows electoral authorities to assess whether candidates satisfy the six-month and twelve-month requirements for minimal affiliation terms.
} 
aged rather inefficiently due to only minimal coordination. ${ }^{11}$ Since then, the program has served as the cornerstone of the PT's electoral campaigns. ${ }^{12}$

The Bolsa Familia program provides different types of benefits according to family income and composition, and imposes various conditionalities. To qualify for it, a family must have a monthly per capita income below $\mathrm{R} \$ 140$, which is less than $25 \%$ of Brazil's minimum wage. Families with a monthly per capita income below $\mathrm{R} \$ 70$ - classified as "extremely poor" - are eligible to receive a payment (Basic Benefit) of $\mathrm{R} \$ 70$ regardless of their demographic composition. In addition, families with a monthly per capita income from $\mathrm{R} \$ 70$ to $\mathrm{R} \$ 140$ - classified as "poor" - are eligible to receive the Variable Benefits if they have a pregnant or breastfeeding woman or children under the age of 15 . These families receive monthly payments of $\mathrm{R} \$ 32$ per beneficiary (children under 15 or a pregnant/breastfeeding woman) up to a maximum of five payments per month. Payments for pregnant and breastfeeding women, however, are provided only for nine and six months, respectively. Finally, the creation of the Variable Youth Benefit in 2008 extended these benefits to include adolescents aged between 16 and 17 . This benefit provided monthly payments of $\mathrm{R} \$ 38$ per adolescent in that age group up to a maximum of two payments per month. ${ }^{13}$

Thus, the maximum amount a family may receive from these benefits in a single month is $R \$ 306$, which is the case for families with a monthly per capita income below $R \$ 70$, five children under 15 (or four children under 15 and one pregnant/breastfeeding woman) and two adolescents aged between 16 and 17. For a family with seven members in that scenario, these transfers would amount to more than $60 \%$ of the total family income.

Bolsa Família also makes its transfers conditional on compliance with schooling and health conditionalities. Regarding schooling, each child aged between 6 and 15 must be enrolled in school and attend for at least $85 \%$ of school days each month. For adolescents between 16 and 17, attendance must be higher than 75\%. Health conditionalities, in turn, require observance of a vaccination calendar for children under 7 , health monitoring for women between 14 and 44, prenatal care for pregnant women, and health monitoring for breastfeeding women and their babies. The proportion of families dropped from the program due to non-compliance, however, is very low, as they may receive several warnings before the benefit is finally canceled. Also, it is frequently claimed that conditionalitiesespecially in health - are not strongly enforced.

\footnotetext{
${ }^{11}$ Soares and Sátyro $(2009)$ provide a detailed discussion of Bolsa Família's institutional design and implementation issues, as well as a brief review of the literature of its impacts along several dimensions.

${ }^{12}$ The Brazilian federal government has been under the control of the PT since 2003.

${ }^{13}$ The payment figures in this section refer to 2013. The exchange rate between the Brazilian Real and the US Dollar on January 2013 was $1.99 \mathrm{R} \$ / \mathrm{US} \$$.
} 
The program is operated by the federal and municipal governments. The municipal budget for Bolsa Família is set and funded by the federal government, based on estimates of the number of poor families according to the population census and to recent household surveys (PNAD). Municipal governments are responsible for identifying and registering eligible families, as well as for the monitoring of compliance with the program's conditionalities. Information on the registered families is then sent to Caixa Econômica Federal (the program's operating agent), and consolidated into a national registry database for social programs (Cadastro Único). At this point, beneficiary families are automatically selected according to criteria defined by the Ministry of Social Development (regarding their income and demographic composition) and depending on the available municipal budget. The Caixa also transfers the benefit amounts directly to individual family accounts and provides beneficiary families with Bolsa Familia bank cards for withdrawal of the payments.

\subsubsection{Evidence of Corruption from the Press and Audit Reports}

Despite the potential for higher accountability embedded in Bolsa Familia's decentralized operation, evidence of irregularities by the program's local managers regarding the targeting of benefits has frequently been identified both by the press and by public auditors. Public auditing of Bolsa Familia was enhanced by the creation of an anti-corruption program-Programa de Fiscalização a partir de Sorteios Públicos-by the federal government in 2003, consisting of the random auditing of local governments' expenditures. ${ }^{14}$ That program is conducted by the Controladoria-Geral da União (CGU) - the central body of the Federal Government Internal Control System - and aims at discouraging corruption among public administrators and fostering higher participation by civil society in the control of public expenditures.

Regarding the rounds of auditing conducted in 2012 and 2013, CGU reports have stated that around $98 \%$ of audited municipalities presented some sort of irregularity in the implementation of Bolsa Familia, the payment of benefits to families with a per capita income above the limit being identified as the most common occurrence of fraud. As some specific examples, it is reported that in the municipality of Cipó, Bahia, the mayor's daughter received the benefit despite having an income value above the ceiling. This was also the case for 43 government employees in Boca da Mata, Alagoas, where it was also found that retired (and, thus, ineligible) citizens were receiving benefits. In the municipality of Belford Roxo, Rio de Janeiro, CGU auditors found evidence that more

\footnotetext{
${ }^{14}$ The selection of audited municipalities is made through lotteries held by the Caixa Econômica Federal and may be witnessed by members of civil society.
} 
than 1,500 ineligible families were Bolsa Familia beneficiaries. Also, the reports state that in São José do Sul, Rio Grande do Sul, the wife of a rural worker who had an income of $\mathrm{R} \$ 955,000$ in 2009 was listed as a beneficiary. Other irregular practices reported by the auditors were that benefits were being paid to people who were deceased (e.g. in Xexéu, Pernambuco) and that children from beneficiary families were not even enrolled in school (e.g. in Jaguaribara, Ceará). Moreover, the reports describe cases in which beneficiaries claim not to have received Bolsa Família bank cards (e.g. in Lagoa Alegre, Piauí). ${ }^{15}$

Similar irregularities have also been found by different auditing agencies and by public prosecutors. Audits performed by the Tribunal de Contas da União (TCU) in 2009 found evidence of fraud in approximately 106,000 Bolsa Familia benefits, including payments for deceased citizens, elected politicians, and car owners. They also suggest that fixing these irregularities would reduce government expenditures by $\mathrm{R} \$ 318$ million per year. ${ }^{16}$ In the state of Minas Gerais, the prosecution office found that several thousand beneficiaries were affiliated to a political party, which led to an investigation on whether these benefits were politically motivated. The Ministry of Social Development itself formally instructed state prosecution offices to compare the lists of Bolsa Família beneficiaries to those of party affiliates in case irregularities in the program were identified. ${ }^{17}$

In addition, anecdotal evidence on corruption in Bolsa Familia has also been extensively provided by the press. In Tabira, Pernambuco, after several complaints from beneficiaries who were not receiving their payments, the local manager of the program was found in possession of 73 of the program's bank cards. A more striking example took place in the municipality of Barra do Quaraí, near the Brazil-Uruguay border, where the more traditional irregularities were accompanied by the fact that residents of Uruguay were registering for the program using fake addresses. The public prosecutor suggested that these irregularities were part of an electoral fraud: "Uruguayans receive Bolsa Familia (...) and, in return, register as voters. At the next election, they give their vote to whoever grants them this favor."18

\footnotetext{
${ }^{15}$ The aforementioned CGU reports are publicly available at the following website: http://sistemas.cgu.gov.br/relats/relatorios.php.

${ }^{16}$ The TCU is an independent and autonomous office that assists the National Congress in carrying out external audits on the executive branch of the Brazilian government.

${ }^{17}$ http://pfdc.pgr.mpf.mp.br/atuacao-e-conteudos-de-apoio/publicacoes/alimentacao-adequada/bolsa_familia.pdf.

${ }^{18}$ Author's translation.
} 


\section{$2.3 \quad$ Data}

In this chapter, we make use of data obtained from various sources. The Tribunal Superior Eleitoral (TSE) - the federal electoral authority - provides information on the party affiliation records of every voter who registered for affiliation (at least once) up to 2012, including the start and end dates of each affiliation, the affiliated voters' names, and the municipalities in which they are electorally registered. We then use these data to establish to which party each voter was affiliated in a given year and the corresponding municipal aggregates. We also employ electoral outcome variables from the TSE regarding the results for all mayoral elections from 1996 to 2012, which include vote totals for each candidate by municipality, the party affiliation of each candidate, and each municipality's electorate size. ${ }^{19}$ This information in turn is used for the construction of electoral performance measures such as vote shares and win margins, and of controls such as the number of candidates running for office, whether a candidate is running for reelection, and whether a candidate is affiliated to the same party as the corresponding state governor.

In addition, we use administrative data from 2008 to 2013 provided by the MDS on Bolsa Familia beneficiaries at the head of household level. In particular, these data contain monthly information on current beneficiaries by municipality — such as the beneficiaries' names and unique social identification numbers (NIS) - which we match to determine the beneficiaries who received payments at any point in a given year. Furthermore, for each municipality we match the list of beneficiaries' names to that of party-affiliated voters' names. ${ }^{20}$ By doing so, we can determine the number of voters affiliated to a given party who come to receive benefits in the following years. This information will perform a central role in our investigation of corruption in the operation of Bolsa Família. Also, data on the number of beneficiaries at the municipal level is available from the Instituto de Pesquisa Econômica Aplicada (IPEA) for the period between 2004 and 2012. ${ }^{21}$

In order to capture any underlying heterogeneity in municipal characteristics and to improve the precision of our estimates, we also rely on demographic control variables provided by the Instituto Brasileiro de Geografia e Estatistica and the IPEA, and constructed from the 1991, 2000, and 2010 population censuses, and from the 1996 and 2007 population counts. Some of these key variables include population size, share of urban

\footnotetext{
${ }^{19}$ Brazil has over 5,500 municipalities in its 26 states and the federal district. Brazilian elections happen every four years and voting is mandatory except for citizens aged below 18 or above 70 , and for illiterate people. State elections are held jointly with federal elections, and staggered by two years relative to municipal elections.

${ }^{20}$ This matching procedure is done by considering only individuals whose names are not duplicated in the same municipality.

${ }^{21}$ The IPEA is a government-led research institute dedicated to providing technical support and assisting policymaking.
} 
population, per capita income, territorial area, and the share of the population aged above 15 who is literate. For a given observation (year-municipality) in the sample under analysis, each variable assumes its most recent known value as provided by those sources.

\subsection{Empirical Strategies and Results}

\subsubsection{Targeting of Bolsa Família Payments to Affiliated Voters}

We begin our empirical analysis by exploring whether elected parties engage in clientelistic transactions based on voters' affiliation status as a reward for these voters' loyalty. Specifically, we are interested in estimating a causal effect of local government incumbency by specific parties on the incidence of corruption in the Bolsa Familia consisting of targeting benefits to voters who were previously affiliated to the recently elected parties. Since participation in the program is not a universal right for families who comply with the conditionalities, the responsibility of identifying and registering eligible beneficiaries endows local governments with the ability to target benefits to families at their own discretion. We focus on the effect of incumbency by the PT municipal coalition (i.e. by the party that ran under that coalition), as the PT has been responsible for the federal level management of the Bolsa Familia since 2003, when the program was created. A potential issue in producing unbiased estimates of such an effect comes from the fact that municipalities may vary greatly in terms of the political orientation of their citizens and socioeconomic characteristics. In that case, the existence of unobserved variables related to the probability of election of a given party and to the incidence of poverty or to Bolsa Familia coverage (especially among affiliated voters) is very likely to preclude any interpretation of the estimated correlation between incumbency and targeting of benefits to affiliated voters as a causal effect.

In order to bypass those issues, we rely on applying a regression discontinuity (RD) design to Brazilian municipal elections. This setup exploits the fact that while political agents may surely influence election results (e.g. through campaign activities and votebuying), they do not possess complete control over electoral outcomes. A random chance component of the vote share may be illustrated by, for instance, the weather on election day or the occurrence of traffic jams. Thus, inherent uncertainty in the final vote count is usually a plausible notion. ${ }^{22}$ Intuitively, such a random component would present a more important role in determining election results the smaller the vote share margin (i.e. the difference in vote share relative to the best adversary) of the elected candidate.

\footnotetext{
${ }^{22}$ Exceptions include cases of electoral fraud, for instance.
} 
In other words, letting $V_{m, t}$ be the vote share margin of the party running under the PT coalition at the mayoral election in year $t$ and municipality $m$, and letting $I_{m, t}$ denote treatment (in our case, incumbency) status of such party in $m$ following the election in year $t, I_{m, t}$ is considered as good as random in a local neighborhood of $V_{m, t}=0$. Naturally, incumbency status is completely determined by vote share margin: $I_{m, t}=1$ if $V_{m, t}>0$ and $I_{m, t}=0$ if $V_{m, t}<0$. As well established in the RD literature (e.g. Lee (2008)), the discontinuous nature of the (deterministic) relationship between treatment status and vote share margin coupled with continuity assumptions on the density of the vote share margin allows the estimation of causal incumbency effects at $V_{m, t}=0$. In this chapter, we estimate the quantities

$$
\tau=E\left[Y_{m, t}(1) \mid V_{m, t}=0\right]-E\left[Y_{m, t}(0) \mid V_{m, t}=0\right]
$$

where $Y_{m, t}(1)$ and $Y_{m, t}(0)$ generically denote an outcome of interest when the party running under the PT coalition in municipality $m$ and year $t$ is a winner and a loser of $m$ 's election for mayor, respectively.

Let new_bene $f_{m, t+1}$ and new_bene $f_{m, t+2}$ be the number of (head of household) individuals in municipality $m$ who start receiving Bolsa Familia payments in the first and in the second year respectively following municipal elections in $t$. Also, let PT_new_bene $f_{m, t+1}$ and PT_new_bene $f_{m, t+2}$ denote the number of (head of household) individuals in municipality $m$ who are affiliated (in election year $t$ ) to any party in the PT mayoral coalition in $t$ and who start receiving Bolsa Família payments in $t+1$ and $t+2$, respectively. Then, our outcomes of interest are given by

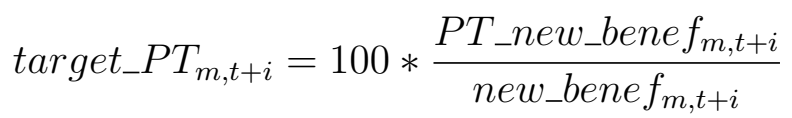

for $i=1,2$. In words, target_P $T_{m, t+i}$ represents the percentage of individuals who were affiliated to any party in $m$ 's PT coalition in election year $t$ among those who start receiving benefits in the $i$ th year following that election. In particular, the denominator in these expressions serves to account for the possibility that the amount of Bolsa Familia resources transferred by the federal government to municipalities is sensitive to the locally incumbent party.

Estimation of the treatment effects follows the guidelines in Imbens and Kalyanaraman (2012) and Imbens and Lemieux (2008), and is performed non-parametrically by local linear regression. This amounts to estimating regressions of each given outcome on $V_{m, t}$ for each side of the discontinuity by using only data satisfying $V_{m, t} \in[-h, 0)$ and $V_{m, t} \in(0, h]$, where $h$ is the bandwidth. Thus, we compare municipalities in which the PT coalition candidate lost or won only by a small margin. Also, a rectangular kernel is used in 
the estimation. In this case, our local linear regression estimates are equivalent to OLS estimates of the equation

$$
\text { target_PT } T_{m, t+i}=\alpha+\tau I_{m, t}+\beta_{0} V_{m, t}+\beta_{1} V_{m, t} I_{m, t}+\gamma^{\prime} \mathbf{X}_{\mathbf{m}, \mathbf{t}}+\theta_{t}+\sigma_{s}+\epsilon_{m, t}, i=1,2
$$

where $V_{m, t}$ is the vote share margin obtained by the candidate from the PT coalition, $I_{m, t}$ denotes the incumbency status of the corresponding party, $\tau$ is the treatment effect, $X_{m, t}$ is a vector of controls, and $\theta_{t}$ and $\sigma_{s}$ are, respectively, year and state fixed effects. The estimating sample pools observations on the 2008 and 2012 mayoral elections and considers only those municipalities-years wherein elections were disputed by a candidate from the PT municipal coalition together with at least one candidate from a party not in that coalition. Under the assumption that municipalities in which the PT coalition candidate either barely won or barely lost are valid counterfactuals for each other (regarding the assessment of incumbency effects), a higher targeting of benefits to voters affiliated to the PT coalition by local governments under control of a party from that coalition may then be interpreted as evidence of clientelism. Table 2.B1 in the appendices displays descriptive statistics for the variables considered.

A critical point is the choice for the bandwidth value, $h$. The narrower the window used in the estimation, the less precise should be the estimates, as the number of observations is reduced. On the other hand, the "as good as random" assumption (and, thus, a smaller bias) is more likely to be valid for smaller windows around the zero vote share margin threshold. Determination of $h$ follows the procedure suggested by Imbens and Kalyanaraman (2012) for an optimal bandwidth choice (IKBW). The resulting bandwidth is fully data-driven and consequently different for each outcome variable $Y$. As robustness checks, we also estimate the incumbency effects using discontinuity samples defined by $h=10 \%, h=5 \%$, and $h=1 \%$.

To assess the validity of the "as good as random" assumption, we evaluate the continuity of the density of our forcing variable at the cutpoint using the test proposed by McCrary (2008). One particular case in which this assumption is not plausible would be if (some) candidates or parties were able to manipulate their final vote shares. In this event, we would expect a noticeable discontinuity in the vote share density at the cutpoint, as (unsuspected) manipulation would most likely be done by candidates who lost by a small margin, and just sufficiently to enable them to win. Figure 2.A1 in the appendices presents an illustration of the test, from which we see that the null hypothesis of continuity of the density is not rejected in any case.

Our baseline results are displayed in Tables 2.1 and 2.2. Panel A of Table 2.1 presents the local polynomial regression estimates of the incumbency effect. We see that the 
estimates for the effect on targeting in the first year after election are always statistically insignificant and also oscillate between positive and negative for different specifications. On the other hand, estimates for the effect on targeting in the second year of the mandate are always positive, but statistically significant at the $5 \%$ level only for the narrower window.

Table 2.1: PT Coalition Incumbency Effects on Bolsa Familia Targeting to Affiliated Voters

\begin{tabular}{lccccc}
\hline & $\begin{array}{c}\text { IKBW } \\
\text { \{obs }\end{array}$ & $(1)$ & $(2)$ & $(3)$ & $(4)$ \\
\hline $\begin{array}{l}\text { Panel A: Baseline Results } \\
\text { Affiliated to PT Coal. }\end{array}$ & $2.87 \%$ & -0.0686 & 0.127 & 0.174 & -0.407 \\
among New Benef. & $\{1,149\}$ & $(0.261)$ & $(0.140)$ & $(0.214)$ & $(0.494)$ \\
in Year 1 (\%) & & & & & \\
Affiliated to PT Coal. & $3.79 \%$ & 0.383 & 0.176 & $0.531^{*}$ & $1.202^{* *}$ \\
among New Benef. & $\{1,501\}$ & $(0.313)$ & $(0.206)$ & $(0.312)$ & $(0.606)$ \\
in Year 2 (\%) & & & & & \\
Panel B: Placebo Tests & & & & & \\
Other Affiliates & $3.35 \%$ & 0.152 & 0.212 & 0.235 & $1.606^{* *}$ \\
among New Benef. & $\{1,321\}$ & $(0.296)$ & $(0.171)$ & $(0.243)$ & $(0.689)$ \\
in Year 1 (\%) & & & & & \\
Other Affiliates & $3.74 \%$ & -0.225 & 0.00891 & -0.149 & 0.521 \\
among New Benef. & $\{1,480\}$ & $(0.358)$ & $(0.217)$ & $(0.309)$ & $(0.647)$ \\
in Year 2 (\%) & & & & & \\
Observations & & - & 3,681 & 1,966 & 382 \\
Bandwidth & & IKBW & $10 \%$ & $5 \%$ & $1 \%$ \\
\hline
\end{tabular}

Standard errors are clustered at the municipality level. The unit of observation is a yearmunicipality, pooling municipal election years from 2008 to 2012. Each figure in columns (1)-(4) is from a separate local linear regression with the specified bandwidth. The IKBW column provides the optimal bandwidth according to Imbens and Kalyanaraman (2012). Controls include: share of the electorate who is affiliated to the corresponding party as of the election year, share of those who got affiliated in the election year, population (log), per capita monthly income (in 2000 reais), a dummy $=1$ if the corresponding state governor is affiliated to the given party, share of literate individuals among those aged 15 or older, share of individuals with a college degree among those aged 25 or older, number of candidates running for office, territorial area $(\log )$, share of beneficiaries, urban population (\%), shares of voters affiliated to the PT coalition and to other parties, a dummy $=1$ if the PT coalition candidate is bidding for reelection, and year and state dummies. ${ }^{*},{ }^{* *}$, and ${ }^{* * *}$ indicate significance at the $10 \%, 5 \%$ and $1 \%$ levels, respectively.

Panel B of Table 2.1, in turn, provides a placebo test by estimating the effect of incumbency by a party from the PT coalition on outcomes that are not expected to be significantly influenced by it under the hypothesis of clientelistic targeting of benefits. Namely, we consider the effect of incumbency by the PT coalition on targeting of benefits 
Table 2.2: Bolsa Família Targeting to Affiliated Voters - Tests of Quasi-Random Assignment

\begin{tabular}{|c|c|c|c|c|c|}
\hline & $\begin{array}{c}\text { IKBW } \\
\{\text { obs }\}\end{array}$ & (1) & $(2)$ & $(3)$ & $(4)$ \\
\hline Population (log) & $\begin{array}{l}2.17 \% \\
\{836\}\end{array}$ & $\begin{array}{l}0.0944 \\
(0.115)\end{array}$ & $\begin{array}{c}0.0213 \\
(0.0554)\end{array}$ & $\begin{array}{c}0.0854 \\
(0.0757)\end{array}$ & $\begin{array}{c}0.161 \\
(0.178)\end{array}$ \\
\hline $\begin{array}{l}\text { Per Capita Monthly } \\
\text { Income }\end{array}$ & $\begin{array}{c}9.66 \% \\
\{3,570\}\end{array}$ & $\begin{array}{l}-3.316 \\
(4.523)\end{array}$ & $\begin{array}{l}-3.917 \\
(4.449)\end{array}$ & $\begin{array}{l}-8.578 \\
(6.288)\end{array}$ & $\begin{array}{l}-4.264 \\
(13.27)\end{array}$ \\
\hline Party State Governor & $\begin{array}{l}1.97 \% \\
\{744\}\end{array}$ & $\begin{array}{l}-0.0639 \\
(0.0596)\end{array}$ & $\begin{array}{l}-0.0332 \\
(0.0247)\end{array}$ & $\begin{array}{l}-0.0255 \\
(0.0355)\end{array}$ & $\begin{array}{c}0.0113 \\
(0.0877)\end{array}$ \\
\hline $\begin{array}{l}\text { Literacy among } 15+ \\
\text { y.o. }(\%)\end{array}$ & $\begin{array}{c}5.16 \% \\
\{2,021\}\end{array}$ & $\begin{array}{l}0.0809 \\
(0.515)\end{array}$ & $\begin{array}{l}-0.375 \\
(0.385)\end{array}$ & $\begin{array}{c}0.147 \\
(0.523)\end{array}$ & $\begin{array}{c}0.00594 \\
(1.201)\end{array}$ \\
\hline $\begin{array}{l}\text { Individuals w/ } \\
\text { College Degree (\%) }\end{array}$ & $\begin{array}{c}3.30 \% \\
\{1,309\}\end{array}$ & $\begin{array}{l}0.0296 \\
(0.206)\end{array}$ & $\begin{array}{r}-0.0431 \\
(0.120)\end{array}$ & $\begin{array}{l}0.0260 \\
(0.171)\end{array}$ & $\begin{array}{c}0.102 \\
(0.384)\end{array}$ \\
\hline Number of Candidates & $\begin{array}{l}2.32 \% \\
\{902\}\end{array}$ & $\begin{array}{c}0.148 \\
(0.111)\end{array}$ & $\begin{array}{c}0.0193 \\
(0.0543)\end{array}$ & $\begin{array}{c}0.0499 \\
(0.0764)\end{array}$ & $\begin{array}{c}0.209 \\
(0.167)\end{array}$ \\
\hline $\begin{array}{l}\text { Log Munic. Area } \\
\left(\mathrm{km}^{2}\right)\end{array}$ & $\begin{array}{c}2.72 \% \\
\{1,078\}\end{array}$ & $\begin{array}{l}0.0956 \\
(0.114)\end{array}$ & $\begin{array}{c}0.0574 \\
(0.0614)\end{array}$ & $\begin{array}{c}0.133 \\
(0.0842)\end{array}$ & $\begin{array}{l}-0.113 \\
(0.195)\end{array}$ \\
\hline Beneficiaries (\%) & $\begin{array}{c}3.65 \% \\
\{1,448\}\end{array}$ & $\begin{array}{c}0.120 \\
(0.292)\end{array}$ & $\begin{array}{c}0.00450 \\
(0.179)\end{array}$ & $\begin{array}{c}0.172 \\
(0.246)\end{array}$ & $\begin{array}{c}0.937 \\
(0.570)\end{array}$ \\
\hline Urban Population (\%) & $\begin{array}{c}4.96 \% \\
\{1,947\}\end{array}$ & $\begin{array}{l}-1.081 \\
(1.706)\end{array}$ & $\begin{array}{l}-1.678 \\
(1.209)\end{array}$ & $\begin{array}{l}-1.171 \\
(1.699)\end{array}$ & $\begin{array}{l}-0.955 \\
(4.214)\end{array}$ \\
\hline $\begin{array}{l}\text { PT Coalition in } \\
\text { Reelection Bid }\end{array}$ & $\begin{array}{l}1.89 \% \\
\{712\}\end{array}$ & $\begin{array}{l}-0.0817 \\
(0.0649)\end{array}$ & $\begin{array}{l}-0.0199 \\
(0.0263)\end{array}$ & $\begin{array}{l}-0.0221 \\
(0.0381)\end{array}$ & $\begin{array}{l}-0.0791 \\
(0.0900)\end{array}$ \\
\hline $\begin{array}{l}\text { Affiliated to PT } \\
\text { Coalition }(\%)\end{array}$ & $\begin{array}{c}3.71 \% \\
\{1,471\}\end{array}$ & $\begin{array}{c}-0.672^{*} \\
(0.353)\end{array}$ & $\begin{array}{l}-0.271 \\
(0.215)\end{array}$ & $\begin{array}{c}-0.628^{* *} \\
(0.300)\end{array}$ & $\begin{array}{l}-0.510 \\
(0.693)\end{array}$ \\
\hline $\begin{array}{l}\text { Affiliated to } \\
\text { Other Parties (\%) }\end{array}$ & $\begin{array}{c}3.76 \% \\
\{1,488\}\end{array}$ & $\begin{array}{l}-0.634 \\
(0.408)\end{array}$ & $\begin{array}{l}-0.434^{*} \\
(0.250)\end{array}$ & $\begin{array}{c}-0.727^{* *} \\
(0.357)\end{array}$ & $\begin{array}{l}-0.455 \\
(0.792)\end{array}$ \\
\hline $\begin{array}{l}\text { Bandwidth } \\
\text { Observations }\end{array}$ & & $\begin{array}{c}\text { IKBW } \\
-\end{array}$ & $\begin{array}{c}10 \% \\
3,681\end{array}$ & $\begin{array}{c}5 \% \\
1,966\end{array}$ & $\begin{array}{l}1 \% \\
382\end{array}$ \\
\hline
\end{tabular}

Standard errors are clustered at the municipality level. The unit of observation is a yearmunicipality, pooling municipal election years from 2008 to 2012. Each figure in columns (1)-(4) is from a separate local linear regression with the specified bandwidth. The IKBW column provides the optimal bandwidth according to Imbens and Kalyanaraman (2012) and the associated number of observations. Year dummies and state dummies are included as controls. ${ }^{*}, * *$, and ${ }^{* * *}$ indicate significance at the $10 \%, 5 \%$ and $1 \%$ levels, respectively. 
to voters affiliated to parties outside the PT municipal coalition. The event of finding robust and significant estimates for such an effect could suggest, for instance, that mayors from the PT coalition are for some reason associated with a higher targeting of benefits to affiliated voters regardless of their party, which would compromise the interpretation of benefits being targeted as electoral rewards. ${ }^{23}$ However, the corresponding estimates are almost always statistically insignificant. A graphical illustration of the results in Panels $\mathrm{A}$ and $\mathrm{B}$ is provided by Figure 2.A2 in the appendices.

In addition, Table 2.2 provides the standard robustness check of testing for treatment effects on pre-determined covariates, which are the ones employed as controls in equation 2.3. We observe that the quasi-random assignment of treatment seems to be a valid hypothesis in our case, since the corresponding estimates are overall insignificant and the few that are not so are specific to certain discontinuity samples.

Despite the absence of a significant and robust effect in our baseline results, further investigation reveals that the effect of incumbency by a PT coalition candidate on clientelistic targeting may be more relevant for some subgroups of municipalities. Table 2.3 presents the results obtained from repeating the estimation of model (2.3) after dividing our sample into subsamples of municipalities with populations below and above the median. For brevity, we focus on the estimates of the effect of incumbency on clientelistic targeting in the second year of the mandate, as the ones related to targeting in the first year are always statistically insignificant. ${ }^{24}$ Panel A presents the estimated treatment effects considering municipalities with relatively low populations. We see that a statistically significant effect is found for all specifications but the one related to the larger window.

The point estimate obtained by employing the optimal bandwidth suggests that local government incumbency by a mayor affiliated to a party in the PT coalition is associated with a 1.4 percentage point increase in the share of voters affiliated to a party in that coalition among the individuals who start receiving Bolsa Familia payments in the second year of the mayoral mandate. Meanwhile, the corresponding share of affiliated voters in small-population municipalities where the PT coalition lost by a small margin is estimated to be around $2.5 \%{ }^{25}$ Hence, local incumbency by a party in the PT coalition is associated with an increase of almost $60 \%$ in that share. Also, it is important to notice that the magnitude of the estimated effect is larger the smaller the bandwidth defining the discontinuity sample. This may reflect the possibility that incumbents are

\footnotetext{
${ }^{23}$ Due to issues of symmetry, the estimates in Panel B also represent the effect of incumbency by a party not in the PT municipal coalition on clientelistic targeting of voters affiliated to a party outside that coalition, but with the opposite sign.

${ }^{24}$ These results are available from the author upon request.

${ }^{25}$ This figure corresponds to the value of the intercept in model $(2.3), \alpha$, estimated under the optimal bandwidth without control variables $\mathbf{X}_{\mathbf{m}, \mathbf{t}}$ and fixed effects $\theta_{t}$ and $\sigma_{s}$.
} 
Table 2.3: BF Targeting to Affiliated Voters, by Population Size - Baseline Results

\begin{tabular}{|c|c|c|c|c|c|}
\hline & $\begin{array}{c}\text { IKBW } \\
\{\text { obs }\}\end{array}$ & $(1)$ & $(2)$ & $(3)$ & $(4)$ \\
\hline \multicolumn{6}{|c|}{ Panel A: Municipalities with Below-Median Population } \\
\hline $\begin{array}{l}\text { Affiliated to PT Coal. } \\
\text { among New Benef. } \\
\text { in Year } 2(\%)\end{array}$ & $\begin{array}{l}4.66 \% \\
\{916\}\end{array}$ & $\begin{array}{l}1.414^{* *} \\
(0.661)\end{array}$ & $\begin{array}{c}0.497 \\
(0.399)\end{array}$ & $\begin{array}{l}1.282^{* *} \\
(0.594)\end{array}$ & $\begin{array}{l}2.655^{* *} \\
(1.293)\end{array}$ \\
\hline Observations & & - & 1,860 & 994 & 185 \\
\hline \multicolumn{6}{|c|}{ Panel B: Municipalities with Above-Median Population } \\
\hline $\begin{array}{l}\text { Affiliated to PT Coal. } \\
\text { among New Benef. } \\
\text { in Year } 2(\%)\end{array}$ & $\begin{array}{l}3.09 \% \\
\{618\}\end{array}$ & $\begin{array}{l}-0.189 \\
(0.250)\end{array}$ & $\begin{array}{l}-0.153 \\
(0.127)\end{array}$ & $\begin{array}{l}-0.138 \\
(0.185)\end{array}$ & $\begin{array}{l}-0.164 \\
(0.377)\end{array}$ \\
\hline Observations & & - & 1,821 & 972 & 197 \\
\hline $\begin{array}{l}\text { Test of Equality } \\
\text { in TEs (p-value) }\end{array}$ & & 0.020 & 0.117 & 0.020 & 0.019 \\
\hline Bandwidth & & IKBW & $10 \%$ & $5 \%$ & $1 \%$ \\
\hline
\end{tabular}

All notes to Table 2.1 apply.

more prone to resorting to that kind of clientelistic targeting in situations where their electoral advantage is predicted to be smaller and the need to secure a certain quantity of votes is more crucial for staying in office. In addition, the fact that significant estimates are found for such an effect in the second years of mayoral mandates - when state and federal elections are held-but not in the first further indicates that the distribution of benefits to affiliated voters is made for electoral motives.

On the other hand, estimates for the treatment effect in municipalities with relatively large populations (reported in Panel B) are negative and statistically insignificant. The null hypothesis of equality in the treatment effects for the two groups of municipalities is rejected in three of the four specifications. Our finding that significantly estimated effects are restricted to municipalities with small populations may be because any individual vote is relatively more important in shaping candidates' destinies in municipalities with fewer voters compared to municipalities with large electorates. Thus, the marginal cost of targeting one additional (affiliated) voter in a clientelistic fashion should be lower for officials in municipalities with smaller populations. Alternatively, the capacity by local officials to covertly target benefits may arguably be limited to a certain absolute number of targeted voters regardless of the population size. In that case, assuming that municipalities with larger populations have on average a larger (absolute) number of 
new beneficiaries each year, the relative degree of clientelistic targeting (as measured by the variables defined in equation (2.2) ) should be lower for municipalities with larger populations.

Lastly, Table 2.4 presents the results of the aforementioned placebo test applied to each of the subsamples. We see that the corresponding estimates are statistically insignificant except for one of the specifications regarding municipalities with relatively large populations. The validity of the RD design applied to these subsamples is also reinforced by the results presented in Tables 2.B2 and 2.B3 in the appendices, which indicate that the quasi-random assignment of treatment remains a valid hypothesis for each municipality group.

Table 2.4: BF Targeting to Affiliated Voters, by Population Size - Placebo Tests

\begin{tabular}{|c|c|c|c|c|c|}
\hline & $\begin{array}{c}\text { IKBW } \\
\{\mathrm{obs}\}\end{array}$ & $(1)$ & $(2)$ & $(3)$ & $(4)$ \\
\hline \multicolumn{6}{|c|}{ Panel A: Municipalities with Below-Median Population } \\
\hline $\begin{array}{l}\text { Other Affiliates } \\
\text { among New Benef. } \\
\text { in Year } 2(\%)\end{array}$ & $\begin{array}{l}3.99 \% \\
\{797\}\end{array}$ & $\begin{array}{l}0.0645 \\
(0.649)\end{array}$ & $\begin{array}{c}0.120 \\
(0.402)\end{array}$ & $\begin{array}{l}0.0162 \\
(0.575)\end{array}$ & $\begin{array}{c}0.859 \\
(1.380)\end{array}$ \\
\hline Observations & & - & 1,860 & 994 & 185 \\
\hline \multicolumn{6}{|c|}{ Panel B: Municipalities with Above-Median Population } \\
\hline $\begin{array}{l}\text { Other Affiliates } \\
\text { among New Benef. } \\
\text { in Year } 2(\%)\end{array}$ & $\begin{array}{l}3.50 \% \\
\{684\}\end{array}$ & $\begin{array}{c}-0.584^{* *} \\
(0.282)\end{array}$ & $\begin{array}{l}-0.133 \\
(0.148)\end{array}$ & $\begin{array}{l}-0.296 \\
(0.225)\end{array}$ & $\begin{array}{c}0.413 \\
(0.449)\end{array}$ \\
\hline Observations & & - & 1,821 & 972 & 197 \\
\hline $\begin{array}{l}\text { Test of Equality } \\
\text { in TEs (p-value) }\end{array}$ & & 0.346 & 0.550 & 0.605 & 0.732 \\
\hline Bandwidth & & IKBW & $10 \%$ & $5 \%$ & $1 \%$ \\
\hline
\end{tabular}

All notes to Table 2.1 apply.

\subsubsection{Local Government Incumbency and Party Affiliation}

In light of the results discussed above, it is important to gain some further understanding on the (possibly indirect) ability of incumbents of local governments to induce voter affiliation. Even if voters' decisions to become affiliated to a political party are not necessarily motivated by clientelistic reasons, our previous findings suggest that incumbents may have an incentive to promote affiliation (and to identify its determinants) in order 
to experience a higher efficacy of future vote-buying attempts.

In this section, we begin the investigation of this issue by exploring the causal effect of local government incumbency on levels of party affiliation, which is done once again by means of a regression discontinuity design applied to municipal elections. We follow the same approach outlined in the previous section and provide non-parametric, local linear regression estimates of the treatment effects by estimating the equation

$$
Y_{p, m, t}=\alpha+\tau_{p} I_{p, m, t}+\beta_{0} V_{p, m, t}+\beta_{1} V_{p, m, t} I_{p, m, t}+\gamma^{\prime} \mathbf{X}_{\mathbf{p}, \mathbf{m}, \mathbf{t}}+\theta_{t}+\sigma_{s}+\epsilon_{p, m, t}
$$

using only those observations of municipalities-years wherein party $p$ won or lost by a small margin. Here, $Y_{p, m, t}$ is taken to be the percentage of the electorate in $m$ which became affiliated to $p$ in the four years following election in $t$ (i.e. during the next mayoral mandate), $\tau_{p}$ is the effect of incumbency by $p, V_{p, m, t}$ is $p$ 's vote share margin, $I_{p, m, t}$ is the incumbency status, $X_{p, m, t}$ is a vector of control variables included to enhance the precision of our estimates, and $\theta_{t}$ and $\sigma_{s}$ are, respectively, year and state fixed effects. We present estimates of $\tau_{p}$ for three of the parties with the largest numbers of affiliated voters in Brazil: the PMDB, the PSDB, and the PT. ${ }^{26,27}$ Each party sample pools observations of four cycles of municipal elections from 1996 to 2008, and we consider (as in the last section) the optimal bandwidth suggested by Imbens and Kalyanaraman (2012) as well as discontinuity samples defined by bandwidths $h=10 \%, h=5 \%$, and $h=1 \%$ as robustness checks. Descriptive statistics for the variables involved are provided in Table $2 . \mathrm{B} 4$ in the appendices.

To check whether municipalities above and below the cutpoint are comparable, we estimate effects of local government incumbency on the pre-determined variables introduced in equation 2.4 as controls. Tables 2.B5 2.B7 present the corresponding results for each party sample. Overall, we see that almost all effects are statistically insignificant and that the few that are not tend to be so only for specific discontinuity samples. Moreover, Figure 2.A3 in the appendices illustrates the test proposed by McCrary (2008) for each of the party samples used in our analysis; we see that the null hypothesis of continuity of the density is not rejected in any case.

Before reporting the main results of this section, we provide some graphical evidence. Figure 2.A4 in the appendices plots the residuals of regressions of the outcome of interest

\footnotetext{
${ }^{26} \mathrm{PMDB}, \mathrm{PSDB}$ and PT are acronyms for Partido do Movimento Democrático Brasileiro, Partido da Social Democracia Brasileira, and Partido dos Trabalhadores, respectively.

${ }^{27}$ As of January 2015, the PMDB and the PT are the two parties with the most affiliated voters, while the PSDB is ranked in fourth position. The Partido Progressista (PP) is the third party in terms of the number of affiliated voters. However, in recent years the PP has gone through name changes and mergers with other parties, and for these reasons has been omitted from the analysis.
} 
(the share of the electorate who became affiliated to the corresponding party in the four years following election) on the controls listed in Tables 2.B5 2.B7 against the forcing variable for each of the party samples. Each point is the mean of the residuals within $1 \%$ intervals of the vote share margin. Also, a quadratic polynomial is fitted on the original data at each side of the cutpoint and setting $h=20$. We observe that, for all parties, the polynomial fit illustrates a positive jump at the zero vote margin threshold and thus suggests the existence of a positive effect of incumbency on affiliation to the corresponding party. However, we also see from the confidence intervals that such an effect tends to be statistically insignificant.

The same conclusions are drawn from our local linear regression estimates of the treatment effects, presented in Table 2.5 below. We observe that the point estimates for the three parties considered are quite similar and suggest that local government incumbency accounts for an increase in party affiliation along the mayoral mandate in the order of $0.1 \%$ of the municipal electorate, arguably a fairly low figure. Furthermore, none of the estimated coefficients is statistically significant at the $5 \%$ level. Thus, our results indicate that incumbency at the local level may not be a relevant factor in the expansion of parties' troops of formal supporters.

We also explore whether the effect of incumbency on party affiliation is heterogeneous among municipalities with distinct levels of literacy. ${ }^{28}$ Tables 2.6 and 2.7 present the results obtained from repeating the estimation of model (2.4), but dividing each party sample into two subsamples: municipalities with shares of literate individuals (among those aged 15 or older) below and above the median. Tables 2.B8 2.B13 in the appendices provide robustness checks for the RD design applied to those subsamples, and suggest that imbalance is not a serious issue.

Panels A and B of Table 2.6 indicate that incumbency seems not to significantly impact party affiliation for the PMDB and the PSDB in any of the literacy-based groups of municipalities. Once again, estimates of the treatment effect are overall statistically insignificant. Moreover, at the $5 \%$ level we do not reject the null hypothesis that the effects for municipalities in each group are the same.

On the other hand, results reported in Table 2.7 provide evidence that local incumbency by the PT may perform a more significant role in municipalities with less educated voters regarding the affiliation of voters. For this group of municipalities, statistically significant estimates are found for all specifications but the one that considers $h=1 \%$ (where

\footnotetext{
${ }^{28}$ Estimates produced from exploring heterogeneity in the effect along other dimensions captured by the control variables employed do not reveal any clear pattern and are therefore omitted. These results are available from the author upon request.
} 
Table 2.5: Incumbency Effects on Voter Affiliation - Baseline Results

\begin{tabular}{|c|c|c|c|c|c|}
\hline & IKBW & (1) & $(2)$ & $(3)$ & (4) \\
\hline \multicolumn{6}{|l|}{ Panel A: PMDB } \\
\hline $\begin{array}{l}\text { Affiliated in the Next } \\
4 \text { Years }(\%)\end{array}$ & $2.50 \%$ & $\begin{array}{c}0.103 \\
(0.117)\end{array}$ & $\begin{array}{c}0.0146 \\
(0.0593)\end{array}$ & $\begin{array}{c}0.0923 \\
(0.0834)\end{array}$ & $\begin{array}{c}0.152 \\
(0.224)\end{array}$ \\
\hline Observations & & 1,144 & 4,313 & 2,282 & 452 \\
\hline \multicolumn{6}{|l|}{ Panel B: PSDB } \\
\hline $\begin{array}{l}\text { Affiliated in the Next } \\
4 \text { Years }(\%)\end{array}$ & $2.47 \%$ & $\begin{array}{c}0.130 \\
(0.112)\end{array}$ & $\begin{array}{c}0.0746 \\
(0.0562)\end{array}$ & $\begin{array}{c}0.126^{*} \\
(0.0745)\end{array}$ & $\begin{array}{l}0.0250 \\
(0.238)\end{array}$ \\
\hline Observations & & 733 & 2,937 & 1,542 & 296 \\
\hline \multicolumn{6}{|l|}{ Panel $C: P T$} \\
\hline $\begin{array}{l}\text { Affiliated in the Next } \\
4 \text { Years }(\%)\end{array}$ & $2.42 \%$ & $\begin{array}{c}0.155 \\
(0.191)\end{array}$ & $\begin{array}{c}0.149^{*} \\
(0.0776)\end{array}$ & $\begin{array}{c}0.103 \\
(0.115)\end{array}$ & $\begin{array}{c}0.176 \\
(0.262)\end{array}$ \\
\hline Observations & & 311 & 1,200 & 634 & 140 \\
\hline Bandwidth & & IKBW & $10 \%$ & $5 \%$ & $1 \%$ \\
\hline
\end{tabular}

Standard errors are robust to clustering at the municipality level. The unit of observation is a year-municipality, pooling municipal election years from 1996 to 2008 . Each figure in columns (1)-(4) is from a separate local linear regression with the specified bandwidth. The IKBW column provides the optimal bandwidth according to Imbens and Kalyanaraman (2012). Controls include: share of the electorate who is affiliated to the corresponding party as of the election year, share of those who got affiliated in the election year, population (log), per capita monthly income (in 2000 reais), a dummy $=1$ if the corresponding state governor is affiliated to the given party, share of literate individuals among those aged 15 or older, number of candidates running for office, territorial area $(\log )$, and year and state dummies. *, **, and *** indicate significance at the $10 \%$, $5 \%$ and $1 \%$ levels, respectively.

the number of observations is very low), and imply that the effect of incumbency on party affiliation is in the $0.2-0.4$ percentage point range. Also, for those low-literacy municipalities where the PT lost by a small margin, the estimated proportion of the electorate who becomes affiliated to the PT is around $0.21 \% .{ }^{29}$ Thus, in relative terms, local incumbency by the PT is associated with an increase of $100-225 \%$ in affiliation to that party, a fairly large magnitude. The null hypothesis of equality in the treatment effects for the two groups of municipalities is rejected in two cases.

To conclude, it is worthwhile noting that the results found for the PT regarding municipalities with a relatively less educated population go in the opposite direction to the fre-

\footnotetext{
${ }^{29}$ This figure corresponds to the value of the intercept in model $(2.4), \alpha$, estimated under the optimal bandwidth without control variables $\mathbf{X}_{\mathbf{p}, \mathbf{m}, \mathbf{t}}$ and fixed effects $\theta_{t}$ and $\sigma_{s}$.
} 
quently argued notion that political participation is favored by higher levels of education. One possible explanation (consistent with our previous findings) is that party affiliation in these contexts is something actively pursued - rather than passively regarded — by parties and elected governments. In any case, however, our results suggest that this situation is not widespread across parties.

Table 2.6: Incumbency Effects on Voter Affiliation, by Literacy Rate (1/2)

\begin{tabular}{|c|c|c|c|c|c|}
\hline & IKBW & (1) & $(2)$ & $(3)$ & $(4)$ \\
\hline \multicolumn{6}{|l|}{ Panel $A: P M D B$} \\
\hline \multicolumn{6}{|c|}{ Municipalities with Below-Median Literacy } \\
\hline $\begin{array}{l}\text { Affiliated in the Next } \\
4 \text { Years }(\%)\end{array}$ & $2.83 \%$ & $\begin{array}{c}0.102 \\
(0.172)\end{array}$ & $\begin{array}{c}0.121 \\
(0.0825)\end{array}$ & $\begin{array}{l}0.205^{*} \\
(0.113)\end{array}$ & $\begin{array}{c}0.286 \\
(0.248)\end{array}$ \\
\hline Observations & & 554 & 1,864 & 976 & 190 \\
\hline \multicolumn{6}{|c|}{ Municipalities with Above-Median Literacy } \\
\hline $\begin{array}{l}\text { Affiliated in the Next } \\
4 \text { Years }(\%)\end{array}$ & $2.18 \%$ & $\begin{array}{l}0.0868 \\
(0.183)\end{array}$ & $\begin{array}{l}-0.0711 \\
(0.0813)\end{array}$ & $\begin{array}{r}-0.0115 \\
(0.120)\end{array}$ & $\begin{array}{r}-0.0262 \\
(0.356)\end{array}$ \\
\hline Observations & & 567 & 2,449 & 1,306 & 262 \\
\hline $\begin{array}{l}\text { Test of Equality } \\
\text { in TEs ( } p \text {-value) }\end{array}$ & & 0.950 & 0.092 & 0.183 & 0.440 \\
\hline \multicolumn{6}{|l|}{ Panel B: PSDB } \\
\hline \multicolumn{6}{|c|}{ Municipalities with Below-Median Literacy } \\
\hline $\begin{array}{l}\text { Affiliated in the Next } \\
4 \text { Years }(\%)\end{array}$ & $2.36 \%$ & $\begin{array}{l}0.0790 \\
(0.117)\end{array}$ & $\begin{array}{l}0.166^{* *} \\
(0.0734)\end{array}$ & $\begin{array}{c}0.106 \\
(0.0869)\end{array}$ & $\begin{array}{r}-0.0836 \\
(0.230)\end{array}$ \\
\hline Observations & & 340 & 1,427 & 763 & 151 \\
\hline \multicolumn{6}{|c|}{ Municipalities with Above-Median Literacy } \\
\hline $\begin{array}{l}\text { Affiliated in the Next } \\
4 \text { Years }(\%)\end{array}$ & $2.75 \%$ & $\begin{array}{l}0.310^{*} \\
(0.180)\end{array}$ & $\begin{array}{c}-0.00546 \\
(0.0874)\end{array}$ & $\begin{array}{c}0.204 \\
(0.128)\end{array}$ & $\begin{array}{l}0.0342 \\
(0.363)\end{array}$ \\
\hline Observations & & 427 & 1,510 & 779 & 145 \\
\hline $\begin{array}{l}\text { Test of Equality } \\
\text { in TEs ( } p \text {-value) }\end{array}$ & & 0.263 & 0.130 & 0.515 & 0.759 \\
\hline Bandwidth & & IKBW & $10 \%$ & $5 \%$ & $1 \%$ \\
\hline
\end{tabular}

See notes to Table 2.5 . 
Table 2.7: Incumbency Effects on Voter Affiliation, by Literacy Rate (2/2)

\begin{tabular}{|c|c|c|c|c|c|}
\hline & IKBW & (1) & $(2)$ & $(3)$ & (4) \\
\hline \multicolumn{6}{|l|}{ Panel C: PT } \\
\hline \multicolumn{6}{|c|}{ Municipalities with Below-Median Literacy } \\
\hline $\begin{array}{l}\text { Affiliated in the Next } \\
4 \text { Years }(\%)\end{array}$ & $3.13 \%$ & $\begin{array}{c}0.451^{* *} \\
(0.228)\end{array}$ & $\begin{array}{l}0.211^{*} \\
(0.125)\end{array}$ & $\begin{array}{c}0.459^{* *} \\
(0.185)\end{array}$ & $\begin{array}{l}0.0534 \\
(0.773)\end{array}$ \\
\hline Observations & & 176 & 472 & 252 & 60 \\
\hline \multicolumn{6}{|c|}{ Municipalities with Above-Median Literacy } \\
\hline $\begin{array}{l}\text { Affiliated in the Next } \\
4 \text { Years }(\%)\end{array}$ & $2.56 \%$ & $\begin{array}{l}-0.165 \\
(0.146)\end{array}$ & $\begin{array}{c}0.114 \\
(0.0881)\end{array}$ & $\begin{array}{l}-0.141 \\
(0.118)\end{array}$ & $\begin{array}{l}-0.154 \\
(0.246)\end{array}$ \\
\hline Observations & & 196 & 728 & 382 & 80 \\
\hline $\begin{array}{l}\text { Test of Equality } \\
\text { in TEs (p-value) }\end{array}$ & & 0.009 & 0.488 & 0.002 & 0.711 \\
\hline Bandwidth & & IKBW & $10 \%$ & $5 \%$ & $1 \%$ \\
\hline
\end{tabular}

See notes to Table 2.5

\subsubsection{The Impact of Bolsa Familia Coverage on Party Affiliation}

As suggested by the results presented in Section 2.4.1, the provision of Bolsa Familia payments may in some cases be used in rewarding voters affiliated to incumbent parties for their loyalty. We now extend our investigation of political determinants of party affiliation by exploring the complementary question of whether the receipt of benefits from the Bolsa Familia may induce voters to become affiliated to a political party. In light of the discretionary character of those provisions (combined with previous results), the existence of a causal relationship between Bolsa Família coverage and party affiliation may be driven by the establishment of a clientelistic arrangement wherein local governments explicitly try to buy new affiliations through targeting benefits. Alternatively, though, party affiliation may be a result of receiving Bolsa Familia benefits simply because beneficiaries approve of the conduct of the program and choose to manifest their support by affiliating to the party they deem responsible for that conduct.

The main empirical challenge in the identification of a causal effect of the Bolsa Familia on party affiliation stems from the fact that party affiliation may be correlated with unobserved socioeconomic characteristics, which are themselves correlated with Bolsa Familia coverage - since that coverage is determined by socioeconomic criteria. For instance, we could expect municipalities with large proportions of beneficiaries to present low levels 
of education and, consequently, lower political participation. Of course, this problem could also be present in the time series, as municipalities experiencing improvements in economic conditions may be related to reductions in coverage and to higher levels of education and political participation. In this simple case, ordinarily estimating a regression of party affiliation on the share of the population covered by the program would produce (negatively) biased results even when controlling for municipality fixed effects. Alternatively, it is possible that Bolsa Familia coverage in a given municipality is determined to a certain degree by the political orientation of its residents, leading to a simultaneity bias.

In order to overcome these endogeneity issues, we adopt an instrumental variables approach that exploits an expansion of the Bolsa Familia program. As described earlier in the chapter, benefits from Bolsa Familia were extended in 2008 to families with adolescents aged 16 or 17 through the Variable Youth Benefit. By combining the timing of this expansion with information on the demographic composition of municipalities, we can construct an instrument for Bolsa Familia coverage. In particular, we assume that the age composition of municipalities was indeed associated with changes in coverage after 2008, and that there is no other reason (aside from program expansion) why party affiliation by the groups affected by the expansion would be significantly altered in 2008 .

We estimate the model

$$
\text { affiliated }_{m, t}=\alpha+\beta B F_{m, t}+\gamma^{\prime} \mathbf{X}_{\mathbf{m}, \mathbf{t}}+\delta_{t}+\mu_{m}+\epsilon_{m, t}
$$

where af filiated $_{m, t}$ denotes the percentage of individuals affiliated to a political party in municipality $m$ and year $t, B F_{m, t}$ denotes the percentage of beneficiaries (measured by the number of beneficiary families over total population) in December, $X_{m, t}$ is a vector of control variables, and $\delta_{t}$ and $\mu_{m}$ are year and municipality fixed effects, respectively. Some of the control variables are employed at the state - rather than the municipallevel in order to avoid further endogeneity issues. Our instrument for $B F_{m, t}$ (henceforth denoted by inst_vyb $b_{m, t}$ ) is the interaction of a dummy variable equal to one in 2008 and after with an estimate of the share of the population in $m$ aged 16 or 17 in December of year $t$ (as such information is not available for every year).

These estimates, in turn, are constructed in the following way. For a given year $t$, the share of the population in $m$ aged 16 or 17 in December is taken to be the percentage of individuals in $m$ aged between $15-\left(t-t_{0}\right)$ and $17-\left(t-t_{0}\right)$ in $t_{0}$, where $t_{0}$ is the year of the most recent population census (before $t$ ). For a concrete example, the share of the population in a given municipality $m$ aged 16-17 in December 2004 is taken to be the share of individuals aged between $11(15-(2004-2000))$ and $13(17-(2004-2000))$ 
in 2000, as reported by the 2000 population census. In particular, our estimates do not take into account possible migration issues. ${ }^{30}$ The sample used in this analysis covers observations of Brazilian municipalities from 2004 to 2012. Table 2.B14 in the appendices provides descriptive statistics for the variables employed in equation (2.5).

Table 2.8 presents our main results. The first column displays the result of a simple OLS regression of the percentage of affiliated individuals on the percentage of beneficiaries, with no additional controls, from which we obtain a negative and statistically significant estimated correlation. The second column adds year dummies and demographic and socioeconomic controls (reported in Table 2.B14). Addition of those control variables reduces the estimated coefficient's magnitude by more than half, but the estimate is still negative and significant. The third column considers the introduction of municipality fixed effects by estimating equation (2.5) after a within transformation of the data. The estimated correlation then becomes positive (although practically negligible in magnitude) and remains statistically significant, which suggests the existence of some cross-sectional variation in Bolsa Familia coverage that is negatively associated with party affiliation. This would be the case of the omitted variables scenario illustrated at the beginning of the subsection, according to which higher levels of coverage- both across and within municipalities - could be associated with lower levels of education and a resulting lower level of political participation. Finally, the fourth column presents our IV estimates, where Bolsa Familia coverage is treated as endogenous. After using our instrument to isolate the exogenous variation in the percentage of beneficiaries, our estimate maintains a positive sign and is still statistically significant, but becomes quite larger in magnitude. Thus, the assumed endogeneity of within municipality variation also seems to produce a negative bias in OLS estimates of the effect.

The point estimate presented in column 4 suggests that a 1 percentage point increase in the share of the population who is a head of household and receives payments from Bolsa Familia corresponds to approximately a 0.17 percentage point increase in the share of party-affiliated individuals. If we assume that beneficiary families have an average of four individuals each, and that this figure is uniform across municipalities, then an alternative interpretation of our estimate is that a 1 percentage point increase in the share of individuals who belong to a beneficiary family corresponds to a $0.0425(0.17 / 4)$ percentage point increase in the share of affiliated voters, which amounts to almost one affiliated voter per 20 beneficiaries. ${ }^{31}$ It is useful to note, however, that with heterogeneous

\footnotetext{
${ }^{30}$ Population censuses in Brazil establish the August 1 of the corresponding year as the reference date for calculation of individuals' ages. As such, while consideration of the interval $\left[15-\left(t-t_{0}\right) ; 17-\left(t-t_{0}\right)\right]$ leads to an upper bound of the share of individuals aged 16 or 17 in December (assuming no migration), using the interval $\left[16-\left(t-t_{0}\right) ; 17-\left(t-t_{0}\right)\right.$ would generate a lower bound to that quantity. Nonetheless, our results are qualitatively unchanged upon consideration of the latter interval.

${ }^{31}$ Alternatively, we have employed a measure of the share of beneficiaries based on the ratio of the
} 
Table 2.8: Effect of Bolsa Familia on Party Affiliation - Baseline Results

\begin{tabular}{lcccc}
\hline $\begin{array}{l}\text { Dep. Variable: } \\
\text { \% of Affiliated Voters }\end{array}$ & OLS & OLS & OLS & IV \\
\hline & & & & \\
Beneficiaries (\%) & $-0.298^{* * *}$ & $-0.114^{* * *}$ & $0.0357^{* * *}$ & $0.170^{* * *}$ \\
& $(0.0165)$ & $(0.0180)$ & $(0.00665)$ & $(0.0205)$ \\
& & & & \\
Year Dummies & Yes & Yes & Yes & Yes \\
Controls & No & Yes & Yes & Yes \\
Mun. Fixed Effects & No & No & Yes & Yes \\
Observations & 49,322 & 49,322 & 49,322 & 49,322 \\
\hline
\end{tabular}

Standard errors are clustered at the municipality level. The unit of observation is a year-municipality. Controls include: population (log), per capita monthly income at the state level (in 2000 reais), share of literate individuals among those aged 15 or older (state level), share of individuals with a college degree among those aged 25 or older (state level), territorial area $(\log )$, urban population (\%), and expected proportion of 16- and 17-year-olds. The instrument employed in the IV regression is the expected proportion of 16- and 17-year-olds interacted with a dummy $=1$ for years 2008 to 2012. ${ }^{*}, * *$, and $* * *$ indicate significance at the $10 \%, 5 \%$ and $1 \%$ levels, respectively.

treatment effects the IV estimate represents an average impact on affiliation that gives more weight to those municipalities most affected by the expansion in the program. Those municipalities, in turn, would be the ones with a large proportion of 16- and 17-year-olds and of poor individuals, who are arguably less likely to become affiliated. In this sense, the magnitude of the estimated effect seems actually quite relevant.

The first stage of our instrumental variables strategy is reported in Table 2.9. Column 1 presents the results of a simple regression of our measure of coverage on the instrument, the expected proportion of 16- and 17-year-olds (after 2008), and time dummies, while the second column includes socioeconomic and demographic control variables. Column 3 accounts for municipality fixed effects and is the actual first stage related to column 4 of Table 2.8. We notice that, in all cases, the estimated correlation points to a positive and statistically significant relationship between coverage and the instrument. The estimated coefficient's magnitude remains fairly stable as controls and municipality fixed effects are included and is close to one. Also, the F statistic displayed is particularly large and indicates that we do not have a weak instrument problem. The point estimate in column 3 suggests that a municipality with a share of 16- and 17-year-olds 1 percentage point higher in a year after the expansion would be associated with a share of (head of

number of head of household beneficiaries over the number of families in the corresponding municipality, according to census data. In that case, our instrument is analogously redefined to be the interaction of the dummy variable equal to one in 2008 an after with the share of families with at least one member aged 16 or 17 . However, the concept of family as defined by the census authority is also based on criteria other than kinship, so that a family could in practice comprise more than one head of household beneficiary. Nonetheless, the corresponding results are qualitatively similar and are available upon request. 
household) beneficiaries 0.85 percentage points higher.

Table 2.9: First Stage - Bolsa Família Beneficiaries (\%) Regressed on Instrument

$(1)$

$(2)$

(3)

\begin{tabular}{lccc} 
Instrument & $0.979^{* * *}$ & $1.145^{* * *}$ & $0.852^{* * *}$ \\
& $(0.0351)$ & $(0.0268)$ & $(0.0197)$ \\
& & & \\
Year Dummies & Yes & Yes & Yes \\
Controls & No & Yes & Yes \\
Mun. Fixed Effects & No & No & Yes \\
F-statistic of Instrument & 776.1 & 1824.2 & 1868.9 \\
Observations & 49,322 & 49,322 & 49,322 \\
\hline
\end{tabular}

Standard errors are robust to clustering at the municipality level. The unit of observation is a year-municipality. The dependent variable is the share of people receiving payments in December. Controls include: population (log), per capita monthly income at the state level (in 2000 reais), share of literate individuals among those aged 15 or older (state level), share of individuals with a college degree among those aged 25 or older (state level), territorial area (log), and urban population (\%). All columns include the expected proportion of 16- and 17-year-olds as a regressor. The instrument is the expected proportion of 16- and 17-year-olds interacted with a dummy $=1$ for years 2008 to $2012 .{ }^{*},{ }^{* *}$, and ${ }^{* * *}$ indicate significance at the $10 \%, 5 \%$ and $1 \%$ levels, respectively.

Lastly, we perform some robustness checks of our instrumental variables approach. This is done by including as additional controls in our regressions certain variables that are closely related to the instrument employed in our baseline results, but that do not capture the precise character of the program expansion in 2008. Specifically, we include as regressors the expected proportion of people aged $x(x=10,15,20,40$ and 60$)$ and its interaction with a dummy variable equal to one for years 2008 to 2012 . As those variables refer to age groups unrelated to the expansion criteria, a high sensitivity of the main estimated coefficient upon their inclusion could cast serious doubts on the exogeneity of our instrument. Such a sensitivity would be expected, for instance, if changes in municipal rates of affiliated voters before and after 2008 were fundamentally dependent on the demographic composition of municipalities. Alternatively, our original results could suffer from an omitted variables bias if the expansion of the Bolsa Familia in 2008 was not restricted to families with 16 - and 17 -year-olds. Table 2.10 displays the corresponding results. Column 1 replicates the estimates presented in column 4 of Table 2.8, whereas columns 2 to 6 present the results obtained after the inclusion of the variables related to each of the alternative age groups. We see that our baseline estimate is close to the minimum value of 0.132 obtained from introducing variables corresponding to the proportion of 15-year-olds (column 3), the age group closest to that directly affected by the Variable Youth Benefit. Also, the inclusion of variables related to higher age groups leads to estimates of greater magnitude. This in turn suggests that our baseline results may 
actually be closer to a lower bound to the true effect of Bolsa Familia coverage on party affiliation, and that a possible bias in the estimated effect is more likely to be of negative sign.

Table 2.10: Effect of Bolsa Familia on Party Affiliation - Robustness Checks

\begin{tabular}{lcccccc}
\hline $\begin{array}{l}\text { Dep. Variable: } \\
\text { \% of Affiliated Voters }\end{array}$ & $(1)$ & $(2)$ & $(3)$ & $(4)$ & $(5)$ & $(6)$ \\
\hline & IV & IV & IV & IV & IV & IV \\
Beneficiaries (\%) & $0.170^{* * * *}$ & $0.138^{* * *}$ & $0.132^{* * *}$ & $0.280^{* * *}$ & $0.231^{* * * *}$ & $0.257^{* * *}$ \\
& $(0.0205)$ & $(0.0462)$ & $(0.0396)$ & $(0.0333)$ & $(0.0270)$ & $(0.0258)$ \\
& & & & & & \\
Added Regressors & - & Int_10 & Int_15 & Int_20 & Int_40 & Int_60 \\
Observations & 49,322 & 49,322 & 49,322 & 49,322 & 49,322 & 49,322 \\
\hline
\end{tabular}

Standard errors are robust to clustering at the municipality level. The unit of observation is a yearmunicipality. Controls include: population (log), per capita monthly income at the state level (in 2000 reais), share of literate individuals among those aged 15 or older (state level), share of individuals with a college degree among those aged 25 or older (state level), territorial area (log), urban population (\%), expected proportion of 16- and 17-year-olds, year dummies, and municipality fixed effects. The instrument employed in the IV regressions is the expected proportion of 16- and 17-year-olds interacted with a dummy $=1$ for years 2008 to 2012. Int_x is a vector consisting of the expected proportion of people aged $x,(x=10,15,20,40$ and $60)$ and its interaction with that dummy. ${ }^{*}, * *$, and $* * *$ indicate significance at the $10 \%, 5 \%$ and $1 \%$ levels, respectively.

\subsection{Conclusion}

In this chapter, we explore the hypothesis that vote-buying practices may be sustained by politicians through targeting voters affiliated to their parties. Using data on Brazilian municipalities, we find that voters affiliated to parties in the Workers' Party municipal coalitions are more likely to start receiving benefits from the Bolsa Familia CCT program when candidates running under those coalitions are elected (and thus endowed with the power to identify beneficiaries). On the other hand, voters affiliated to other parties appear not to be especially targeted with the corresponding benefits upon local incumbency by such coalitions. In light of the evidence on the importance of voter affiliation status for politicians in determining whose votes to attempt to buy, we also investigate the extent to which the promotion of new affiliations is influenced by factors under the control of local incumbents. We then see that while local incumbency alone does not seem to broadly impact affiliation levels, the provision of Bolsa Familia payments shows a robust and significant effect on affiliation levels overall. Hence, politicians willing to foster voter affiliation to their parties may have to appeal to discretionary policies rather than solely count on the perquisites of officeholding.

Our main results present important policy implications. First, they provide empirical support to the growing body of evidence on the corrupt conduct of social programs due 
to the ability of incumbents to strategically use loopholes in these programs' operational rules. In that sense, our findings reinforce the need for an adequate design of such rules and indicate that, in the specific case of the Bolsa Familia, a proper (or, at least, better) conduct of the program would possibly require that the identification of beneficiaries be made by nonpartisan agencies. In addition, since our results shed light on specific political agents among which clientelistic practices are more likely to be implemented, they may be used to guide investigations and to focus efforts directed at restraining that kind of activity.

However, the lack of suitable data constrains the elucidation of closely related questions. In particular, it is still not clear whether new affiliations that come as a result of receiving Bolsa Familia benefits have an explicit clientelistic motivation (by voters) or instead simply consist of honest manifestations of support regarding the conduct of that program. Similarly, it would be interesting to assess what kind of specific behavior (ultimately leading to a favorable vote-casting) by voters is being contracted for or expected by politicians in affiliation-based clientelistic exchanges. Some alternatives would be that they grant benefits in order to influence voters' political preferences, or rather that they actually have a good knowledge of voters' preferences and are only paying them to turn out to vote. ${ }^{32}$ In addition, politicians may engage in clientelistic activities not only to secure the votes of their clients but also to incentivize them to deliver favorable votes from individuals in their social networks. ${ }^{33}$ The assessment of such questions could provide important insights into the adequacy of basic assumptions underlying standard voting models and is left for future research.

\section{References for Chapter 2}

Alesina, Alberto and Paola Giuliano (2011). "Family Ties and Political Participation". Journal of the European Economic Association, 9(5), pp. 817-839.

Banfield, Edward C. (1967). The Moral Basis of a Backward Society. New York: Free Press.

Bardhan, Pranab and Dilip Mookherjee (2012). "Political Clientelism and Capture: Theory and Evidence from West Bengal, India". UNU-WIDER Research Paper.

Baron, David P. (1994). "Electoral Competition with Informed and Uninformed Voters." American Political Science Review, 88(1), pp. 33-47.

\footnotetext{
${ }^{32}$ The latter alternative is less likely to be true in the Brazilian context, however, given the mandatory character of voting.

${ }^{33}$ The next chapter discusses a specific case whereby affiliated voters may influence other individuals' voting behavior.
} 
Bartels, Larry M. (2000). "Partisanship and Voting Behavior, 1952-1996". American Journal of Political Science, 44(1), pp. 35-50.

- (2002). "Beyond the Running Tally: Partisan Bias in Political Perceptions". Political Behavior, 24(2), pp. 117-150.

Besley, Timothy (2006). Principled Agents?: The Political Economy of Good Government. Oxford University Press.

Besley, Timothy and Robin Burgess (2002). "The Political Economy Of Government Responsiveness: Theory And Evidence From India". The Quarterly Journal of Economics, 117(4), pp. 1415-1451.

Campbell, Angus, Philip Converse, Warren Miller, and Donald Stokes (1960). The American Voter. New York: Wiley.

Converse, Philip E. (1969). "Of Time and Partisan Stability". Comparative Political Studies, 2(2), pp. 139-171.

Converse, Philip E. and Georges Dupeux (1962). "Politicization of the Electorate in France and the United States". Public Opinion Quarterly, 26(1), pp. 1-23.

Ferejohn, John (1986). "Incumbent Performance and Electoral Control". Public Choice, 50(1), pp. 5-25.

Finan, Frederico and Laura Schechter (2012). "Vote-Buying and Reciprocity". Econometrica, 80(2), pp. 863-881.

Gerber, Alan S. and Gregory A. Huber (2010). "Partisanship, Political Control, and Economic Assessments". American Journal of Political Science, 54(1), pp. 153-173.

Gerber, Alan S., Gregory A. Huber, and Ebonya Washington (2010). "Party Affiliation, Partisanship, and Political Beliefs: A Field Experiment". American Political Science Review, 104(4), pp. 720-744.

Glaeser, Edward, Giacomo Ponzetto, and Andrei Shleifer (2007). "Why Does Democracy Need Education?" Journal of Economic Growth, 12(2), pp. 77-99.

Glewwe, Paul and Ana Lucia Kassouf (2012). "The Impact of the Bolsa Escola/Família Conditional Cash Transfer Program on Enrollment, Dropout Rates and Grade Promotion in Brazil". Journal of Development Economics, 97(2), pp. 505-517.

Grossman, Gene M. and Elhanan Helpman (1996). "Electoral Competition and Special Interest Politics". The Review of Economic Studies, 63(2), pp. 265-286.

- (1999). "Competing for Endorsements". American Economic Review, 89(3), pp. 501524.

Guiso, Luigi, Paola Sapienza, and Luigi Zingales (2004). "The Role of Social Capital in Financial Development". American Economic Review, 94(3), pp. 526-556.

Hicken, Allen (2011). "Clientelism". Annual Review of Political Science, 14, pp. 289-310. Hillygus, D. Sunshine (2005). "The Missing Link: Exploring the Relationship between Higher Education and Political Engagement". Political Behavior, 27(1), pp. 25-47. 
Imbens, Guido W. and Karthik Kalyanaraman (2012). "Optimal Bandwidth Choice for the Regression Discontinuity Estimator". Review of Economic Studies, 79(3), pp. 933959.

Imbens, Guido W. and Thomas Lemieux (2008). "Regression Discontinuity Designs: A Guide to Practice". Journal of Econometrics, 142(2), pp. 615-635.

Keefer, Philip (2007). "Clientelism, Credibility, and the Policy Choices of Young Democracies". American Journal of Political Science, 51(4), pp. 804-821.

Kitschelt, Herbert and Steven I. Wilkinson (2007). Patrons, Clients and Policies: Patterns of Democratic Accountability and Political Competition. Cambridge University Press.

Larreguy, Horacio (2013). "Monitoring Political Brokers: Evidence from Clientelistic Networks in México". Working Paper.

Lee, David S. (2008). "Randomized experiments from non-random selection in U.S. House elections". Journal of Econometrics, 142(2), pp. 675-697.

Lizzeri, Alessandro and Nicola Persico (2001). "The Provision of Public Goods under Alternative Electoral Incentives". American Economic Review, 91(1), pp. 225-239.

McCrary, Justin (2008). "Manipulation of the running variable in the regression discontinuity design: A density test". Journal of Econometrics, 142(2), pp. 698-714.

Milligan, Kevin, Enrico Moretti, and Philip Oreopoulos (2004). "Does Education Improve Citizenship? Evidence from the United States and the United Kingdom". Journal of Public Economics, 88(9), pp. 1667-1695.

Nie, Norman, Jane Junn, and Ken Stehlik-Barry (1996). Education and Citizenship in America. Chicago: Cambridge University Press.

Persson, Mikael (2014). "Testing the Relationship Between Education and Political Participation Using the 1970 British Cohort Study". Political Behavior, 36(4), pp. 877897.

Persson, Torsten and Guido Enrico Tabellini (2002). Political Economics: Explaining Economic Policy. MIT press.

Robinson, James A. and Thierry Verdier (2013). "The Political Economy of Clientelism". The Scandinavian Journal of Economics, 115(2), pp. 260-291.

Soares, Sergei and Natália Sátyro (2009). "O Programa Bolsa Família: Desenho Institucional, Impactos e Possibilidades Futuras". Texto para Discussão 1424 - IPEA.

Solis, Alex (2014). "Does higher education cause political participation? Evidence from a regression discontinuity design". Working Paper.

Stokes, Susan C. (2005). "Perverse Accountability: A Formal Model of Machine Politics with Evidence from Argentina". American Political Science Review, 99(3), pp. 315325 .

Wolfinger, Raymond E. and Steven J. Rosenstone (1980). Who votes? New Haven: Yale University Press. 


\section{Appendices to Chapter 2}

\section{A Additional Figures}

Figure 2.A1: McCrary Test - Distribution of Vote Share Margins, 2008-2012 elections

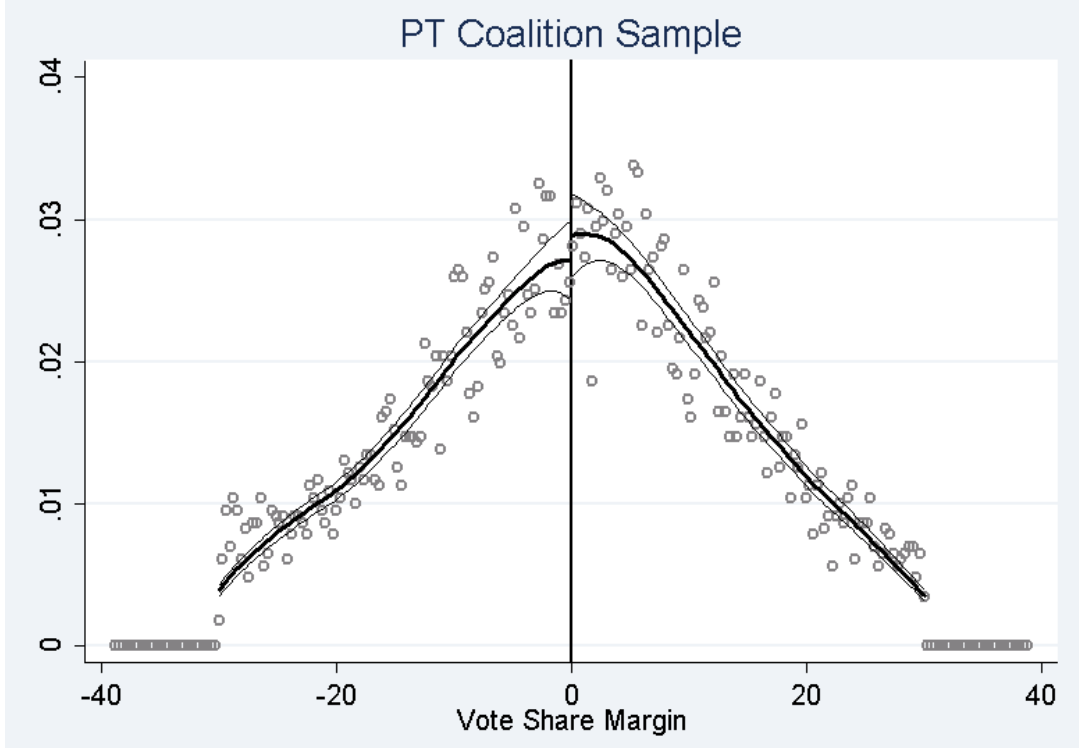

This figure is based on McCrary (2008) and derived from data on the municipal elections of 20082012. Solid thick lines represent estimates of the densities of vote share margins in each sample, and $95 \%$ confidence intervals are denoted by thin lines. 
Figure 2.A2: Shares of Affiliates among New Beneficiaries
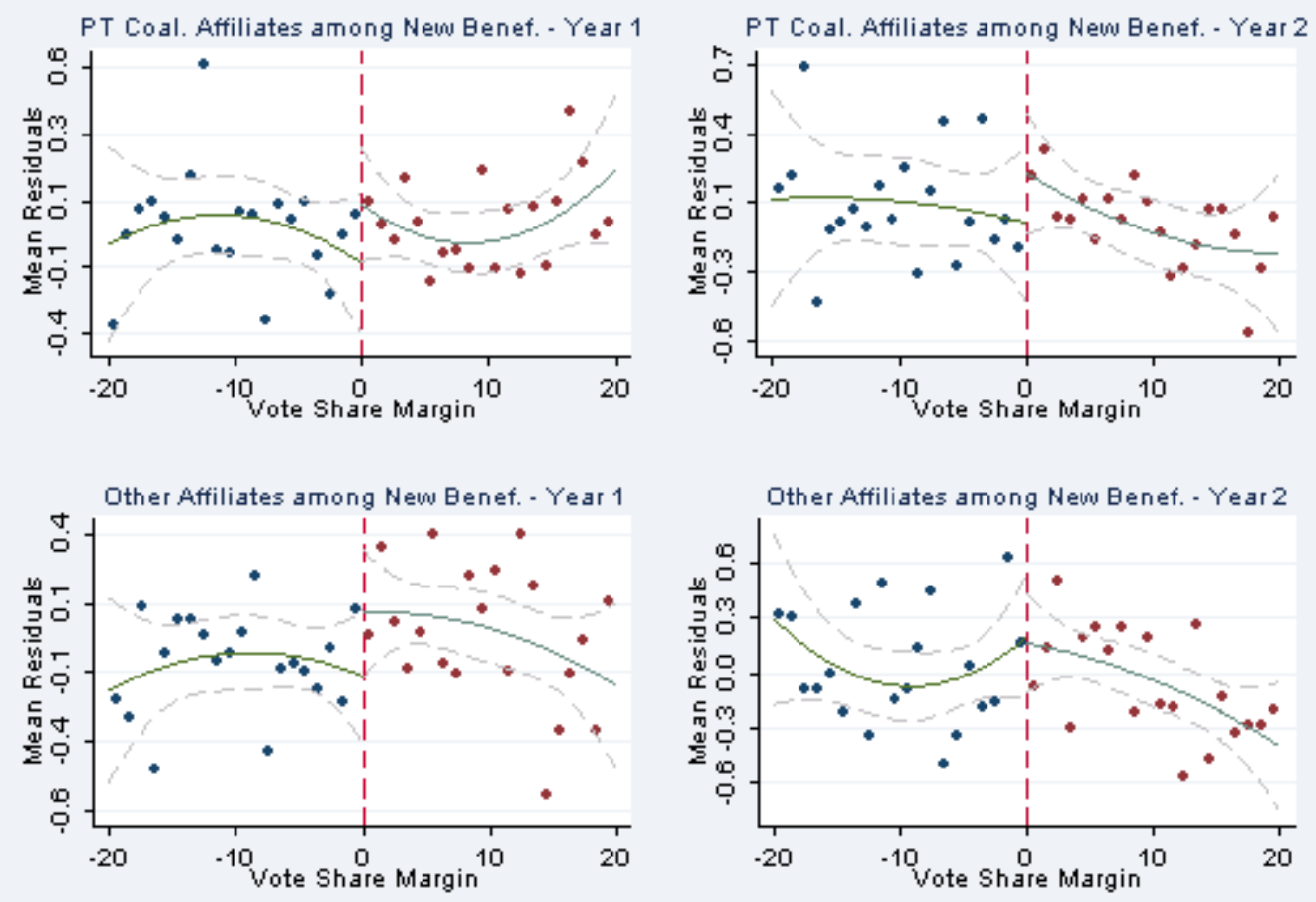

The graphs plot averages of the residuals of regressions on the controls-listed in Table 2.B1 of the share of voters affiliated (as of the election year) to the PT coalition and, alternatively, to other parties among individuals who start receiving Bolsa Familia benefits in each of the two years following election. The data is obtained by pooling the municipal elections of 2008-2012. Each point is the average of residuals within $1 \%$ intervals of vote share margin. Solid lines are fitted values of quadratic polynomial regressions on each side of the discontinuity and dashed lines represent $95 \%$ confidence intervals. 
Figure 2.A3: McCrary Test - Distribution of Vote Share Margins, 1996-2008 elections
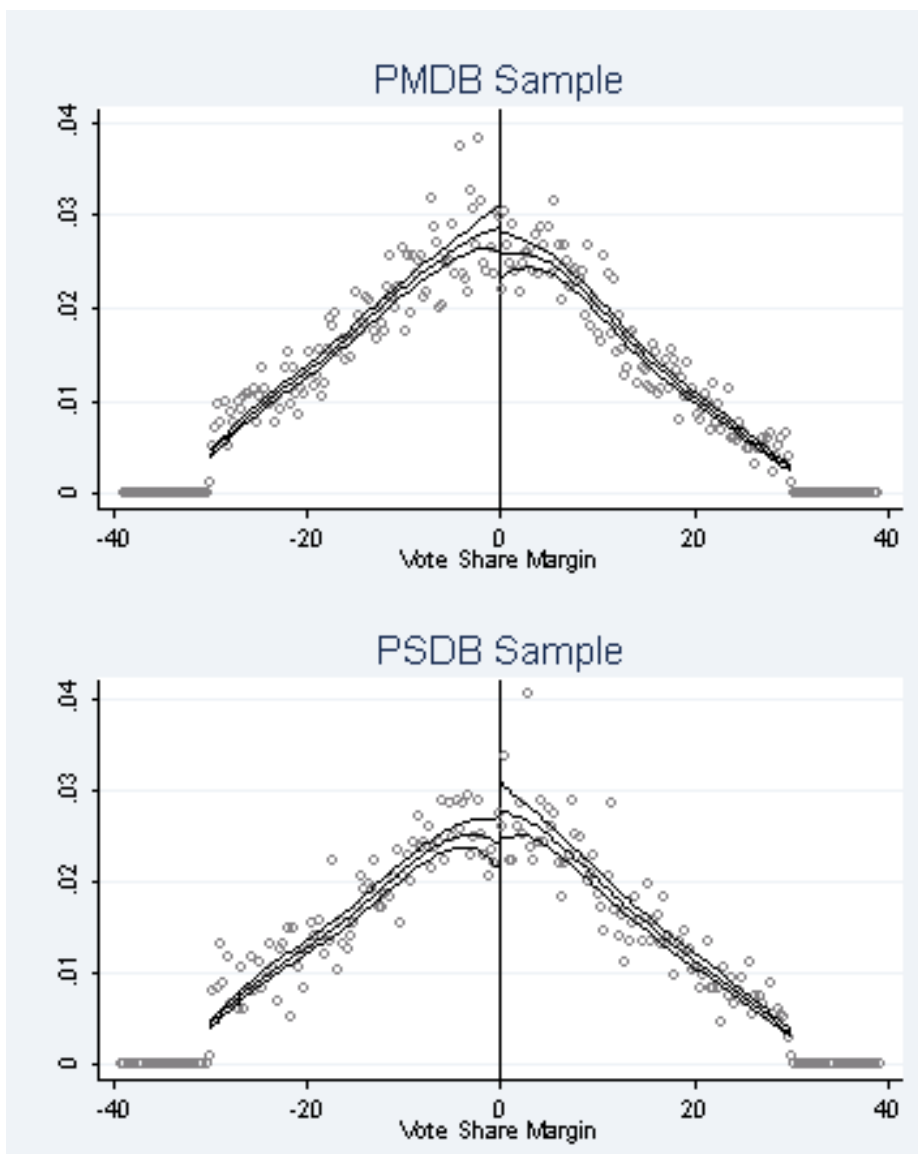

PT Sample

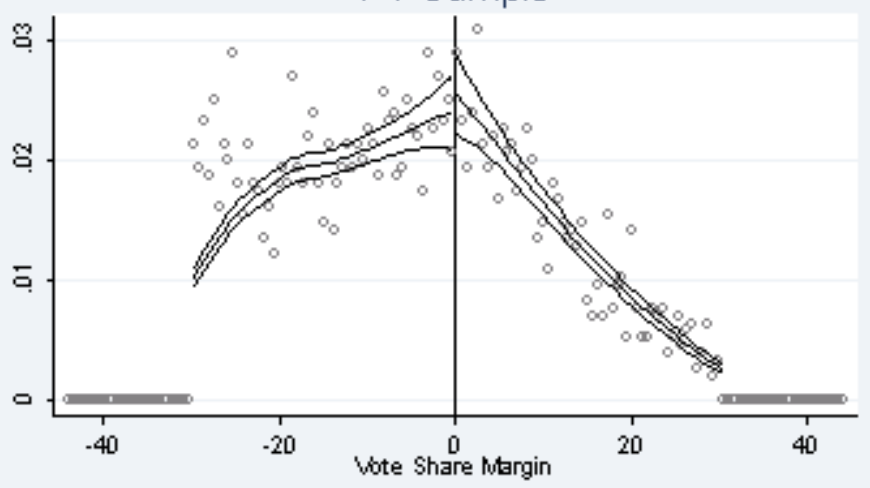

This figure is based on McCrary (2008) and derived from data on the municipal elections of 19962008. Solid thick lines represent estimates of the densities of vote share margins in each sample, and $95 \%$ confidence intervals are denoted by thin lines. 
Figure 2.A4: Electorate Becoming Affiliated (\%), by Party
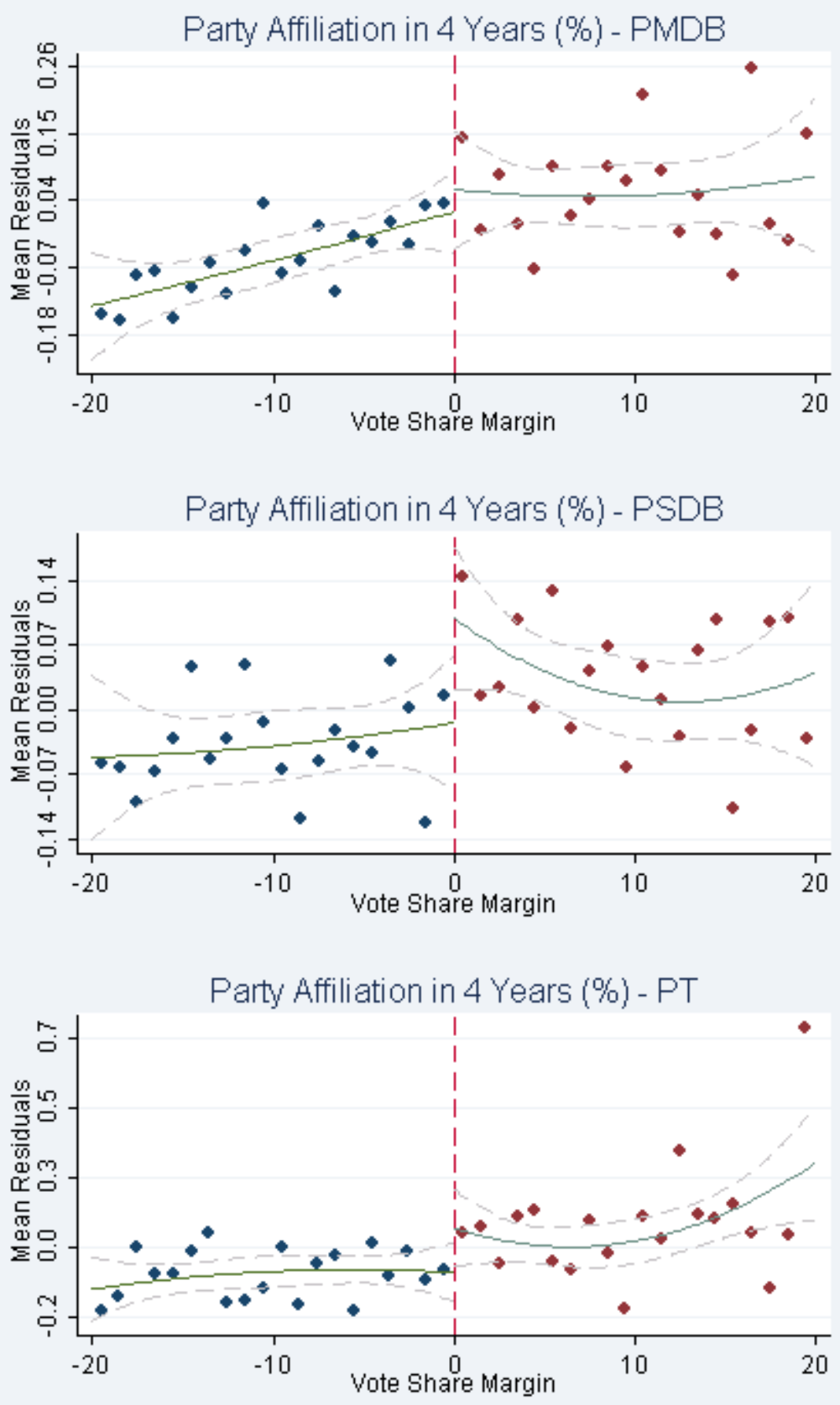

Each graph plots averages of the residuals of a regression of the percentage of the electorate registering for affiliation to each party in the next four years on the controls-listed in Table 2.B4 -against the margin of victory of the corresponding party, pooling municipal elections from 1996 to 2008. Each point is the average of residuals within $1 \%$ intervals of vote share margin. Solid lines are fitted values of quadratic polynomial regressions on each side of the discontinuity and dashed lines represent $95 \%$ confidence intervals. 


\section{B Additional Tables}

Table 2.B1: Summary Statistics for 2008-2012 Municipal Elections - PT Coalition Samples

\begin{tabular}{|c|c|c|c|}
\hline Variable & Observations & Mean & $\begin{array}{l}\text { Standard } \\
\text { Deviation }\end{array}$ \\
\hline $\begin{array}{l}\text { Affiliated to PT Coal. among } \\
\text { New Beneficiaries in Year } 1(\%)\end{array}$ & 9,257 & 2.027 & 2.626 \\
\hline $\begin{array}{l}\text { Affiliated to PT Coal. among } \\
\text { New Beneficiaries in Year } 2(\%)\end{array}$ & 9,257 & 2.040 & 3.344 \\
\hline $\begin{array}{l}\text { Other Affiliates among } \\
\text { New Beneficiaries in Year } 1(\%)\end{array}$ & 9,257 & 3.278 & 3.030 \\
\hline $\begin{array}{l}\text { Other Affiliates among } \\
\text { New Beneficiaries in Year } 2(\%)\end{array}$ & 9,257 & 3.191 & 3.529 \\
\hline Population (log) & 9,257 & 9.447 & 1.043 \\
\hline Per Capita Monthly Income & 9,257 & 208.8 & 117.0 \\
\hline Party State Governor & 9,257 & 0.181 & 0.385 \\
\hline Literacy among $15+$ Year-olds (\%) & 9,257 & 80.95 & 11.05 \\
\hline Individuals w/ College Degree (\%) & 9,257 & 3.850 & 3.095 \\
\hline Number of Candidates & 9,257 & 2.737 & 0.980 \\
\hline Log Munic. Area $\left(\mathrm{km}^{2}\right)$ & 9,257 & 6.276 & 1.286 \\
\hline Beneficiaries (\%) & 9,257 & 9.978 & 4.928 \\
\hline Urban Population (\%) & 9,257 & 63.03 & 22.01 \\
\hline PT Coalition in Reelection Bid & 9,257 & 0.204 & 0.204 \\
\hline Affiliated to PT Coalition (\%) & 9,257 & 4.753 & 3.773 \\
\hline Affiliated to Other Parties (\%) & 9,257 & 7.618 & 4.431 \\
\hline
\end{tabular}

The unit of observation is a year-municipality, pooling election years from 2008 to 2012 (two cycles). The sample is restricted to municipalities/elections in which the PT either ran for office or was part of a coalition. 
Table 2.B2: BF Targeting to Affiliated Voters - Validity Checks, by Population Size $(1 / 2)$

\begin{tabular}{|c|c|c|c|c|c|}
\hline & $\begin{array}{l}\text { IKBW } \\
\{\text { obs }\}\end{array}$ & (1) & $(2)$ & (3) & $(4)$ \\
\hline \multicolumn{6}{|c|}{ Tests of Quasi-Random Assignment } \\
\hline \multicolumn{6}{|c|}{ Municipalities with Below-Median Population } \\
\hline Population $(\log )$ & $\begin{array}{l}1.94 \% \\
\{368\}\end{array}$ & $\begin{array}{c}0.0627 \\
(0.0984)\end{array}$ & $\begin{array}{c}0.0304 \\
(0.0420)\end{array}$ & $\begin{array}{c}0.0479 \\
(0.0596)\end{array}$ & $\begin{array}{l}0.0550 \\
(0.145)\end{array}$ \\
\hline $\begin{array}{l}\text { Per Capita Monthly } \\
\text { Income }\end{array}$ & $\begin{array}{l}10.55 \% \\
\{1,941\}\end{array}$ & $\begin{array}{l}-4.592 \\
(6.397)\end{array}$ & $\begin{array}{l}-4.747 \\
(6.482)\end{array}$ & $\begin{array}{l}-12.90 \\
(8.739)\end{array}$ & $\begin{array}{l}-9.117 \\
(21.86)\end{array}$ \\
\hline Party State Governor & $\begin{array}{l}1.57 \% \\
\{299\}\end{array}$ & $\begin{array}{c}0.100 \\
(0.101)\end{array}$ & $\begin{array}{l}-0.0320 \\
(0.0331)\end{array}$ & $\begin{array}{l}-0.00245 \\
(0.0484)\end{array}$ & $\begin{array}{r}0.294^{* *} \\
(0.138)\end{array}$ \\
\hline $\begin{array}{l}\text { Literacy among } 15+ \\
\text { y.o. (\%) }\end{array}$ & $\begin{array}{l}4.67 \% \\
\{919\}\end{array}$ & $\begin{array}{l}-0.196 \\
(0.710)\end{array}$ & $\begin{array}{l}-0.371 \\
(0.500)\end{array}$ & $\begin{array}{r}-0.0867 \\
(0.675)\end{array}$ & $\begin{array}{l}-1.499 \\
(1.779)\end{array}$ \\
\hline $\begin{array}{l}\text { Individuals w/ } \\
\text { college degree (\%) }\end{array}$ & $\begin{array}{l}3.34 \% \\
\{664\}\end{array}$ & $\begin{array}{l}-0.101 \\
(0.236)\end{array}$ & $\begin{array}{r}-0.0673 \\
(0.143)\end{array}$ & $\begin{array}{c}-0.0324 \\
(0.196)\end{array}$ & $\begin{array}{l}-0.686 \\
(0.452)\end{array}$ \\
\hline Number of Candidates & $\begin{array}{l}2.28 \% \\
\{452\}\end{array}$ & $\begin{array}{c}0.130 \\
(0.106)\end{array}$ & $\begin{array}{c}0.0223 \\
(0.0512)\end{array}$ & $\begin{array}{c}0.0268 \\
(0.0693)\end{array}$ & $\begin{array}{l}0.0860 \\
(0.172)\end{array}$ \\
\hline $\begin{array}{l}\text { Log Munic. Area } \\
\left(\mathrm{km}^{2}\right)\end{array}$ & $\begin{array}{l}2.55 \% \\
\{506\}\end{array}$ & $\begin{array}{c}0.335^{* *} \\
(0.137)\end{array}$ & $\begin{array}{c}0.0775 \\
(0.0704)\end{array}$ & $\begin{array}{c}0.141 \\
(0.0975)\end{array}$ & $\begin{array}{r}-0.0115 \\
(0.239)\end{array}$ \\
\hline Beneficiaries (\%) & $\begin{array}{l}4.30 \% \\
\{856\}\end{array}$ & $\begin{array}{c}0.537 \\
(0.411)\end{array}$ & $\begin{array}{c}0.223 \\
(0.266)\end{array}$ & $\begin{array}{c}0.583 \\
(0.374)\end{array}$ & $\begin{array}{c}1.250 \\
(1.074)\end{array}$ \\
\hline Urban Population (\%) & $\begin{array}{c}5.05 \% \\
\{1,000\}\end{array}$ & $\begin{array}{l}-2.652 \\
(2.235)\end{array}$ & $\begin{array}{c}-3.005^{*} \\
(1.562)\end{array}$ & $\begin{array}{l}-2.833 \\
(2.238)\end{array}$ & $\begin{array}{l}-4.890 \\
(6.514)\end{array}$ \\
\hline $\begin{array}{l}\text { PT Coalition in } \\
\text { Reelection Bid }\end{array}$ & $\begin{array}{l}1.87 \% \\
\{353\}\end{array}$ & $\begin{array}{c}-0.102 \\
(0.0922)\end{array}$ & $\begin{array}{c}-0.0314 \\
(0.0382)\end{array}$ & $\begin{array}{l}-0.0206 \\
(0.0544)\end{array}$ & $\begin{array}{l}-0.102 \\
(0.124)\end{array}$ \\
\hline $\begin{array}{l}\text { Affiliated to PT } \\
\text { Coalition }(\%)\end{array}$ & $\begin{array}{l}3.40 \% \\
\{683\}\end{array}$ & $\begin{array}{l}-1.062^{*} \\
(0.612)\end{array}$ & $\begin{array}{l}-0.308 \\
(0.348)\end{array}$ & $\begin{array}{l}-0.702 \\
(0.489)\end{array}$ & $\begin{array}{l}-1.022 \\
(1.266)\end{array}$ \\
\hline $\begin{array}{l}\text { Affiliated to } \\
\text { Other Parties (\%) }\end{array}$ & $\begin{array}{l}4.34 \% \\
\{861\}\end{array}$ & $\begin{array}{l}-0.911 \\
(0.614)\end{array}$ & $\begin{array}{l}-0.404 \\
(0.393)\end{array}$ & $\begin{array}{l}-0.691 \\
(0.579)\end{array}$ & $\begin{array}{l}-0.402 \\
(1.374)\end{array}$ \\
\hline Bandwidth & & IKBW & $10 \%$ & $5 \%$ & $1 \%$ \\
\hline Observations & & - & 1,860 & 994 & 185 \\
\hline
\end{tabular}

All notes to Table 2.2 apply. 
Table 2.B3: BF Targeting to Affiliated Voters - Validity Checks, by Population Size $(2 / 2)$

\begin{tabular}{|c|c|c|c|c|c|}
\hline & $\begin{array}{l}\text { IKBW } \\
\{\text { obs }\}\end{array}$ & $(1)$ & $(2)$ & $(3)$ & $(4)$ \\
\hline \multicolumn{6}{|c|}{ Tests of Quasi-Random Assignment } \\
\hline \multicolumn{6}{|c|}{ Municipalities with Above-Median Population } \\
\hline Population (log) & $\begin{array}{l}2.58 \% \\
\{501\}\end{array}$ & $\begin{array}{c}-0.181^{*} \\
(0.106)\end{array}$ & $\begin{array}{l}-0.0936 \\
(0.0572)\end{array}$ & $\begin{array}{c}-0.161^{* *} \\
(0.0778)\end{array}$ & $\begin{array}{l}-0.204 \\
(0.181)\end{array}$ \\
\hline $\begin{array}{l}\text { Per Capita Monthly } \\
\text { Income }\end{array}$ & $\begin{array}{c}9.83 \% \\
\{1,799\}\end{array}$ & $\begin{array}{l}-5.473 \\
(5.872)\end{array}$ & $\begin{array}{l}-5.645 \\
(5.824)\end{array}$ & $\begin{array}{l}-9.749 \\
(8.691)\end{array}$ & $\begin{array}{l}-1.484 \\
(17.15)\end{array}$ \\
\hline Party State Governor & $\begin{array}{l}2.08 \% \\
\{389\}\end{array}$ & $\begin{array}{l}-0.140^{*} \\
(0.0831)\end{array}$ & $\begin{array}{l}-0.0340 \\
(0.0367)\end{array}$ & $\begin{array}{l}-0.0429 \\
(0.0529)\end{array}$ & $\begin{array}{l}-0.143 \\
(0.125)\end{array}$ \\
\hline $\begin{array}{l}\text { Literacy among } 15+ \\
\text { y.o. (\%) }\end{array}$ & $\begin{array}{c}5.68 \% \\
\{1,096\}\end{array}$ & $\begin{array}{l}-0.273 \\
(0.752)\end{array}$ & $\begin{array}{l}-0.497 \\
(0.580)\end{array}$ & $\begin{array}{l}0.0838 \\
(0.814)\end{array}$ & $\begin{array}{c}0.983 \\
(1.888)\end{array}$ \\
\hline $\begin{array}{l}\text { Individuals w/ } \\
\text { College Degree (\%) }\end{array}$ & $\begin{array}{l}3.74 \% \\
\{726\}\end{array}$ & $\begin{array}{c}0.136 \\
(0.305)\end{array}$ & $\begin{array}{l}-0.0887 \\
(0.181)\end{array}$ & $\begin{array}{l}-0.109 \\
(0.263)\end{array}$ & $\begin{array}{c}0.457 \\
(0.626)\end{array}$ \\
\hline Number of Candidates & $\begin{array}{l}2.93 \% \\
\{582\}\end{array}$ & $\begin{array}{l}0.0965 \\
(0.173)\end{array}$ & $\begin{array}{r}-0.00308 \\
(0.0922)\end{array}$ & $\begin{array}{c}-0.00109 \\
(0.132)\end{array}$ & $\begin{array}{l}0.0153 \\
(0.284)\end{array}$ \\
\hline $\begin{array}{l}\text { Log Munic. Area } \\
\left(\mathrm{km}^{2}\right)\end{array}$ & $\begin{array}{l}2.37 \% \\
\{446\}\end{array}$ & $\begin{array}{c}-0.368^{* *} \\
(0.173)\end{array}$ & $\begin{array}{l}-0.0330 \\
(0.0902)\end{array}$ & $\begin{array}{r}-0.0772 \\
(0.123)\end{array}$ & $\begin{array}{c}-0.637^{* *} \\
(0.271)\end{array}$ \\
\hline Beneficiaries (\%) & $\begin{array}{l}4.52 \% \\
\{891\}\end{array}$ & $\begin{array}{l}0.0189 \\
(0.324)\end{array}$ & $\begin{array}{c}-0.0434 \\
(0.224)\end{array}$ & $\begin{array}{c}0.141 \\
(0.305)\end{array}$ & $\begin{array}{c}0.646 \\
(0.650)\end{array}$ \\
\hline Urban Population (\%) & $\begin{array}{c}6.88 \% \\
\{1,320\}\end{array}$ & $\begin{array}{l}-1.779 \\
(1.933)\end{array}$ & $\begin{array}{l}-0.923 \\
(1.597)\end{array}$ & $\begin{array}{l}-1.559 \\
(2.306)\end{array}$ & $\begin{array}{l}2.985 \\
(5.787)\end{array}$ \\
\hline $\begin{array}{l}\text { PT Coalition in } \\
\text { Reelection Bid }\end{array}$ & $\begin{array}{l}2.22 \% \\
\{418\}\end{array}$ & $\begin{array}{l}-0.0530 \\
(0.0876)\end{array}$ & $\begin{array}{l}-0.00817 \\
(0.0365)\end{array}$ & $\begin{array}{l}-0.00964 \\
(0.0541)\end{array}$ & $\begin{array}{r}-0.0339 \\
(0.139)\end{array}$ \\
\hline $\begin{array}{l}\text { Affiliated to PT } \\
\text { Coalition (\%) }\end{array}$ & $\begin{array}{l}3.23 \% \\
\{641\}\end{array}$ & $\begin{array}{c}0.248 \\
(0.279)\end{array}$ & $\begin{array}{c}-0.00191 \\
(0.159)\end{array}$ & $\begin{array}{l}0.0414 \\
(0.227)\end{array}$ & $\begin{array}{c}0.722 \\
(0.515)\end{array}$ \\
\hline $\begin{array}{l}\text { Affiliated to } \\
\text { Other Parties (\%) }\end{array}$ & $\begin{array}{l}3.30 \% \\
\{649\}\end{array}$ & $\begin{array}{c}0.357 \\
(0.331)\end{array}$ & $\begin{array}{l}-0.153 \\
(0.192)\end{array}$ & $\begin{array}{c}0.102 \\
(0.266)\end{array}$ & $\begin{array}{c}0.247 \\
(0.585)\end{array}$ \\
\hline Bandwidth & & IKBW & $10 \%$ & $5 \%$ & $1 \%$ \\
\hline Observations & & - & 1,821 & 972 & 197 \\
\hline
\end{tabular}

All notes to Table 2.2 apply. 
Table 2.B4: Summary Statistics for 1996-2008 Election Samples

\begin{tabular}{|c|c|c|c|}
\hline \multirow{3}{*}{ Variable } & \multicolumn{3}{|c|}{ Mean [Std. Deviation] } \\
\hline & PMDB & PSDB & $\mathrm{PT}$ \\
\hline & Sample & Sample & Sample \\
\hline \multirow[t]{2}{*}{ Affiliated in the Next 4 Years (\%) } & 0.490 & 0.330 & 0.322 \\
\hline & {$[1.026]$} & {$[0.717]$} & {$[0.599]$} \\
\hline \multirow[t]{2}{*}{ Party Affiliates (\%) } & 3.005 & 1.615 & 1.245 \\
\hline & {$[2.890]$} & {$[1.585]$} & {$[1.158]$} \\
\hline \multirow[t]{2}{*}{ Affiliated in the Last Year (\%) } & 0.046 & 0.027 & 0.062 \\
\hline & {$[0.228]$} & {$[0.254]$} & {$[0.188]$} \\
\hline \multirow{2}{*}{ Population (log) } & 9.338 & 9.464 & 9.778 \\
\hline & {$[1.077]$} & {$[1.124]$} & {$[1.189]$} \\
\hline \multirow[t]{2}{*}{ Per Capita Monthly Income } & 166.3 & 167.6 & 186.0 \\
\hline & [94.40] & {$[98.76]$} & {$[103.3]$} \\
\hline \multirow[t]{2}{*}{ Party State Governor } & 0.341 & 0.558 & 0.138 \\
\hline & {$[0.474]$} & {$[0.497]$} & {$[0.345]$} \\
\hline \multirow[t]{2}{*}{ Literacy among $15+$ Year-olds (\%) } & 78.24 & 77.34 & 80.75 \\
\hline & {$[13.52]$} & {$[13.54]$} & {$[12.45]$} \\
\hline \multirow[t]{2}{*}{ Number of Candidates } & 2.832 & 2.976 & 3.329 \\
\hline & {$[1.086]$} & {$[1.166]$} & {$[1.167]$} \\
\hline \multirow[t]{2}{*}{ Log Munic. Area $\left(\mathrm{km}^{2}\right)$} & 6.200 & 6.250 & 6.343 \\
\hline & {$[1.292]$} & {$[1.283]$} & {$[1.327]$} \\
\hline Observations & 10,411 & 7,574 & 5,736 \\
\hline
\end{tabular}

The unit of observation is a year-municipality, pooling election years from 1996 to 2008 (four cycles). Each party sample refers to municipalities in which the corresponding party ran for office. Shares of affiliated voters refer to affiliation to the given party. 
Table 2.B5: Incumbency Effects on Voter Affiliation - Validity Checks - PMDB

\begin{tabular}{|c|c|c|c|c|c|}
\hline & $\begin{array}{c}\text { IKBW } \\
\{\mathrm{obs}\}\end{array}$ & $(1)$ & $(2)$ & $(3)$ & $(4)$ \\
\hline \multicolumn{6}{|c|}{ Tests of Quasi-Random Assignment (Effects on Pre-Determined Covariates) } \\
\hline Party Affiliates (\%) & $\begin{array}{c}3.17 \% \\
\{1,458\}\end{array}$ & $\begin{array}{l}0.0387 \\
(0.291)\end{array}$ & $\begin{array}{r}-0.0333 \\
(0.155)\end{array}$ & $\begin{array}{r}-0.0297 \\
(0.222)\end{array}$ & $\begin{array}{c}-0.0573 \\
(0.553)\end{array}$ \\
\hline $\begin{array}{l}\text { Affiliated in the Last } \\
\text { Year }(\%)\end{array}$ & $\begin{array}{l}1.48 \% \\
\{669\}\end{array}$ & $\begin{array}{l}-0.0210 \\
(0.0277)\end{array}$ & $\begin{array}{c}0.0369^{* * *} \\
(0.0131)\end{array}$ & $\begin{array}{l}0.00197 \\
(0.0171)\end{array}$ & $\begin{array}{l}0.00413 \\
(0.0345)\end{array}$ \\
\hline Population (log) & $\begin{array}{l}2.20 \% \\
\{991\}\end{array}$ & $\begin{array}{c}-0.0474 \\
(0.119)\end{array}$ & $\begin{array}{l}-0.0378 \\
(0.0551)\end{array}$ & $\begin{array}{r}-0.00516 \\
(0.0786)\end{array}$ & $\begin{array}{r}-0.0927 \\
(0.182)\end{array}$ \\
\hline $\begin{array}{l}\text { Per Capita Monthly } \\
\text { Income }\end{array}$ & $\begin{array}{c}7.39 \% \\
\{3,309\}\end{array}$ & $\begin{array}{l}-2.447 \\
(4.423)\end{array}$ & $\begin{array}{l}-1.373 \\
(3.857)\end{array}$ & $\begin{array}{l}-8.962^{*} \\
(5.338)\end{array}$ & $\begin{array}{l}-13.73 \\
(10.61)\end{array}$ \\
\hline Party State Governor & $\begin{array}{l}1.97 \% \\
\{876\}\end{array}$ & $\begin{array}{l}-0.0815 \\
(0.0557)\end{array}$ & $\begin{array}{l}-0.0129 \\
(0.0246)\end{array}$ & $\begin{array}{l}-0.0423 \\
(0.0345)\end{array}$ & $\begin{array}{l}-0.0383 \\
(0.0810)\end{array}$ \\
\hline $\begin{array}{l}\text { Literacy among } 15+ \\
\text { y.o. }(\%)\end{array}$ & $\begin{array}{c}5.33 \% \\
\{2,423\}\end{array}$ & $\begin{array}{c}0.333 \\
(0.556)\end{array}$ & $\begin{array}{c}0.253 \\
(0.402)\end{array}$ & $\begin{array}{c}0.415 \\
(0.579)\end{array}$ & $\begin{array}{l}-0.786 \\
(1.451)\end{array}$ \\
\hline Number of Candidates & $\begin{array}{l}2.24 \% \\
\{1,005\}\end{array}$ & $\begin{array}{c}-0.0364 \\
(0.112)\end{array}$ & $\begin{array}{l}-0.0220 \\
(0.0551)\end{array}$ & $\begin{array}{l}-0.0677 \\
(0.0755)\end{array}$ & $\begin{array}{l}-0.238 \\
(0.177)\end{array}$ \\
\hline $\begin{array}{l}\text { Log Munic. Area } \\
\left(\mathrm{km}^{2}\right)\end{array}$ & $\begin{array}{c}2.69 \% \\
\{1,223\}\end{array}$ & $\begin{array}{c}-0.0600 \\
(0.111)\end{array}$ & $\begin{array}{l}-0.0304 \\
(0.0550)\end{array}$ & $\begin{array}{c}0.00446 \\
(0.0790)\end{array}$ & $\begin{array}{c}0.0521 \\
(0.186)\end{array}$ \\
\hline $\begin{array}{l}\text { Bandwidth } \\
\text { Observations }\end{array}$ & & $\underset{-}{\mathrm{IKBW}}$ & $\begin{array}{c}10 \% \\
4,313\end{array}$ & $\begin{array}{c}5 \% \\
2,282\end{array}$ & $\begin{array}{l}1 \% \\
452\end{array}$ \\
\hline
\end{tabular}

Standard errors are robust to clustering at the municipality level. The unit of observation is a year-municipality, pooling municipal election years from 1996 to 2008. Each figure in columns (1)-(4) is from a separate local linear regression with the specified bandwidth. The IKBW column provides the optimal bandwidth according to Imbens and Kalyanaraman (2012) and the associated number of observations. Year dummies and state dummies are included as controls. $*, * *$, and ${ }^{* * *}$ indicate significance at the $10 \%, 5 \%$ and $1 \%$ levels, respectively. 
Table 2.B6: Incumbency Effects on Voter Affiliation - Validity Checks - PSDB

\begin{tabular}{|c|c|c|c|c|c|}
\hline & $\begin{array}{c}\text { IKBW } \\
\{\mathrm{obs}\}\end{array}$ & $(1)$ & $(2)$ & $(3)$ & $(4)$ \\
\hline \multicolumn{6}{|c|}{ Tests of Quasi-Random Assignment (Effects on Pre-Determined Covariates) } \\
\hline Party Affiliates (\%) & $\begin{array}{l}2.78 \% \\
\{841\}\end{array}$ & $\begin{array}{l}-0.0584 \\
(0.192)\end{array}$ & $\begin{array}{c}0.157 \\
(0.0991)\end{array}$ & $\begin{array}{l}0.0488 \\
(0.143)\end{array}$ & $\begin{array}{l}0.0627 \\
(0.276)\end{array}$ \\
\hline $\begin{array}{l}\text { Affiliated in the Last } \\
\text { Year }(\%)\end{array}$ & $\begin{array}{l}1.63 \% \\
\{475\}\end{array}$ & $\begin{array}{l}0.00146 \\
(0.0401)\end{array}$ & $\begin{array}{c}0.0172 \\
(0.0141)\end{array}$ & $\begin{array}{l}-0.00233 \\
(0.0228)\end{array}$ & $\begin{array}{c}0.0336 \\
(0.0592)\end{array}$ \\
\hline Population (log) & $\begin{array}{l}2.66 \% \\
\{794\}\end{array}$ & $\begin{array}{l}0.0455 \\
(0.136)\end{array}$ & $\begin{array}{c}0.0277 \\
(0.0726)\end{array}$ & $\begin{array}{c}0.107 \\
(0.0979)\end{array}$ & $\begin{array}{l}0.0694 \\
(0.231)\end{array}$ \\
\hline $\begin{array}{l}\text { Per Capita Monthly } \\
\text { Income }\end{array}$ & $\begin{array}{c}9.38 \% \\
\{2,775\}\end{array}$ & $\begin{array}{l}-5.567 \\
(4.583)\end{array}$ & $\begin{array}{l}-6.980 \\
(4.425)\end{array}$ & $\begin{array}{l}-5.292 \\
(6.034)\end{array}$ & $\begin{array}{c}6.255 \\
(13.61)\end{array}$ \\
\hline Party State Governor & $\begin{array}{l}1.99 \% \\
\{582\}\end{array}$ & $\begin{array}{l}-0.0296 \\
(0.0468)\end{array}$ & $\begin{array}{l}-0.0257 \\
(0.0216)\end{array}$ & $\begin{array}{l}-0.0186 \\
(0.0299)\end{array}$ & $\begin{array}{l}-0.0316 \\
(0.0738)\end{array}$ \\
\hline $\begin{array}{l}\text { Literacy among } 15+ \\
\text { y.o. }(\%)\end{array}$ & $\begin{array}{c}4.23 \% \\
\{1,294\}\end{array}$ & $\begin{array}{c}-0.0724 \\
(0.765)\end{array}$ & $\begin{array}{l}-0.235 \\
(0.498)\end{array}$ & $\begin{array}{c}0.486 \\
(0.702)\end{array}$ & $\begin{array}{l}-1.074 \\
(1.836)\end{array}$ \\
\hline Number of Candidates & $\begin{array}{l}2.68 \% \\
\{807\}\end{array}$ & $\begin{array}{c}-0.00433 \\
(0.145)\end{array}$ & $\begin{array}{c}0.0370 \\
(0.0756)\end{array}$ & $\begin{array}{l}0.0581 \\
(0.105)\end{array}$ & $\begin{array}{c}0.173 \\
(0.277)\end{array}$ \\
\hline $\begin{array}{l}\text { Log Munic. Area } \\
\left(\mathrm{km}^{2}\right)\end{array}$ & $\begin{array}{l}2.70 \% \\
\{812\}\end{array}$ & $\begin{array}{l}0.0188 \\
(0.136)\end{array}$ & $\begin{array}{c}0.105 \\
(0.0714)\end{array}$ & $\begin{array}{c}0.0956 \\
(0.0974)\end{array}$ & $\begin{array}{c}0.361 \\
(0.227)\end{array}$ \\
\hline $\begin{array}{l}\text { Bandwidth } \\
\text { Observations }\end{array}$ & & IKBW & $10 \%$ & $5 \%$ & $1 \%$ \\
\hline Observations & & - & 2,937 & 1,542 & 296 \\
\hline
\end{tabular}

See notes to Table 2.B5. 
Table 2.B7: Incumbency Effects on Voter Affiliation - Validity Checks - PT

\begin{tabular}{|c|c|c|c|c|c|}
\hline & $\begin{array}{c}\text { IKBW } \\
\{\text { obs }\}\end{array}$ & $(1)$ & $(2)$ & $(3)$ & $(4)$ \\
\hline \multicolumn{6}{|c|}{ Tests of Quasi-Random Assignment (Effects on Pre-Determined Covariates) } \\
\hline Party Affiliates (\%) & $\begin{array}{l}2.53 \% \\
\{333\}\end{array}$ & $\begin{array}{c}0.372 \\
(0.295)\end{array}$ & $\begin{array}{l}-0.139 \\
(0.152)\end{array}$ & $\begin{array}{l}-0.167 \\
(0.224)\end{array}$ & $\begin{array}{c}0.501 \\
(0.442)\end{array}$ \\
\hline $\begin{array}{l}\text { Affiliated in the Last } \\
\text { Year }(\%)\end{array}$ & $\begin{array}{l}2.14 \% \\
\{279\}\end{array}$ & $\begin{array}{c}0.0322 \\
(0.0368)\end{array}$ & $\begin{array}{c}-0.000114 \\
(0.0220)\end{array}$ & $\begin{array}{r}0.0549 * * \\
(0.0268)\end{array}$ & $\begin{array}{l}0.0998^{*} \\
(0.0550)\end{array}$ \\
\hline Population (log) & $\begin{array}{l}3.08 \% \\
\{412\}\end{array}$ & $\begin{array}{l}-0.153 \\
(0.215)\end{array}$ & $\begin{array}{r}-0.0890 \\
(0.120)\end{array}$ & $\begin{array}{r}-0.0477 \\
(0.171)\end{array}$ & $\begin{array}{l}-0.458 \\
(0.439)\end{array}$ \\
\hline $\begin{array}{l}\text { Per Capita Monthly } \\
\text { Income }\end{array}$ & $\begin{array}{c}9.31 \% \\
\{1,134\}\end{array}$ & $\begin{array}{c}-16.33^{* *} \\
(8.283)\end{array}$ & $\begin{array}{l}-13.97^{*} \\
(7.938)\end{array}$ & $\begin{array}{l}-10.07 \\
(11.61)\end{array}$ & $\begin{array}{l}-36.81 \\
(27.78)\end{array}$ \\
\hline Party State Governor & $\begin{array}{l}2.10 \% \\
\{274\}\end{array}$ & $\begin{array}{l}-0.0355 \\
(0.0606)\end{array}$ & $\begin{array}{c}0.0275 \\
(0.0280)\end{array}$ & $\begin{array}{c}0.0429 \\
(0.0404)\end{array}$ & $\begin{array}{l}0.0358 \\
(0.106)\end{array}$ \\
\hline $\begin{array}{l}\text { Literacy among } 15+ \\
\text { y.o. }(\%)\end{array}$ & $\begin{array}{l}5.47 \% \\
\{696\}\end{array}$ & $\begin{array}{l}-0.885 \\
(0.958)\end{array}$ & $\begin{array}{l}-0.997 \\
(0.755)\end{array}$ & $\begin{array}{l}-0.857 \\
(0.992)\end{array}$ & $\begin{array}{c}4.276 \\
(3.123)\end{array}$ \\
\hline Number of Candidates & $\begin{array}{l}3.00 \% \\
\{404\}\end{array}$ & $\begin{array}{c}0.266 \\
(0.227)\end{array}$ & $\begin{array}{l}0.0794 \\
(0.124)\end{array}$ & $\begin{array}{c}0.134 \\
(0.170)\end{array}$ & $\begin{array}{c}0.194 \\
(0.447)\end{array}$ \\
\hline $\begin{array}{l}\text { Log Munic. Area } \\
\left(\mathrm{km}^{2}\right)\end{array}$ & $\begin{array}{l}3.04 \% \\
\{408\}\end{array}$ & $\begin{array}{c}0.134 \\
(0.178)\end{array}$ & $\begin{array}{c}0.152 \\
(0.0999)\end{array}$ & $\begin{array}{c}0.214 \\
(0.138)\end{array}$ & $\begin{array}{l}-0.316 \\
(0.366)\end{array}$ \\
\hline Bandwidth & & IKBW & $10 \%$ & $5 \%$ & $1 \%$ \\
\hline Observations & & - & 1,200 & 634 & 140 \\
\hline
\end{tabular}

See notes to Table 2.B5. 
Table 2.B8: Incumbency Effects on Voter Affiliation - Validity Checks, by Literacy Rate - PMDB (1/2)

$\begin{array}{lllll}\text { IKBW } & & & & \\ \text { obs }\} & (1) & (2) & (3) & (4)\end{array}$

Tests of Quasi-Random Assignment (Effects on Pre-Determined Covariates)

Panel A: Municipalities with Below-Median Literacy

\begin{tabular}{|c|c|c|c|c|c|}
\hline Party Affiliates (\%) & $\begin{array}{l}3.75 \% \\
\{714\}\end{array}$ & $\begin{array}{c}0.319 \\
(0.338)\end{array}$ & $\begin{array}{c}0.256 \\
(0.214)\end{array}$ & $\begin{array}{c}0.259 \\
(0.285)\end{array}$ & $\begin{array}{c}0.233 \\
(0.746)\end{array}$ \\
\hline $\begin{array}{l}\text { Affiliated in the Last } \\
\text { Year }(\%)\end{array}$ & $\begin{array}{l}1.49 \% \\
\{287\}\end{array}$ & $\begin{array}{l}-0.0111 \\
(0.0263)\end{array}$ & $\begin{array}{l}0.0317^{*} \\
(0.0192)\end{array}$ & $\begin{array}{c}0.0209 \\
(0.0179)\end{array}$ & $\begin{array}{l}-0.0113 \\
(0.0271)\end{array}$ \\
\hline Population (log) & $\begin{array}{l}2.38 \% \\
\{464\}\end{array}$ & $\begin{array}{r}-0.0667 \\
(0.135)\end{array}$ & $\begin{array}{l}-0.110^{*} \\
(0.0661)\end{array}$ & $\begin{array}{c}-0.121 \\
(0.0915)\end{array}$ & $\begin{array}{c}0.00213 \\
(0.218)\end{array}$ \\
\hline $\begin{array}{l}\text { Per Capita Monthly } \\
\text { Income }\end{array}$ & $\begin{array}{c}7.16 \% \\
\{1,385\}\end{array}$ & $\begin{array}{l}-5.130 \\
(3.286)\end{array}$ & $\begin{array}{l}-3.609 \\
(2.666)\end{array}$ & $\begin{array}{l}-5.527 \\
(4.005)\end{array}$ & $\begin{array}{c}1.589 \\
(7.819)\end{array}$ \\
\hline Party State Governor & $\begin{array}{l}2.22 \% \\
\{422\}\end{array}$ & $\begin{array}{c}0.0342 \\
(0.0692)\end{array}$ & $\begin{array}{c}0.0536 \\
(0.0345)\end{array}$ & $\begin{array}{c}0.0297 \\
(0.0482)\end{array}$ & $\begin{array}{c}0.151 \\
(0.108)\end{array}$ \\
\hline $\begin{array}{l}\text { Literacy among } 15+ \\
\text { y.o. }(\%)\end{array}$ & $\begin{array}{l}4.83 \% \\
\{943\}\end{array}$ & $\begin{array}{c}0.909 \\
(0.972)\end{array}$ & $\begin{array}{c}0.147 \\
(0.656)\end{array}$ & $\begin{array}{c}0.800 \\
(0.960)\end{array}$ & $\begin{array}{c}1.343 \\
(2.390)\end{array}$ \\
\hline Number of Candidates & $\begin{array}{l}2.52 \% \\
\{497\}\end{array}$ & $\begin{array}{r}-0.264^{*} \\
(0.147)\end{array}$ & $\begin{array}{r}-0.187^{* *} \\
(0.0814)\end{array}$ & $\begin{array}{c}-0.248^{* *} \\
(0.109)\end{array}$ & $\begin{array}{l}-0.392^{*} \\
(0.221)\end{array}$ \\
\hline $\begin{array}{l}\text { Log Munic. Area } \\
\left(\mathrm{km}^{2}\right)\end{array}$ & $\begin{array}{l}2.92 \% \\
\{570\}\end{array}$ & $\begin{array}{r}-0.0957 \\
(0.163)\end{array}$ & $\begin{array}{c}0.00670 \\
(0.0840)\end{array}$ & $\begin{array}{l}0.0124 \\
(0.120)\end{array}$ & $\begin{array}{c}0.135 \\
(0.285)\end{array}$ \\
\hline $\begin{array}{l}\text { Bandwidth } \\
\text { Observations }\end{array}$ & & $\underset{-}{\mathrm{IKBW}}$ & $\begin{array}{l}10 \% \\
1,864\end{array}$ & $\begin{array}{l}5 \% \\
976\end{array}$ & $\begin{array}{l}1 \% \\
190\end{array}$ \\
\hline
\end{tabular}

See notes to Table 2.B5. 
Table 2.B9: Incumbency Effects on Voter Affiliation - Validity Checks, by Literacy Rate - PMDB (2/2)

\begin{tabular}{|c|c|c|c|c|c|}
\hline & $\begin{array}{l}\text { IKBW } \\
\{\mathrm{obs}\}\end{array}$ & $(1)$ & $(2)$ & $(3)$ & $(4)$ \\
\hline \multicolumn{6}{|c|}{ Tests of Quasi-Random Assignment (Effects on Pre-Determined Covariates) } \\
\hline \multicolumn{6}{|c|}{ Panel B: Municipalities with Above-Median Literacy } \\
\hline Party Affiliates (\%) & $\begin{array}{l}3.76 \% \\
\{994\}\end{array}$ & $\begin{array}{l}-0.136 \\
(0.386)\end{array}$ & $\begin{array}{l}-0.237 \\
(0.219)\end{array}$ & $\begin{array}{l}-0.231 \\
(0.328)\end{array}$ & $\begin{array}{l}-0.257 \\
(0.766)\end{array}$ \\
\hline $\begin{array}{l}\text { Affiliated in the Last } \\
\text { Year }(\%)\end{array}$ & $\begin{array}{l}1.94 \% \\
\{503\}\end{array}$ & $\begin{array}{l}-0.0155 \\
(0.0382)\end{array}$ & $\begin{array}{c}0.0403^{* *} \\
(0.0183)\end{array}$ & $\begin{array}{l}-0.0115 \\
(0.0271)\end{array}$ & $\begin{array}{c}0.0149 \\
(0.0600)\end{array}$ \\
\hline Population (log) & $\begin{array}{l}2.22 \% \\
\{579\}\end{array}$ & $\begin{array}{l}-0.118 \\
(0.181)\end{array}$ & $\begin{array}{l}-0.0299 \\
(0.0801)\end{array}$ & $\begin{array}{l}0.0375 \\
(0.117)\end{array}$ & $\begin{array}{l}-0.152 \\
(0.281)\end{array}$ \\
\hline $\begin{array}{l}\text { Per Capita Monthly } \\
\text { Income }\end{array}$ & $\begin{array}{c}9.39 \% \\
\{2,333\}\end{array}$ & $\begin{array}{l}-4.384 \\
(5.814)\end{array}$ & $\begin{array}{l}-4.621 \\
(5.755)\end{array}$ & $\begin{array}{l}-14.94^{*} \\
(8.106)\end{array}$ & $\begin{array}{l}-16.42 \\
(17.05)\end{array}$ \\
\hline Party State Governor & $\begin{array}{l}2.12 \% \\
\{552\}\end{array}$ & $\begin{array}{l}-0.166^{* *} \\
(0.0700)\end{array}$ & $\begin{array}{r}-0.0632^{*} \\
(0.0323)\end{array}$ & $\begin{array}{c}-0.0920^{* *} \\
(0.0450)\end{array}$ & $\begin{array}{c}-0.257^{* *} \\
(0.107)\end{array}$ \\
\hline $\begin{array}{l}\text { Literacy among } 15+ \\
\text { y.o. }(\%)\end{array}$ & $\begin{array}{c}4.16 \% \\
\{1,080\}\end{array}$ & $\begin{array}{l}-0.255 \\
(0.445)\end{array}$ & $\begin{array}{l}-0.140 \\
(0.284)\end{array}$ & $\begin{array}{l}-0.228 \\
(0.396)\end{array}$ & $\begin{array}{l}-1.301 \\
(0.956)\end{array}$ \\
\hline Number of Candidates & $\begin{array}{l}2.43 \% \\
\{637\}\end{array}$ & $\begin{array}{l}0.0872 \\
(0.151)\end{array}$ & $\begin{array}{c}0.0822 \\
(0.0734)\end{array}$ & $\begin{array}{l}0.0383 \\
(0.104)\end{array}$ & $\begin{array}{c}-0.0524 \\
(0.271)\end{array}$ \\
\hline $\begin{array}{l}\text { Log Munic. Area } \\
\left(\mathrm{km}^{2}\right)\end{array}$ & $\begin{array}{l}2.30 \% \\
\{598\}\end{array}$ & $\begin{array}{c}-0.0983 \\
(0.162)\end{array}$ & $\begin{array}{c}-0.0862 \\
(0.0710)\end{array}$ & $\begin{array}{c}-0.00835 \\
(0.106)\end{array}$ & $\begin{array}{c}-0.0405 \\
(0.254)\end{array}$ \\
\hline Bandwidth & & IKBW & $10 \%$ & $5 \%$ & $1 \%$ \\
\hline Observations & & - & 2,449 & 1,306 & 262 \\
\hline
\end{tabular}

See notes to Table 2.B5. 
Table 2.B10: Incumbency Effects on Voter Affiliation - Validity Checks, by Literacy Rate - PSDB (1/2)

\begin{tabular}{|c|c|c|c|c|c|}
\hline & $\begin{array}{l}\text { IKBW } \\
\{\mathrm{obs}\}\end{array}$ & $(1)$ & $(2)$ & $(3)$ & $(4)$ \\
\hline \multirow{2}{*}{\multicolumn{6}{|c|}{$\begin{array}{l}\text { Tests of Quasi-Random Assignment (Effects on Pre-De } \\
\text { Panel A: Municipalities with Below-Median Literacy }\end{array}$}} \\
\hline & & & & & \\
\hline Party Affiliates (\%) & $\begin{array}{l}3.25 \% \\
\{476\}\end{array}$ & $\begin{array}{l}-0.254 \\
(0.221)\end{array}$ & $\begin{array}{l}0.0310 \\
(0.120)\end{array}$ & $\begin{array}{l}-0.178 \\
(0.176)\end{array}$ & $\begin{array}{l}-0.317 \\
(0.394)\end{array}$ \\
\hline $\begin{array}{l}\text { Affiliated in the Last } \\
\text { Year }(\%)\end{array}$ & $\begin{array}{l}1.76 \% \\
\{257\}\end{array}$ & $\begin{array}{r}-0.00578 \\
(0.0156)\end{array}$ & $\begin{array}{l}0.0174^{*} \\
(0.0102)\end{array}$ & $\begin{array}{l}0.00620 \\
(0.0106)\end{array}$ & $\begin{array}{c}0.0151 \\
(0.0141)\end{array}$ \\
\hline Population (log) & $\begin{array}{l}2.70 \% \\
\{400\}\end{array}$ & $\begin{array}{c}0.132 \\
(0.142)\end{array}$ & $\begin{array}{c}0.111 \\
(0.0778)\end{array}$ & $\begin{array}{l}0.191^{*} \\
(0.105)\end{array}$ & $\begin{array}{r}-0.0930 \\
(0.267)\end{array}$ \\
\hline $\begin{array}{l}\text { Per Capita Monthly } \\
\text { Income }\end{array}$ & $\begin{array}{c}8.28 \% \\
\{1,213\}\end{array}$ & $\begin{array}{l}1.889 \\
(3.182)\end{array}$ & $\begin{array}{l}-0.864 \\
(2.928)\end{array}$ & $\begin{array}{c}3.024 \\
(3.880)\end{array}$ & $\begin{array}{c}6.447 \\
(9.293)\end{array}$ \\
\hline Party State Governor & $\begin{array}{l}2.41 \% \\
\{347\}\end{array}$ & $\begin{array}{l}0.00619 \\
(0.0558)\end{array}$ & $\begin{array}{l}-0.0250 \\
(0.0322)\end{array}$ & $\begin{array}{l}-0.0150 \\
(0.0431)\end{array}$ & $\begin{array}{l}0.0591 \\
(0.102)\end{array}$ \\
\hline $\begin{array}{l}\text { Literacy among } 15+ \\
\text { y.o. }(\%)\end{array}$ & $\begin{array}{l}4.41 \% \\
\{663\}\end{array}$ & $\begin{array}{c}1.274 \\
(1.017)\end{array}$ & $\begin{array}{c}0.658 \\
(0.708)\end{array}$ & $\begin{array}{l}1.707^{*} \\
(0.948)\end{array}$ & $\begin{array}{l}-2.784 \\
(2.256)\end{array}$ \\
\hline Number of Candidates & $\begin{array}{l}2.51 \% \\
\{367\}\end{array}$ & $\begin{array}{c}0.163 \\
(0.209)\end{array}$ & $\begin{array}{c}0.242^{* *} \\
(0.101)\end{array}$ & $\begin{array}{l}0.272^{*} \\
(0.143)\end{array}$ & $\begin{array}{c}0.345 \\
(0.419)\end{array}$ \\
\hline $\begin{array}{l}\text { Log Munic. Area } \\
\left(\mathrm{km}^{2}\right)\end{array}$ & $\begin{array}{l}3.19 \% \\
\{466\}\end{array}$ & $\begin{array}{l}-0.172 \\
(0.186)\end{array}$ & $\begin{array}{c}0.00610 \\
(0.103)\end{array}$ & $\begin{array}{r}-0.0676 \\
(0.141)\end{array}$ & $\begin{array}{c}0.372 \\
(0.337)\end{array}$ \\
\hline Bandwidth & & IKBW & $10 \%$ & $5 \%$ & $1 \%$ \\
\hline Observations & & - & 1,427 & 763 & 151 \\
\hline
\end{tabular}

See notes to Table 2.B5. 
Table 2.B11: Incumbency Effects on Voter Affiliation - Validity Checks, by Literacy Rate - PSDB (2/2)

\begin{tabular}{|c|c|c|c|c|c|}
\hline & $\begin{array}{l}\text { IKBW } \\
\{\text { obs }\}\end{array}$ & $(1)$ & $(2)$ & $(3)$ & $(4)$ \\
\hline \multirow{2}{*}{\multicolumn{6}{|c|}{$\begin{array}{l}\text { Tests of Quasi-Random Assignment (Effects on Pre-De } \\
\text { Panel B: Municipalities with Above-Median Literacy }\end{array}$}} \\
\hline & & & & & \\
\hline Party Affiliates (\%) & $\begin{array}{l}3.30 \% \\
\{521\}\end{array}$ & $\begin{array}{c}0.284 \\
(0.264)\end{array}$ & $\begin{array}{l}0.288^{*} \\
(0.158)\end{array}$ & $\begin{array}{c}0.337 \\
(0.226)\end{array}$ & $\begin{array}{c}0.322 \\
(0.374)\end{array}$ \\
\hline $\begin{array}{l}\text { Affiliated in the Last } \\
\text { Year }(\%)\end{array}$ & $\begin{array}{l}1.55 \% \\
\{219\}\end{array}$ & $\begin{array}{c}0.0129 \\
(0.0830)\end{array}$ & $\begin{array}{c}0.0207 \\
(0.0262)\end{array}$ & $\begin{array}{l}-0.0105 \\
(0.0444)\end{array}$ & $\begin{array}{l}0.0416 \\
(0.122)\end{array}$ \\
\hline Population (log) & $\begin{array}{l}3.05 \% \\
\{484\}\end{array}$ & $\begin{array}{c}-0.0200 \\
(0.206)\end{array}$ & $\begin{array}{r}-0.0148 \\
(0.121)\end{array}$ & $\begin{array}{r}0.00957 \\
(0.166)\end{array}$ & $\begin{array}{c}0.149 \\
(0.383)\end{array}$ \\
\hline $\begin{array}{l}\text { Per Capita Monthly } \\
\text { Income }\end{array}$ & $\begin{array}{c}8.57 \% \\
\{1,311\}\end{array}$ & $\begin{array}{l}-6.782 \\
(8.112)\end{array}$ & $\begin{array}{l}-6.952 \\
(7.452)\end{array}$ & $\begin{array}{l}-12.33 \\
(10.22)\end{array}$ & $\begin{array}{l}-3.187 \\
(24.13)\end{array}$ \\
\hline Party State Governor & $\begin{array}{l}2.39 \% \\
\{365\}\end{array}$ & $\begin{array}{l}-0.0546 \\
(0.0663)\end{array}$ & $\begin{array}{l}-0.0331 \\
(0.0295)\end{array}$ & $\begin{array}{l}-0.0225 \\
(0.0420)\end{array}$ & $\begin{array}{r}-0.0928 \\
(0.117)\end{array}$ \\
\hline $\begin{array}{l}\text { Literacy among } 15+ \\
\text { y.o. }(\%)\end{array}$ & $\begin{array}{l}4.36 \% \\
\{680\}\end{array}$ & $\begin{array}{l}-1.056^{*} \\
(0.564)\end{array}$ & $\begin{array}{r}-0.634^{*} \\
(0.358)\end{array}$ & $\begin{array}{l}-0.970^{*} \\
(0.522)\end{array}$ & $\begin{array}{c}0.697 \\
(1.323)\end{array}$ \\
\hline Number of Candidates & $\begin{array}{l}2.93 \% \\
\{471\}\end{array}$ & $\begin{array}{l}-0.143 \\
(0.212)\end{array}$ & $\begin{array}{l}-0.124 \\
(0.112)\end{array}$ & $\begin{array}{l}-0.178 \\
(0.157)\end{array}$ & $\begin{array}{r}-0.0934 \\
(0.370)\end{array}$ \\
\hline $\begin{array}{l}\text { Log Munic. Area } \\
\left(\mathrm{km}^{2}\right)\end{array}$ & $\begin{array}{l}2.89 \% \\
\{462\}\end{array}$ & $\begin{array}{c}0.186 \\
(0.177)\end{array}$ & $\begin{array}{l}0.214^{* *} \\
(0.0981)\end{array}$ & $\begin{array}{c}0.244^{*} \\
(0.136)\end{array}$ & $\begin{array}{c}0.229 \\
(0.304)\end{array}$ \\
\hline Bandwidth & & IKBW & $10 \%$ & $5 \%$ & $1 \%$ \\
\hline Observations & & - & 1,510 & 779 & 145 \\
\hline
\end{tabular}

See notes to Table 2.B5. 
Table 2.B12: Incumbency Effects on Voter Affiliation - Validity Checks, by Literacy Rate - PT (1/2)

\begin{tabular}{|c|c|c|c|c|c|}
\hline & $\begin{array}{l}\text { IKBW } \\
\{\text { obs }\}\end{array}$ & $(1)$ & $(2)$ & $(3)$ & $(4)$ \\
\hline \multirow{2}{*}{\multicolumn{6}{|c|}{$\begin{array}{l}\text { Tests of Quasi-Random Assignment (Effects on Pre-Det } \\
\text { Panel A: Municipalities with Below-Median Literacy }\end{array}$}} \\
\hline & & & & & \\
\hline Party Affiliates (\%) & $\begin{array}{l}3.33 \% \\
\{188\}\end{array}$ & $\begin{array}{l}0.0407 \\
(0.293)\end{array}$ & $\begin{array}{l}-0.139 \\
(0.180)\end{array}$ & $\begin{array}{l}-0.150 \\
(0.250)\end{array}$ & $\begin{array}{c}0.460 \\
(0.446)\end{array}$ \\
\hline $\begin{array}{l}\text { Affiliated in the Last } \\
\text { Year }(\%)\end{array}$ & $\begin{array}{l}2.36 \% \\
\{124\}\end{array}$ & $\begin{array}{c}0.0742 \\
(0.0586)\end{array}$ & $\begin{array}{r}-0.00240 \\
(0.0430)\end{array}$ & $\begin{array}{c}0.0295 \\
(0.0555)\end{array}$ & $\begin{array}{c}0.162 \\
(0.135)\end{array}$ \\
\hline Population (log) & $\begin{array}{l}3.39 \% \\
\{191\}\end{array}$ & $\begin{array}{l}-0.148 \\
(0.231)\end{array}$ & $\begin{array}{l}-0.0330 \\
(0.120)\end{array}$ & $\begin{array}{r}-0.0631 \\
(0.182)\end{array}$ & $\begin{array}{l}-0.110 \\
(0.425)\end{array}$ \\
\hline $\begin{array}{l}\text { Per Capita Monthly } \\
\text { Income }\end{array}$ & $\begin{array}{l}8.66 \% \\
\{425\}\end{array}$ & $\begin{array}{l}-7.807 \\
(7.538)\end{array}$ & $\begin{array}{l}-6.510 \\
(6.787)\end{array}$ & $\begin{array}{l}-10.33 \\
(10.23)\end{array}$ & $\begin{array}{c}22.78 \\
(21.89)\end{array}$ \\
\hline Party State Governor & $\begin{array}{l}2.81 \% \\
\{160\}\end{array}$ & $\begin{array}{l}0.0955 \\
(0.118)\end{array}$ & $\begin{array}{l}0.00726 \\
(0.0526)\end{array}$ & $\begin{array}{c}0.106 \\
(0.0810)\end{array}$ & $\begin{array}{c}0.344 \\
(0.330)\end{array}$ \\
\hline $\begin{array}{l}\text { Literacy among } 15+ \\
\text { y.o. }(\%)\end{array}$ & $\begin{array}{l}6.50 \% \\
\{309\}\end{array}$ & $\begin{array}{l}-0.102 \\
(1.632)\end{array}$ & $\begin{array}{c}0.242 \\
(1.340)\end{array}$ & $\begin{array}{c}0.912 \\
(1.850)\end{array}$ & $\begin{array}{l}17.42^{* *} \\
(6.887)\end{array}$ \\
\hline Number of Candidates & $\begin{array}{l}3.10 \% \\
\{171\}\end{array}$ & $\begin{array}{c}0.220 \\
(0.345)\end{array}$ & $\begin{array}{c}0.129 \\
(0.191)\end{array}$ & $\begin{array}{c}0.220 \\
(0.272)\end{array}$ & $\begin{array}{c}0.175 \\
(0.866)\end{array}$ \\
\hline $\begin{array}{l}\text { Log Munic. Area } \\
\left(\mathrm{km}^{2}\right)\end{array}$ & $\begin{array}{l}2.94 \% \\
\{168\}\end{array}$ & $\begin{array}{c}-0.0754 \\
(0.347)\end{array}$ & $\begin{array}{c}0.167 \\
(0.177)\end{array}$ & $\begin{array}{c}0.104 \\
(0.250)\end{array}$ & $\begin{array}{r}-1.148^{*} \\
(0.576)\end{array}$ \\
\hline Bandwidth & & IKBW & $10 \%$ & $5 \%$ & $1 \%$ \\
\hline Observations & & - & 472 & 252 & 60 \\
\hline
\end{tabular}

See notes to Table 2.B5. 
Table 2.B13: Incumbency Effects on Voter Affiliation - Validity Checks, by Literacy Rate - PT (2/2)

\begin{tabular}{|c|c|c|c|c|c|}
\hline & $\begin{array}{c}\text { IKBW } \\
\{\text { obs }\}\end{array}$ & $(1)$ & $(2)$ & $(3)$ & $(4)$ \\
\hline \multirow{2}{*}{\multicolumn{6}{|c|}{$\begin{array}{l}\text { Tests of Quasi-Random Assignment (Effects on Pre-D } \\
\text { Panel B: Municipalities with Above-Median Literacy }\end{array}$}} \\
\hline & & & & & \\
\hline Party Affiliates (\%) & $\begin{array}{l}3.58 \% \\
\{279\}\end{array}$ & $\begin{array}{l}0.0322 \\
(0.338)\end{array}$ & $\begin{array}{l}-0.180 \\
(0.227)\end{array}$ & $\begin{array}{l}-0.210 \\
(0.325)\end{array}$ & $\begin{array}{c}0.617 \\
(0.734)\end{array}$ \\
\hline $\begin{array}{l}\text { Affiliated in the Last } \\
\text { Year }(\%)\end{array}$ & $\begin{array}{l}2.11 \% \\
\{168\}\end{array}$ & $\begin{array}{c}0.0316 \\
(0.0355)\end{array}$ & $\begin{array}{l}0.00282 \\
(0.0243)\end{array}$ & $\begin{array}{c}0.0722 * * * \\
(0.0256)\end{array}$ & $\begin{array}{l}0.110^{* *} \\
(0.0461)\end{array}$ \\
\hline Population (log) & $\begin{array}{l}3.54 \% \\
\{274\}\end{array}$ & $\begin{array}{l}-0.172 \\
(0.300)\end{array}$ & $\begin{array}{c}-0.0416 \\
(0.170)\end{array}$ & $\begin{array}{l}0.0494 \\
(0.248)\end{array}$ & $\begin{array}{l}-0.677 \\
(0.649)\end{array}$ \\
\hline $\begin{array}{l}\text { Per Capita Monthly } \\
\text { Income }\end{array}$ & $\begin{array}{l}8.41 \% \\
\{626\}\end{array}$ & $\begin{array}{l}-17.54 \\
(12.19)\end{array}$ & $\begin{array}{l}-17.10 \\
(11.15)\end{array}$ & $\begin{array}{l}-9.037 \\
(16.54)\end{array}$ & $\begin{array}{l}-73.26^{*} \\
(41.63)\end{array}$ \\
\hline Party State Governor & $\begin{array}{l}2.09 \% \\
\{166\}\end{array}$ & $\begin{array}{l}-0.113^{*} \\
(0.0604)\end{array}$ & $\begin{array}{c}0.0274 \\
(0.0297)\end{array}$ & $\begin{array}{c}-0.00484 \\
(0.0430)\end{array}$ & $\begin{array}{c}-0.104 \\
(0.0954)\end{array}$ \\
\hline $\begin{array}{l}\text { Literacy among } 15+ \\
\text { y.o. }(\%)\end{array}$ & $\begin{array}{l}3.39 \% \\
\{265\}\end{array}$ & $\begin{array}{l}-1.294 \\
(0.811)\end{array}$ & $\begin{array}{l}-0.327 \\
(0.469)\end{array}$ & $\begin{array}{l}-0.821 \\
(0.636)\end{array}$ & $\begin{array}{c}-3.103^{* *} \\
(1.540)\end{array}$ \\
\hline Number of Candidates & $\begin{array}{l}2.80 \% \\
\{215\}\end{array}$ & $\begin{array}{c}0.340 \\
(0.328)\end{array}$ & $\begin{array}{c}0.159 \\
(0.162)\end{array}$ & $\begin{array}{c}0.194 \\
(0.227)\end{array}$ & $\begin{array}{c}0.229 \\
(0.611)\end{array}$ \\
\hline $\begin{array}{l}\text { Log Munic. Area } \\
\left(\mathrm{km}^{2}\right)\end{array}$ & $\begin{array}{l}3.56 \% \\
\{278\}\end{array}$ & $\begin{array}{c}0.295 \\
(0.223)\end{array}$ & $\begin{array}{c}0.147 \\
(0.126)\end{array}$ & $\begin{array}{c}0.273 \\
(0.181)\end{array}$ & $\begin{array}{l}0.0901 \\
(0.462)\end{array}$ \\
\hline Bandwidth & & IKBW & $10 \%$ & $5 \%$ & $1 \%$ \\
\hline Observations & & - & 728 & 382 & 80 \\
\hline
\end{tabular}

See notes to Table 2.B5. 
Table 2.B14: Summary Statistics for All Municipalities, 2004-2012

\begin{tabular}{lrcc}
\hline Variable & & $\begin{array}{r}\text { Standard } \\
\text { Deviation }\end{array}$ \\
\hline Affiliated Voters (\%) & 49,322 & 12.01 & 6.485 \\
Beneficiaries in December (\%) & 49,322 & 8.733 & 4.896 \\
Population (log) & 49,322 & 9.366 & 1.093 \\
Log Munic. Area $\left(k m^{2}\right)$ & 49,322 & 6.205 & 1.280 \\
Urban Population (\%) & 49,322 & 61.39 & 22.58 \\
Literacy among 15+ Year-olds (\%), State Level & 49,322 & 86.21 & 7.680 \\
Individuals w/ College Degree (\%), State Level & 49,322 & 7.044 & 3.215 \\
Per Capita Monthly Income, State Level & 49,322 & 300.2 & 117.5 \\
\hline
\end{tabular}

The unit of observation is a year-municipality, pooling years from 2004 to 2012 . 


\section{Political Preaching in the Classroom: Evidence from Party Affiliation of Teachers in Brazilian Public Schools*}

\subsection{Introduction}

Frequently regarded as one of the crucial inputs in the educational process (Rockoff (2004)), teachers commonly stand among the politically engaged groups with the most influence on shaping essential public policies and on promoting economic and social development. ${ }^{1}$ However, a seemingly underappreciated topic by both the economics and political science literatures has been the role that politically active teachers might perform in political environments and especially the influence they may exert on the electoral process. Despite the suggestion by contemporary observers that faculty would be indoctrinating students with certain politically bent education (Horowitz (2006)), the literature on political behavior has focused on exploring the effect on students' political attitudes stemming from education acquisition as a whole (Persson (2014); Kam and Palmer (2008)), with no special regard for the particular influence of partisan political preaching by teachers with strong political views. It seems natural to think, though, that while facing great audiences of recently registered voters and individuals who just got into political questioning, teachers may play a unique and important part not only in their students' political (and partisan) stances, but also in the configuration of electoral outcomes. At the very least, they hold a prime position to discuss political matters with their students; however, they could also present themselves as self-appointed party delegates trying to deliver their students' votes, or even as political power brokers involved in clientelistic relationships ${ }^{2}$ - especially in the developing world, where these practices tend to be widespread. ${ }^{3}$ Notwithstanding, we have no knowledge of studies addressing the extent to which teachers are able to influence voting behavior.

\footnotetext{
*With Luís Eduardo N. Meloni.

${ }^{1}$ In the context of teachers' unionisation, for instance, it has been argued that the acquisition of bargaining power by such agents may have important consequences on resource allocation in public schools (Hoxby (1996); Moe (2011)).

${ }^{2}$ The case for contexts of education provision as particularly prone for the flourishing of patronage is made by Corrales (2006), for instance.

${ }^{3}$ See, for instance, Kitschelt and Wilkinson (2007) and Schaffer (2007).
} 
In this chapter we investigate this issue by looking at the effects of the presence of partyaffiliated teachers on certain regions' electoral outcomes. Merging a unique individual level database of public high school teachers in São Paulo, Brazil, with an individual level database of party-affiliated voters, we are able to identify high school teachers' political affiliations. Furthermore, we exploit a very rich database of electoral outcomes and electorate characteristics to investigate the relationship between the density of affiliated teachers and the electoral outcomes at a highly disaggregated geographic level, which allows us to get high precision estimates and avoid certain endogeneity issues.

The matter of such an influence by teachers poses as a very relevant question for two main reasons. First, while it may be hard to believe that teachers alone are able to change the outcome of a plurality election by influencing their students' voting behavior, the same is not true for proportional elections, in which the number of votes necessary for being elected might be much smaller, especially in small municipalities. The second reason relies on the fact that evidence on such influence would be a sign that teachers are diverging from the curriculum content standards, which may not only affect electoral outcomes, but also have deleterious effects on education outcomes. ${ }^{4}$

Our research is presented with important empirical challenges, especially concerning the matter of selection in the assignment of teachers to schools. To overcome this issue, we exploit the varying intensity of the hypothesized effect according to electorate characteristics at the polling station level, the specific place in the polling district where each voter is designed to cast his or her vote. We argue that teachers - or voters in general - are not able to select themselves at that level in any manner, and thus controlling for specific characteristics of regions where selection may yet occur should render estimates free of that kind of selection bias. We find evidence of a positive and significant effect of the presence of affiliated teachers on the electoral performance of the corresponding party through influencing their voting-aged students. Moreover, our results show that this effect is more pronounced in plurality elections and appear to be restricted to teachers affiliated to the Workers' Party. For that party, we also find that affiliated teachers do not have an impact on electoral turnout by students; rather, these teachers are suggested to alter the political preferences of students who would vote for another party.

This chapter communicates with at least two different strands of the political economy and political science literatures, as well as to the education literature. First, it is closely related to studies focused on exploring the relationship between education and political participation. Extensive research on this topic has traditionally documented a strong and positive relationship between schooling and political participation: Hillygus (2005), Nie

\footnotetext{
${ }^{4}$ In the context of unionisation, deleterious effects on student performance have been documented by Hoxby (1996) and Eberts and Stone (1987).
} 
et al. (1996) and Wolfinger and Rosenstone (1980), for instance, suggest the connection of higher education to an enhanced voter turnout, political knowledge and civic engagement. ${ }^{5}$ On the other hand, a more rigid exploration of the corresponding causal link has only been developed by more recent work, with mixed findings. While Dee $(2004)$ and Milligan et al. (2004) find a positive effect using U.S. and U.K. data, Persson (2014) and Kam and Palmer (2008) using data from the same countries, and Solis (2014) using data from Chile suggest that the relationship between education and political participation is a spurious correlation.

Differently from that literature, however, this chapter aims to study the influence of specific behavior by a particular group of teachers, namely the political indoctrination of students by their party-affiliated teachers. In this sense, our work is also related to the literature on education as fundamentally a political process and on teachers' behavior in classroom situations. ${ }^{6}$ Under a comparative education approach, Hahn (1998) and Westheimer and Kahne (2004) argue that diversified practices of citizenship education (arguably the subject area most favorable to engagement with political issues) are highly influenced by national political scenarios and driven by different beliefs about democracy, while Schugurensky and Myers (2003) stress teachers' political participation as an important consideration for understanding such practices. In a case study of Brazilian and Canadian secondary teachers, Myers (2007) illustrates the influence of political participation-measured according to involvement in teachers' unions, political parties and social movements - on both pedagogical and curricular approaches.

Lastly, the present work is also related to the political clientelism literature, which explores how and under what conditions certain agents - voters or political power brokerstrade their political support during elections, as well as the inefficiencies stemming from their corresponding rewards. In the context of developing countries, for instance, Finan (2005) presents an example of that practice by arguing that federal deputies in Brazil reward municipalities based on their political support. Regarding the Brazilian educational context, Mainwaring (1999) reports that, as a result of clientelism, in the state of Bahia about 37,000 teachers who were on the public payroll in 1987 had never taught a single class. On the other hand, the more specific analysis of the situations in which political brokers may arise - and what kind of individuals are more likely to play that role - and act to influence electoral outcomes as middlemen between political parties and large groups of voters seems not yet thoroughly developed nor fully understood. One exception is provided by Larreguy (2013), where the establishment of clientelistic networks by communal land leaders in Mexico serves as the basis for an investigation of the

\footnotetext{
${ }^{5}$ This hypothesized effect of educational attainment has sometimes been used to advocate government intervention in the education market (Hanushek (2002)).

${ }^{6}$ See also Ginsburg et al. (1992).
} 
monitoring capabilities presented by political parties in securing their votes.

The remainder of this chapter is organized as follows. Section 2 describes voting procedures in Brazilian elections and the assignment of teachers and students to public schools in São Paulo. Section 3 describes the data and the empirical strategy. Sections 4 and 5 discuss our main results, and Section 6 concludes.

\subsection{Institutional Background}

In this section, we highlight the main features of the Brazilian electoral system and characterize the public education system in the state of São Paulo - for which data on teachers are available - placing particular emphasis on the rules governing student and teacher placement in public schools. ${ }^{7}$

\subsubsection{Voting in Brazil}

Brazilian states and municipalities have autonomous administrations, and both executive leaders and local legislatures are elected by direct elections. Voting is mandatory for literate citizens aged 18-70 and facultative for citizens between 16 and 17 or over 70 , and for illiterate people. Elections in Brazil are held every four years. Elections for president, senators, deputies and governors are held jointly while elections for mayors and city councilors are staggered by two years relative to general elections.

In order to better organize election procedures, each state is divided into polling districts (Zona Eleitoral) which are, in their turn, composed of several polling stations (Seção Eleitoral). Polling districts have their limits defined according to geographical and demographic characteristics and are managed by electoral offices charged with taking care of electoral registers; Figures 3.B1 and 3.B2 in the appendices illustrate the distribution of municipalities within the state of São Paulo and the distribution of polling districts within the city of São Paulo. A polling station, on the other hand, consists of a very specific place in the polling district where each voter is designated to cast his or her vote, usually a specific room in a school or public service center. Buildings (polling places) with one of such polling stations tend, of course, to contain several ones. As such, polling stations represent a highly disaggregated level of observation. Figures 3.B3 and 3.B4 in

\footnotetext{
${ }^{7}$ São Paulo is the wealthiest and most developed state in Brazil, with a population of over 44 million people and a territorial area close to $250,000 \mathrm{~km}^{2}$, equivalent to the area of the state of Michigan or to the United Kingdom.
} 
the appendices provide an illustration of a polling place and a polling station, respectively, and Figure 3.1 below sums up the administrative hierarchy of electoral procedures in Brazil.

Figure 3.1: Administrative Hierarchy of Electoral Procedures in Brazil State Polling district Polling place Polling station
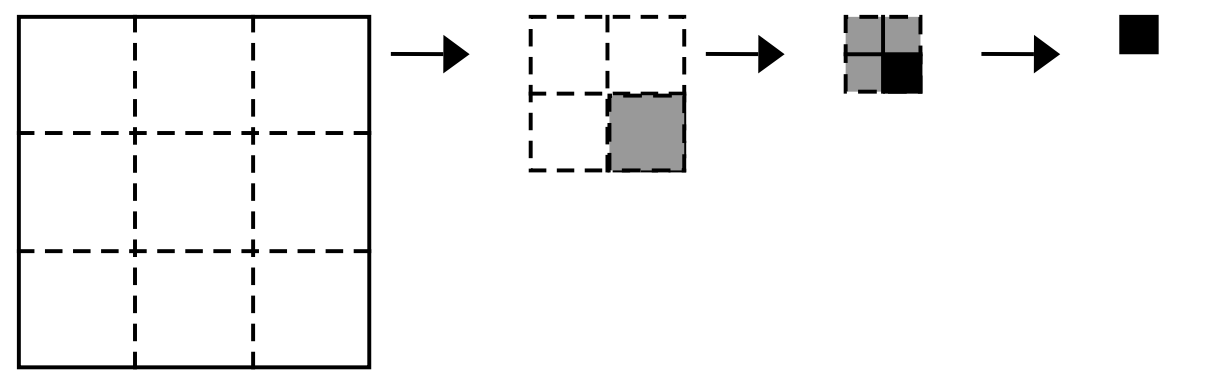

In addition, Brazilian legislation (Código Eleitoral, art. 117) dictates that polling stations have at most 400 voters in the states' capital cities or 300 voters in other cities, and at least 50 voters. $^{8}$ Electoral laws also depict an effort of minimizing the distance between voters' places of residence and the polling stations to which they are assigned: at the time of electoral registration, voters are able to express their preferences over polling places (but not over specific polling stations) in the polling district of their residence, and they are also prohibited from choosing a polling place from a different polling district (Resolução TSE 21.538/2003, art. 9). ${ }^{9}$

\subsubsection{The Brazilian Public Educational System}

Public education in Brazil is free of charge to all Brazilian citizens and can be provided by municipalities, states or the federal government, depending on the level of education. The pre-college educational system is arranged into four levels: preschool (attended by 6 year-olds), primary school (attended by 7 to 10 year-olds), secondary school (attended by 11 to 14 year-olds) and high school (attended by 15 to 17 year-olds). Since our main goal is to investigate the influence teachers may present on students' voting patterns, we focus our analysis on the high school level, which comprises students qualified for voting. ${ }^{10}$

Even though São Paulo's public education system is one of the best in Brazil, it is far

\footnotetext{
${ }^{8}$ However, the same legislation also authorizes the regional electoral courts to surpass these limits in exceptional circumstances.

${ }^{9}$ In private communications, a former employee of a regional electoral authority has stated that each voter is automatically allocated to the polling station with the lower number of voters among those stations in the polling place chosen by the voter.

${ }^{10}$ High school education is usually provided by the state government, as directed by the Brazilian Constitution.
} 
from the quality level presented in developed countries, which induces wealthier families to obtain education services from private schools. Nonetheless, the cost of education in private schools is extremely prohibitive for Brazilian standards; thus, around $85 \%$ of the students who achieve high school completion in Brazil do so in public schools. ${ }^{11}$

\subsubsection{Student and Teacher Placement in São Paulo's Public Schools}

The assignment of students to state high schools is regulated by state laws which fundamentally determine that students residing in a given school's area of influence ${ }^{12}$ receive priority in filling that school's class vacancies. The minimum distance criterion is naturally also the first to be considered in the placement of students who do not get to be enrolled in the school that is closest to their homes.

Teacher assignment to these schools, in its turn, occurs on the basis of tests conducted at the state level and specific to the school subject the applicant desires to teach. Applicants must achieve a pre-established minimum score in order to be considered apt for teaching, and those who do so are ranked according to their final score. ${ }^{13}$ A first group of top ranked candidates are then summoned for a session where they select their most preferred school among those with positions still available. School choice is made by one candidate at a time, and priority in that procedure follows the candidates' ranking (better ranked candidates get to pick their schools first). In the event that not all teacher positions are filled, new groups of (lower) ranked candidates are summoned for new school choice sessions until all positions have been filled or all ranked candidates have been summoned. From 2004 to 2008, more than 26,000 positions were opened for basic education (i.e. secondary and high school level) teachers in public schools managed by the state.

\subsection{Data and Estimation Framework}

The present analysis relies on several sources of data. In order to obtain information on teachers' political affiliation, we combine individual level data - from the São Paulo State Department of Education - on public high school teachers in São Paulo's state-managed

\footnotetext{
${ }^{11}$ Source: INEP. Available at http://portal.inep.gov.br/rss_censo-escolar/-/asset_publisher/oV0H/content/id/19910.

${ }^{12}$ The area of influence of a given public (high) school is defined to be (roughly) the region to which the school consists of the closest public (high) school.

${ }^{13}$ Applicants must hold an academic degree called a license, obtained through the completion of specific college courses with a stronger emphasis on teaching methods and pedagogy than those leading to a bachelor's degree. Additional academic degrees like master's or doctorate degrees also contribute to the candidate's final score.
} 
schools from 2008 to 2010 with individual level information on politically affiliated voters for the same years, provided by the federal electoral authority (TSE). We are thus capable of identifying, for each of those years, which of those teachers are affiliated, as well as the political party to which they are affiliated. In particular, we define a teacher to be affiliated if we are able to match his or her name to that of an affiliated voter who appears in the affiliated voter list for the corresponding year. Moreover, we make use of dataalso provided by the TSE - on parties' electoral outcomes at the polling station level and on characteristics of voters allocated to each polling station.

Our study of the relationship between the density of teachers affiliated to a given party and electoral outcomes for that party is made through the construction of measures of political affiliation at the level of regions consisting of intersections between polling districts and municipalities. ${ }^{14}$ This is done in order to gain more variation in our main independent variable, since there are 423 polling districts in the State of São Paulo as defined by the electoral authorities, whereas considering the intersection between polling districts and municipalities leaves us with 790 units of observation. For brevity, we will henceforth refer to such intersections as polling districts, and originally-defined districts will be referred to as "TSE districts" should that need arise. We also believe that this strategy allows us to have a more reasonable measure of the density of party-affiliated teachers as it imposes the restriction that students voting in a given municipality are most likely influenced by teachers in that municipality (but not by teachers in the same TSE district and in other municipalities). A deeper description of the relationship between the distributions of TSE districts and municipalities in the state of São Paulo is given in Tables 3.A1 and 3.A2 in the appendices.

The construction of our measures of density of politically affiliated teachers would be a simple task if information on geographic limits of each of the TSE polling districts were available. Unfortunately, this is not the case. To circumvent this problem we used georeferencing algorithms to match each state school to its closest polling place in the same municipality. Then, we associated each school to the polling district corresponding to the matched polling place. Finally, for each district we were able to compute the proportion of teachers affiliated to each political party.

Although the polling district is not the most disaggregated level at which we may explore regional variation in the density of affiliated teachers, it is the most disaggregated level at which we can credibly match that variation to the variation in electoral outcomes. For instance, an alternative approach would be to consider only those (state-managed) schools that are used as polling places during elections and associate party-affiliated

\footnotetext{
${ }^{14}$ Each originally-defined district may either cover more than one municipality, have its area coincide with one, or be a smaller part of a municipality. Source: http://www.tse.jus.br/eleitor/zonas-eleitorais.
} 
teachers with electoral outcomes at the school level. This approach, however, imposes the strong restriction that students vote at the school whereat they study. As not all polling places are state-managed high schools, restricting our analysis to such schools would impose us a selection problem that could compromise the interpretation of the estimated coefficients.

Before describing our empirical strategy, it is convenient to present some statistics related to our main independent variables, namely the share of high school teachers who are affiliated to each political party. The corresponding figures are displayed in Table 3.1 .

Table 3.1: Share of Teachers Affiliated to Each Party

\begin{tabular}{lcc}
\hline Political Party & 2008 & 2010 \\
\hline PT & $1.98 \%$ & $2.03 \%$ \\
PSDB & $0.99 \%$ & $0.93 \%$ \\
PTB & $0.67 \%$ & $0.65 \%$ \\
PMDB & $0.62 \%$ & $0.62 \%$ \\
PV & $0.43 \%$ & $0.45 \%$ \\
PSB & $0.37 \%$ & $0.35 \%$ \\
PPS & $0.37 \%$ & $0.32 \%$ \\
PP & $0.35 \%$ & $0.32 \%$ \\
DEM & $0.35 \%$ & $0.31 \%$ \\
PDT & $0.33 \%$ & $0.32 \%$ \\
PR & $0.32 \%$ & $0.31 \%$ \\
Others & $1.39 \%$ & $1.50 \%$ \\
\hline Number of High School Teachers & 94,277 & 98,594 \\
\hline
\end{tabular}

Note: the shares of affiliated teachers are relative to the total of high school teachers in São Paulo's public schools.

We focus our analysis on the four parties with the highest numbers of affiliated teachers at the state level: the Workers Party (PT), the Brazilian Social Democratic Party (PSDB), the Brazilian Labour Party (PTB) and the Brazilian Democratic Movement Party (PMDB). The PT is currently one of the most important parties in the Brazilian political scenario, governing at the federal level since 2003. The PSDB has been the PT's main opposition in the federal government and has been ruling the state of São Paulo since 1995, having PT as one of its main rivals at that state. The PTB has not shown great representation in the chamber of deputies and neither has it elected any governor in the last general election, but its relatively high number of affiliated teachers might be explained by its association with unions and labor organizations. In its turn, the PMDB is currently one of the biggest political parties in Brazil, being the second with more elected members in the chamber of deputies. 
Our identification strategy resembles the approaches taken by Duflo (2001) and Card (1992) as we exploit, in a difference-in-differences (DD) setup, variation in two dimensions that jointly determine the exposure of voters to affiliated teachers. As mentioned above, the first dimension, regarding "treatment intensity", consists of the share of teachers affiliated to a given party in each polling district. In turn, the second dimension we explore is related to voter demographic characteristics and amounts to the share of voters registered in each polling station who are likely - or intended - to be treated (i.e. to be high school students under the influence of affiliated teachers). If it is true that the presence of affiliated teachers has a significant effect on electoral outcomes (as a result of indoctrination in the classroom), this effect should be stronger in polling stations with higher shares of students. In order to identify those voters who are high school students, we rely on information on age and educational attainment reported by voters at the moment of electoral registration (information on whether voters are indeed enrolled at each electoral year is not available). We note, however, that information on voter education is measured with some imprecision, since it is very unlikely to be updated after voter registration. ${ }^{15}$ For this reason, using solely the data on educational attainment to infer whether voters are enrolled in high school would possibly lead us to a very imprecise measure of the actual proportion of enrolled voters, as middle-aged voters (for instance) could possibly still be suggested as currently enrolled in high school according to that information. On the other hand, unlike the data on education, information on voters' ages is based on voters' dates of birth and are constantly (automatically) updated by electoral authorities. We then define the group of voters to be most likely affected by high school teachers to be that of voters aged between 16 and 17 and who are listed as having completed secondary education but not high school (this subset of voters will also be referred to as the "target group"). ${ }^{16}$ In particular, since voters aged 16-17 have necessarily just registered, it is far less likely that the information on education listed in their registry is imprecise.

In essence, our approach differs from the archetypical DD example in applied econometrics only in the sense that the variables representing treatment intensity and treatment status are both continuous rather than dummy variables. For each given political party, we consider the model

$$
\begin{aligned}
\text { vote_share }_{s, d}=\beta_{0} & +\beta_{1} \text { teachers_party } \\
& * \text { target_group }_{s, d}+\beta_{2} \text { target_group }_{s, d}+ \\
& +\beta_{3} \text { teachers_party } y_{d}+\varepsilon_{s, d}
\end{aligned}
$$

\footnotetext{
${ }^{15}$ Voters are not required to keep this information updated with the electoral authorities. Rather, this information is usually updated only when the voter moves to a different city or a different district and decides to change his/her polling place.

${ }^{16}$ Since not all voters in the target group are exposed to affiliated teachers in the corresponding polling district, the effect we estimate is analogous to an intent-to-treat (ITT) effect.
} 
where vote_share $e_{s, d}$ is the party's vote share at polling station $s$ in polling district $d$ concerning a given elective position, teachers_party ${ }_{d}$ is the percentage of high school teachers in public schools located in district $d$ who are affiliated to the given party, and target_group $p_{s, d}$ is the share of voters registered in station $s$ (in polling district $d$ ) belonging to the target group. Summary statistics for these variables (as well as for other main variables presented throughout the chapter) are displayed in Tables 3.A3 3.A5 in the appendices.

Naturally, a major concern in interpreting our estimates concerns the assignment of teachers and (student) voters to schools and polling stations. For instance, if teachers' decision processes regarding where to teach contemplated characteristics of the schools' neighborhoods that were correlated with electoral outcomes, our estimated coefficients would likely not be limited to capturing the hypothesized effects, but would rather be plagued by endogeneity issues. Thus, we introduce polling place fixed effects in the above model to particularly avoid such kinds of selection problems. In other words, we assume that once we control for polling place fixed effects, teacher and voter assignment becomes (partially) uncorrelated to political characteristics of polling station cohorts, and that $\beta_{1}$ indeed captures the effect of the interaction between party-affiliated teachers and the segment of the electorate who is more likely to be politically influenced by them. We note that introducing polling place fixed effects should not pose issues to our estimates as the average number of stations within a polling place in our sample is fairly high. ${ }^{17}$

Ultimately, then, we estimate the model

$$
\begin{aligned}
\text { vote_share }_{s, d}=\beta_{0} & +\beta_{1} \text { teachers_party }{ }_{d} * \text { target_group }_{s, d}+\beta_{2} \text { target_group }_{s, d}+ \\
& +\gamma_{b}+\varepsilon_{s, d}
\end{aligned}
$$

where $\gamma_{b}$ denotes a polling place fixed effect, which in particular absorbs all kinds of variation at the polling district level, such as that from teachers_partyd. Aside from separately estimating model $(3.2)$ for each of the four parties listed above, we also consider estimating the effect of interest by pooling the observations for these parties. In that case, our model may be rewritten as

$$
\begin{aligned}
\text { vote_share }_{p, s, d}=\beta_{0} & +\beta_{1} \text { teachers_party } \\
& +\beta_{2, d} \text { target_group } \text { target_group }_{s, d}+\gamma_{b, p}+\varepsilon_{s, d, p}
\end{aligned}
$$

\footnotetext{
${ }^{17}$ Polling places had an average of 7.93 stations in 2008 and 8.27 stations in 2010 .
} 
where vote_share $e_{s, d, p}$ is the vote share obtained by party $p$ at polling station $s$ in polling district $d$, teachers_party $y_{, p}$ is the percentage of high school teachers in public schools located in district $d$ who are affiliated to party $p$, and $\gamma_{b, p}$ denotes a party-polling place fixed effect.

\subsection{Main Results}

To illustrate the specifications considered above, we begin the presentation of our main results by focusing on discussing the estimates obtained for the effect of teachers affiliated to the PT on that party's vote share at the 2010 presidential election. The corresponding results are presented in Table 3.2. Column (1) of that table presents the baseline specification of equation (3.1), while column (3) introduces polling place fixed effects, as described by model (3.2). Also, column (2) considers a slight modification of model (3.2) wherein we replace polling place fixed effects with district fixed effects.

Table 3.2: Effect of Teachers Affiliated to the PT on the Vote Share at the 2010 Presidential Election

\begin{tabular}{cccc}
\hline Dep. Variable: vote_share s $_{s, d}$ & $(1)$ & $(2)$ & $(3)$ \\
\hline$\beta_{1}$ & -0.0058 & $0.0173^{* * *}$ & $0.0061^{*}$ \\
& $(0.0112)$ & $(0.0054)$ & $(0.0033)$ \\
$\beta_{2}$ & $0.2610^{* * *}$ & $0.0350^{* *}$ & $-0.0254^{* *}$ \\
& $(0.0348)$ & $(0.0141)$ & $(0.0108)$ \\
$\beta_{3}$ & $1.5683^{* * *}$ & & \\
& $(0.3719)$ & & \\
Observations & 75,591 & 75,591 & 75,591 \\
R-squared & 0.0480 & 0.6849 & 0.9263 \\
District FE & No & Yes & No \\
Polling Place FE & No & No & Yes
\end{tabular}

Standard errors (in parenthesis) are robust to clustering at the polling district level. $*, * *$, and ${ }^{* * *}$ indicate significance at the $10 \%, 5 \%$ and $1 \%$ levels, respectively.

In particular, coefficient $\beta_{3}$ in column (1) shows, as possibly expected, that the assignment of affiliated teachers across districts is highly (and positively) correlated with the electoral performance of the corresponding party. We are primarily interested, however, in the signal and magnitude of $\beta_{1}$, the coefficient associated with the interaction between the share of affiliated high school teachers and the share of voters in the target group. We first note that the omission of important variables would seriously compromise inferences 
based on our baseline specification (model (3.1)): while $\beta_{1}$ is estimated to be negative (but statistically insignificant) in column (1), the introduction of district and polling place fixed effects in columns (2) and (3), respectively, leads to positive (and significant) estimates of that coefficient. The corresponding estimate in column (3), for instance, indicates that once polling place specific characteristics are accounted for, the correlation between the density of teachers affiliated to the PT and that party's vote share in the 2010 presidential election is stronger in polling stations with higher shares of high school students aged between 16 and 17 .

To better understand the magnitude of the estimate of $\beta_{1}$ presented in column (3), consider a polling station wherein $20 \%$ of the voters belong to the target group. Then, the corresponding estimate indicates that an increase by one percentage point (p.p.) in the share of high school teachers affiliated to the PT (in the related polling district) is associated with an increase by 0.12 p.p. in the PT's vote share at that polling station in the 2010 presidential election as a result of their influence over voting-aged students. Were that polling station to contain 400 voters, for instance, such an effect would correspond to an average increase by approximately 0.5 in the number of votes received by the PT at that station. Such a magnitude may become even more relevant upon the observation that our estimates may be understood as an intent-to-treat effect, since not all voters in the target group are guaranteed to be exposed to affiliated teachers. In that sense, that effect would be more important the smaller the share of voters actually exposed to affiliated teachers.

Next, we proceed to presenting the corresponding results for the four considered political parties, and for each elective position disputed in 2008 and 2010. We do, however, restrict such presentation to the estimates obtained upon the estimation of models $(3.2)$ and (3.3), wherein polling place fixed effects are included. Panels A through D of Table 3.3 present the results for the PT, the PSDB, the PTB, and the PMDB, whereas Panel E of that table shows the estimates obtained upon pooling the observations of these parties. We observe from the latter panel that, aside from the positions of city councilor and federal deputy (which are associated with negative and insignificant coefficients very close to zero), the presence of teachers affiliated to a "generic" party is associated with a positive effect on the vote share exhibited by such a party in all other elections. Moreover, this seems particularly true for elective positions filled under plurality rules - i.e. mayor, governor, president, and senator - for which the magnitude of the coefficients is higher (although the estimate corresponding to the position of mayor is statistically insignificant). The larger effect in Panel $\mathrm{E}$ is found for the position of governor, and indicates that in a polling station wherein $20 \%$ of the voters belong to the target group, a share of $1 \%$ of teachers affiliated to a party is responsible for 0.2 p.p. of the corresponding vote share as 


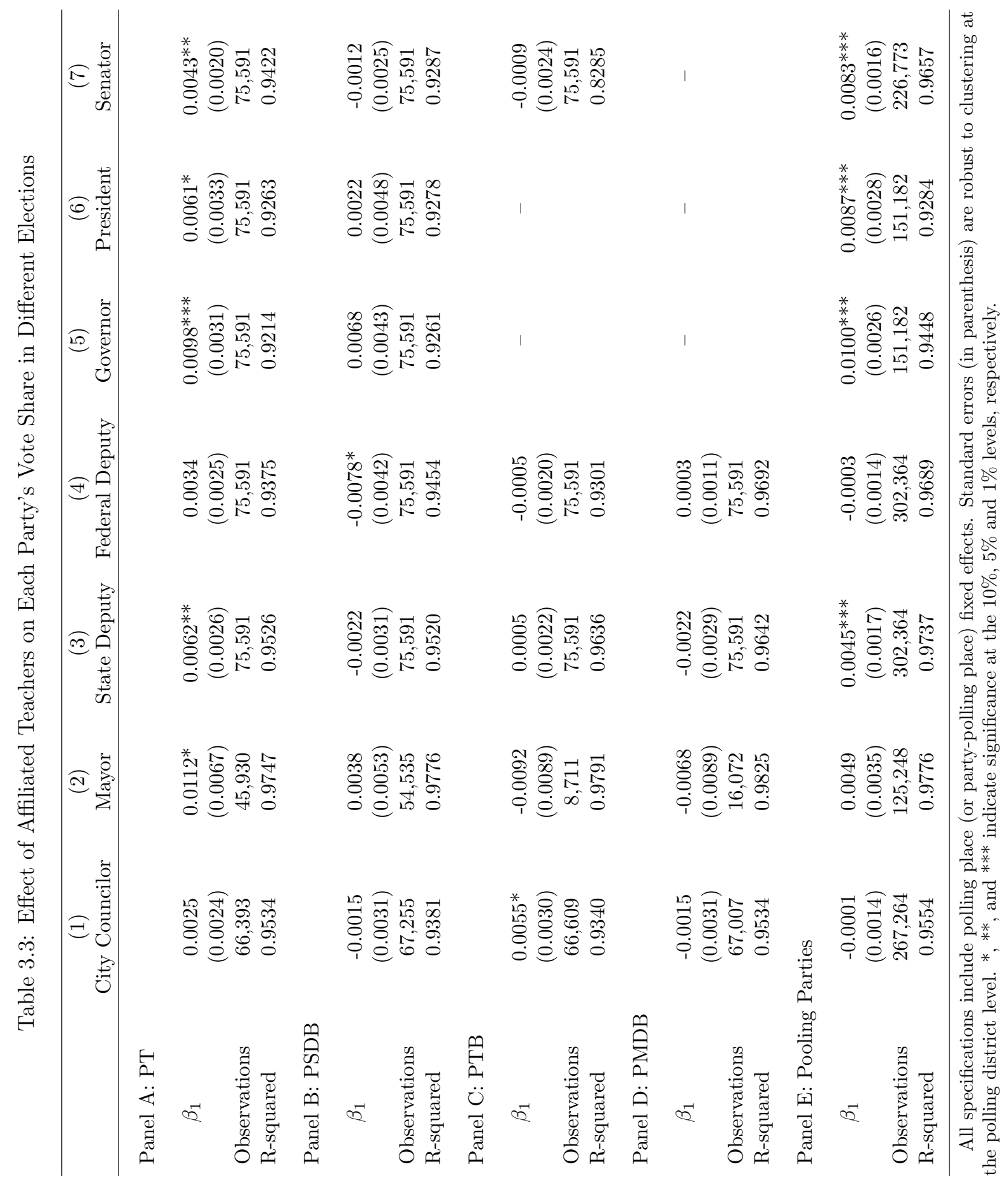


a result of the interaction with voting-aged high school students.

The contrast between the magnitude of the estimates obtained for elections under plurality rules and those for elections under a proportional representation system goes in line with the possibility that teachers opt to configure their propaganda in order to praise not their party as a whole, but rather the figure of specific candidates. Arguably, this kind of behavior would surely be harder in the occasions where multiple candidates from a single party could run for the same office, such as elections under proportional representation systems (but not those under plurality rules).

However, as indicated by the inspection of Panels A-D, we remark that the results found by using the pooling sample are possibly (entirely) driven by the corresponding results verified for the PT (Panel A), ${ }^{18}$ since the related estimates for the other three parties are usually statistically insignificant. This observation might suggest that the PT is somehow more capable or more effective than other parties in motivating their affiliated advocates towards engaging in partisan propaganda. Alternatively, it is possible that public manifestations of identification with some political ideologies are more easily conducted (and tolerated) than the defense of others. For instance, teachers affiliated to more rightist parties may be related to insignificant effects as a result of the tendency verified in Brazil since the late 1980s - and nicknamed direita envergonhada, or embarrassed right - consisting of a certain reluctance or even shame by right-wing politicians as well as their voters to openly state their political positions and to be ideologically labeled as conservatives. ${ }^{19}$ As some authors have argued, this event is most likely reinforced by the link between rightist ideologies and the legacy of the Brazilian military dictatorship of 1964-1985 (Pierucci (1987); Power and Zucco (2012)). Hence, it is possible that our results are stronger for the $\mathrm{PT}$ as a consequence of that party being arguably the leftmost one among the four parties considered. ${ }^{20}$

\footnotetext{
${ }^{18}$ This event is most likely to be true for the elections of governor, president, and senator, which were not disputed by all four considered parties.

${ }^{19}$ See, for instance, Pierucci (1987), Rodrigues (1987) and Power (2000). Power (2000) states in particular that a common political marketing strategy followed by candidates of conservative parties is to omit their party label from their campaign advertising.

${ }^{20}$ Power and Zucco (2012) develop a continuous ideology index that places Brazilian political parties in a left-right political spectrum. Their measure is constructed from survey responses of almost eight hundred federal legislators from 1990 to 2009 and ranks parties in a scale from one to ten, with larger numbers being associated with right-wing ideologies. These authors argue that, for instance, more rightist positions in their scale are associated with a higher propensity to display more promarket economic preferences and to support the armed forces' right to intervene in order to guarantee internal order. Their index assumes the value of 3.08 for the PT, 5.56 for the PMDB, 5.65 for the PSDB, and 6.43 for the PTB.
} 


\subsection{Further Exercises}

\subsubsection{Robustness Checks}

While the results presented in the last section are aligned with our hypothesis of partisan indoctrination in the classroom, they are also coherent with alternative explanations. In particular, our estimates may be driven by the influence that teachers might present on different but correlated audiences, under the condition of mere party-affiliated individuals outside the classroom environment (i.e. without employing their teacher status to broaden their audience) and thus be affected by an omitted variables problem.

In order to explore whether this is the case, we conduct an exercise similar to that presented above consisting of replacing the target group with a demographic group who is far less likely to interact with high school teachers (at least in a teacher-pupil relationship). Namely, we consider voters aged 16-17 who either had not initiated basic education, or who had already completed high school at the time of electoral registration (this group will henceforth be referred to as the "placebo group"). Specifically, we reestimate models (3.2) and (3.3) after replacing target_group $p_{s, d}$ with the share of voters in station $s$ (in polling district $d$ ) belonging to that placebo group (denoted placebo_group ${ }_{s, d}$ ).

The particular choice for voters aged $16-17$ is made for two main reasons. First, as previously stated, considering such an age cohort allows us to avoid imprecisions in voters' actual educational status at the time of election, as the corresponding voters are likely to have just registered for voting. Thus, voters aged 16-17 who are indicated by their electoral registers not to be enrolled in high school are expected to effectively be in that situation at the time of election. Also, should our previous estimates be driven by affiliated teachers influencing all voters aged 16-17 alike-i.e. regardless of being their high school students - we would expect to find estimates of a similar impact of those teachers on voting patterns of the placebo group. On the other hand, the absence of significant effects in that case could serve as further indication that our previously found evidence is indeed related to intraclassroom interactions between affiliated teachers and their pupils.

The corresponding results of that exercise are presented in Table 3.4. First, we observe that the estimates related to the PT and to the sample that pools the four considered parties (Panels A and E) are overall statistically insignificant, with the exception of the coefficients regarding the presidential election. Since these panels were the ones for which significant estimates were found in our main results, we gain further confidence on our 


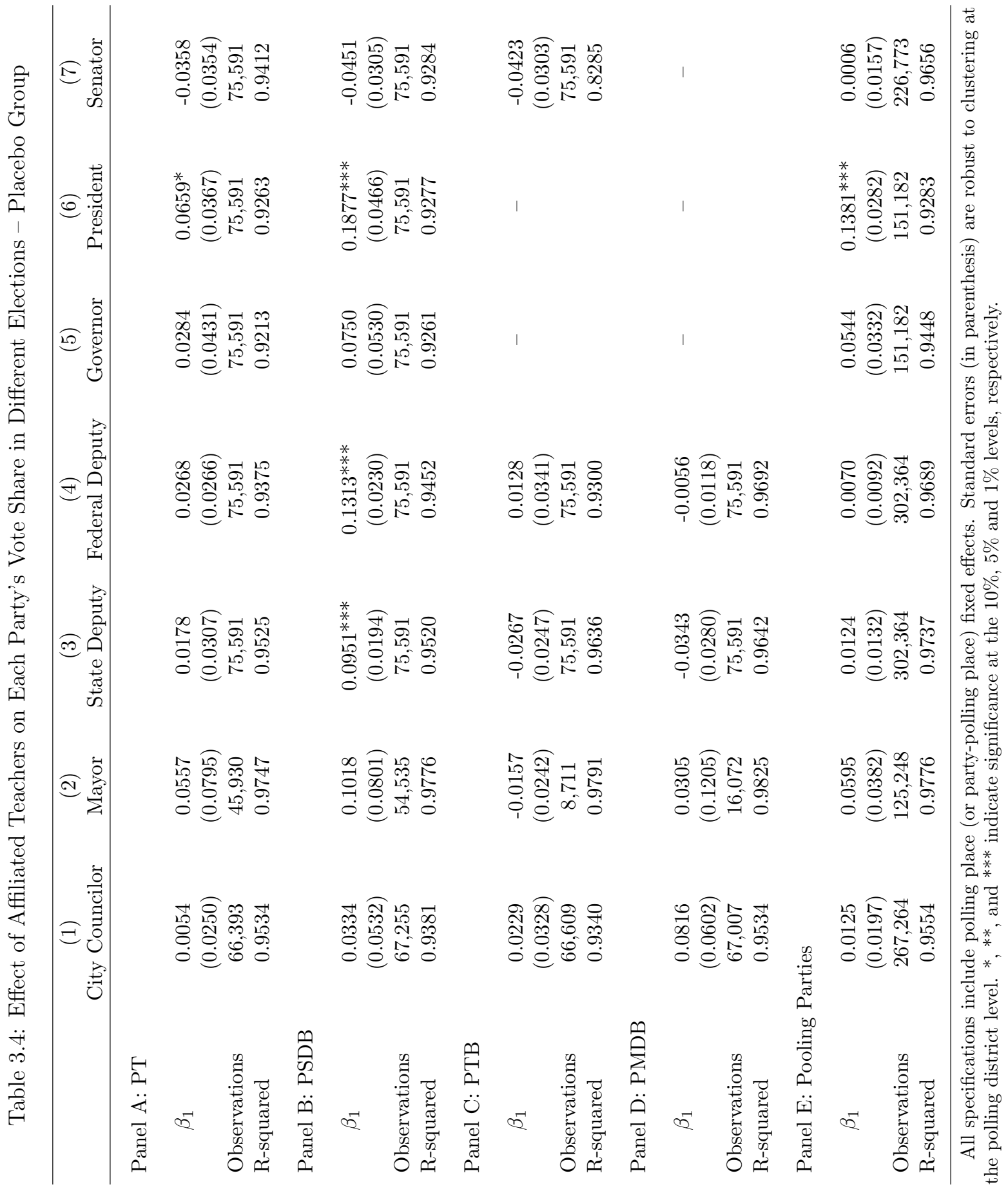


hypothesis of political indoctrination in the classroom. The same event (of statistical insignificance) applies to the coefficients related to the PTB (Panel C) and to the PMDB (Panel D). On the other hand, some statistically significant estimates are found regarding the electoral influence of teachers affiliated to the PSDB on the placebo group.

\subsubsection{Effects on Turnout}

Next, we proceed to exploring whether affiliated teachers have an impact on their pupils' electoral turnout. In other words, we would like to assess whether the positive influenceevidenced in Section 3.4 of such teachers on parties' vote shares specifically consists in convincing students who would otherwise not vote. In particular, confronting that hypothesis with the alternative possibility that the effect of affiliated teachers on vote shares is actually driven by shifting students' political preferences from one party to another could lead to a better understanding of the effectiveness of political indoctrination by teachers as well as of political participation among the young, for instance.

For each of the four considered parties and for each election year, we then estimate the model

$$
\begin{aligned}
\text { turnout }_{s, d}=\beta_{0} & +\beta_{1} \text { teachers_party }_{d} * \text { target_group }_{s, d}+\beta_{2} \text { target_group }_{s, d}+ \\
& +\gamma_{b}+\varepsilon_{s, d}
\end{aligned}
$$

where turnout $_{s, d}$ denotes the turnout rate (ranging from 0 to 100) at polling station $s$ in polling district $d$. Unlike the preceding regressions, however, in estimating model (3.4) we use observations on all polling stations (at the given election year) rather than only those on stations in administrative units (municipalities) wherein the given party effectively ran for election (and had a well defined vote share). As before, model (3.4) is also estimated by pooling observations on the four parties after replacing polling place fixed effects with party-polling place fixed effects.

The corresponding results are presented in Table 3.5. Panel A of that table presents estimates regarding the effect on turnout at the 2008 local elections, whereas Panel B considers turnout at the 2010 general elections. First, we observe from Panel A that the density of teachers affiliated to the PSDB or to the PTB has a positive effect (as a result of their interactions with voting-aged students) on turnout at local elections. For instance, the coefficient associated with the PTB indicates that, regarding a polling station wherein $20 \%$ of the voters belong to the target group, a share of 1 p.p. of teachers affiliated to that party is responsible for almost 0.3 p.p. of the turnout rate at such a 
polling station in 2008. However, as previously shown in Table 3.3, such an effect on turnout did not (significantly) translate into positive effects on these two parties' vote shares in the corresponding elections. Similarly, despite having presented a significant impact on vote shares, teacher affiliation to the PT is not suggested to influence student turnout. Thus, for that party it may be the case that affiliated teachers are actually able to change the political leanings of students who would vote for another party. On the other hand, the estimates associated with turnout at the 2010 general elections are overall statistically insignificant. An exception is made for the coefficient related to the PMDB, which is negative and significant at the $10 \%$ level. We conjecture, though, that the significance of that coefficient may be related to the fact that there was no candidate running under the PMDB for the positions of governor, senator, or president in 2010.

Table 3.5: Effect of Affiliated Teachers on Voter Turnout

\begin{tabular}{cccccc}
\hline \multicolumn{1}{c}{$(1)$} & $(2)$ & $(3)$ & $(4)$ & $(5)$ \\
PT & PSDB & PTB & PMDB & Pooling \\
\hline \multirow{2}{*}{ Panel A: 2008 Local Elections } & & & & \\
\multicolumn{1}{c}{$\beta_{1}$} & -0.0036 & $0.0087^{* *}$ & $0.0144^{* *}$ & 0.0002 & $0.0033^{*}$ \\
& $(0.0038)$ & $(0.0036)$ & $(0.0058)$ & $(0.0048)$ & $(0.0019)$ \\
Observations & 67,355 & 67,355 & 67,355 & 67,355 & 269,420 \\
R-squared & 0.6866 & 0.6867 & 0.6867 & 0.6866 & 0.6866
\end{tabular}

Panel B: 2010 General Elections

\begin{tabular}{cccccc}
\multicolumn{1}{c}{$\beta_{1}$} & -0.0059 & -0.0060 & -0.0100 & $-0.0092^{*}$ & $-0.0065^{* *}$ \\
& $(0.0052)$ & $(0.0062)$ & $(0.0079)$ & $(0.0050)$ & $(0.0028)$ \\
Observations & 75,591 & 75,591 & 75,591 & 75,591 & 302,364 \\
R-squared & 0.6608 & 0.6608 & 0.6608 & 0.6608 & 0.6608
\end{tabular}

All specifications include polling place (or party-polling place) fixed effects. Standard errors (in parenthesis) are robust to clustering at the polling district level. ${ }^{*},{ }^{* *}$, and ${ }^{* * *}$ indicate significance at the $10 \%, 5 \%$ and $1 \%$ levels, respectively.

\subsection{Conclusion}

In this chapter we investigate the influence that politically active teachers may present in the electoral process through shaping their students' voting behavior by means of partisan propaganda in the classroom environment. This analysis is achieved by exploiting very rich databases on public high school teachers and on party-affiliated voters - through which we are able to identify those teachers' political affiliations - and by considering the relationship between the density of affiliated teachers and electoral outcomes for the corresponding party in a given region. 
To overcome the matter of selection in the assignment of teachers to schools and of voters to polling places (which would likely bias our estimates), we exploit variation in the intensity of the hypothesized effect according to characteristics of the electorate at a level (polling stations) into which, arguably, neither teachers nor voters are able to select themselves.

We find evidence that is consistent with our hypothesis of political indoctrination in the classroom, and the related effect of the presence of party-affiliated teachers on a party's vote share seems to be more pronounced for elections based on plurality voting systems. However, we find that such an effect is apparently driven by teachers affiliated to the Workers' Party. In addition, such teachers do not appear to have an effect on electoral turnout by their students, so their impact on vote shares is suggested to take place through altering the political leanings of students who would turn out to vote regardless of their interference.

Our results indicating that party-affiliated teachers may play such a role raise very important questions, especially regarding what kind of teaching is ultimately being performed in their classes, and whether the suggested diversion from curriculum content standards is deleterious to educational outcomes of their students. In this sense, it would be worthwhile to also investigate whether teachers of certain subjects have relatively more leeway to define their courses' contents (and their ways of presenting them), and thus a greater ability to influence electoral outcomes. Moreover, another interesting topic concerns the reasons why teachers would be engaging in that kind of behavior, and particularly whether party-affiliated teachers are being paid to politically influence their pupils. Such questions are left as agenda for future research.

\section{References for Chapter 3}

Card, David (1992). "Using Regional Variation in Wages to Measure the Effects of the Federal Minimum Wage". Industrial and Labor Relations Review, 46(1), pp. 22-37.

Corrales, Javier (2006). "Political Obstacles to Expanding and Improving Schooling in

Developing Countries". In: Educating All Children: A Global Agenda. Ed. by Joel E. Cohen, David Bloom, and Martin B. Malin. Cambridge: The MIT Press.

Dee, Thomas S. (2004). "Are There Civic Returns to Education?" Journal of Public Economics, 88(9), pp. 1697-1720.

Duflo, Esther (2001). "Schooling and Labor Market Consequences of School Construction in Indonesia: Evidence from an Unusual Policy Experiment". American Economic Review, 91(4), pp. 1-60. 
Eberts, Randall W. and Joe A. Stone (1987). "Teacher Unions and the Productivity of Public Schools". Industrial and Labor Relations Review, 40(3), pp. 354-363.

Finan, Frederico (2005). "Political Patronage and Local Development: A Brazilian Case Study". Working Paper.

Ginsburg, Mark B., Sangeeta Kamat, Rajeshwari Raghu, and John Weaver (1992). "Educators/politics". Comparative Education Review, pp. 417-445.

Hahn, Carole (1998). Becoming Political: Comparative Perspectives on Citizenship Education. Suny Press.

Hanushek, Eric (2002). "Publicly Provided Education". In: Handbook of Public Economics, Volume 4. Ed. by Alan J. Auerbach and Martin Feldstein. Amsterdam: North-Holland.

Hillygus, D. Sunshine (2005). "The Missing Link: Exploring the Relationship between Higher Education and Political Engagement". Political Behavior, 27(1), pp. 25-47.

Horowitz, David (2006). The Professors: The 101 Most Dangerous Academics in America. Regnery Publishing.

Hoxby, Caroline M. (1996). "How Teachers' Unions Affect Education Production". Quarterly Journal of Economics, 111(3), pp. 671-718.

Kam, Cindy D. and Carl L. Palmer (2008). "Reconsidering the Effects of Education on Political Participation". The Journal of Politics, 70(3), pp. 612-631.

Kitschelt, Herbert and Steven I. Wilkinson (2007). Patrons, Clients and Policies: Patterns of Democratic Accountability and Political Competition. Cambridge University Press.

Larreguy, Horacio (2013). "Monitoring Political Brokers: Evidence from Clientelistic Networks in México". Working Paper.

Mainwaring, Scott (1999). Rethinking Party Systems in the Third Wave of Democratization: The Case of Brazil. Stanford University Press.

Milligan, Kevin, Enrico Moretti, and Philip Oreopoulos (2004). "Does Education Improve Citizenship? Evidence from the United States and the United Kingdom". Journal of Public Economics, 88(9), pp. 1667-1695.

Moe, Terry M. (2011). Special Interest: Teachers Unions and America's Public Schools. Brookings Institution Press.

Myers, John P. (2007). "Citizenship Education Practices of Politically Active Teachers in Porto Alegre, Brazil and Toronto, Canada". Comparative Education Review, 51(1), pp. $1-24$.

Nie, Norman, Jane Junn, and Ken Stehlik-Barry (1996). Education and Citizenship in America. Chicago: Cambridge University Press.

Persson, Mikael (2014). "Testing the Relationship Between Education and Political Participation Using the 1970 British Cohort Study". Political Behavior, 36(4), pp. 877897.

Pierucci, Antônio F. (1987). "As Bases da Nova Direita". Novos Estudos Cebrap, 19, pp. $26-45$. 
Power, Timothy J. (2000). The Political Right in Postauthoritarian Brazil: Elites, Institutions, and Democratization. University Park: The Pennsylvania State University Press.

Power, Timothy J. and Cesar Zucco (2012). "Elite Preferences in a Consolidating Democracy: the Brazilian Legislative Surveys, 1990-2009". Latin American Politics and Society, 54(4), pp. 1-27.

Rockoff, Jonah E. (2004). "The Impact of Individual Teachers on Student Achievement: Evidence from Panel Data". American Economic Review, 94(2), pp. 247-252.

Rodrigues, Leôncio M. (1987). Quem é Quem na Constituinte: uma Análise Sócio-política dos Partidos e Deputados. São Paulo: OESP.

Schaffer, Frederic Charles (2007). Elections for Sale: the Causes and Consequences of Vote Buying. Lynne Rienner Publishers.

Schugurensky, Daniel and John Myers (2003). "A Framework to Explore Lifelong Learning: The Case of the Civic Education of Civics Teachers". International Journal of Lifelong Education, 22(4), pp. 325-352.

Solis, Alex (2014). "Does higher education cause political participation? Evidence from a regression discontinuity design". Working Paper.

Westheimer, Joel and Joseph Kahne (2004). "What Kind of Citizen? The Politics of Educating for Democracy". American Educational Research Journal, 41(2), pp. 237269.

Wolfinger, Raymond E. and Steven J. Rosenstone (1980). Who votes? New Haven: Yale University Press. 


\section{Appendices to Chapter 3}

\section{A Additional Tables}

Table 3.A1: Distribution of TSE Districts across Municipalities

\begin{tabular}{ccc}
\hline $\begin{array}{c}\text { Number of Districts within } \\
\text { the Municipality }\end{array}$ & $\begin{array}{c}\text { Number of } \\
\text { Municipalities }\end{array}$ & $\begin{array}{c}\text { Frequence } \\
(\%)\end{array}$ \\
\hline 1 & 600 & 93.02 \\
2 & 31 & 4.81 \\
3 & 3 & 0.47 \\
4 & 3 & 0.47 \\
6 & 3 & 0.47 \\
7 & 3 & 0.47 \\
10 & 1 & 0.16 \\
58 & 1 & 0.16 \\
\hline Total & 645 & 100.00 \\
\hline
\end{tabular}

Table 3.A2: Distribution of Municipalities across TSE Districts

\begin{tabular}{ccc}
\hline $\begin{array}{c}\text { Number of Municipalities within } \\
\text { the TSE District }\end{array}$ & $\begin{array}{c}\text { Number of } \\
\text { Districts }\end{array}$ & $\begin{array}{c}\text { Frequence } \\
(\%)\end{array}$ \\
\hline 1 & 243 & 57.45 \\
2 & 83 & 19.62 \\
3 & 53 & 12.53 \\
4 & 20 & 4.73 \\
5 & 9 & 2.13 \\
6 & 11 & 2.60 \\
7 & 3 & 0.71 \\
10 & 1 & 0.24 \\
\hline Total & 423 & 100.00 \\
\hline
\end{tabular}


Table 3.A3: Summary Statistics by Estimating Sample - 1/3

\begin{tabular}{lccccc}
\hline \multirow{2}{*}{ Variable } & \multicolumn{5}{c}{ Mean [Std. Deviation] } \\
\cline { 2 - 6 } & $\begin{array}{c}\text { PT } \\
\text { Sample }\end{array}$ & $\begin{array}{c}\text { PSDB } \\
\text { Sample }\end{array}$ & $\begin{array}{c}\text { PTB } \\
\text { Sample }\end{array}$ & $\begin{array}{c}\text { PMDB } \\
\text { Sample }\end{array}$ & $\begin{array}{c}\text { Pooling } \\
\text { Sample }\end{array}$ \\
\hline Panel A: Elections for City Councilor & & & & \\
teachers_partyd & 1.9347 & 0.9697 & 0.6715 & 0.5815 & 1.0378 \\
& {$[1.5074]$} & {$[1.2972]$} & {$[0.9585]$} & {$[0.9784]$} & {$[1.3205]$} \\
target_group $_{s, d}$ & 1.3959 & 1.4078 & 1.3988 & 1.4049 & 1.4019 \\
& {$[3.8973]$} & {$[3.9128]$} & {$[3.896]$} & {$[3.913]$} & {$[3.9048]$} \\
placebo_group $_{s, d}$ & 0.0582 & 0.0583 & 0.0581 & 0.0581 & 0.0582 \\
& {$[0.2660]$} & {$[0.2654]$} & {$[0.2655]$} & {$[0.2652]$} & {$[0.2655]$} \\
vote_share $_{s, d}$ & 12.7132 & 14.4371 & 6.3203 & 6.8052 & 10.0725 \\
& {$[9.436]$} & {$[8.5969]$} & {$[5.7611]$} & {$[6.9614]$} & {$[8.5935]$}
\end{tabular}

Panel B: Elections for Mayor

$\begin{array}{lccccc}\text { teachers_party }_{d} & 2.0944 & 0.9133 & 0.6290 & 0.7462 & 1.3052 \\ & {[1.3282]} & {[1.2308]} & {[1.2728]} & {[1.4334]} & {[1.4318]} \\ \text { target_group }_{s, d} & 1.2376 & 1.3446 & 1.7143 & 1.5614 & 1.3589 \\ & {[3.6374]} & {[3.8119]} & {[4.4341]} & {[4.1125]} & {[3.8387]} \\ \text { placebo_group }_{s, d} & 0.0532 & 0.0573 & 0.0685 & 0.0620 & 0.0572 \\ & {[0.2525]} & {[0.2646]} & {[0.3003]} & {[0.2766]} & {[0.2645]} \\ \text { vote_share }_{s, d} & 29.6034 & 27.5988 & 29.3473 & 32.1056 & 29.0338 \\ & {[18.0486]} & {[17.6398]} & {[19.0228]} & {[20.5789]} & {[18.3488]}\end{array}$

Panel C: Elections for State Deputy

\begin{tabular}{lccccc} 
teachers_party $_{d}$ & 2.0240 & 0.9424 & 0.6526 & 0.5759 & 1.0487 \\
& {$[1.6447]$} & {$[1.2298]$} & {$[0.9165]$} & {$[1.0000]$} & {$[1.3602]$} \\
target_group $_{s, d}$ & 1.2422 & 1.2422 & 1.2422 & 1.2422 & 1.2422 \\
& {$[3.4257]$} & {$[3.4257]$} & {$[3.4257]$} & {$[3.4257]$} & {$[3.4257]$} \\
placebo_group $_{s, d}$ & 0.0751 & 0.0751 & 0.0751 & 0.0751 & 0.0751 \\
& {$[0.4808]$} & {$[0.4808]$} & {$[0.4808]$} & {$[0.4808]$} & {$[0.4808]$} \\
vote_share $_{s, d}$ & 19.2301 & 20.5681 & 3.7573 & 4.5577 & 12.0283 \\
& {$[11.6853]$} & {$[11.5810]$} & {$[5.9013]$} & {$[6.5370]$} & {$[12.2192]$} \\
\hline
\end{tabular}


Table 3.A4: Summary Statistics by Estimating Sample $-2 / 3$

\begin{tabular}{lccccc}
\hline \multirow{2}{*}{ Variable } & \multicolumn{5}{c}{ Mean $[$ Std. Deviation] } \\
\cline { 2 - 6 } & $\begin{array}{c}\text { PT } \\
\text { Sample }\end{array}$ & $\begin{array}{c}\text { PSDB } \\
\text { Sample }\end{array}$ & $\begin{array}{c}\text { PTB } \\
\text { Sample }\end{array}$ & $\begin{array}{c}\text { PMDB } \\
\text { Sample }\end{array}$ & $\begin{array}{c}\text { Pooling } \\
\text { Sample }\end{array}$ \\
\hline Panel D: Elections for Federal Deputy & & & & \\
teachers_party & & & & & \\
& 2.0240 & 0.9424 & 0.6526 & 0.5759 & 1.0487 \\
target_group $_{s, d}$ & {$[1.6447]$} & {$[1.2298]$} & {$[0.9165]$} & {$[1.0000]$} & {$[1.3602]$} \\
& 1.2422 & 1.2422 & 1.2422 & 1.2422 & 1.2422 \\
placebo_group $_{s, d}$ & {$[3.4257]$} & {$[3.4257]$} & {$[3.4257]$} & {$[3.4257]$} & {$[3.4257]$} \\
& 0.0751 & 0.0751 & 0.0751 & 0.0751 & 0.0751 \\
vote_share $_{s, d}$ & {$[0.4808]$} & {$[0.4808]$} & {$[0.4808]$} & {$[0.4808]$} & {$[0.4808]$} \\
& 16.3167 & 16.2179 & 2.7722 & 2.0545 & 9.3403 \\
& {$[9.7816]$} & {$[10.1069]$} & {$[3.7867]$} & {$[4.6703]$} & {$[10.3220]$}
\end{tabular}

Panel E: Elections for Governor

$\begin{array}{lccccc}\text { teachers_party }_{d} & 2.0240 & 0.9424 & - & - & 1.4832 \\ & {[1.6447]} & {[1.2298]} & & {[1.5496]} \\ \text { target_group }_{s, d} & 1.2422 & 1.2422 & - & - & 1.2422 \\ & {[3.4257]} & {[3.4257]} & & & {[3.4257]} \\ \text { placebo_group }_{s, d} & 0.0751 & 0.0751 & - & - & 0.0751 \\ & {[0.4808]} & {[0.4808]} & & & {[0.4808]} \\ \text { vote_share }_{s, d} & 31.5339 & 45.939 & - & - & 38.7365 \\ & {[11.1309]} & {[12.2659]} & & & {[13.7496]}\end{array}$

Panel F: Elections for President

\begin{tabular}{|c|c|c|c|c|c|}
\hline teachers_party & $\begin{array}{c}2.0240 \\
{[1.6447]}\end{array}$ & $\begin{array}{c}0.9424 \\
{[1.2298]}\end{array}$ & - & - & $\begin{array}{c}1.4832 \\
{[1.5496]}\end{array}$ \\
\hline target_group $_{s, d}$ & $\begin{array}{c}1.2422 \\
{[3.4257]}\end{array}$ & $\begin{array}{c}1.2422 \\
{[3.4257]}\end{array}$ & - & - & $\begin{array}{c}1.2422 \\
{[3.4257]}\end{array}$ \\
\hline placebo_group $p_{s, d}$ & $\begin{array}{c}0.0751 \\
{[0.4808]}\end{array}$ & $\begin{array}{c}0.0751 \\
{[0.4808]}\end{array}$ & - & - & $\begin{array}{c}0.0751 \\
{[0.4808]}\end{array}$ \\
\hline vote_share $_{s, d}$ & $\begin{array}{c}34.5432 \\
{[12.3332]}\end{array}$ & $\begin{array}{c}37.9579 \\
{[12.5190]}\end{array}$ & - & - & $\begin{array}{c}36.2506 \\
{[12.5431]}\end{array}$ \\
\hline
\end{tabular}


Table 3.A5: Summary Statistics by Estimating Sample $-3 / 3$

\begin{tabular}{|c|c|c|c|c|c|}
\hline \multirow{3}{*}{ Variable } & \multicolumn{5}{|c|}{ Mean [Std. Deviation] } \\
\hline & $\mathrm{PT}$ & PSDB & PTB & PMDB & Pooling \\
\hline & Sample & Sample & Sample & Sample & Sample \\
\hline \multicolumn{6}{|c|}{ Panel G: Elections for Senator } \\
\hline teachers_party & $\begin{array}{c}2.0240 \\
{[1.6447]}\end{array}$ & $\begin{array}{c}0.9424 \\
{[1.2298]}\end{array}$ & $\begin{array}{c}0.6526 \\
{[0.9165]}\end{array}$ & - & $\begin{array}{c}1.2063 \\
{[1.4262]}\end{array}$ \\
\hline target_group $_{s, d}$ & $\begin{array}{c}1.2422 \\
{[3.4257]}\end{array}$ & $\begin{array}{c}1.2422 \\
{[3.4257]}\end{array}$ & $\begin{array}{c}1.2422 \\
{[3.4257]}\end{array}$ & - & $\begin{array}{c}1.2422 \\
{[3.4257]}\end{array}$ \\
\hline placebo_group $_{s, d}$ & $\begin{array}{c}0.0751 \\
{[0.4808]}\end{array}$ & $\begin{array}{c}0.0751 \\
{[0.4808]}\end{array}$ & $\begin{array}{c}0.0751 \\
{[0.4808]}\end{array}$ & - & $\begin{array}{c}0.0751 \\
{[0.4808]}\end{array}$ \\
\hline vote_share $_{s, d}$ & $\begin{array}{l}16.4460 \\
{[6.5094]}\end{array}$ & $\begin{array}{l}22.2648 \\
{[6.3309]}\end{array}$ & $\begin{array}{c}7.9145 \\
{[2.7782]}\end{array}$ & - & $\begin{array}{l}15.5418 \\
{[8.0491]}\end{array}$ \\
\hline
\end{tabular}

Panel H: 2008 Local Elections

$\begin{array}{lccccc}\text { teachers_party }_{d} & 1.9211 & 0.9691 & 0.6683 & 0.5785 & 1.0342 \\ & {[1.5334]} & {[1.2978]} & {[0.9609]} & {[0.9768]} & {[1.3271]} \\ \text { target_group }_{s, d} & 1.4097 & 1.4097 & 1.4097 & 1.4097 & 1.4097 \\ & {[3.9190]} & {[3.9190]} & {[3.9190]} & {[3.9190]} & {[3.9190]} \\ \text { turnout }_{s, d} & 85.2729 & 85.2729 & 85.2729 & 85.2729 & 85.2729 \\ & {[4.5062]} & {[4.5062]} & {[4.5062]} & {[4.5062]} & {[4.5062]}\end{array}$

Panel I: 2010 General Elections

$\begin{array}{lccccc}\text { teachers_party }_{d} & 2.0240 & 0.9424 & 0.6526 & 0.5759 & 1.0487 \\ & {[1.6447]} & {[1.2298]} & {[0.9165]} & {[1.0000]} & {[1.3602]} \\ \text { target_group }_{s, d} & 1.2422 & 1.2422 & 1.2422 & 1.2422 & 1.2422 \\ & {[3.4257]} & {[3.4257]} & {[3.4257]} & {[3.4257]} & {[3.4257]} \\ \text { turnout }_{s, d} & 83.6163 & 83.6163 & 83.6163 & 83.6163 & 83.6163 \\ & {[5.2672]} & {[5.2672]} & {[5.2672]} & {[5.2672]} & {[5.2672]}\end{array}$




\section{B Additional Figures}

Figure 3.B1: Municipalities in the State of São Paulo. Highlighted: City of São Paulo

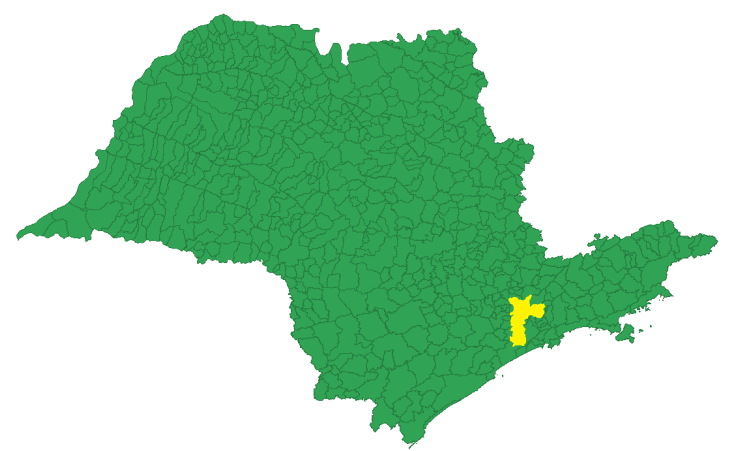

Figure 3.B2: Polling Districts in the City of São Paulo

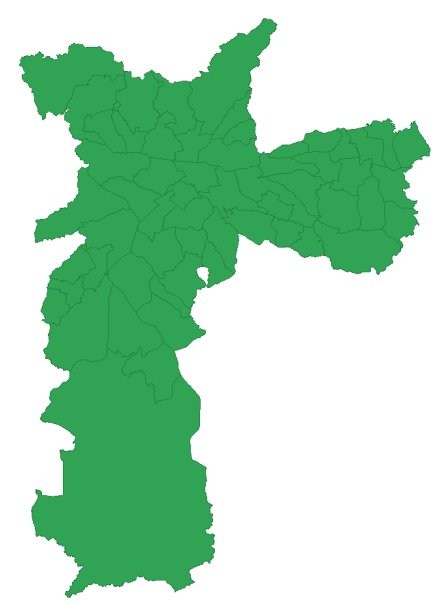


Figure 3.B3: A Public School Employed as a Polling Place

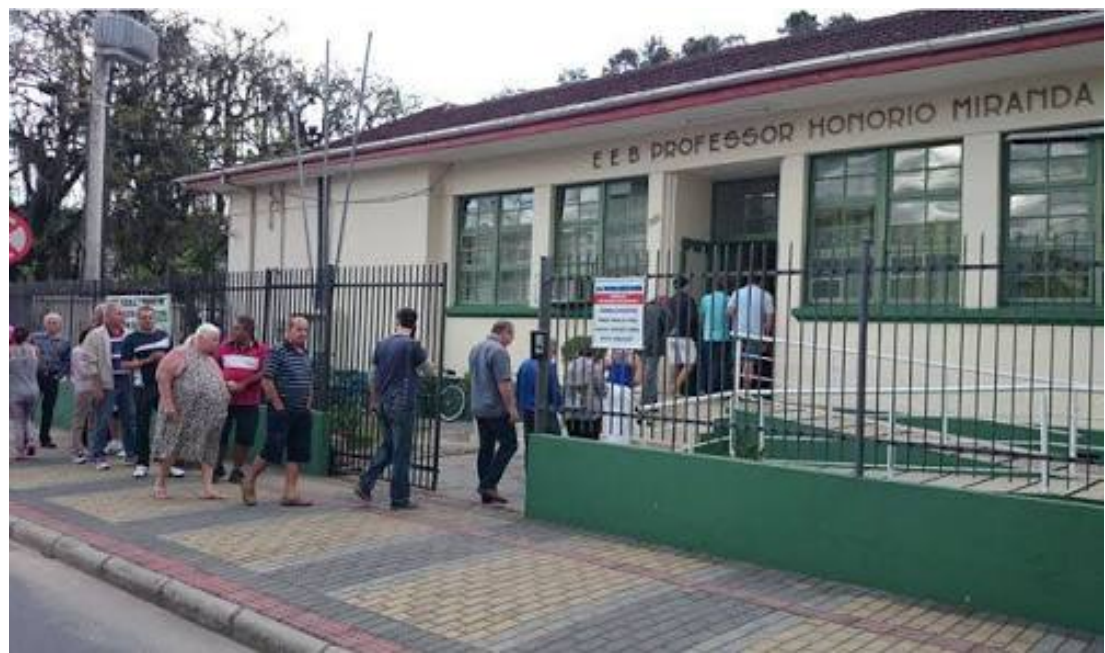

Source: Jornal Cruzeiro do Vale. Available at http://www.cruzeirodovale.com.br/geral/eleicoes-2014-confira-os-eleitos-no-estado-desanta-catarina.

Figure 3.B4: A Public School Classroom Used as a Polling Station

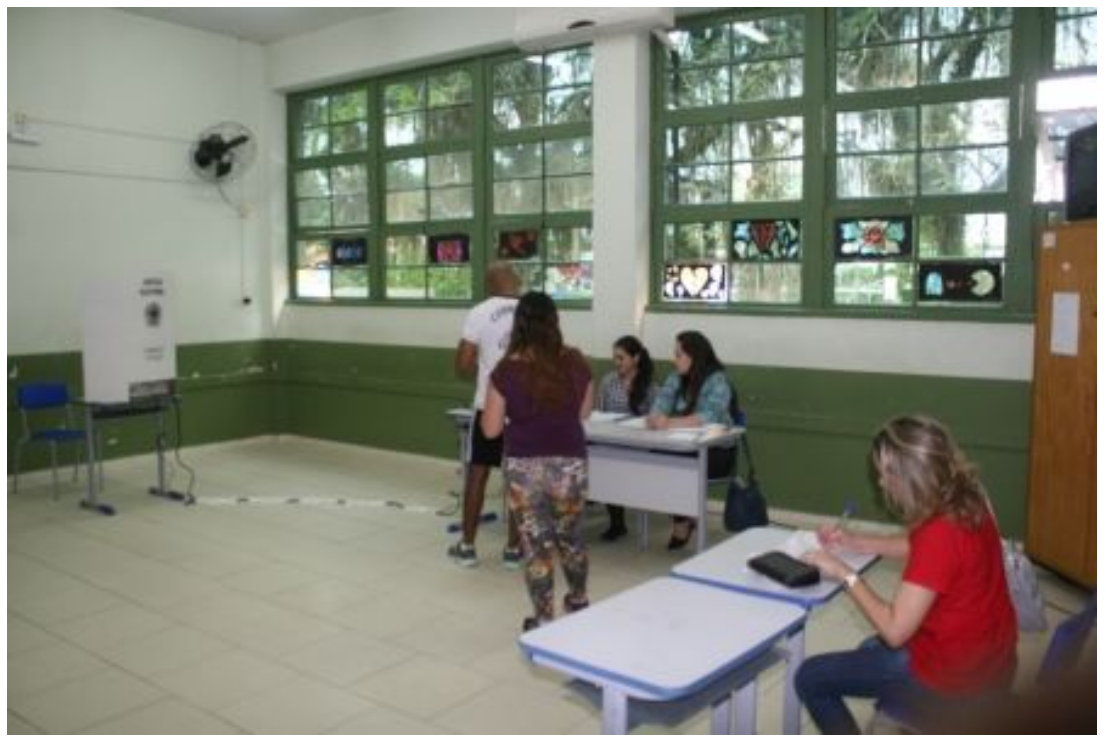

Source: Jornal Cruzeiro do Vale. Available at http://www.cruzeirodovale.com.br/geral/eleicoes-2014-confira-os-eleitos-no-estadode-santa-catarina. 